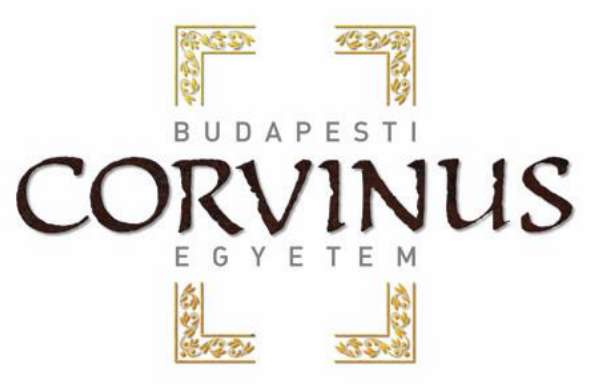

\title{
A klímaváltozás hatása Geometridae (Lepidoptera) fajok fenológiájára és populációdinamikájára
}

\author{
Doktori $(\mathrm{PhD})$ értekezés
}

Kúti Zsuzsanna 
A doktori iskola

megnevezése: Budapesti Corvinus Egyetem

Tájépítészeti és Tájökológiai Doktori Iskola

tudományága: $\quad$ Agrármüszaki

Vezetője: $\quad$ Csemez Attila, DSc

tanszékvezető egyetemi tanár

Budapesti Corvinus Egyetem

Tájtervezési és Területfejlesztési Tanszék

Témavezető: $\quad$ Ladányi Márta, PhD

egyetemi docens

Budapesti Corvinus Egyetem

Biometria és Agrárinformatikai Tanszék

A jelölt a Budapesti Corvinus Egyetem Doktori Szabályzatában előírt valamennyi feltételnek eleget tett, az értekezés mühelyvitájában elhangzott észrevételeket és javaslatokat az értekezés átdolgozásakor figyelembe vette, ezért az értekezés védési eljárásra bocsátható. 
A Budapesti Corvinus Egyetem Élettudományi Területi Doktori Tanácsának 2014. év március 18-i határozatában a nyilvános vita lefolytatására az alábbi bíráló bizottságot jelölte ki:

BÍRÁLÓ BIZOTTSÁG:

Elnöke

Bozó László, CSc MHAS

Tagjai

Erdélyi Éva, PhD

Drégelyi-Kiss Ágota, PhD

Hőhn Mária, CSc

Czúcz Bálint, PhD

Opponensek

Markó Viktor, PhD

Mika János, DSc

Titkár

Bodor Péter, PhD 


\section{TARTALOMJEGYZÉK}

1. BEVEZETÉS .5

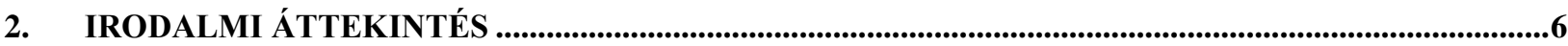

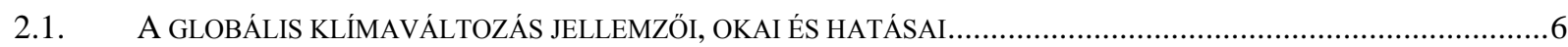

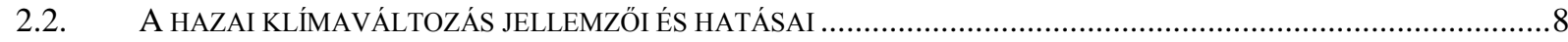

2.3. A GLOBÁLIS KLÍMAVÁLTOZÁS HATÁSA A TERMÉSZETES ÖKOSZISZTÉMÁKRA ........................................10

2.3.1. A globális klímaváltozás hatása a rovarokra ..............................................................................11

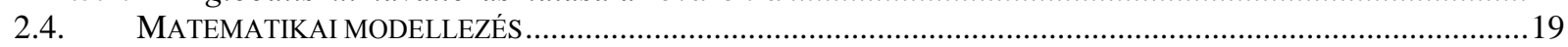

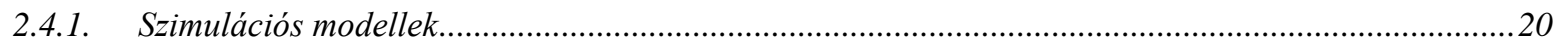

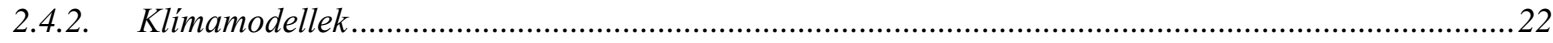

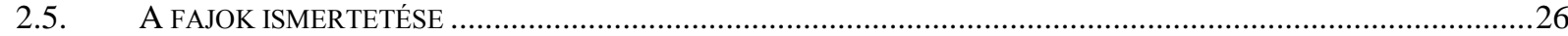

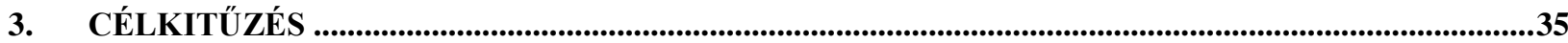

4. ANYAG ÉS MÓDSZEREK

4.1. A VIZSGÁLAT ANYAGA

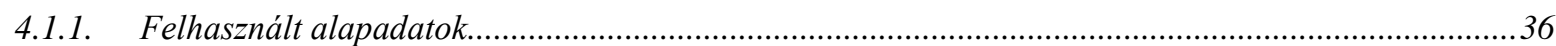

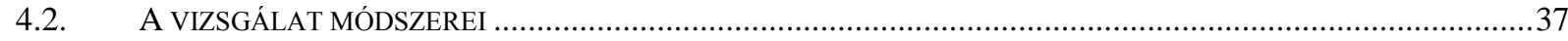

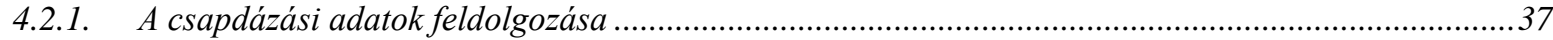

4.2.2. A rajzáskezdet és a rajzáshossz egymástól és a klimatikus viszonyoktól való függéseinek vizsgálata 38

4.2.3. Differenciaegyenleten és indikátoranalízisen alapuló populációdinamikai modellezés.......................38

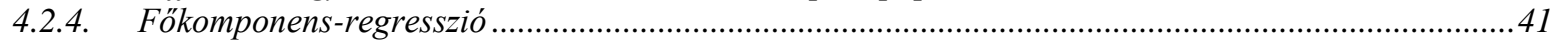

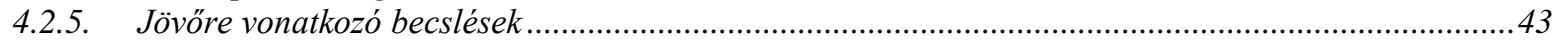

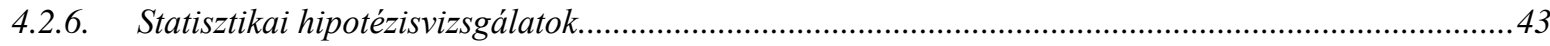

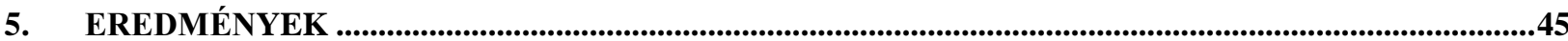

5.1. A RAJZÁSKEZDET ÉS A RAJZÁSHOSSZ EGYMÁSTÓL, VALAMINT A KLIMATIKUS VISZONYOKTÓL VALÓ

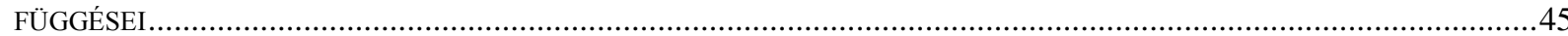

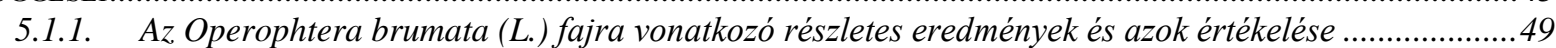

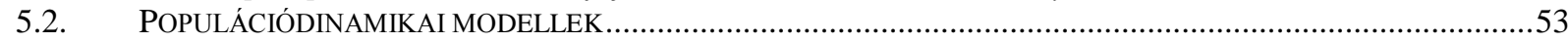

5.2.1. Differenciaegyenleten és indikátoranalizisen alapuló populációdinamikai modellek ........................53

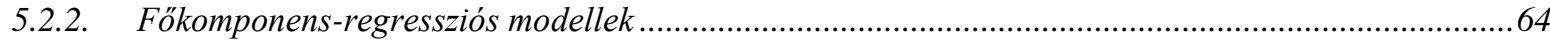

5.3. A KLIMATIKUS INDIKÁTOROKNAK A REGCM3.1 REGIONÁLIS KLÍMAMODELL BECSLÉSEI ALAPJÁN ELŐÁLLÍTOTT ÉRTÉKEI ÉS A LEPKÉK MEGFIGYELT ÉS A MODELLEK ÁLTAL BECSÜLT EGYEDSZÁMAINAK ÖSSZEVETÉSE

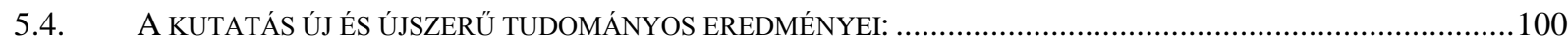

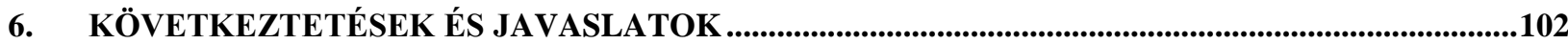

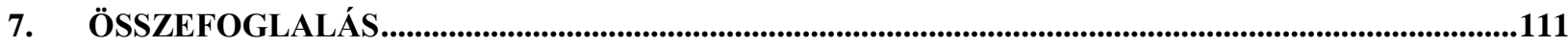

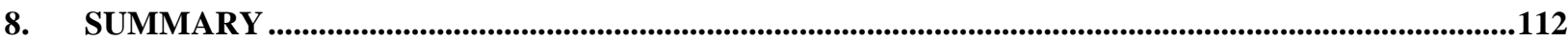

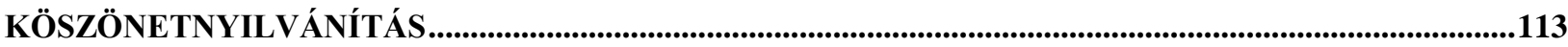

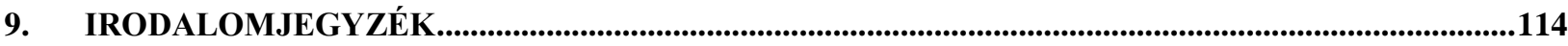

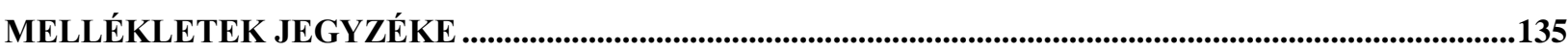

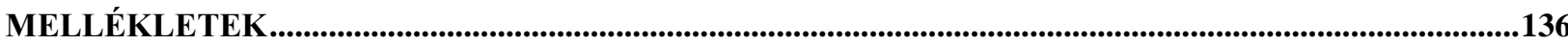




\section{BEVEZETÉS}

A téma aktualitása, jelentősége

$\mathrm{Az}$ ismert élőlényfajok több mint háromnegyedét gerinctelen állatfajok, többségükben rovarok és más ízeltlábúak alkotják. A gerinctelen élőlényközösségek szerepe azonban nemcsak bolygónk biodiverzitásában ilyen kiemelkedő, hanem a természetközeli és mezőgazdasági ökoszisztémák müködését is alapvetően befolyásolják. E tekintetben elegendő a virágos növények megporzására, a kártevő rovarokra, a talaj folyamatait fenntartó ízeltlábúakra vagy a humán-, állat- és növényegészségügyi kórokozók vektoraira utalnunk.

A klíma változékonysága alapvető hatással van a rovaregyüttesek szerkezetére, a regionális faunák összetételére, és az egyes lokális élőhelyek (mikrohabitatok, biotópok) szezonális cönológiai állapotváltozásaira is. Az időjárás közvetlen hatását a fenológiai és populációdinamikai folyamatokon keresztül fejti ki, amely közvetve eredményezi az áreaviszonyok és a biodiverzitás átalakulását.

A gerinctelen életközösségek azonban nemcsak önmagukban fontosak, hanem (úgy a környezet- és természetvédelem, mint a mezőgazdaság tekintetében) a klímaváltozás hatásának hatékony indikátorai is, hiszen segítségükkel olyan információk birtokába jutunk, amelyek más módszerekkel esetleg nem, vagy nehezen közelíthetök meg.

A klimatikus igényekre, fenológiára és a klímaváltozás hatásaira vonatkozó vizsgálatokból olyan információkhoz juthatunk, amelyek részben a növényvédelem, illetve erdővédelem területén is hasznosíthatóak.

Az értekezésben tárgyalt fajok közül négyet sem nemzetközi, sem hazai kutatásokban nem vizsgáltak ilyen szempontból, faunisztikai adatokat tekintve is csak kevés információ van róluk. Ezek a fajok nem kártevők, de ezen fajok is növelik a magyar fauna sokféleségét. 


\section{IRODALMI ÁTTEKINTÉS}

\subsection{A globális klímaváltozás jellemzői, okai és hatásai}

A XXI. század legnagyobb kihívása a klímaváltozás. Ma már az nem vitatható, hogy bolygónk felszínközeli hőmérséklete, éghajlata változik. Ezt a tényt kutatási eredmények és megfigyelések is alátámasztják. Az Éghajlat-változási Kormányközi Testület (International Panel on Climate Change, IPCC) 2007-ben megjelent IV. jelentése szerint az ipari forradalom után, 1850 óta a Földön a globális átlaghőmérséklet $0,76^{\circ} \mathrm{C}$-kal növekedett. A felmelegedés nagyrészt antropogén eredetü, és a légköri üvegházhatású gázok feldúsulásának tudható be. Az üvegházhatás mechanizmusának módját már több mint másfél évszázaddal ezelőtt tudományosan leírták. A légkörrel foglalkozó tudósok már az 1860-as években felismerték a nyomgázok jelentős szerepét bolygónk - élővilágának megfelelő - klímájának alakításában. 1862-ben jelent meg John Tyndall cikke, amely elsőként szólt a vízgőznek a légkört melegítő hatásáról. Az üvegházhatás és a klímaváltozás közötti összefüggést elöször Svante A. Arrhenius jegyezte le, aki az 1896-ban készült tanulmányában a kőszén elégetése során megnövekedő szén-dioxid koncentráció várható légköri következményeit írta le (Pongrácz és Bartholy, 2010). 2007 februárjában az Éghajlat-változási Kormányközi Testület (IPCC) megerősítette, hogy a Föld ilyen mértékü hőmérséklet-emelkedése és a hozzá kapcsolódó klimatikus anomáliák részben az emberi tevékenység következményeként könyvelhetők el. A gyárak, erőmüvek, a különböző közlekedési eszközök rohamosan növekvő száma miatt az ipari forradalom óta egyre több üvegházhatású gáz jut a légkörbe, amelynek következtében az üvegházhatás fokozódott (Kertész, 2001, Fry, 2008).

A globális klímaváltozás végigkísérte a Föld történetét. A közelmúltban lezajlott folyamatok döntően eltérnek a természeti okokra visszavezethető változásoktól (Kertész, 2001). A légkör hővisszatartó munkáját, az üvegházhatást a szelektíven abszorbeáló üvegházgázok eredményezik. Az üvegházhatás nemcsak antropogén hatásra következik be, hanem elsősorban természetes eredetü, és valójában pozitív jelenség. Az üvegházhatás igen fontos a földi élet szempontjából, ugyanis bolygónk meglehetősen hűvös lenne e nélkül: az átlaghőmérséklet csak $-18^{\circ} \mathrm{C}$ volna, szemben a tényleges $+15^{\circ} \mathrm{C}$-kal (Mészáros, 1993).

A szén-dioxid a vízgőz után a második legfontosabb üvegházhatású gáz a légkörben. A légkörben fellelhető szén-dioxid mennyisége a földtörténet során nagymértékben változott. Az ipari forradalom előtt, a holocéntől a szén-dioxid koncentrációja 280 ppm alatt volt (Webb és Wigley, 1985), míg 1800-tól napjainkig meredeken növekedett 380 ppm-ig (1. ábra) (Siegenthaler et al., 2005, Prentice et al., 2001, FAO 2006). Az IPCC Negyedik Helyzetértékelő 
Jelentése (2007) a légköri szén-dioxid koncentrációt 2100-ra 540 és 970 ppm közé becsüli. A fosszilis tüzelőanyagok elégetése és az erdőirtások során légkörbe kerülő szén-dioxid mennyisége több mint amit ez idő alatt a bioszféra és az óceánok képesek felvenni. Ennek következtében a légkör szén-dioxid tartalma folyamatosan nő (2. ábra).

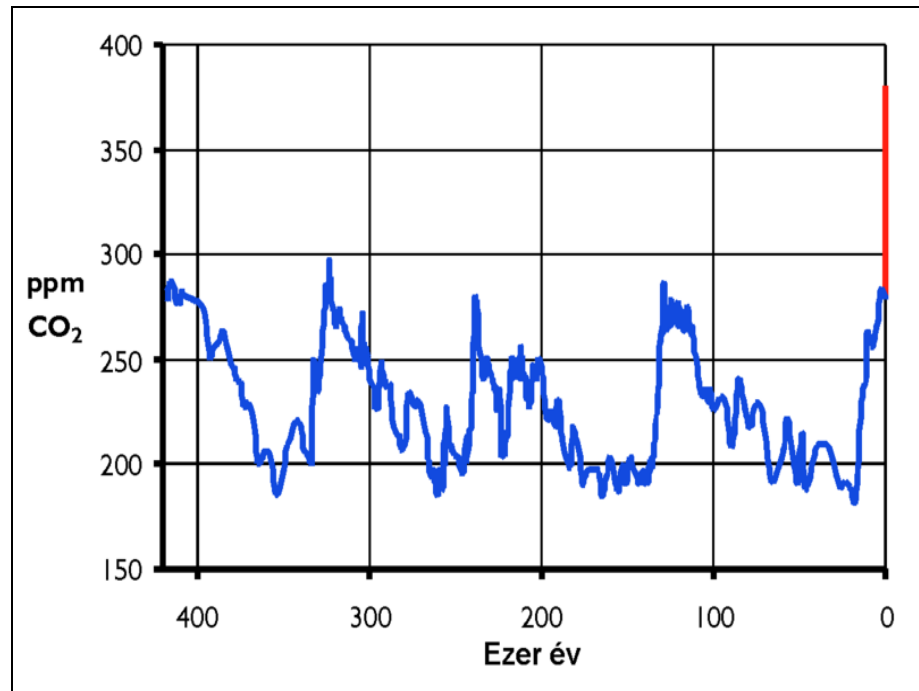

1. ábra A légköri szén-dioxid-koncentráció a múltban. A kék görbe mutatja, hogy 417000 év alatt soha nem lépte túl a légkör szén-dioxid-koncentrációja a 300 ppm értéket, azonban mint a görbe pirossal kiemelt szakaszán látszik, 1800-tól napjainkig meredeken növekedett 380 ppm-ig (FAO 2006)

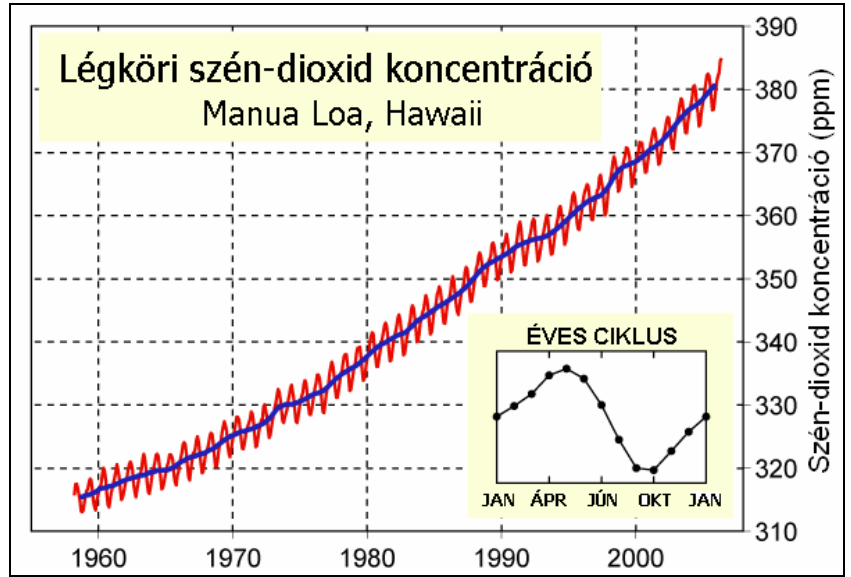

2. ábra $A$ légköri szén-dioxid-koncentrációt ábrázoló Keeling-görbe.

(Forrás: Mauna Loa Obszervatórium, Hawaii, NOAA (National Oceanic and Athmospheric Administration, USA) http://scrippsco2.ucsd.edu data/data.html, a magyar verziót Hornyák Sándor János szerkesztette)

A földi klíma tényleges változásának három oka van, amelyek valószínüleg egymással párhuzamosan hatnak: az éghajlati rendszer belső ingadozásai, természetes külső tényezök és az antropogén hatások (www.met.hu/eghajlat/eghajlatvaltozas/eghajlatvaltozas_okai).

Az klímaváltozás következtében a környezeti biotikus és abiotikus tényezők változnak, melyek következményei csak hosszútávon jelennek meg. A Föld óceánjainak magas hőkapacitásából fakadó kiegyenlítő hatása és más közvetítő folyamatok lassúsága miatt a Föld 
éghajlata lassan követi az azt módosító hatást. Emiatt még akkor is további melegedésre kell számítanunk, ha az üvegházhatású gázok koncentrációja tovább nem emelkedik (Meehl et al., 2005).

Feltételezések szerint a XIX. - XX. században megfigyelt egyre nagyobb mértékü felmelegedés a jégkorszakok közötti interglaciálisokkal magyarázható. Más elméletek szerint az emberi eredetü (antropogén) üvegházhatású gázok idézik elö, többek között a szén-dioxid, a metán, a dinitrogén-oxid stb. Milankovitch (1998) elmélete szerint a ciklikusan visszatérö glaciális időszakok alapvető okai a Föld pályájában 100 ezer év alatt bekövetkező változások. Ezen elmélet szerint jelenleg egy hosszúnak (100-150 ezer év) ígérkező interglaciális időszak elején tartunk (IPCC, 2007). A globális klímaváltozás folyamata igen nagy hatással lesz, és már van az egész bolygónkra, a minket közvetlenül és közvetve körülvevő világunkra, s ezen belül az emberi életre és az egészségre egyaránt (Törő, 2010).

\subsection{A hazai klímaváltozás jellemzői és hatásai}

A magyarországi éghajlat tendenciái és a valószínűsíthető változások egyaránt a hőmérséklet- és csapadékviszonyok várható kedvezőtlen változására hívják fel a figyelmet (Láng et al., 2007). Legmarkánsabb változás a hőmérséklet tendenciájában látható. Az országos átlag is a globális változásokat tükrözi, de annál valamivel nagyobb melegedési értékeket jelez (Szalai et al., 2005). Az elmúlt közel 100 évben évszakos felbontásban a telek és tavaszok az éves átlagoknak megfelelően alakultak, míg a nyarak jobban melegedtek, az őszök kevésbé. A havi középhőmérsékletek alapján az év 11 hónapjában mutattak ki melegedést, melyből 6 hónapban ez a folyamat szignifikáns, és 1 hónap, a december, ahol a hőmérséklet csökkent, de ez a változás nem szignifikáns. Magyarországon az 1975-1994 között az ország középső része jobban, míg a dél-nyugati és észak-keleti területek kevésbé melegedtek. Az utolsó két évtized átlaghőmérsékletét tekintve a keleti és észak-nyugati területek melegedtek jobban, mint az ország középső részén (Lakatos et al., 2011). Egyértelmü, hogy hazánk egész területén a hőmérséklet szigorúan növekvő tendenciát mutat, valamint évtizedes léptékben mindenütt folyamatos a melegedés. A világban sok helyen lassabb maximum és gyorsabb a minimum hőmérsékletek növekedése (IPCC Negyedik Értékelő Jelentés, 2007) nálunk nem tapasztalható. Nő a hőmérsékleti küszöbértékeket meghaladó napok száma. A hőség és forró napok jelentősen hatnak az élőlények szervezetére. Az átlagosnál hidegebb időszakok miatt nő a meleg időszakok intenzitása és gyakorisága, mely káros következménnyel járhat (Láng et al., 2007).

Magyarországon az éves csapadékmennyiség mértéke és eloszlása is megváltozott. E folyamat a magasabb hőmérséklet következménye. A hidrológiai ciklus intenzívebbé válhat, a csapadék egyre nagyobb része hullik le intenzív esőzés formájában. Sajnos romlik a csapadék 
természeti és gazdasági hasznosítása: kevesebb csapadék érkezik, a víz nagyobb része elfolyik, $\mathrm{s}$ kevés víz szivárog be a talajba, nő az árvízveszély. A csapadék évszakos eloszlása is megváltozott. Tavasszal az évszakos csapadékmennyiség csökkenése figyelhető meg, a XX. század eleji mennyiségnek csak a 75\%-a. A nyári csapadékmennyiség nem változott. Az őszi és téli csapadékmennyiség szintén csökken, de mérsékeltebb arányban, a csökkenés mértéke 1214\%-os. Télen az olvadó hó jelentős része beszivárog a talajba, melynek a vízháztartásban betöltött szerepe nagy. Ha ugyanis a vegetációs időszak elején a talaj felső rétege nem telítődik vízzel, akkor az komoly mezőgazdasági károkat eredményezhet. Területileg a csapadékcsökkenés az ország észak-nyugati régiójában a legjelentősebb. A probléma az, hogy a kevesebb csapadék intenzívebben érkezik, s ha hevesen és kis vízgyüjtő területekre zúdul, akkor hirtelen árhullámok alakulhatnak ki, melyek anyagi károkat és baleseteket eredményezhetnek. Az évi csapadék menetének változása is megfigyelhető, miszerint emelkedik a száraz időszakok hossza és gyakorisága, s vannak az átlagosnál csapadékosabb időszakok is (Lakatos et el., 2011).

A hőmérséklet és a csapadék együttesen is okozhatnak problémákat, például a hótakaró gyorsabban olvad el, amelynek hatására árvizek alakulnak ki, télen meleg időszakok után érkező hideghullám következtében a hótakaró nélküli talaj megfagy (Láng et al., 2007).

A globális klímaváltozás hazai összefüggései és változásai a különböző szektorokban is nyomon követhetők. A magyarországi klíma térbeli hatásai és az időjárás helyi jelenségei egyértelmüvé teszik, hogy hazánkban is foglalkozni kell a kárjelenségekkel és annak okaival, megelőzésével és elhárításának lehetőségeivel. Magyarországon komoly károkat okoznak a belvizek, árvizek, aszályok, özönvízszerü esők, jégesők, hőséghullámok, UV sugárzás emelkedése, korai és késői fagyok, hóakadályok, szélviharok, erdő és bozóttüzek, új kórokozók és kártevők megjelenése. A klímaváltozás hatása hazánkban minden szektorban érződik. A klímaváltozás által legfőképpen érintett területek (Láng et al., 2007):

1. vízügy: árvíz, belvíz, aszály, vízgazdálkodás

2. gazdaság, társadalom, infrastruktúra

3. humán- és állategészségügy, élelmiszerbiztonság, vízellátás

4. az ember által befolyásolt ökoszisztémák

5. természeti ökoszisztémák.

Az ember által befolyásolt ökoszisztémáknak - erdőgazdálkodás, növénytermesztés, állattenyésztés, kertgazdaság - is alkalmazkodniuk kell a klímaváltozás következményeihez. Az időjárási körülmények változásai - csapadék csökkenése, aszály, szélsőséges jelenségek érzékenyen érintik az erdőállományokat. A szélsőséges jelenségek hatására fokozódik a zöld felületek szerepe, mint például a pára megőrzése, a szén-dioxid elnyelése, a szén lekötése, az 
oxigénkibocsátás, az árnyékolás, a szelek mérsékelése szempontjából. A csapadék kulcsfontosságú a szántóföldi növénytermesztésnél, befogadása és megőrzése fontos kérdés. A vízhiány a talajok tápanyag-szolgáltatását is akadályozza. A bő csapadék pedig gombabetegségekkel károsít. A rovarkártevők tömeges megjelenése főleg a Dunántúlon fordult elö. A felmelegedés hatására szárazabb és melegebb viszonyok mellett a könnyebben alkalmazkodó fajok (parlagfü, gyapjaslepke, szúfélék) nagyobb mértékű elterjedése várható (Láng et al., 2007).

\subsection{A globális klímaváltozás hatása a természetes ökoszisztémákra}

Az Európai Unió „Alkalmazkodás a klímaváltozáshoz” című Zöld Könyve (EU Green Paper, 2007) és az IPCC (2007) jelentése szerint a globális felmelegedés várható következményei a vegetációs időszak meghosszabbodása és a virágzási időszak korábbra tolódása.

Számos állat- és növényfaj költözik magasabb tengerszint feletti területekre, illetve magasabb földrajzi szélességekre azért, mert a globális felmelegedés következtében élöhelye megváltozik, és a számára megfelelö körülményeket csak új helyeken találja meg. Ezzel együtt nő az invaziv - az adott területre betolakodó - fajok száma is, amelyek gyakran kiszorítják az őshonos fajokat. A felmelegedés a korábban nem erdősült területek erdősülését is lehetővé teheti, így a boreális erdők területe vélhetően növekedni fog a tundra rovására (EU Green Paper, 2007, IPCC, 2007).

Biológiai következményeként rengeteg élőlény élőhelyét veszélyezteti a globális felmelegedés, és becslések szerint több mint 1000 növény- és állatfaj kihal 2050-re (McLaughlin, 2002, Permesan, 2006). Az óceánok savasodása és felmelegedése várható. Az antropogén eredetü szén-dioxid-emisszió harmadát - naponta 25 millió tonnát - a tengerek nyelik el. Mivel a magasabb hőmérsékletü vízben a szén-dioxid rosszabbul oldódik, mint a hideg vízben, ezért az utóbbiak kémhatása jobban változik. A savas vízben a csigák, rákok, korallok, kagylók és tengeri sünök nem tudják kiválasztani a vízböl a vázuk felépítéséhez szükséges karbonátokat, ezért könnyen az óceán savasodásának áldozatává válhatnak (Hönisch et al., 2012).

Az éghajlatváltozás biológiai hatásainak elemzése és becslése összetett feladat, mivel a klíma mellett számos helyi tényező is hatással van az élővilág szerkezetére, összetételére és változási folyamataira.

A Természetvédelmi Világszövetség (IUCN, 2012) által kiadott Vörös Listája (www.iucn.org) szerint a világon már több mint 16 ezer növény és állatfajt fenyeget a kipusztulás veszélye. A klímaváltozás várható hatása rövid időn belül drasztikusan csökkentheti 
a biodiverzitást is. Az ökológusok az ökológiai rendszerek változásokat jelző szerepét, azok veszélyeztetettségét és fontosságát hangsúlyozzák. Az erdők füves pusztákká, a füves puszták sivataggá válhatnak. A prognosztizált csapadékhiány legnagyobb mértékben a vizes élöhelyeket veszélyezteti, de a szárazság fokozódása a szárazabb élőhelyek, és azok fajkészletének átalakulását eredményezheti. A makroklimatikus viszonyok már most is határhelyzetet jelentenek föbb erdőalkotó fajok számára. A hazai megfigyelések szerint hazánkban a kocsánytalan tölgy állomány 70\%-a már kipusztult (Láng et al., 2007).

A PIK Intézet (Potsdam Institut für Klimatfolgen-Forschung, www.pik-potsdam.de) modellje szerint, a jelenlegi szén-dioxid szint háromszorosára emelkedése esetén mediterrán örökzöld cserjések tenyésznek majd Angliában, az Alpok fenyveseit lomberdők váltják fel, és fátlan puszták foglalják el a Kárpát-medencét, Németország és Lengyelország egy részét (Mátyás, 2004, Führer és Mátyás, 2005a, 2005b, 2006).

Magyarország nagy részére a zonális erdőtársulások jellemzők (bükkösök, gyertyánostölgyesek, cseres-kocsánytalan tölgyes). A prognózisok a vegetációs övek eltolódását vetítik előre (Mátyás és Czimber, 2004). A növény- és állatfajok a klimatikus viszonyok tartós változására migrációval reagálnak, ami az area eltolódásához vezet. Ez a migráció a jégkorszak utáni fajvándorlással analóg, ami szintén klímaváltozás hatására következett be (Mátyás, 2004).

\subsubsection{A globális klímaváltozás hatása a rovarokra}

A klímaváltozásra a növényeknél is gyorsabban reagál az állatvilág (Borhidi, 2004). Azok a fajok, amelyek nem képesek alkalmazkodni a gyors éghajlati változásokhoz, legrosszabb esetben ki is pusztulhatnak.

A rovarok széles szerepkört töltenek be a természetben (biodiverzitás, mezőgazdasági és erdészeti kártétel, beporzás, ragadozás, lebontás, egészségügyi kórokozás, stb.), de természetesen a rovarokat sem kerülik el a klímaváltozás következményei.

A repülő rovarok jó indikátorok, mert nagy egyed és fajszám, rövid generációs idő jellemző rájuk, így gyorsan képesek reagálni a változásokra és reakciójuk látványos, jól detektálható (Kozár et al., 2004).

A klímaváltozás hatásaival foglalkozó kutatásoknál kiemelt rovarrend a lepkék rendje. Ennek oka a rendkívüli fajgazdagság, változatos életmód és ökológiai igények, sokféle környezeti érzékenység, gyakran magas abundancia-szintek, jó határozhatóság, valamint gazdasági és természetvédelmi jelentőségük. A változásokra történő nagyon gyors reagálásuk alkalmassá teszi őket a gyors eredmények kimutatására.

A globális felmelegedésnek lepkékre gyakorolt lehetséges hatásainak és a várható változások előrejelzésével, világszerte sok kutató foglalkozik. Ezen irányú kutatások már az 
1990-es években intenzíven folytak a nappali lepkék (Dennis és Shreeve, 1991), a mezőgazdasági kártevő lepkék (Farrow, 1991, Porter et al., 1991, Harrington és Woiwod, 1995), és az erdészeti kártevő lepkék (Hedden, 1989, Peters, 1990, Williams és Liebhold, 1995, Csóka, 1995; Leskó és mtsi, 1998a, 1998b, 1999) esetében.

A klímaváltozásnak már ma is jól mérhető időbeli és térbeli hatásait láthatjuk a lepkék esetében, mint például a fajszámok -biodiverzitás- jelentős csökkenése, a fenológiai változások -korábbi kitavaszodású években korábban indul a rajzás, aszinkronitás a tápnövénnyel, növekvő generációszám-, az északi félgömbön az elterjedési határok változása -magasabb szélességekre húzódnak- (Roy \& Sparks, 2000, Bjørnstad et al., 2002, Logan et al., 2003, Gienapp et al., 2005, Hagen et al., 2007, Szentkirályi és Leskó, 2007, Forrest \& Miller-Rushing, 2010).

A klímaváltozás a lepkék természetes ellenségeit, parazitoidokat és predátorokat is befolyásolja. A felmelegedő klíma, az enyhébb csapadékosabb telek a lepkéknek a patogének általi fertőzését is várhatóan elő fogja segíteni (Harvell et al., 2002).

Több külföldi kutató is foglakozott azzal a kérdéssel, hogy a klímaváltozás következtében hogyan változik a Kárpát-medence biodiverzítása (Szanyi, 2011, Hluchy, 1990, Kremar and Merdic, 1991).

Čamprag (2011) a klimatikus tényezők változása során az amerikai kukoricabogár (Diabrotica virgifera LeConte) elszaporodását vizsgálta a Kárpát-medence területén.

A lepkéket Magyarországon körülbelül 3500 faj képviseli. A vizsgált lepkefajok többségénél északra tolódást állapítottak meg. A klímaváltozás a magyar lepkefauna 55-81\%-át nem érinti. A mai fauna veszteségét maximálisan 19-45\%-ra teszik, melyek többsége északias elterjedésű faj. Hazánkban új fajok megjelenésére maximum a jelenlegi fauna 19-36\% -ának mértékében számíthatunk. Az érkező fajok areája döntően délkeleti jellegü (Petrányi és mtsi., 2007).

A klímaváltozás a növényvédelem területén ismert fajoknál is érezteti hatását. A múlt században hazánk területén csapdák által nem fogott rovarok is megjelentek, valamint jelentős károkat okoztak, mint például a hársbodobács (Oxycarenus lavaterae), gyapottok-bagolylepke (Helicoverpa armigera Hübner, 1808) vagy éppen a vadgesztenyelevél-aknázómoly (Cameraria ohridella Deschka et Dimič, 1986). Ezen mediterrán és szubmediterrán rovarok areája északra tolódott, míg például a gabona-aknázólegyek (Agromyzidae) ellenkező irányú area eltolódását figyelhetjük meg (Vörös, 2002).

Kozár és munkatársai publikációja (Kozár et al., 2004) és az erdészeti fénycsapda adatok a rovarok terén is jelzik a meleg kedvelő déli fajok megjelenését és terjeszkedését, valamint a nedvességkedvelö lepkefajok visszaszorulását. 
Európai kutatók a lepkék és a madarak areájának változását vizsgálták (Devictor et al., 2012). Megállapították, hogy a hőmérséklet növekedésével párhuzamosan az életterek észak felé tolódtak, míg a lepkék esetében átlagosan 135 kilométert, a madarak esetében pedig 212 kilométert. Az adatokat 1,5 millió megfigyelési óra alatt, több mint 11 ezer helyszínről gyüjtötték. A megfigyelt időszak alatt az éjszakai lepkék elterjedési területe 239 kilométerrel, míg a nappali lepkéké csupán 114 kilométerrel tolódott északra (Devictor et al., 2012). A meglepő a lepkék és madarak közti eltérés. Feltételezhetjük, hogy a lepkék érzékenyebbek a madaraknál, ezért jobban képesek követni a hőmérsékletváltozásokat. Ezek a kutatások az első bizonyítékok arra, hogy a klímaváltozás hatására egy egész kontinensen eltolódhatnak az elterjedési területek, ami a különböző állatcsoportok elszakadásához vezethet. "Sok madárfaj például egyes lepkefajok hernyóival táplálkozik, ezért számukra a klímaváltozás sok szenvedéssel járhat" - fejtette ki Josef Settele (2008). Az egyes országokban mért adatok között eltéréseket tapasztaltak (Devictor et al., 2012).

Coops és munkatársai (2005) az extrém események gyakoriságának és súlyosságának következményeit vizsgálta. Egy általa megalkotott térbeli modellező technika segítségével mutatta be, hogy a klímaváltozás hatására hogyan alakul a rovarpopulációk földrajzi elhelyezkedése. Éves és dekádos felbontásban is térképek segítségével ábrázolta az egyes fajok előfordulási zónáinak eltolódását. Megítélése szerint a kártevők megjelenésének ideje lényegesen megváltozhat, sőt maga az időpont is igen változékonnyá válhat, és ezzel az előrejelzés sokkal nehezebb feladat lesz mint napjainkban.

Porter és munkatársai (1991) tanulmányozták, hogy a XXI. század végére előre jelzett $3{ }^{\circ} \mathrm{C}-$ os átlaghőmérséklet-emelkedés milyen változásokhoz vezethet a földrajzi elterjedésben, a gyakoribbá váló áttelelésben a nemzedékszám növekedésében és a fejlődési szakaszok megrövidülésében.

Ellis és munkatársai (1997) az area jelenlegi elmozdulásairól tudósítanak a molylepkék terjedésében és biológiájuk módosulásában a klímaingadozás függvényében.

Farrow (1991) szerint a hőmérséklet emelkedésének hatására Ausztráliában a trópusi mezőgazdasági kártevők elterjedési területe megváltozik, egyre nő.

Több szitakötő és egyéb rovar észak-európai adatai igazolják a fajok elterjedési területének északabbra, illetve a tengerszint feletti egyre magasabb térszintekre történő tolódását, amelyek a klímaváltozás hatásainak tudható be (Hickling et al., 2005; Letho, 2003, Permesan, 1996, Permesan et al., 1999, Permesan and Yone, 2003, Walther et al., 2002).

Az éghajlat hatással van a fajok fitneszére, elterjedésére és tömegességére, a populációk dinamikájára, az ökoszisztémák szerkezetére és müködésére. A fajok elterjedése szoros kapcsolatban áll valamennyi éghajlati paraméter szélső értékeivel, ilyenek például a hőmérséklet, 
hótakaró, bozóttüzek éghajlat által meghatározott gyakorisága. Az éghajlati viszonyok gyors megváltozásával az egyes fajok és a belölük formálódó közösségek földrajzi elterjedését szabályozó egyensúly általános megbomlása várható. A fajok csak korlátozott mértékben tudnak vándorlással reagálni így a fajok elterjedésének változásai a kihalási és az inváziós folyamatok felgyorsulásával járnak együtt (Czúcz és mtsi., 2007).

A bekövetkező hőmérsékletváltozás az első és minden további nemzedék peterakási időpontját egyes fajok esetén eltolhatja úgy, hogy az egész életciklusukat felborítja. Ez egyes fajok kihalásához is vezethet. Az agráriumot abban az esetben hátrányosan érintheti, ha a biológiai védekezésben résztvevő fajok, azaz a kártevők természetes ellenségei tünnek el egyes területekről (Powell és Logan, 2005).

Leskó és munkatársai (1994, 1995, 1997, 1998, 1999) a fontosabb erdei kártevő lepkefajok hosszú tavú fénycsapdás fogásainak elemzése alapján rámutattak arra, hogy számos faj populációdinamikáját lokális és regionális léptékekben is a klimatikus hatások jelentősen befolyásolják.

Több klimatikus tényező hat a herbivor rovarok túlélési esélyeire és szaporodási sikerére is. Ismert kutatások pozitív összefüggést írnak le az aszály által növényeknél okozott stresszállapot és a rajtuk fejlődő rovarok populációdinamikája között (Waring és Price, 1990, Mattson and Haack, 1987).

Éghajlatunk egyre szárazabbá válását jelzik a házakat és kerteket elárasztó hangyapopulációk (Formicidae) tömege (Vörös, 2002). A vándorló állatfajok egy része hazánkban új típusú kártevőként jelenik meg, mivel jelentős gazdasági problémákat okoz, hiszen a megjelenő új állatpopulációk új tápnövényekre szoknak rá (Borhidi, 2004). Ezek fogadására mező- és erdőgazdasági növényvédelmünknek fel kell készülnie. E jelenség bizonyítékául szolgálhat az amerikai fehér medvelepke Hyphantria cunea (Drury, 1773) 2005. évi szokatlan méretü gradációja, vagy a sorfáinkat károsító aknázó molyok (például a vadgesztenyelevél-aknázómoly (Cameraria ohridella Deschka et Dimič, 1986) szintén erre a folyamatra utalnak. Ezeknek a változásoknak előrejelzésére készen állunk, hiszen az országos fénycsapda-hálózat több mint fél évszázada követi nyomon és jelzi előre a rovarpopulációk szaporodás-dinamikáját (Borhidi, 2004).

A több évtizedes szokatlan aszályos időjárás az erdei rovarok populációs fluktuációit jelentősen befolyásolta. Több erdei rovarfaj is jelentős kárt okozott, mit például az amerikai fehér medvelepke Lymantria dispar (Linnaeus, 1758), az aranyfarú szövő Euproctis chrysorrhoea (Linnaeus, 1758), levélsodró molyok (Tortricidae) a tölgy kéregpajzstetü Kermes quercus (Linnaeus, 1758), a fenyőrontó darázs Neodiprion sertifera (Geoffroy, 1785), a makkormányosok (Curculio ssp.), szúk (Scolytidae). Ezen fajok többségénél bebizonyosodott, 
hogy a kárterületi expanzió nagy mértékben a szélsőséges időjárás következménye. A hosszú aszályos időjárás következtében számos olyan melegkedvelő rovarfaj is jelentős károkat okozott, amelyeknek eddig nem ismertünk károkat okozó tömeges elszaporodását (Csóka, 1994, 1995, 1996).

A kis téli araszoló Operophtera brumata (Linnaeus, 1758) hosszú távú fénycsapdás idősorai során a maximális fogások rendszerint megelőzik egy évvel a gradációkat, $s$ megállapították azt is, hogy a gradációk kitörését a száraz, aszályos klímájú évek elősegítik (Leskó és mtsi, 1999).

Leskó és munkatársai (1999) vizsgálatukat több téli és tavaszi araszolófajra is kiterjesztették, ahol egyértelműen kimutatták, hogy a fénycsapda fogási csúcsai, illetve a kártételi csúcsok döntő többsége szignifikánsan egybeesett az aszályos évekkel, vagy közvetlenül a következő évben voltak különösen az O. brumata és az E. defoliaria esetében.

Az aszályos évek halmozódása fokozza az erdőkben a rovarkártételeket és a fapusztulást (Csóka, 2006). A gyapjaslepke (L. dispar) Európa számos országában, így hazánkban is az egyik legjelentősebb erdészeti kártevő. Legutóbbi tömegszaporodása (2003-2006) minden eddiginél nagyobb területen okozott károkat. A gradáció kialakulásában nagy szerepe volt a 2005-ös gradációs csúcsot megelőző erősen aszályos éveknek (Csóka és Hirka, 2009).

Az eddigi eredmények azt mutatják, hogy az erdészeti (lombfogyasztó) kártevők populációdinamikájára az aszályos években, gyakran gradáció (tömegszaporodás) kialakulása a jellemző, ami a vízhiány-stresszes állapotban lévő tápnövényben a nőstény lepkék termékenységét elősegítő metabolikus vegyületek (szénhidrátok, fehérje-hidrolizátumok) koncentrációjának megnövekedésével magyarázható (Martinat, 1987).

Az IPCC (2007) előrejelzése szerint az aszályos időszakok gyakoribbá válnak a jövőben, ennek következtében az előrejelzések az erdei kártevő lepkék elszaporodását, gyakoribb és súlyosabb mértékű tarrágását, valamint térbelileg északabbra tolódását prognosztizálják ÉszakAmerikában (Williams és Liebhold, 1995, Volney és Fleming, 2000, Logan et al., 2003). Egyes lepkéknél az aszályos időjárás lecsökkentette a szaporodási sikert (Pollard et al., 1997).

Az erdei rovarok és a patogének a legnagyobb problémát okozzák Észak-Amerika erdeibe. Kárterületük majdnem ötvenszer nagyobb, mint a tűzkárok területe. Azok a tulajdonságok, amelyek alapján egy növényevő rovart kártevőnek minősítenek a klímaváltozás, különösen a globális felmelegedés miatt megváltozhatnak. Sok kártevő kölcsönös viszonyban fejlődött más erdei fajokkal és a környezetükkel. Ez a viszony vagy káros volt vagy nem, de a kapcsolatok hosszú távú hatásai katasztrofálisak lehetnek. Eredményeik azt jelzik, hogy minden szempontból a rovarok gradációs viselkedését fokozza a klíma melegedése (Logan et al., 2003). 
Klok és Crown (2001) a növekvő hőmérséklet és az egyre gyakoribb intenzív csapadék következményeit vizsgálta a rovarok fenológiája tekintetében.

Ferenczy és munkatársai (2010) lepkék és növények adatsoraik alapján a fenológiai jelenségek, valamint a meteorológiai indikátorok kapcsolatainak összefüggéseit elemezték.

A lepkék fenológiai változásai közül az imágók korábbi tavaszi rajzása a legszembetűnőbb, ami a melegebb tavaszok következménye (Pollard és Yates, 1993). Roy és Sparks (2000) a brit országos lepke monitoring rendszerből (Butterfly Monitoring Scheme, BMS) származó adatok elemzésével vizsgálták a hőmérséklet és három fenológiai paraméter (rajzáskezdet, rajzáscsúcs, rajzáshossz) közötti kapcsolatot. A mintegy 20 éves adatsorok (19761998) elemzése során a legtöbb nagy-britanniai lepke rajzáskezdete korábbra tolódott és ez szoros kapcsolatban állt a korábbi rajzáscsúccsal valamint a többnemzedékes fajok esetében a hosszabb rajzásidőszakkal is. Vizsgálatuk alapján azt a következtetést vonták le, hogy zavaró tényezők hiánya következtében (mint például a más fajokkal való kapcsolat, vagy a területhasználatban bekövetkező változások) a klíma $1{ }^{\circ} \mathrm{C}$-os melegedése esetén az első megjelenés és a rajzáscsúcs a legtöbb lepke esetében 2-10 nappal tolódik majd korábbra. Ellis és munkatársai (1997) Hollandiában 104 Microlepidoptera faj adatait elemezve kimutatták, hogy átlagosan 11,6 nappal korábbra tolódott a rajzáscsúcs az 1975-1994 közötti periódus alatt. Fenológiai változásokat vizsgálva a hosszú távú elemzések kimutatták, hogy az éghajlat $3{ }^{\circ} \mathrm{C}-\mathrm{kal}$ történő felmelegedése a lepkék megjelenését két-három héttel előbbre tolják (Sparks and Carey, 1995, Sparks and Yates, 1997).

Az éghajlatváltozás valószínüleg másképpen fogja befolyásolni a fenológiai táplálékszinteket és ezáltal megzavarják a fenológiai szinkronitást a ragadozó és a zsákmánya között. Ahhoz hogy megjósolhassuk, hogy a különböző klímaszcenáriók esetén milyen zavarok merülhetnek fel a szinkronitásban, szükségünk van a különböző fajok fenológiáját jól leíró modellekre. Sok fenológiai modell azon alapul, hogy visszamenőleg összeveti a megfigyelt fenológiai eseményt egy adott periódusban mért hömérsékletekkel. Probléma különösen, hogyha a jövőbeli eseményeket próbáljuk megjósolni, mert olyan paradox helyzet alakul ki, hogy a fenológiai esemény időben megelőzi azt az időszakot, amikor a hőmérsékletet mérik. Az ilyen modellek képtelenek megjósolni a fenológián belüli populáció változásokat. Gineapp és munkatársai (2005) tanulmányukban bemutatnak egy ,arányosított-kockázati modellt” a fenológia leírására és ezt egy a madarak szaporodásából vett példával illusztrálják. Ez a fajta modell általánosan alkalmazható a fenológia leírására, ami alapvető fontosságú, amikor a klímaváltozás ökológiai hatását vizsgáljuk (Gienapp et al., 2005).

A fenológia hatással van az ökológia és az evolúció szinte valamennyi aspektusára. Gyakorlatilag minden biológiai jelenség éves ciklussal bír és számos abiotikus tényező hat rá. Az 
utóbbi évtizedben ugrásszerűen megnőtt az érdeklődés és egyre több tanulmány íródott a klímaváltozásra adott fenológiai válaszokkal kapcsolatban. Sok kutatás foglalkozik a fenológia genetikai vezérlésével, modellező módszerekkel, a fenológiai változás ökoszisztéma szintű és evolúciós következményeivel. Forest és Miller-Rushing (2010) vizsgálta a fenológia és az élettartam viszonyát, a fenológia és a szervezet- és populáció szintü perspektívák közti különbségeket, valamint a fenológiának az evolúciós folyamatokra, az életközösségekre és az ökoszisztémákra gyakorolt hatását. További céljaik között a fenológia ökológiai és fiziológiai vonatkozásainak összekapcsolása áll.

A lepkék zöme a tápnövényük fenológiai változásaihoz alkalmazkodik, és velük szinkronban fejlődik. A fotóperiódus és a hőmérséklet is befolyásolja azokat a fiziológiai mechanizmusokat, amelyek a tápnövények és a lepkehernyók fenológiáját meghatározzák. Ha a felmelegedés különböző fejlődési ütemet eredményez a tápnövény és herbivórja számára, akkor az adaptív szinkronizáció időbeli elcsúszást eredményezhet a lepkehernyók megjelenése és a táplálékuk elérhetősége között. Erre a trofikus-fenológiai kapcsolatra jó példa a kis téli araszoló (O. brumata), amely lárváinak fiatal rügyekre, hajtásokra van szüksége, hogy elkerülje a kedvezőtlen hatású tanninok későbben növekvő koncentrációját (Buse és Good, 1996, Buse et al., 1998, 1999). Az elmúlt 25 éves intervallumban a melegedő tavaszok és az elmaradó fagyos időszakok következtében az O. brumata és tápnövénye a kocsányos tölgy (Quecus robur) közötti szinkronizáció nagyon meggyengült: a tojásokból egyre korábban kelnek ki a hernyók a rügyfakadáshoz képest, a kis lárvák pedig 1-2 napnál tovább nem nagyon bírják az éhezést. A predikció szerint akár 3 hét elcsúszás is lehetséges a klímaváltozás előre haladtával (Visser és Holleman, 2001). A növekvő hőmérsékletek és emelkedő $\mathrm{CO}_{2}$ koncentráció a tölgylevelek nitrogéntartalmát lecsökkenti, a tanninokét, valamint a levél keménységét növeli, mindez hátrányosan érinti a téli araszoló lárvák levélfogyasztását (Dury et al., 1998).

Ayers és Lombardero (2000) a táplálékhálózat szemszögéböl végzett elemzéseket. Megállapításaik szerint a klímaváltozás közvetlenül hat a növények növekedésére, fiziológiai hatással van a növények kártevő elleni védelmére és közvetett hatással van a növényekre a kártevő populációkban végbemenő ragadozó-zsákmány, versengő és kölcsönösen segítő kapcsolatok megváltozásán keresztül.

A szaporodás időzítésének fontos fitnesz következményei vannak, ezek csak akkor érthetők, ha az utódok mennyiségét a táplálék fenológiája határozza meg. A rovarevő madarak, mint például a széncinege számára fố szelekciós nyomást az jelenti, hogy szinkronizálják az utódaik igényeit a hernyók abudanciájával (Visser et al., 2006). A melegebb tavaszok miatt a hernyók korábban kelnek ki, ami a cinegéket is hátrányosan érinti, mivel a költési időszakban a cinegék fiókáikat a téli araszoló lárvákkal etetik. A felmelegedés a vizsgálatok szerint nem jár a 
költésnek a zsákmányhoz történő korábbi időzítésével (Buse et al., 1999). Ezzel ellentétes eredményre jutottak Visser és munkatársai (2006). 20 éves perióduson keresztül mérték a hernyók biomassza mennyiségét és kimutatták, hogy az éves csúcsértékük korrelál a március 8 . és május 17. közti hőmérsékletekkel. A cinegék költési ideje szintén korrelál a hőmérséklettel, de egy korábbi időszakban március 16. - április 20. között. A hernyók számának csúcsértéke is korrelál a hőmérséklettel. A korábbi időszakban a madarak fenológiáját és a hernyók biomasszáját összevetve nem tapasztaltak különbséget. A március 16. - április 20. között a hernyók mennyiségének maximuma és a hőmérsékletek közti kapcsolat a klímaváltozás következtében változik, amíg a madarak költési ideje nem változik. Ennek következménye, hogy az elmúlt meleg évtizedekben zavar támadt az fiókák tápanyagszükségletei és a hernyók biomassza szinkronítása között. Ennek súlyos következményei lehetnek, mivel mindez befolyásolja a fiókák számát és testsúlyát is. A 2005-2100-as időszakra tekintve az előrejelzések szerint a madarak korábban kezdenek el költeni, s ez ugyanannyi idővel fog korábban bekövetkezni, mint ahogy a hernyók mennyisége eléri a maximumát. Emiatt nem fog csökkenni a jelenlegi körülbelüli 10 napos időeltérés (Visser et al., 2006).

A rovarok gradációja jelentős hatással van a tápanyagforrásra, a szén-dioxid megkötésére és a biológiai sokféléségre (Ayres and Lombardero, 2000).

A klímával kapcsolatos változások nem csak a tápnövényekre és az azokat fogyasztó fitofág rovarokra, hanem a táplálkozási hálózatok valamennyi komponensére, így a kártevők természetes ellenségeihez tartozó ragadozó vagy parazitoid rovarokra is hatással lehetnek. Ilyen ragadozókkal kapcsolatos elemzéseket a futóbogarakkal és a fátyolkák hosszú távú fénycsapdás adatsorain végeztek (Kádár és Szentkirályi, 1997, Szentkirályi és mtsi., 1995, 1998).

A klímaváltozás hatásainak modellezése során szinte minden kutató kiemeli a rovarok érzékenységét a hőmérsékletváltozásra. A klímaváltozás a légköri szén-dioxid mennyiségének változásának is köszönhető. Grodzinski és munkatársai (1999) a légköri szén-dioxid hatását vizsgálják a rovarokra nézve.

Negyedszázaddal ezelőtt felmerült a kérdés, hogy lehetséges-e egy általános hipotézis segítségével magyarázatot adni az erdei lepkék gradációjára. Azóta jelentős előrehaladás történt és sikerült megmagyarázni több mechanizmust, amelyek kapcsolatban állnak az erdei lepkefajok populációdinamikájával. A rajzás-dinamikát befolyásoló tényezők között gyakori a késleltetett sürüséggel összefüggő parazitizmus és a gradáció idején jelentkező csökkent termékenység, bár ez utóbbira még nincs magyarázat. A melegedő éghajlat hatásaként módosulhat a fajok megoszlása és a rajzásdinamikája, de a magyarázó mechanizmusokat még nem tárták fel, és a bekövetkező változások sem nyilvánvalóak mindenhol (Myers and Cory, 2013). 


\subsection{Matematikai modellezés}

A tudományos megismerés folyamatában fontos szerepet játszanak a modellek. A matematikai modellek valamilyen vizsgált rendszerben lejátszódó jelenség, folyamat vagy tevékenység a vizsgálat szempontjából lényeges tulajdonságai közötti összefüggések matematikai megfogalmazása. A matematikai modellek robbanásszerű elterjedését az informatika fejlődése tette lehetővé. A főbb modelltípusok különböző szempontok szerinti felosztásai az alábbiak:

- Taktikai, illetve stratégiai modell

- Szimulációs, illetve leíró modell

- Diszkrét, illetve folytonos modell

- Determinisztikus, illetve sztochasztikus modell

Léteznek nagyrendszer-modellek, mint a háromdimenziós térben zajló mozgásokat leíró általános cirkulációs modellek, például a Globális Légköri Cirkulációs Modellek (GCM-ek), vagy az ökoszisztéma modellek, amelyek a környezeti információs rendszerek fontos részét képezik, ezek a modellek a fentiek közül több különböző típusú részmodellt tartalmazhatnak (Szücs, 1972, 1990).

Számos kutató modellezi a bioszféra lehetséges változásait a klimaváltozás hatására. A globális vegetáció modellek a klimatikus viszonyokat vetik össze a vegetációval (Foley et al., 1996). A klímaváltozás jövőre vonatkozó becsléséhez szén körforgás klímamodelleket is használnak (Sarmiento et al., 1998, Joos et al., 1999, Dufresne et al., 2002, Friedlingstein et al., 2003, Zeng et al., 2004).

Napjainkban sok területen merül fel az igény a szintézisre, a különböző tudományágak együttmüködésére. 1970-es évektől a világ különböző helyein szinte egyszerre virágzott fel a mezőgazdaságban is a szintézist teremtő modellezési munka, a szakadékok áthidalása, a részterületek speciális ismereteinek egyetlen rendszerben, egyetlen modellben való összefoglalása. A modellező tudós így ma már nem csupán „mindenről tud egy keveset, hanem „valamiről eleget” is. Az ökológiai szemlélet jelenleg is egyre erősödik (Huzsvai, 2011).

A körülöttünk lévő jelenségeket a maguk komplexitásában, okaik és lehetséges következményeik figyelembevételével kell vizsgálni, és nem kiragadni belölük egyet-egyet (Huzsvai, 2008). Ma már a klímaváltozás aktuális problémát jelent a növény- és erdővédelem számára is, ezért fontos a klímaváltozás következményeinek, valamint az üvegházhatásnak a rovarokra gyakorolt hatását modellezni (Karafyllidis, 1988; Velichko et al., 1993). 


\subsubsection{Szimulációs modellek}

Az ökológiai rendszerek elméleti célból végzett biológiai-matematikai leírása, modellezése mellett megkülönböztetjük a gyakorlati alkalmazás céljából végzett ún. szimulációt (Ladányi, 2006). A szimulációs modellek közvetlen célja ma az, hogy az igen bonyolult rendszerek folyamatait, ide értve az emberi tevékenységet is, matematikai eszközökkel írják le, és számítógép segítségével szimulálják. A végső cél az, hogy ezen modellek felhasználásával olyan kérdésekre kapjunk „,ha ..., akkor ...” (,,what if’) típusú választ, amelyeket egyébként csak nagyon költséges, időigényes vagy kivitelezhetetlen kísérletek, illetve megfigyelések segítségével valósíthatnánk meg. Mindemellett a szimulációs modell az a modelltípus, amely a vizsgált jelenséghez hasonló viselkedés megmutatására képes, vagyis a modell viselkedési elemei és a valóságos rendszer viselkedési elemei között egyértelmű kapcsolat teremthető. (Szücs, 1972, 1990).

Az informatika fejlődésével vált lehetővé széles körben a kutatók számára az addig felhalmozott természettudományos ismeretek számítógépes algoritmusokkal való megfogalmazása, és az első szimulációs modellek elkészítése. Ettől kezdve egyre több szimulációs modellt alkalmaztak a különböző oktatási és kutatási projektekben, és a modellezési technika a természettudományok különböző területén (ökológia, genetika, fiziológia) felismert törvényszerüségekkel egy időben gyorsan fejlödött (Huzsvai, 2008). A terepi mérőmüszerek színvonala emelkedett, s emellett adataiknak megbízhatósága is rengeteget javult.

A szimulációs modell akkor bizonyul jobbnak, ha minél több, de a szükséges mennyiséget nem meghaladó paraméterre terjed ki, illetve ha a kellően specifikus modellek közül minél egyszerübb. A szimulációs modellezés első képviselői de Wit, Keulen, Goudriaan, Passioura, (de Wit és Keulen, 1972, de Wit és Goudriaan, 1974, Goudriaan, 1977, Passioura, 1973), akik a modellezéstudományt új irányba terelték (Ladányi, 2006).

\section{A szimulációs modellek alkalmazása az élettudományokban}

Az első jelentős biológiai szimulációs modellek közé tartozik a Shelford-féle táplálékhálózati modell (Shelford, 1913), illetve a Jones-féle rovarpopuláció-modell (Jones et al., 1975). Az elmúlt harminc évben a biológiai szimulációs modellek fejlödése felgyorsult, mialatt számos táplálékhálózatokkal kapcsolatos elmélet született (Ladányi, 2006).

Különböző kutatási irányzatok alakultak ki: energetika, populációdinamikai, stabilitáselméleti, gráfelméleti, rendszerelméleti, információelméleti (Ulanowicz, 1983; Ulanowicz and Wolf, 1991). 
Aukema és munkatársai (2006) az erdei közösségekben fellelhető szimbiotikus kapcsolatokat írják le.

A klímaváltozás különösen érzékenyen érinti a vízi ökoszisztémákat. Hufnagel és munkatársai (2012) a természetközeli populációk és ökoszisztémák, vízi rendszerek esetében végeztek modellezési esettanulmányokat. Ladányi és Hufnagel (2006) a platánfa-csipkéspoloska abudancia-csúcsait modellezték a klimaszcenáriók tükrében.

Sipkay és munkatársai (2010) a dunai fitoplankton adatbázisára illesztett szimulációs modell alapján elemezték a lineáris hőmérsékletemelkedések hatását.

Számos kutató különböző rovarcsoportokat vizsgált eltérő célokkal: Tchuenche (2005), valamint Rasgon és Scott (2004) is kormegoszlás szerinti modellel dolgozik. Castañera és munkatársai (2003) állapotstrukturált modellje betegségközvetítő rovarokra készült. Egyedsürüségtől függő modelleket készít Matter (2003), illetve White és Wilson (1999). Kindlmann és Dixon (1996) a tavaszi és őszi rajzás közti kapcsolatot elemzi. A térbeli- és időbeli terjedést (az inváziót és az elszaporodás jelenségét) modellezi Sawyer és Haynes (1985). Speciálisan szárnyas rovarokra dolgoz ki ilyen jellegü modellt Raffy és Tran (2005). A térbeli természetes határok rovarpopulációra gyakorolt hatásaival foglakozik Marsula és Wissel (1994). Shaffer és Gold (1985) olyan fenológiai modellt alkotott, amely tartalmazza a rovarirtóra való válaszadást is. Rubtsov (1983) egy levélszívogató rovarpopulációt modellezett. Rausher (1985) valamint Paoletti és munkatársainak (1992) modelljei is a biodiverzitás problémájával foglalkoznak. A rovarok társadalmi felépítését modellezik Pie és munkatársai (2004), valamint Brandts és munkatársai (2001).

A rovarmodellezők is alátámasztják és hangsúlyozzák a rovarpopulációk nagyfokú érzékenységét a hőmérséklet változására. A levegő $\mathrm{CO}_{2}$-tartalmának rovarokra gyakorolt hatását mutatja be Grodzinski és munkatársai cikke (1999).

További populációdinamikai szimulációs modelleket használtak Crozier és munkatársai (2006) a nyári és a téli időjárási viszonyok busalepkékre (Hesperiidae) gyakorolt hatásának vizsgálata során. Mutshinda és munkatársai (2011) az egyes fajok közti interakciót is figyelembe véve téli hőmérséklet és csapadék változókkal magyarázza az éjszakai nagy lepkék egyedszámának alakulását.

Radchuk és munkatársai (2013) vizsgálatukban külön modellel írják le a különbözö fenofázisok egyedszámát úgy, hogy figyelembe veszik az időjárás és az egyes fenofázisok mortalitási tényezőit. Cormont és munkatársai (2012) azt vizsgálják, hogy a hőmérsékleti és csapadék adatokat valamint a regionális klímamodell kimeneteleit felhasználva, a lepkék milyen fenológiai eltolódással kompenzálják a klimatikus viszonyok változásait. 
Hernández-Zul és munkatársai (2013) a hőmérséklet, a csapadék és a talaj fizikai tulajdonságai alapján becsülik egy amerikai kétnemzedékes kártevő sáska (Orthoptera: Acrididae) egyedszámát, majd meghatározták a rovar számára optimális, illetve az attól eltérő időjárási körülmények esetén fennálló kockázatot.

\section{A populációdinamikai szimulációs modellek speciális alkalmazási területei}

A populációdinamikai modellezések módszereit, eredményeit széles spektrumú területen lehet hasznosítani (Ladányi, 2006):

- Az erdőgazdálkodás témakörében kutatnak Bazykin és munkatársai (1997), valamint Wagner és munkatársai (1984).

- Az élelmiszeripari terméstárolási problémát próbálják megoldani a tárolókban előforduló kártevő-populációk modellezésével Flinn és munkatársai (2004), Thorpe (1997), Thorpe és munkatársai (1982), valamint Kawamoto és munkatársai (1992).

- Rovarpopulációk okozta pollenterjedéssel foglalkozik Di Pasquale és Jacobi (1998).

- Biológiai növényvédelem szolgálatába állítják Bianchi és van der Werf (2004), Heinz és Nelson (1996), Godfray és Briggs (1995), Mills és Getz (1996), továbbá Potting és munkatársai (2005).

- A klímaváltozás hatásainak vizsgálatára alkalmazzák Harrison és Butterfield, (1998), Harrison és munkatársai (1995), Cannell és munkatársai (1989), Cooter (1990), Kenny és munkatársai (1993), Semenov és Porter (1995), valamint Semenov és munkatársai (1993).

A rovarpopulációk modellezésénél a kalibrálást rendszerint fénycsapdaadatokkal végezzük. Igen érdekes problémával foglakoznak Potting és munkatársai (2005), jelesül, hogy a populációk aktuális paramétereitől, továbbá az időjárástól hogyan függenek a fénycsapdák adatai.

Napjainkban igen fontos és aktuális kérdés a környezetvédelem mellett a klímaváltozás hatásának vizsgálata, modellezése, valamint az üvegházhatásnak a rovarokra gyakorolt hatásának modellezése (Karafyllidis, 1988, Velichko et al., 1993). A rovarpopulációk dinamikájának előrejelzése céljából modelleznek Gross és munkatársai (2005).

\subsubsection{Klímamodellek}

Ha az éghajlatimodell fogalmát defíniáljuk, akkor az éghajlati változás, illetve változékonyság számszerü vizsgálatára kialakított, modern informatikai rendszereket használó kutatási eszköz. Az 1950-es évektől használunk éghajlattal kapcsolatos számítógépes 
modellkísérleteket. Neumann János vetette fel, hogy a rövidtávú számítógépes előrejelzési modellböl hosszú idejű futtatás esetén szimulálni lehetne az általános légkörzés kvázistacionárius viszonyokat. A világon elsőször 1956-ban publikáltak általános cirkulációs modellkísérlet eredményeket (Phillips, 1956). Az éghajlat-modellezés alapjait tette le J. Adem, aki E. Lorenz-cel együttmüködve a légköri folyamatok hosszútávú dinamikai elörejelzésén dolgozott (Adem, 1965).

A teljes éghajlati rendszert szimuláló modelleket globális klímamodelleknek nevezzük. A föbb modellek, melyeket az egész Földre érvényes éghajlati rendszer dinamikus modellezéséhez alkalmazunk:

- Hidrodinamikai modellek: A légkörben és az óceánokban bekövetkező változásokat együttesen figyelembe vevő modellek. A külső és a belső erők hatására létrejövő áramlásokat elemzik, amelyek kulcsszerepet játszanak az éghajlat kialakításában.

- Numerikus modellek: Ezekben a modellekben a számításokat numerikus és közelítő módszerekkel végzik. A numerikus modellezés az alapvető fizikai törvényszerüségeken alapul, melyek közül a legfontosabbak a tömeg-energia és az impulzusmomentum megmaradásának elve. Ezek a modellek szimulálják a légkör és az óceánok mozgását, becsléseket végeznek a légnyomás, hőmérséklet és a sürüség várható értékeire (McGuffie és Henderson-Sellers, 2001).

- Globális modellek: Ezek a modellek a Föld egész légkörére és az óceánok összességére vonatkoznak. A térben folytonos légkörfizikai állapotjelzők időbeli változását úgy kezelik a modellekben, hogy a mezőkre egy rácshálózatot illesztenek. A különféle matematikai számításokat ezután már csak a hálózat csomópontjaira, az úgynevezett rácspontokra végzik el. A globális modellek hátránya, hogy kicsi a térbeli felbontásuk, ezért a már két nagyságrenddel kisebb skálájú folyamatokat nem képesek vizsgálni.

- Regionális modellek: Tulajdonképpen ezek a modellek a globális modellek finomításai. Kidolgozásuk sokkal energiaigényesebb a globális modellekénél.

- Általános légkörzési modellek (GCM - General Circulation Model): Ezen modelleket régóta és számos területen használják a globális felmelegedés különböző hatásainak elemzésére (Kertész, 2001). A GCM legelső használataira a múlt század nyolcvanas éveinek közepe táján került sor (Warrick et al., 1986). Az általános légkörzési modellek az üvegházhatások modellezésére használt legelterjedtebb modellek, amelyek háromdimenziós térben írják le a légkör, az óceán és a földfelszín fizikai folyamatait. Tanulmányozzák a napsugárzás energiájának szféránkénti megoszlását, az energia hatását az éghajlati rendszer elemeire, számításokat végeznek a hőmérséklet, csapadék, 
légnyomás és egyéb éghajlati változók értékeire vonatkozóan. Horizontális felbontásuk átlagosan 100-300 km. A GCM-ek legkomplexebb modellek, de ugyanakkor a legnehezebben alkalmazhatóak.

Az általános éghajlati modellek közül a ARPEGE-Climate időjárás-előrejelző modell és az ebből kifejlesztett ALADIN-Climate modell, a német időjárás-előrejelző modellből kifejlesztett REMO regionális klímamodell szélesebb körben ismert. További fontos regionális modellek még a PRECIS, az ECMWF valamint a Special Report on Emissions Scenarios (SRES). Magyarországon az ALADIN-Climate, a PRECIS, a RegCM és a REMO regionális klímamodelleket alkalmazzuk (Szépszó és mtsi., 2013). Az elmúlt 10 évben, az antropogén hatásokról szerzett tapasztalatok alapján szükségessé vált az ún. SRES (Special Report on Emissions Scenarios; Nakicenovic et al., 2000) szcenáriók felülvizsgálata, s a fejlődési irányhoz és ütemhez jobban illeszkedő új forgatókönyvek kidolgozása. Az IPCC ötödik helyzetértékelö jelentésben már újabb globális modellfuttatások az ún. stabilizációs (Moss et al., 2010) szcenáriókat alkalmazzák, melyeket a 2100-ra feltételezett sugárzási kényszerrel jellemeznek (Szépszó és mtsi., 2013).

Elörejelző modellek: Az elörejelző modelleknek több kritériumnak is meg kell felelniük. Figyelembe kell venniük, hogy az üvegházgázok ember általi kibocsátása változhat a jövőben, például a korlátozó rendszabályok miatt. Ezért az éghajlati modellekben is figyelembe kell venni a különféle emissziós forgatókönyveket, majd ennek megfelelően módosítani az előrejelzéseket. A modelleket nemcsak az általános felmelegedésre kell alapozni, hanem figyelembe kell venni a különböző földrajzi régiókban az évszakonkénti változás jellegét is.

\section{Globális klímamodellezés}

Ma a globális klímamodellezéshez elsősorban a légkör-óceán általános cirkulációs modelleket (AOGCM) használják. A technika, illetve a számítástechnika fejlődésével az egyes modellek egyre komplexebbé válhattak, a szimulált időszak egyre nagyobb intervallumú, valamint a térbeli és időbeli felbontása egyre finomabbá vált (Trenberth, 1992). A világon a nagy éghajlatkutató központokban az egész Földre érvényesülő, nagy számításigényü klímamodelleket (1. táblázat) futtatnak. 
1. Táblázat $A$ főbb általános cirkulációs modellek

\begin{tabular}{|l|ll|}
\hline FEJLESZTÉS & \multicolumn{2}{|c|}{ MODELL } \\
\hline német & ECHAM & (Roeckner et al., 1995) \\
\hline angliai & UKMO-HadCM3 & (Gordon et al., 2000) \\
\hline japán & MIROC3.2 & (Collins et al., 2006) \\
\hline amerikai & CCSM & (IPCC, 2007) \\
\hline francia & CNRM-CM3, IPSL-CM4 & (IPCC, 2007) \\
\hline kanadai & CGCM3.1 & (IPCC, 2007) \\
\hline kínai & FGOALS-g1.0 & (IPCC, 2007) \\
\hline koreai & ECHO-G & (IPCC, 2007) \\
\hline amerikai & GISS-EH, GISS-ER, GISS-ER, GFDL-CM2.1, PCM & (IPCC, 2007) \\
\hline orosz & INM-CM3.0 & CSIRO-Mk3.0
\end{tabular}

$\underline{\text { Regionális klímamodellezés }}$

A globális klímamodellek a gyakorlatban nem igazán használhatók a klíma regionális szinten való szimulálására. A globális klímamodellek a Föld légkörének általános melegedését mutatják, de nagy valószínűséggel lesznek olyan területek, ahol csökkenni fog a hőmérséklet, s ez a jelenség a csapadékra még inkább igaz. Ezért is volt szükséges regionális léptékü, reális eredményeket nyújtó klímamodellekre.

Három intézet és egy iroda bevonásával kezdődőtt meg 2005-ben a regionális klímadinamikai kutatás. A közös munkában az Országos Meteorológiai Szolgálat (OMSZ), az Env-in-Cent Kft, a Pécsi Tudományegyetem (PTE) és az Eötvös Loránd Tudományegyetem (ELTE) Meteorológiai Tanszéke vett részt. A munka egyik legfontosabb része az eltérö regionális éghajlati modellek átdolgozása volt. Az átalakított regionális éghajlati modellek alapul szolgálnak a Kárpát-medencében várható éghajlatváltozás becslésére. Ma hazánkban négy regionális klímamodell az alapja a magyarországi klímadinamikai vizsgálatoknak, melyek közül az ALADIN-Climate és a hamburgi Max Planck Meteorológiai Intézet által kifejlesztett REMO modellket az Országos Meteorológiai Szolgálat, míg a Hadley Központ PRECIS regionális klímamodelljét és a RegCM-et az ELTE Meteorológiai Tanszék tette alkalmassá a régióban történő alkalmazhatósághoz (Torma, 2011).

A vizsgálatok elsődleges célja ismereteink bővítése a Közép- és Kelet-Európában várható helyi klímaváltozásról és annak különböző területekre gyakorolt hatásairól, mint például a levegő minőségére, a vízháztartásra, az erdészetre és a mezőgazdaságra. Ma hazánkban négy regionális klímamodell az alapja a magyarországi klímadinamikai vizsgálatoknak, melyek közül az ALADIN-Climate (Csima és Horányi, 2008) és REMO (Szépszó és Horányi, 2008, Szépszó et al., 2008) modelleket az OMSZ, míg a PRECIS (Bartholy et al., 2006a, 2006b, 2009a, 2009b, 
Pieczka et al., 2009) és a RegCM (Torma et al., 2008, 2011) modelleket az ELTE Meteorológiai Tanszéke adaptálta és alkalmazta.

\section{$\underline{\text { A RegCM klímamodell és alkalmazása }}$}

Az ELTE Meteorológiai Tanszékén a CECILIA (Central and Eastern Europe Climate Change Impact and Vulnerability Assessment, http://www.cecilia-eu.org) európai uniós projekt keretében került sor a RegCM regionális modell adaptálására a Kárpát-medence térségére. A Magyarországot lefedő integrálási tartomány 120×100 rácspontot tartalmaz (Torma et al., 2008). A RegCM regionális klímamodell kifejlesztése az Amerikában történt az 1980-as évek végén (Dickinson et al., 1989, Giorgi, 1989). A vizsgálatokhoz 10 km-es horizontális felbontással, 18 vertikális szintre a 3-as verziószámú RegCM (RegCM3.1) modellt alkalmazták. Az A1B globális emisszió szcenárióra készültek el a modell szimulációk, melynek feltételezése szerint a Föld teljes lakossága néhány évtizeden belül 9 milliárdra növekszik, és ezután a század végére fokozatosan 7 milliárdra csökken. Az A1B szcenárió a légköri széndioxid koncentrációjának kismértékü növekedését jósolja, mely 2100-ra meghaladhatja a 715 ppm-et (Nakicenovic és Swart, 2000). A RegCM modell futtatásához az ECHAM5 (Roeckner et al., 2003) globális éghajlati modell biztosította a kezdeti és határfeltételeket (Bartholy et al., 2010).

\subsection{A fajok ismertetése}

\section{A kis téliaraszoló (Operophtera brumata Linnaeus, 1758)}

$\mathrm{Az} O$. brumata egynemzedékes, egész Európában, Transz-Kaukázusban és KeletÁzsiában elterjedt közönséges faj, euro-szibériai faunaelem. Észak-Amerikába is behurcolták, ahol mára már szintén jelentős lombrágóként tartják nyilván. A síkságtól a magashegységig mindenütt megtalálható. Polifág, igen sok tápnövényét ismerjük (Szabóky és Csóka, 2008). Az ősszel és télen lerakott peték áttelelnek. Tavasszal időjárástól függően március elejétől-közepétől kelnek ki a még sötét testü és fekete fejü hernyók (2. táblázat). A hernyók kikelése rendszerint egybeesik a lombos fák fakadásával. A petéből kikelő hernyók eleinte a fakadó rügyeket károsítják, ilyenkor teljesen berágják magukat a rügyekbe, később a virágbimbókat és a virágokat rágják. Lombfakadás után a levélcsomókat lazán összeszövik, a rágás mindig összefont levelek között történik, a leveleket lyuggatják, vagy karéjosan rágják.

Egy hernyó tápanyagszükséglete $40-50 \mathrm{~cm}^{2}$ levélfelület. A hernyók föleg éjjel rágnak. Időjárástól függően 25-40 nap alatt fejlődnek ki (Tóth, 1999), ezalatt 5 fejlődési fokozaton haladnak végig. Május első felében kezdenek távozni a fákról, ahol május közepén már csak a parazitált hernyók találhatók. A kifejlett hernyó mérete 25-30 mm (Csóka, 1995), amelyek a 
fákról selyemszálon leereszkednek, vagy a törzsön lemásznak, és a talaj felszínén (47,2 \%), vagy a talaj legfelső 3-8 cm-es rétegében (52,8 \%) kemény falú gubót szőve bábozódnak be.

A bábok a korona védőlombja alatt koncentrálódnak, a bábozódás mélysége a talaj tulajdonságaitól és az aljnövényzettől függ, kötött talajon $2 \mathrm{~cm}$, homoktalajon $6 \mathrm{~cm}$ mélyen. A nyarat bábállapotban, diapauzában töltik, majd októbertől január elejéig rajzanak. A bábból való kikeléshez rendszerint egy nagyobb, áztató jellegű őszi eső szükséges. A bábokból az első fagyok után kelnek ki a lepkék. A lepkék kikeléséhez nagyobb csapadék és megfelelö hőmérséklet szükséges (fagymentes időszak). A lepke általában október végén jelenik meg. A hímek rendszeresen pár nappal korábban jelennek meg, mint az apró szárnycsökevényt viselő nőstények. Napközben az avaron vagy a fatörzsön ülve pihennek. A hímek az őszi napnyugtától (kb. 16 órától) kezdve repkednek a lomb nélküli fák között. A rajzás 6-8 hétig, akár hóesésben is folyamatosan tart, csak az egybefüggő vastag hótakaró és az erős fagyok jelentenek akadályt (Szőcs, 1976). Erős november eleji fagy és hótakaró esetén a rajzás szünetel, de felmelegedés után decemberben, sőt gyakran még januárban folytatódik. A repülés optimális hőmérséklete 5$10{ }^{\circ} \mathrm{C}$ (Tóth, 1999). A lepkék napközben kelnek ki, a hímek aktivitása naplemente után kezdődik és kb. éjfélig tart. A hímek a mesterséges fényt tömegesen keresik fel, alacsony légnyomás esetén a rajzás intenzitása sokszorosára nő. A szárnycsonkos nőstények éjjeli és kora reggeli órákban hagyják el a bábokat, gyalogolva igyekeznek a legközelebbi fatörzshöz, amelyen felfelé haladva a koronába jutnak. A hímek a fa törzse körül repkednek, és ott keresik fel a törzsön felfelé mászó, vagy még az avarlevelek között lévő röpképtelen nőstényeket, és megindul a párzásuk. A kopula több óráig tart, utána a hím 2-3, a nőstény 8-9 napig él (Győrfi, 1957). Egyegy nőstény által lerakott peték száma 200-300 is lehet. Felfelé ívelő gradáció esetében ez a peteszám 450-500-ig emelkedhet, majd a gradáció összeomlása után ismét az alacsonyabb értékre száll vissza (Mészáros, 1993a). A megtermékenyített nőstények a fák koronájában általában a rügyek közelében, a rügypikkelyek közé helyezik el petéiket egyesével, vagy 2-3 petéből álló kisebb csoportokban.

A hosszú meleg ősz ismétlődő esőkkel elősegíti az elszaporodásukat. A lepkék rajzása szempontjából fontos, hogy az esti órákban kedvező meleg és kissé csapadékos időjárási körülmények uralkodjanak. Ezzel szemben előnytelen számára a hideg, csapadékos tavasz, ami a gradáció összeomlását eredményezheti (Szontagh, 1980), a késő tavaszi fagyok pedig jelentős lárvapusztulást okozhatnak. A tömegszaporodást és a rajzásmenetet is jól jelzi a fénycsapdákra szívesen repülő szárnyas hímek egyedszámának fokozatos növekedése. Rajzásuk erdőben 5-7 nappal korábban kulminál, mint gyümölcsösökben (Kovács, 1962). A gradációja nagyon intenzív és ciklikus, viszonylag rövid ideig tart (Schwerdtfeger, 1969), Magyarországon általában 3-5 évig (Szontagh, 1980). A fénycsapda-adatok szerint tömegszaporodása 10-11 évenként 
ismétlődik. Az araszolók okozta tarrágásokban az O. brumata domináns faj, általában tölgyesekben, gyertyános-tölgyesekben szaporodik el tömegesen, és gyümölcsösökben is jelentős károkat okozhat (Mészáros, 2007). Gradációja komolyabb károkat okoz a hegyvidéki erdők nyírfáiban az északibb földrajzi szélességeken (Bylund, 1999).

2. Táblázat Operophtera brumata (Linnaeus, 1758) életciklusa

\begin{tabular}{|c|c|c|c|c|c|c|c|c|c|c|c|c|}
\hline & I. & II. & III. & IV. & V. & VI. & VII. & VIII. & IX. & X. & XI. & XII. \\
\hline Pete & $* * * *$ & $* * * *$ & $* * * *$ & & & & & & & $* * *$ & $* * * *$ & $* * * *$ \\
\hline Lárva & & & $* * * *$ & $* * * *$ & $* *$ & & & & & & & \\
\hline Báb & & & & & $* *$ & $* * * *$ & $* * * *$ & $* * * *$ & $* * * *$ & $* * * *$ & $* * *$ & \\
\hline Imágó & & & & & & & & & & $* * * *$ & $* * * *$ & $* * * *$ \\
\hline
\end{tabular}

\section{A nagy téliaraszoló (Erannis defoliaria Clerck, 1759)}

A nagy téliaraszoló holomediterrán fauna elem, quercetalis (tölgyön élö) faj. Megtalálható egész Európában és Elö-Ázsiában, de behurcolták Kanadába is. Dél-Európában csak a hegyvidékeken fordul elő. Magyarországon országszerte előfordul, egyes években rendkívül magas az egyedszáma (Kovács, 1962). Hernyója a lombos fákon polifág. Időnként erdészeti és kertészeti kártevő lehet. Jelentősége kisebb, mint a kis téliaraszolónak (O. brumata), bár jóval nagyobb és jó étvágyú a hernyója. Tápnövényei közé tartozik az összes lágymagvú, csonthéjas és bogyótermésű gyümölcsfaj az őszibarackot kivéve: a dió (Juglans), a mogyoró (Corylus), a gesztenye (Castanea) és majdnem minden erdei lombos fa és cserje is, így a tölgy (Quercus), a gyertyán (Caprinus), a szil (Ulmus), a bükk (Fagus), a hárs (Tilia), a nyár (Populus), a berkenye (Sorbus), a galagonya (Crataegus) és a vadrózsa (Rosa spp.) (Reichart, 1955).

A lepkénél nagyfokú ivari kétalakúság figyelhető meg. A nőstény szárnytalan, pöttyös és nincs farpamacsa. A lepke késő ősszel, októbertől decemberig rajzik (3. táblázat). Univoltin, tehát évente csak egy nemzedéke van. E faj pete formában telel át.

A késő ősszel, tél elején lerakott petékből az időjárástól függően a fiatal, araszolva mászó hernyók néhány nappal később, mint a kis téliaraszoló (O. brumata L.), március elején kezdenek megjelenni, és április folyamán bújnak elő. A peték hosszanti végét rágják ki, és ezen a nyíláson át távoznak, de a pete héját nem falják fel.

A frissen kibújt hernyók kb. 25-30 cm hosszú selyemszálon leereszkednek, majd a tavaszi széllökések hatására utána eresztik a selyemfonalat, és így egyre hosszabb fonál végén csüngnek. Amikor olyan hosszú a fonál, hogy az újabb széllökést nem tudja elviselni, elszakad, és a kis hernyó a fonál segítségével tovavitorlázik. Így terjed a faj tovább. A szél erősségétől függően nagyobb távolságot is legyőzhetnek a „repülő” hernyók. Egy hernyó 1,5km távolságra is eljuthat. (Reichart, 1950). A lárvastádium hosszú ideig tart. A fiatal hernyók a rügyeket, 
később a virágokat, leveleket rágják. A leveleket nem szövik össze, kezdetben csak lyuggatgatják őket, később már képesek az erősebb erek elrágásra is, sőt a gyümölcskezdeményeket is kilyuggatják. Tápanyagszükségletük 2,5-3-szor nagyobb, mint a kis téliaraszolóé. Naponta 30-35-ször táplálkoznak. Nyugalmi helyzetben az ágakon pihennek kinyújtózva, vagy íj formában.

Május elejére már teljes pusztítást végeznek, miközben 5 fejlődési stádiummal 30-35 nap alatt kifejlődnek, és május közepe tájáig a talajba húzódnak (Reichart, 1955). Itt a talaj 12-15 cm mélységében, szövedék, gubó nélküli kis földüregben egy ideig előbábként fekszenek, majd bábbá alakulva a számukra kedvezőtlen nyári hónapokat a talajban diapauzálva vészelik át.

Csak a hideg idő beálltával a ködös, zimankós őszi estéken jelennek meg a lepkék. Rajzásuk rendszerint októberben kezdődik, de januárig is eltarthat. A lepkék kikeléséhez csapadék szükséges. Ez az oka annak, hogy egy esős ősz erőteljesebb rajzás veszélyét hordozza magában. A kikelő hernyók számát jelentősen csökkentik a kora tavaszi fagyok. A szürkületben kelő nőstények a fatörzseken gyorsan másznak felfelé, és körülbelül 4-5 méter magasban várnak a hímekre. A hím lepkék a teljes besötétedés után kezdenek repülni, és a fatörzseken felfelé mászó nőstényeket felkeresve a fatörzsön kopulálnak, mely sokszor még a délelőtti órákba is belenyúlhat. Ilyenkor mindig a nőstény helyezkedik el fejjel felfelé, a hím pedig a talaj irányába tekint. A párzást követően a megtermékenyített nőstények felmásznak a fakoronába, ahol rügyek közelébe (mellé vagy ágelágazásokba) helyezik el petéiket. Közben gyakran belefagynak az ágat borító jégrétegbe, de nem pusztulnak el, hanem a következő napi felmelegedéskor továbbmásznak, és folytatják a peterakást. Ez többször is megismétlődhet. Egy nőstény alkalmanként körülbelül 300-400 petét rak le (Tóth, 1999). A gradáció lappangó időszakában nőstényenként 200-340 petét raknak, a gradáció kitörése előtt emelkedik a peteszám, ilyenkor már 440-840 is lehet (Reichart, 1993a). A kitörés után a peteszám ismét csökken. Az embrionális fejlődés a tavasz beköszöntével ismét megindul és a hőmérsékleti viszonyoktól függően a peterakástól számítva 50-127 napig tarthat.

Populációdinamikája elég szabályos, 10-12 évente lehet gradációra számítani, száraz évek után (Tóth, 1999). A tömegszaporodásukat elindító okokat pontosan nem ismerjük, de az időjárási tényezők valószínűleg jelentős szerepet játszanak benne. Tömeges elszaporodása a gyertyánnal elegyes erdőkben indul meg, ahol kora tavasszal a gyertyánon kikelő és megerősödő hernyók a tölgyre átjutva folytatják a táplálkozásukat, mely gyakran a tarrágás fokozatot is eléri. Gradációs csúcsai 1950-ben, 1962-ben, 1974-ben, 1982-ben, valamint 1995-ben voltak (Tóth, 1999).

Ezekben az években a második leggyakoribb faj volt. A rajzáscsúcs a fénycsapda-adatok szerint 1961-ben november 8. és 12. között kulminált (Kovács, 1962). Főleg domb- és 
hegyvidéken volt jelentős egyedszámmal jelen, síkvidéken ritkábban lehetett vele találkozni. Gradációja 3-5 évig tart. Az előrejelzés érdekében október elején a fákra felkötött hernyófogóövek megfigyelésével nyerhetünk adatokat az egyedszámáról. Ha a hernyóöveken sok szárnyatlan nőstény gyülik össze, vagy ha a fénycsapdák sok szárnyas hímet fognak, akkor a következő év tavaszára be kell tervezni a védekezést (Reichart, 1993a). A gradáció utolsó szakaszában az éhségtől legyengült hernyókat vírusok, baktériumok, rovarpatogén gombák támadják meg. Tömeges elpusztulásukat leginkább a száraz évek után tapasztalták (Leskó et. al. 1998).

3. Táblázat Erannis defoliaria (Clerck, 1759) életciklusa

\begin{tabular}{|c|c|c|c|c|c|c|c|c|c|c|c|c|}
\hline & I. & II. & III. & IV. & V. & VI. & VII. & VIII. & IX. & X. & XI. & XII. \\
\hline Pete & $* * * *$ & $* * * *$ & $* *$ & & & & & & & & $* * * *$ & $* * * *$ \\
\hline Lárva & & & $* * *$ & $* * * *$ & $* *$ & & & & & & & \\
\hline Báb & & & & & $* *$ & $* * * *$ & $* * * *$ & $* * * *$ & $* * * *$ & $* * *$ & & \\
\hline Imágó & & & & & & & & & & $* * * *$ & $* * * *$ & $* * * *$ \\
\hline
\end{tabular}

\section{A tollascsápú araszoló (Colotois pennaria Linnaeus, 1761)}

A tollascsápú araszoló a lepkék rendjének araszolólepkék (Geometridae) családjába tartozó faj. Holomediterrán faunaelem. Elsősorban Közép- és Dél-Európában, Örményországban, Kis-Ázsiában terjedt el (Bergmann, 1955). Magyarországon mindenütt előfordul, főleg sík- és dombvidéken gyakori. Lombos fákon (lombkorona-szintben) polifág, ritkás erdőkben, de esetleg gyümölcsösökben is (Koch, 1961) megtalálható. Fő tápnövényei a gyertyán (Caprinus), kocsánytalan tölgy (Quercus petraea), a hárs (Tilia), a nyár (Populus), a nyír (Betula), a füz (Salix), valamint a kökény (Prunus spinosa).

A lepke szeptember közepe táján jelenik meg, és novemberig rajzik (4. táblázat). Napközben a sárguló lombkoronában, ritkábban a fatörzsön pihen, nem táplálkozik. A nőstény a petéket csoportosan, ritkán az egészet egy csomóba, a fa koronájában rügyek mellé, ágakra rakja. A gradáció időszakában 80-400, átlagosan 250 petét rak le. Petecsomói telelnek át. A hernyók rügyfakadáskor kelnek ki, és nagyon mozgékonyak, kezdettől fogva egyesével táplálkoznak, először a rügyeken, majd a leveleken. Eleinte lyuggatják a leveleket, később az egészet elfogyasztják. Kinyújtózkodva, mereven pihennek az ágakon, ilyenkor száraz ág látszatát keltik (mimikri). A hernyóik 1-2 héttel később bábozódnak, mint az O. brumata. Fejlődésük június elején fejeződik be, ekkor leereszkedik a talajra, a felső néhány centiméteres rétegben földgubót készít, és ebben bábozódik. A nyarat a báb nyugalomban tölti (Mészáros, 1993b).

A lepkék döntően naplemente után aktívak, de borús időben már a délutáni órákban is mozoghatnak. Mindkét ivar egyaránt jól repül, mesterséges fényforrásokra is. 
Tömegszaporodása tölgyesekben, gyertyános tölgyesekben a leggyakoribb. Magyarországon az Északi-Középhegységben tömeges elszaporodása rendszerint 7-10 évenként következik be.

Nagy mennyiségben rajzott 1961-ben, és 1970-ben (Szontagh, 1977). A 70-es években országszerte nagyobb egyedsürüséget mutatott, mint korábban.

A tollascsápú araszoló tömeges elszaporodása esetén tarrágást is okozhat. A téliaraszoló csoport egyik tagjaként általában a többi téliaraszolóval együtt okoz érzékeny rágást. Egyedszáma a többi téliaraszolóhoz viszonyítva alacsonyabb, ugyanakkor meleg, száraz délidélnyugati kitettségekben domináns faj is lehet. Az erdészeti fénycsapdák 1961 és 1998 között öt alkalommal fogták tömegesen. A bejelentett kártételek alapján szintén 5 alkalommal okozott érzékeny rágást a téliaraszoló csoport tagjaként. 1994-ben a Börzsöny-hegységben domináns faj volt. Az erdészeti fénycsapdák adatai alapján megállapítható, hogy a Dunántúlon és az Alföldön egyedszáma kisebb volt, mint az Északi-középhegységben.

A fiatal hernyók hideg esős időjárás esetén tömegesen elpusztulnak, ami a gradáció összeomlását eredményezheti.

4. Táblázat Colotois pennaria (Linnaeus, 1761) életciklusa

\begin{tabular}{|c|c|c|c|c|c|c|c|c|c|c|c|c|}
\hline & I. & II. & III. & IV. & V. & VI. & VII. & VIII. & IX. & X. & XI. & XII. \\
\hline Pete & $* * * *$ & $* * * *$ & $* *$ & & & & & & & $* * * *$ & $* * * *$ & $* * * *$ \\
\hline Lárva & & & $* *$ & $* * * *$ & $* * * *$ & $*$ & & & & & & \\
\hline Báb & & & & & & $* * *$ & $* * * *$ & $* * * *$ & $* * *$ & & & \\
\hline Imágó & & & & & & & & & $* *$ & $* * * *$ & $* *$ & \\
\hline
\end{tabular}

\section{Az aranysárga téliaraszoló (Erannis aurantiaria Hübner, 1799)}

Az aranysárga téliaraszoló, a lepkék rendjének araszolólepkék (Geometridae) családjába tartozó faj. Holomediterrán faunaelem. Európában és Elő-Ázsiában lombos erdőkben mindenütt elterjedt faj. Lombkorona-szintben polifág, minden lombos fán és cserjén megtalálható. Erdökben mindig foltokban, esetleg gyümölcsösökben is. Tápnövényei elsősorban a gyertyán (Carpinus), a tölgy (Quercus), a nyír (Betula), a hárs (Tilia), valamint a bükk (Fagus).

A lepke október végétől decemberig (a fagyokig) rajzik (5. táblázat). A szárnyas hímek az esti órákban keresik fel a fatörzsön mászó szárnycsonkos nőstényeket, és még lehetőleg a fatörzsön párosodnak. A kopuláció után a nőstény 120-200 petét rak le a fa törzsére, kéregrepedésekbe. Pete alakban telel át. A hernyók áprilisban lombfakadás idején kelnek ki a peterakástól átlagosan 126 nap múlva. Kikelés után selyemszálakon lógnak, és a szél segítségével terjednek. Eleinte a rügyeket rágják ki, majd a virágbimbókat, végül a kifakadt lombleveleket rágják le. Öt lárvastádiumuk van. Általában 45 nap alatt fejlődnek ki. Kifejlődésük után selyemszálon leereszkednek a talajra és ott a talajtól függően 5-6 cm mélyen üreget készítenek, amelyben néhány laza selyemszálat feszítenek ki, és ott bábozódnak. A báb 
egész nyáron nyugalomban marad. November első harmadában távozik az imágó a bábból, mintegy 200 napos nyugalom után. A talajból nem a báb, hanem az imágó egy 4,5 mm átmérőjü, kissé kanyargós csatornán keresztül halad a felszínre. A bábing a csatorna alján marad a talajban (Reichart, 1993b).

A téliaraszoló fajok egyike, kártétele a többi araszoló hernyóval együtt lehet jelentős, többnyire szórványos, járulékos faj. Tömegszaporodásakor az egyedszáma általában jóval kisebb, mint az O. brumata, E. defoliaria, C. pennaria fajoké. Az erdészeti fénycsapdák adatai szerint leggyakrabban az Északi-Középhegységben fordul elő nagyobb egyedszámban. Magyar fénycsapdaadatok szerint tömegszaporodása a többi téliaraszolóval esik egybe (Reichart, 1993b).

5. Táblázat Erannis aurantiaria (Hübner,1799) életciklusa

\begin{tabular}{|c|c|c|c|c|c|c|c|c|c|c|c|c|}
\hline & I. & II. & III. & IV. & V. & VI. & VII. & VIII. & IX. & X. & XI. & XII. \\
\hline Pete & $* * * *$ & $* * * *$ & $* * * *$ & & & & & & & & & $* * * *$ \\
\hline Lárva & & & & $* * * *$ & $* * * *$ & $* * * *$ & $* * * *$ & & & & & \\
\hline Báb & & & & & $* *$ & $* * * *$ & $* * * *$ & $* * * *$ & $* * * *$ & $* * * *$ & & \\
\hline Imágó & & & & & & & & & & $*$ & $* * * *$ & $*$ \\
\hline
\end{tabular}

\section{A gyakori apróaraszoló (Idaea dimidiata Hufnagel, 1767)}

Holomediterrán faunaelem, euryök faj (Varga et al., 2004). Elterjedését tekintve szinte egész Európában megtalálható, egészen Kis-Ázsiáig. Élőhelye főként kertek, tisztások, erdőszegélyek, ligetek, bozótos hegyi legelők. Magyarországon országszerte előfordul, de csak nedves helyeken, főleg lápokban (Kovács, 1965). Gyakoriságát tekintve szórványos és általában nem gyakori. Gyepszintben polifág. Tápnövénye elsősorban a földre hullott száraz levelek, fonnyadt füvek, avar, korhadék (Reichholf-Riehm, 1996).

A lárva stádium szeptembertől májusig tart, hernyó alakban telelnek (6. táblázat). Az imágó június végétől szeptember végéig repül (Koch, 1961).

6. Táblázat. Idaea dimidiata (Hufnagel, 1767) életciklusa

\begin{tabular}{|c|c|c|c|c|c|c|c|c|c|c|c|c|}
\hline & I. & II. & III. & IV. & V. & VI. & VII. & VIII. & IX. & X. & XI. & XII. \\
\hline Pete & & & & & & & & $* * * *$ & $* * * *$ & $* * * * *$ & & \\
\hline Lárva & $* * * *$ & $* * * *$ & $* * * *$ & $* * * *$ & $*$ & & & & & $* * * *$ & $* * * *$ & $* * * *$ \\
\hline Báb & & & & $* * * *$ & $* * * *$ & $* * * *$ & $*$ & & & & & \\
\hline Imágó & & & & & & $*$ & $* * * *$ & $* * * *$ & $* * * *$ & & & \\
\hline
\end{tabular}

\section{A feketepettyes araszoló (Scopula nigropunctata Hufnagel, 1767)}

Euro-szibériai faunaelem, mezofil faj (Varga et al., 2004). Közép- és Dél-Európában, Kis-Ázsiában és Iránban gyüjtötték, állítólag Kínában is előfordul. Közép- és Észak-Európában elterjedt, és gyakori a füves, bozótos helyeken és a világosabb lomberdők-, elegyeserdők 
peremén, nedves szurdokokban, lápos, mocsaras területeken, kertekben, parkokban (Fajčik, 2003). Magyarországon mindenfelé fogták, de csak szükre szabott területeken, leginkább lápok környékén (Kovács, 1965). Gyepszintben és cserjeszintben polifág. A lepkék júniustól augusztusig repülnek. A lárva stádium augusztustól júniusig tart. Hernyó formában telel át (7. táblázat). Ősszel, illetve tavasszal útifüvön (Plantago), tisztesfüvön (Stachys), veronikán (Veronica), ibolyán (Viola), bükkönyön (Vicia), loncon (Lonicera), valamint égeren (Alnus) és mogyorón (Corylus) is él (Koch, 1961).

7. Táblázat Scopula nigropunctata (Hufnagel, 1767) életciklusa

\begin{tabular}{|c|c|c|c|c|c|c|c|c|c|c|c|c|}
\hline & I. & II. & III. & IV. & V. & VI. & VII. & VIII. & IX. & X. & XI. & XII. \\
\hline Pete & & & & & & & $* * * *$ & $* * * *$ & $* * * *$ & & & \\
\hline Lárva & $* * * *$ & $* * * *$ & $* * * *$ & $* * * *$ & $* * * *$ & $* *$ & & $* * * *$ & $* * * *$ & $* * * *$ & $* * * *$ & $* * * *$ \\
\hline Báb & & & $* * * *$ & $* * * *$ & $* * * *$ & $* * *$ & & & & & & \\
\hline Imágó & & & & & & $* * * *$ & $* * * *$ & $* * * *$ & & & & \\
\hline
\end{tabular}

\section{A nagy tarkaaraszoló (Pelurga comitata Linnaeus, 1758)}

Euro-szibériai faunaelem, silvicol faj (Varga et al., 2004). A kopár és elhanyagolt (ruderális) területeken elterjedt, előfordulása mezők határában, utak mentén, erdőszéleken, kertekben gyakori. A korábbi tapasztalatok szerint tipikusan a gyomos és félkúltur területek lepkéje. Főbb tápnövényei a labodafélék (Atriplex), libatopfélék (Chenopodium), ürömfélék (Artemisia). A hernyóikkal augusztus-szeptember táján találkozhatunk, majd báb stádiumban telelnek át (8. táblázat). Az imágó júniustól szeptemberig repül (Koch, 1961).

8. Táblázat Pelurga comitata (Linnaeus, 1758) életciklusa

\begin{tabular}{|c|c|c|c|c|c|c|c|c|c|c|c|c|}
\hline & I. & II. & III. & IV. & V. & VI. & VII. & VIII. & IX. & X. & XI. & XII. \\
\hline Pete & & & & & & & $* * * *$ & $* * * *$ & & & & \\
\hline Lárva & & & & & & & & $* * * *$ & $* * * *$ & & & \\
\hline Báb & $* * * *$ & $* * * *$ & $* * * *$ & $* * * *$ & $* * * *$ & $*$ & & & & $* * * *$ & $* * * *$ & $* * * *$ \\
\hline Imágó & & & & & & $* * * *$ & $* * * *$ & $* * * *$ & $* *$ & & & \\
\hline
\end{tabular}

\section{A sárga galajaraszoló (Eulithis pyraliata Denis \& Schiffermüller, 1775)}

Euro-szibériai faunaelem, mezofil faj (Varga et al., 2004). Nedves területektől a száraz, napos, nyílt területekig mindenhol előfordul, gyepszintben jellemző, gyakori faj. Hegyi réteken, bokor-erdőkben, erdőszéleken, mocsaras területen, kertekben elterjedt. Tápnövénye a galaj (Galium spp.), valamint a müge (Geum). Az imágó júniustól augusztusig repül. A lárva stádium májustól júniusig tart (9. táblázat). Pete formában telel (Koch, 1961). 
9. Táblázat Eulithis pyraliata (Denis \& Schiffermüller, 1775) életciklusa

\begin{tabular}{|c|c|c|c|c|c|c|c|c|c|c|c|c|}
\hline & I. & II. & III. & IV. & V. & VI. & VII. & VIII. & IX. & X. & XI. & XII. \\
\hline Pete & $* * * *$ & $* * * *$ & $* * * *$ & $* * * *$ & & & & $* * * *$ & $* * * *$ & $* * * *$ & $* * * *$ & $* * * *$ \\
\hline Lárva & & & & & $* * * *$ & $* * * *$ & & & & & & \\
\hline Báb & & & & & $* *$ & $* * * *$ & $* *$ & & & & & \\
\hline Imágó & & & & & & $* * * *$ & $* * * *$ & & & & & \\
\hline
\end{tabular}

Több külföldi kutató is vizsgálta a téli araszolók populációdinamikáját (Kula, 2002, Kula et al., 2006, Tomescu and Netoiu, 2006, Jepsen et al., 2008, Glavendekić, 2010, Salvadori and Maresi, 2008).

A globális felmelegedés változásokat eredményezett Észak-Skandinávia szubartikus nyírerdei ökoszisztémájában. A klímaváltozás befolyásolta az $O$. brumata gradáció dinamikáját az elmúlt 20 évben és a faj markáns észak-keleti írányú terjedését tapasztalták (Jepsen et al., 2008).

Romáiában az erdészeti kártevők között is a legveszélyesebbek közé sorolják a téli araszolók közül az O. brumata és az E. defoliaria fajokat. Egy 2005-ben végzett felmérés szerint a kontinentális éghajlatú tölgyesekben az egyre szárazabb és melegebb időjárás következtében 510 évente számíthatnak ismételt gradációkra. 


\section{CÉLKITÜZÉS}

Az araszolólepkék populációdinamikai vizsgálatainak a feljegyzett kártételek alapján kiemelt jelentősége van a növényvédelemben mind az erdők, mind pedig a gyümölcsfák védelmének kutatásai terén. E lepkecsoport néhány faja a legnagyobb területi tarrágásokat okozó rovarok közé sorolható. Ma már hosszú távú, bár az adatrögzítés szempontjából sajnos nem minden időszakban egységes szempontok szerint felvételezett adatsor áll rendelkezésünkre ezen lepkefajokat illetően az 1961-ben kiépült erdészeti fénycsapdahálózatnak köszönhetően. Fontosnak tartom ezen adatok feldolgozását és vizsgálatát a fajok jobb megismerése, valamint a jövőben várható változások feltérképezése céljából.

\section{A fentiek alapján az alábbi célkitüzéseket fogalmaztam meg:}

Az eddig rendelkezésre álló adatok és tudományos ismeretek birtokában 8 egynemzedékes Lepidoptera faj rajzásdinamikájának vizsgálata a klímaváltozás tükrében. Ezen belül:

1. A megfigyelt adatok alapján a rajzáskezdet és rajzáshossz időbeli alakulásának leírása, valamint klímamodellek alapján a rajzáskezdetek és rajzáshosszak eloszlásának jövőbeli várható módosulásának becslése;

2. Olyan fajspecifikus klímaindikátorrendszer kidolgozása, amely igazolhatóan szoros kapcsolatban áll a fajok rajzásdinamikájával;

3. Az éves egyedszámok alakulásának differenciaegyenleten alapuló populációdinamikai modellekkel való közelítése;

4. A kapott populációdinamikai modellek klímaindikátorokkal való bővítésével az egyedszám-becslések javítása;

5. A rendelkezésünkre álló időjárási paraméterek, illetve az azokból előállított klímaindikátorok függvényében a fajok populációdinamikájában, valamint az egyes populációk fenológiai történéseiben rejlő törvényszerüségek felkutatása, leírása.

6. Regionális klímamodell-becslések és a klimatikus indikátorok, valamint az azokkal bővített populációdinamikai modellek alapján a fajok várható egyedszámaira vonatkozó megállapítások megfogalmazása. 


\section{ANYAG ÉS MÓDSZEREK}

\subsection{A vizsgálat anyaga}

\subsubsection{Felhasznált alapadatok}

A hosszú távú meteorológiai adatsorok elengedhetetlenek a klímaváltozás mind a múltbeli, mind a jövőbeli hatásainak elemzéseihez.

A vizsgálathoz felhasznált lepkeadatok az Országos Erdészeti Fénycsapdahálózat azon 9 csapdájának gyüjtési eredményeiből származnak, amelyek 1962 és 2006 között a leghosszabb ideig működtek. A szóban forgó fénycsapdák az alábbi települések közelében találhatók: Felsőtárkány, Gerla-Gyula, Mátraháza, Répáshuta, Sopron, Szentpéterfölde, Tolna, Tompa, Várgesztes (3. ábra). A rendelkezésre álló inhomogén és sok helyen hiányos adatokat szüréssel és feldolgozással tettük összehasonlíthatóvá és elemezhetővé.

\section{ERDÉSZETI FÉNYCSAPDA HÁLÓZAT MAGYARORSZÁGON}

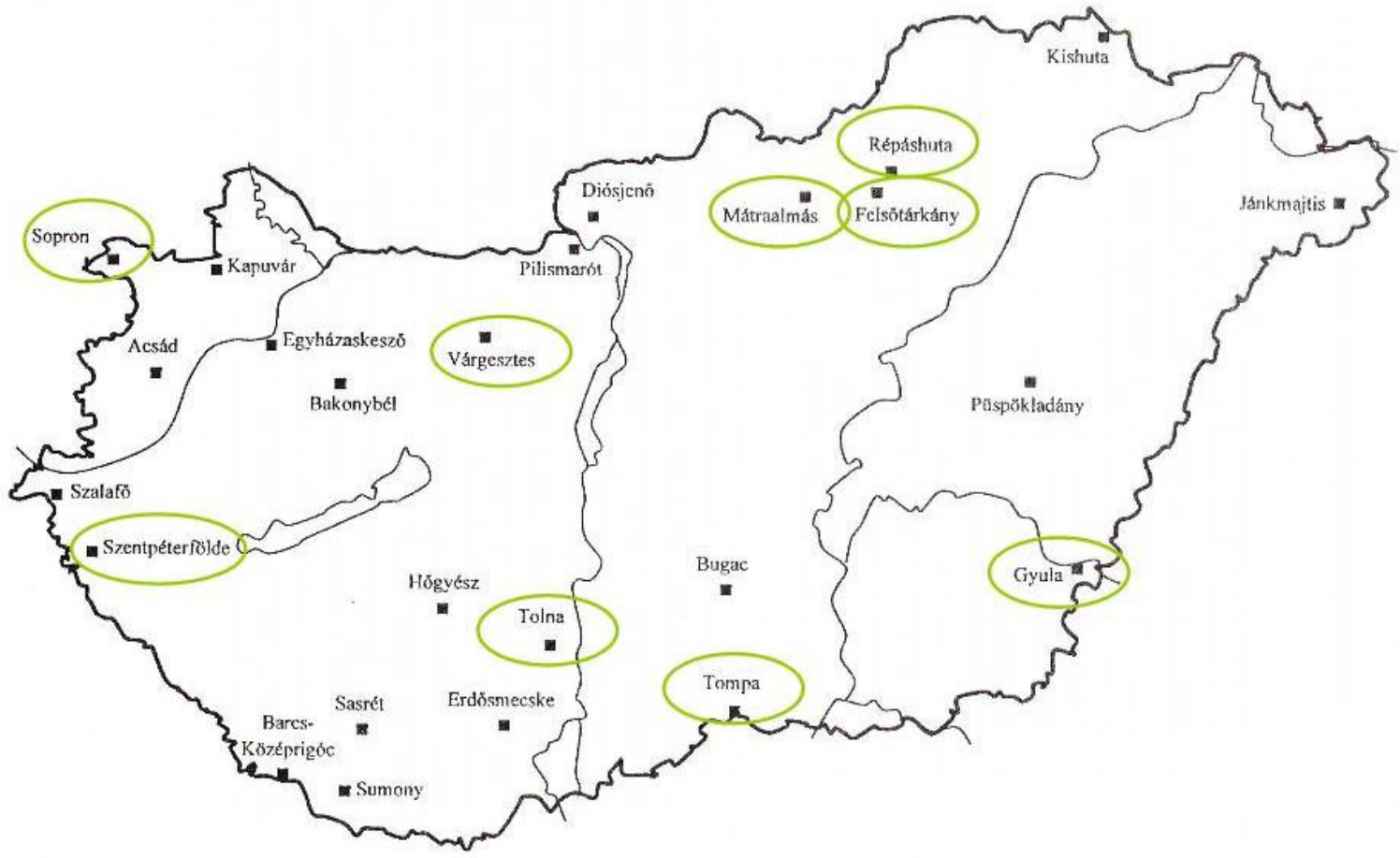

3. ábra A fénycsapdák területi eloszlása (a vizsgálatba bevont csapdák helyét karika jelzi) (forrás: a szerzö saját szerkesztése)

A vizsgálatba a fénycsapdák egységes felvételezésűnek tekinthető eredményeit vontuk be, s olyan univoltin araszoló (Geometridae) fajok adatait használtuk fel, amelyből mindegyik csapdában minden évben volt befogott példány. A lepkék rendjének az egyik legnagyobb fajszámú családjába tartozó négy erdészeti és kertészeti kártevő Lepidoptera fajt: kis téliaraszoló O. brumata (Linnaeus, 1758), nagy téliaraszoló E. defoliaria (Clerck, 1759), tollascsápú araszoló C. pennaria (Linnaeus, 1761), aranysárga téliaraszoló E. aurantiaria (Hübner, 1799) és továbbá 
négy nem kártevőt: nagy tarkaaraszoló P. comitata (Linnaeus, 1758), I. dimidiata (Hufnagel, 1767), S. nigropunctata (Hufnagel, 1767) E. pyraliata (Denis \& Schiffermüller, 1775) választottuk.

A 9 fénycsapdaállomáson a negyvenhat év alatt összesen O. brumata (L.) 144432 (hím), E. defoliaria (Clerck) 62753 (hím), E. aurantiaria (Hübn.) 24836 (hím), C. pennaria (L.) 32423, P. comitata (L.) 32426, I. dimidiata (Hufn.) 36837, S. nigropunctata (Hufn.) 27171, E. pyraliata (D. \& Schiff.) 45981 példányt gyüjtőttek a csapdák.

A meteorológiai adatok az Országos Meteorológiai Szolgálat (OMSZ) adatbázisából származnak. A meteorológiai állomások közül egy - Budapest mint kiemelt - állomás napi adataival dolgoztunk. A napi értékek az adatbázisban a középhőmérsékletet $\left({ }^{\circ} \mathrm{C}\right)$, a maximumhőmérsékletet $\left({ }^{\circ} \mathrm{C}\right)$, a minimumhőmérsékletet $\left({ }^{\circ} \mathrm{C}\right)$, a csapadékmennyiséget $(\mathrm{mm})$ tartalmazzák 1961. 01. 01. és 2000. 12. 31. között. (A kiválasztott csapdák az ország különböző pontjain találhatók, a köztük lévő területnek körülbelüli közepén Budapest van, ezért esett a választásom a meteorológiai adatokat illetően a budapesti meteorológiai állomásra.)

A klímaváltozás hatásainak vizsgálatához az ELTE Meteorológiai Tanszékének munkatársai által 10 km-es rácspontokra leskálázott, az 1961-90-es bázisidőszakhoz igazított, a 2021-2050, valamint 2071-2100 közötti időintervallumokra vonatkozó RegCM3.1 (regionális) klímamodell futtatásainak eredményeit használtuk fel, mely a SRES A1B klímaváltozási forgatókönyv feltételeit veszi alapul (Giorgi et al., 1993, Bartholy et al., 2009a, Torma et al., 2008).

\subsection{A vizsgálat módszerei}

\subsubsection{A csapdázási adatok feldolgozása}

A vizsgálatokhoz felhasznált rajzási adatok az Országos Erdészeti Fénycsapda Hálózat kilenc fénycsapdájának napi fogásaiból származnak 1962-2000 időintervallumra vonatkozóan.

A különböző abiotikus tényezők, valamint a különböző befogási helyeken fellépő, a befogás számát módosító hatások csökkentése érdekében célszerü volt az összes fénycsapda adatot egységesen felhasználni, amit mozgóátlag-számítással végeztünk el. A mozgóátlagszámítás 4 szomszéd, azaz 9 napi adat átlagának számolásával történt (9-ed rendü mozgóátlag ablakok), az alábbi képlettel (Nowinszky, 2003, Moon és Kim, 2007, Gimesi és Hufnagel, 2010):

$$
M_{k+4}=\frac{1}{n} \sum_{i=k}^{k+8} \sum_{j=1}^{9} d_{i, j},
$$

ahol: 
$d_{i j}=$ a csapda fogása (egyedszám), ahol $j$ a csapdák, $i$ a napok sorszáma (ha egy csapda nem müködött vagy nem volt fogás, értéke 0);

$n=\mathrm{a} 9$ nap alatt ténylegesen müködésben lévő csapdákból származó $d_{i j}$ adatok száma (az átlagba csak a müködésben lévő csapdák értékeit számoltuk bele);

$k=$ a 9 napos ablak kezdőnapja.

Az így kapott adatokból a rajzás kezdete az évi első, a rajzás vége a rajzás kezdetét követő utolsó nem nulla $M_{k+4}$ érték. A rajzás hossza a két érték különbsége.

\subsubsection{A rajzáskezdet és a rajzáshossz egymástól és a klimatikus viszonyoktól való függéseinek vizsgálata}

A lepkék évi rajzáskezdetének és rajzáshosszának egymástól, valamint a klimatikus viszonyoktól való függését vizsgáltuk. Ezen vizsgálathoz csak az egységes felvételezésünek tekinthető fajok eredményeit vontuk be. A rendelkezésünkre álló mintából a lepke rajzási adatainak, valamint a belölük számolt 11 éves mozgóátlagok alapján 1972-1988 között elöször az adott fajok rajzásának kezdete, illetve annak hossza közti összefüggéseket vizsgáltuk. (A rajzási adatok esetén azért számoltunk 11 napi átlaggal, mert a mozgóátlag számításánál több számmal is próbálkoztunk, de a simítás számát ahogy növeltük úgy a 11 tag esetében kaptunk nagyon markáns trendet.) Ezt követően a 17 éves időszakra logisztikus regressziót alkalmazva vizsgáltuk a rajzáskezdet és rajzáshossz tendenciáit. A statisztikai elemzéseket a PASW Statistics 18.0 számítógépes programcsomagot alkalmazva végeztük.

\subsubsection{Differenciaegyenleten és indikátoranalízisen alapuló populációdinamikai modellezés}

Vizsgálatunk során három modellel dolgoztunk:

1. alapmodell - az éves egyedszámok differenciaegyenleten alapuló populációdinamikai modell

2. klímaindikátorokkal bővített alapmodell

3. főkomponens analízissel bővített alapmodell

\section{Alapmodell}

Egy egyszerü, $\quad N_{t+1}=N_{t} * \exp \left(R_{\max } *\left(1-\frac{N_{t}}{K}\right)^{\theta}\right) \quad$ alakú $\quad$ Ricker-típusú diszkrét differenciaegyenlet-modellből indultunk ki, ahol $R_{\max }$ a maximális növekedési rátát, $K$ az eltartókapacitást, $\theta$ a sebességi tényezőt, $N_{t}$ a $t$-edik évi, a 4.2.1 pontban leírt mozgóátlag- 
számítással korrigált megfigyelt egyedszámot, az $N_{t+1}$ pedig a következő év $(t+1)$ korrigált megfigyelt egyedszámát jelöli. (A továbbiakban ezeket röviden egyedszámnak fogjuk nevezni.) Ez a modell egy nem lineáris általánosítása a klasszikus logisztikus modellnek (Ricker, 1954, Verhulst, 1838, Richards, 1959, Nelder, 1961, Gilpin és Ayala, 1973, Berryman, 1999). Az $R_{t}=\ln \left(\frac{N_{t+1}}{N_{t}}\right)$ jelölést bevezetve modellünket a következő alakban írtuk fel:

$$
R_{t}=\ln \left(\frac{N_{t+1}}{N_{t}}\right)=R_{\max } *\left(1-\frac{N_{t}}{K}\right)^{\theta}=R_{\max }-R_{\max }\left(\frac{1}{K}\right)^{\theta} N_{t}^{\theta} .
$$

Megjegyezzük, hogy olyan populáció esetén, ahol nincs forráskorlátozás, vagyis az eltartó képesség $(K)$ hatalmas és a sebességi tényező $(\theta)$ kicsi, $\left(\frac{1}{K}\right)^{\theta} \approx 1$. Ekkor át tudjuk írni a fenti képletet az

$$
R_{t}=R_{\max }-R_{\max }\left(\frac{1}{K}\right)^{\theta} N_{t}^{\theta}=R_{\max }-a N_{t}^{\theta}
$$

alakba, ahol az $a=R_{\max }\left(\frac{1}{K}\right)^{\theta}$

\section{Matematikai modell kalibrálása}

A hibát a legkisebb eltérésnégyzetösszeggel (Root Mean Square Error, RMSE) definiáltuk:

$$
R M S E=\sqrt{\frac{1}{n} \sum_{j}\left(N_{t}-N_{t, p r e d}\right)^{2}},
$$

ahol az $n$ jelöli az évek számát, $N_{t, \text { pred }}$ pedig a modell által a $t$-edik évre becsült egyedszámot.

Három paramétert optimalizáltunk a hiba minimalizálásával: a maximális növekedési rátát $\left(R_{\max }\right)$, az eltartó kapacitást $(K)$ és a sebességi tényezőt $(\theta)$. Az optimalizálást Palisade’s Risk Evolver-féle szoftverrel, innovativ genetikai algoritmussal végeztük. A módszer lényege, hogy ha egy adott paraméterszett esetén a hibatagot a paraméterek kis változtatásával már nem lehet tovább csökkenteni, akkor egy sztochasztikus elem segítségével ebböl a paraméterkörnyezetből pozitív valószínüséggel kimozdul az eljárás, így az nem akad el a lokális optimumoknál, hanem az összes lehetséges megoldások között keresi a minimális hibataghoz tartozó paraméterszettet, így képes megtalálni a globális optimális megoldást (Weise, 2009). Az olyan feladatoknál különösen elönyös ez, ahol azt sejtjük, hogy lehetnek lokális minimumok, melyekhez tartozó paraméterszett a globális minimum(ok)hoz tartozó paraméterszett értékeihez nincsenek közel. 


\section{Klimatikus idikátorok adathalmaza}

Az OMSZ megfigyelt napi adataiból klimatikus indikátorokat számoltunk. A $t$-edik év 365, illetve 366 napját dekádokra (10 napokra) osztottuk fel (a dekádok közel lefedik az egy hónapos intervallumot nagyobb elcsúszások nélkül) és kiszámoltuk:

- az i-edik dekád napi középhőmérsékleteinek átlagát (TATLt_i)

- az $i$-edik dekád napi minimumhőmérsékleteinek átlagát (TMIN $t \_i$ )

- az i-edik dekád napi maximumhőmérsékleteinek átlagát (TMAXt_i)

- az i-edik dekád napi csapadékmennyiségének átlagát (RAINt_i)

- az i-edik dekád napi minimumhőmérsékleteinek minimumát (TMINNt_i)

- az $i$-edik dekád napi maximumhőmérsékleteinek maximumát (TMAXXt_i).

Létrehoztunk havi klimatius indikátorokat is a $t$-edik évre vonatkozóan:

- a j-edik hónap napi középhömérsékleteinek átlagát (MTATLt_j)

- a j-edik hónap napi minimumhőmérsékleteinek átlagát (MTMINt_j)

- a j-edik hónap napi maximumhőmérsékleteinek átlagát (MTMAXt_j)

- a j-edik hónap napi csapadékmennyiségének átlagát (MRAIN $t \_j$ )

- a j-edik hónap napi minimumhőmérsékleteinek minimumát (MTMINNt_j)

- a j-edik hónap napi maximumhőmérsékleteinek maximumát (MTMAXXt_j)

(1-12. melléklet).

Kiszámoltuk a Pearson-féle korrelációs együtthatót $(r)$ az $R_{t}=\left(\ln \left(\frac{N_{t+1}}{N_{t}}\right)\right)$, az $N_{t+1}$ és az $I_{t}$ és $I_{t+1}$ klimatikus indikátorok $(t=1962, \ldots, 2000)$ között. A Pearson-féle korrelációs együtthatót (r) a mintából az

$$
r=\frac{\sum_{i=1}^{n}\left(x_{i}-\bar{x}\right)\left(x_{i}-\bar{x}\right)}{(n-1) s_{x} s_{y}}
$$

számmal becsültük, ahol $\bar{x}$ és $\bar{y}$ a mintaátlagok, az $s_{x}$ és $s_{y}$ a korrigált tapasztalati szórások (Harnos és Ladányi, 2005). Azokat az indikátorokat, amelyek szignifikánsan magas korrelációt mutattak az egyedszámmal vagy annak változásával, leválogattuk, és az indikátor adatbázisból évenként létrehoztunk újabb oszlopokat, szám szerint 588-at:

- $\quad 6 * 37 * 2$ oszlop a dekádonkénti 6 típusból, 37 dekádra és 2 évre $\left(I_{t}\right.$ és $\left.I_{t+1}\right)$

- $6 * 12 * 2$ oszlop a havi indikátorok 6 típusából, 12 hónapra és 2 évre ( $I_{t}$ és $I_{t+1}$ ) 


\section{A modell fejlesztése}

Az OMSZ megfigyelt napi adataiból készített és a rovar fenológiai fázisaitól függő klimatikus igényeinek megfelelő klimatikus indikátorok lineáris kombinációit additív tényezőként a modellhez adva

$$
R_{t}=R_{\max }-R_{\max }\left(\frac{1}{K}\right)^{\theta} N_{t}^{\theta}+\sum_{k} C_{k} I_{k}
$$

alakban finomítottuk a modellt, ahol $I_{k}$ jelöli a klimatikus indikátorokat, $C_{k} \in \mathbf{R}$ pedig az optimalizálandó paramétereket.

Először csak egy klimatikus indikátort vettünk, azt amelyik leginkább korrelált az egyedszámmal vagy annak változásával. Ismét a fent definiált RMSE hibát minimalizáltuk az innovativ genetikai algoritmussal, a $3+1$ paraméter (maximális növekedési ráta $R_{\max }$, eltartóképesség $K$ és sebességi tényező $\theta$, valamint $C_{1}$ ) optimalizálásával. Majd stepwise módszerrel további klimatikus indikátor(oka)t vontunk be a modellbe. Újfent minimalizáltuk az RMSE hibát miközben a korábban már optimalizált paraméterekkel együtt az újonnan bevont indikátor együtthatóját is optimalizáltuk.

Minden lépésnél kiszámoltuk az Akaike információs kritériumot. A Bayes-féle korrekcióval dolgoztunk, mivel a paraméterek száma $(k)$ viszonylag nagy az esetek számához ( $n)$ képest $(n / k<40)$ (Turkheimer et al., 2003; Schwarz, 1978):

$$
A I C_{B}=n \ln \left(\frac{R M S E}{n}\right)+2 k+\frac{2 k(k+1)}{n-k-1},
$$

ahol $k$ a paraméterek száma, n pedig az évek száma.

Minden további lépésnél kiszámítottuk a determinációs együtthatót is, azaz a modell által magyarázott varianciahányadot:

$$
R^{2}=1-\frac{\sum\left(N_{t, \text { pred }}-N_{t}\right)^{2}}{\sum\left(N_{t}-\overline{N_{t}}\right)^{2}},
$$

ahol $N_{t}$ jelöli a megfigyelt értéket, $\overline{N_{t}}$ ezek átlagát, $N_{t, p r e d}$ pedig a modell által becsült értéket. A modell bővítését mindig a legerősebben korreláló, a már bevont indikátoroktól független új klimatikus indikátort bevonva addig folytattuk, amíg az Akaike információs kritérium Bayes-féle korrekciója el nem érte a minimumát.

\subsubsection{Főkomponens-regresszió}

A regresszióanalízis feladata, hogy valamely függvényszerü kapcsolatot keresünk egy függő változó és egy vagy több magyarázó változó között. A lineáris regressziós modell 
$Y=\beta_{0}+\beta_{1} * X+e$ alakban, az általános regessziós modell $Y=f(X)+e$ alakban írható fel, ahol $Y$ a függő változó, $X$ a független változó, a $\beta_{0}$ az egyenes tengelymetszete, a $\beta_{1}$ az egyenes meredeksége, $f$ egy tetszőleges függvény, míg az e a hibatag. A modell felírását követően az esetek többségében szükséges az értékeket pontdiagramon ábrázolni, mely segít a paraméterbecslésnél. A korrelációs együttható szignifikancia vizsgálata következik, amely null hipotézise szerint $X$ és $Y$ között nincs lineáris kapcsolat, az alternatív hipotézis pedig negatív vagy pozitív kapcsolatot feltételez a függő és a független változó közt. A vizsgálatára a $t$ statisztikát $n$-2 szabadságfokkal használjuk. Ezt követi a modellre vonatkozó ANOVA teszt, melyet $F$-statisztikával végzünk el. $F=\mathrm{MSreg} / \mathrm{MSrez}$, mely $F$ eloszlású és $p$-1 illetve $n$-2 szabadságfokú, ahol $p$ a becsült paraméterek száma. Az $Y$ érték elörejelzésének pontosságának becsléséhez hasznos a becslés standard hibáját kiszámítani, mely az $Y$ értékek szórása a becsült értékre. A becslés és annak standard hibájának hányadosára t-próbát végzünk. A regresszióanalízis egyik fontos feltétele az, hogy a magyarázó változók függetlenek egymástól, azaz nem lép fel kollinearitás. Ha ez a feltétel sérül, akkor felmerül az igény, hogy a regresszióanalízist megelőzően a magyarázó változókat úgy tömörítsük, hogy azok a regresszióanalízisre alkalmassá váljanak. Erre alkalmas módszer a főkomponens analízis (Harnos és Ladányi, 2005).

A főkomponens-analízis a többváltozós elemzéseknek egy olyan ún. dimenzióredukáló módszere, amely a kiindulási, nagyszámú, egymással erősen (de nem túl erősen) korreláló változókat azok lineáris kombinációjaként létrehozott mesterséges változók (főkomponensek) segítségével jelentősen kisebb számú változóba tömöríti. A főkomponensek konstrukciója során minden lépésben, úgy maximalizáljuk a változók lineáris kombinációja által magyarázott varianciát, hogy közben az egyes főkomponensek egymással korrelálatlanok maradnak. Ily módon az első főkomponens magyarázza a variancia legnagyobb részét, a második az első fökomponens által nem magyarázott (maradék) varianciahányad legnagyobb részét és így tovább. Az eredmények minél jobb áttekinthetősége érdekében a főkomponens analízist követően a változókat olyan térbeli forgatásnak vetjük alá, amelyben a komponensek súlyai vagy nagyok (abszolút értékeik egyhez közeliek), vagy kicsik (nullához közeliek). Mi az ún. varimax forgatást alkalmaztuk, mely biztosította, hogy a kapott komponensek korrelálatlanok maradjanak (Münnich et al., 2006, Naresh, 2005).

A fökomponens analízis módszerével összekapcsolt regresszióanalízist röviden fökomponens regressziónak nevezzük.

A statisztikai elemzéseket a SPSS 20, az optimalizálást a Palisade Optimizer számítógépes programok segítségével végeztük. 


\subsubsection{Jövőre vonatkozó becslések}

A klimatikus indikátoroknak a RegCM3.1 regionális klímamodell becslései alapján előállított értékei és a lepkék megfigyelt és a modellek által becsült egyedszámait összevetettük. $\mathrm{Az}$ indikátor- és fökomponens-analízisben kapott faktorok értékeit a RegCM3.1 regionális klímamodell 1961-1990-es, a 2021-2050-es és a 2071-2100-as időszeletekre prognosztizált eredményeivel is kiszámoltuk, és becsültük a várható egyedszámot.

\subsubsection{Statisztikai hipotézisvizsgálatok}

\section{Egymintás t-próba}

Az egymintás $t$-próbát a korrelációs, illetve determinációs együtthatók szignifikancia szint vizsgálatakor alkalmaztuk.

A próba a Student-féle $t$-statisztikán alapul. Az egymintás $t$-próba azon alapul, hogy egy mintában egy valószínűségi változó várható értéke szignifikánsan különbözik-e egy adott értéktől. A próba alkalmazásának feltételei, hogy a vizsgált valószínüségi változó (az alapsokaság) normális eloszlású, és a vizsgált valószínüségi változó intervallum vagy arányskálán mért legyen. A nullhipotézis alapján a vizsgált alapsokaság várható értéke statisztikai szempontból megegyezik az előre megadott értékkel (Harnos és Ladányi, 2005).

\section{Kétmintás t-próba}

Kétmintás $t$-próbát az indikátorok különböző idöintervallumban mért, illetve becsült értékeinek összehasonlítására használtunk.

A kétmintás t-próbát akkor alkalmazzuk amikor arra vagyunk kíváncsiak, hogy két véletlen mintában a két alapsokaság várható értékei egymástól szignifikánsan különböznek-e. A t-próba alkalmazásának feltételei: a vizsgált minták függetlenek, az alapsokaságok normális eloszlásúak, szórásaik megegyeznek. A t-próba nullhipotézise szerint a két vizsgált változó várható értéke statisztikai szempontból megegyezik. Hogy a két alapsokaság szórásnégyzete azonosnak tekinthetö-e, azt $F$-próbával tudjuk eldönteni (Harnos és Ladányi, 2005).

\section{Páros t-próba}

A különböző időszeletekre vonatkozó, rögzített egyedszámtól függő egyedszámbecslések várható értékeinek összehasonlítását páros $t$-próbával végeztük.

Páros $t$-próbát akkor alkalmazunk, ha a két véletlen mintánk ( $X$ és $Y$ ) nem független, hanem ellenkezőleg: valamely szempont szerint elemeik párosíthatóak. A próba során arra 
keressük a választ, hogy a két véletlen, nem független minta alapján elfogadható-e az a feltételezésünk, hogy a vizsgált két alapsokaság várható értéke megegyezik. A hipotézisek felírása, a feltételek ellenőrzése, a próbastatisztika számítása hasonlóan történik, mint a kétmintás $t$-próba esetében. A döntést a szignifikanciaszint alapján hozzuk meg (Harnos és Ladányi, 2005).

\section{Welch-próba}

Welch-próbát használtunk két normális eloszlású valószínűségi változó várható értékének összehasonlítására, amikor a varianciák azonosságának feltétele nem teljesült. A próba kevés feltételt használ, ezért igen gyenge próba, csak közelítő döntés hozható vele. A próba alkalmazásának feltétele hogy a vizsgált valószínűségi változók függetlenek és normális eloszlásúak legyenek. A próba nullhipotézise, hogy a két mintában a két várható érték statisztikai szempontból megegyezik (Harnos és Ladányi, 2005). 


\section{EREDMÉNYEK}

\subsection{A rajzáskezdet és a rajzáshossz egymástól, valamint a klimatikus viszonyoktól való függései}

A rajzáshossz-rajzáskezdet egymással való összefüggésének vizsgálata során a rajzáskezdet időpontja (Julianus nap) és a rajzáshossz (nap) között szignifikáns lineáris negatív korrelációt tudunk kimutatni, a kapott eredményeket a 10. táblázat tartalmazza.

10. táblázat. A rajzáshossz-rajzáskezdet egymással való korrelációja a vizsgált 8 faj esetében (1961-2006)

\begin{tabular}{|l|c|c|}
\hline \multicolumn{1}{|c|}{ FAJ } & $\begin{array}{c}\text { Pearson-féle } \\
\text { korrelációs együttható }(\boldsymbol{r})\end{array}$ & SL \\
\hline Operophtera brumata & $-0,896$ & $\mathrm{p}<0,01$ \\
\hline Erannis defoliaria & $-0,794$ & $\mathrm{p}<0,01$ \\
\hline Erannis aurantiaria & $-0,683$ & $\mathrm{p}<0,01$ \\
\hline Colotois pennaria & $-0,827$ & $\mathrm{p}<0,01$ \\
\hline Pelurga comitata & $-0,890$ & $\mathrm{p}<0,01$ \\
\hline Idaea dimidiata & $-0,701$ & $\mathrm{p}<0,01$ \\
\hline Scopula nigropunctata & $-0,709$ & $\mathrm{p}<0,01$ \\
\hline Eulithis pyraliata & $-0,450$ & $\mathrm{p}<0,01$ \\
\hline SL: szignifikancia limit & \multicolumn{2}{|}{}
\end{tabular}

A nyolc lepkefajt vizsgálva, mindegyikre elmondható, hogy az imágó minél későbbi megjelenésével, a rajzás ideje lerövidül.

A legszorosabb összefüggést az $O$. brumata, $P$. comitata és a $C$. pennaria fajoknál láthatjuk, míg a leggyengébbet az E. pyraliata mutatja.

Mit mutatnak a hosszú éves tendenciák a rajzáskezdet és rajzáshossz tekintetében? A vizsgált fajok közül, egyiknél sem mutatható ki markáns jellegü függvényszerü kapcsolat az évek és a rajzáskezdet, illetve a rajzáshosszra, ha az eredeti adatokat használjuk.

A téli araszolók (O. brumata, E. defoliaria, C. pennaria, E. aurantiaria) esetében, ha a 11 éves mozgóátlagokat tekintjük, hasonló rajzáskezdet és rajzáshossz mintázatot kapunk (4. ábra). A 10-11. táblázatban olvashatjuk a logisztikus, illetve a másodfokú modell paramétereinek becsléseit és statisztikai értékelését a négy kártevő rajzáskezdetének, valamint a rajzáshosszának tekintetében. Az E. defoliaria és a C. pennaria kb. 1972 és 1988 között hasonló logisztikus jelleget mutat (S-görbe). Valójában az O. brumata és az E. aurantiaria is, de e fajok esetében ez hosszabb időszakra (1987-95) jellemző. Az E. defoliaria és az O. brumata az első kb. 10, a $C$. pennaria, E. aurantiaria az első kb. 4 évben csökkenő, korábban kezdődő rajzáskezdettel és a $C$. pennaria kivételével ezzel növekvő rajzáshosszal jelentkezett. Ebből a négy fajból három, az $O$. brumata kivételével, az utolsó 6-8 évben erősen korábbra vonuló rajzáskezdetet, és ezzel megint hosszabb rajzáshosszt mutat. 
A E. pyraliata és a $S$. nigropunctata mintázata szintén hasonló egymással, de a téli araszolóktól merőben eltérő. A P. comitata markáns jegyeket visel, de mindegyik előző fajtól különbözöt. Az I. dimidiata-ra leginkább a mintázat nélküliség jellemzö. Az E. pyraliata és a $S$. nigropunctata a teljes vizsgált időszakra egyre korábbi rajzáskezdetet és egyre hosszabb rajzáshosszt mutat. A $P$. comitata a vizsgált időszakot körülbelül 1985-ben kettébontva először csökkenő majd növekvő logisztikus görbe szerint mutatja a rajzáskezdetet, és ennek megfelelően a rajzáshossz először növekvő, majd csökkenő logisztikus görbe szerint halad.

Az 1972-1988-as időintervallumra vonatkozóan a rajzáskezdetre és a rajzás hosszára $(Y)$ logisztikus modellt illesztettünk az idő ( $X$ [év]) függvényében (11-12. táblázat):

$$
Y=p_{1}+\frac{p_{2}-p_{1}}{1+\exp \left(-p_{3}\left(X-p_{4}\right)\right)}+e
$$

A $p_{1}, p_{2}, p_{3}, p_{4}$ a modell paramétereit, és az $e$ a normális eloszlású, zérus várható értékü hibatagot jelöli. A modell paraméterei a modell alábbi tulajdonságait mutatják:

$p_{1}=\lim _{-\infty} Y$;

$p_{2}=\lim _{+\infty} Y$;

$p_{3}=$ sebességi tényező, az inflexiós pontban vett érintő meredeksége: $p_{3} * \frac{p_{2}-p_{1}}{4}$;

$p_{4}=$ az infexiós pont helye az $X$ tengelyre vetítve.

Látható az eredményekböl, hogy az E. aurantiaria faj esetében a rajzáskezdetre a logisztikus modellünk kicsit korábbi rajzási időszakra írható fel 1969-1983-ig, a rajzáshosszra pedig másodfokú modellt illesztettünk:

$$
Y=p_{1}+p_{2} * X+p_{3} * X^{2}+e
$$

A 17 éves (1972-1988) időintervallumú vizsgálat során a rajzáskezdet és rajzáshossz logisztikus, illetve másodfokú illesztésünk eredményei a 4. ábrán láthatóak. 
RAJZÁSKEZDET
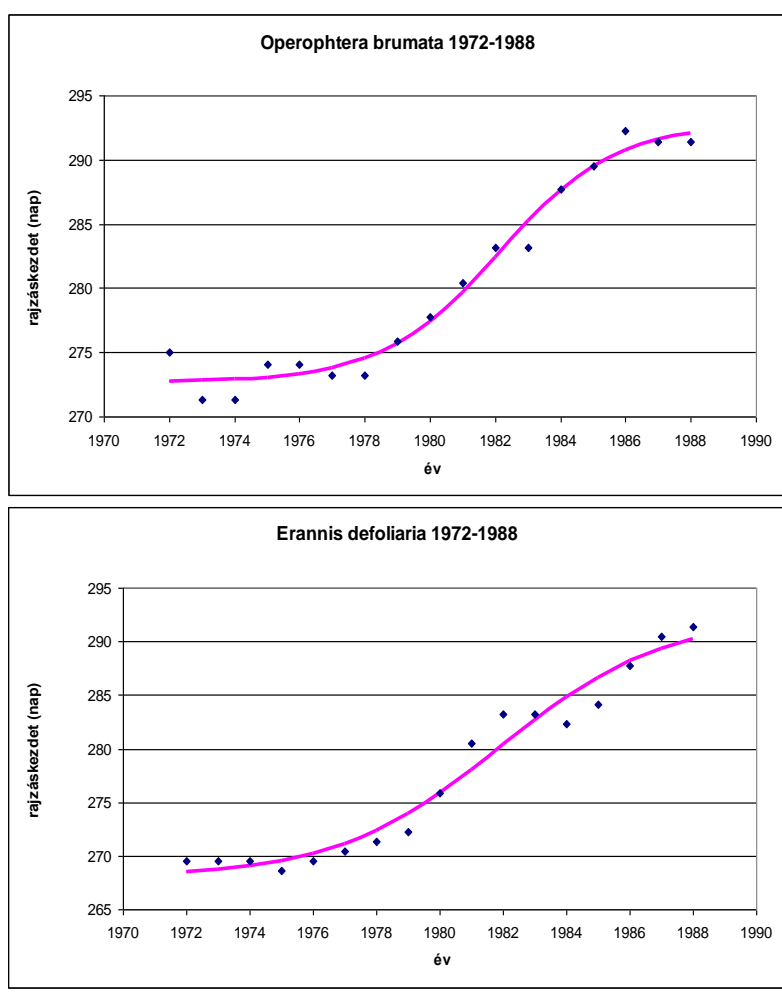

Colotois pennaria 1972-1988

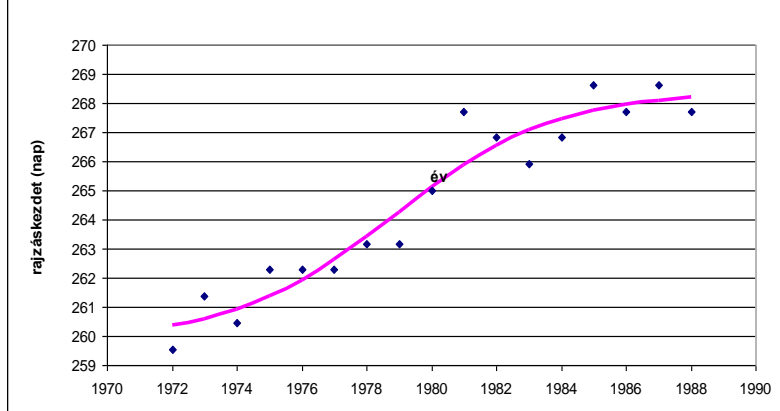

Erannis aurantiaria 1969-1983

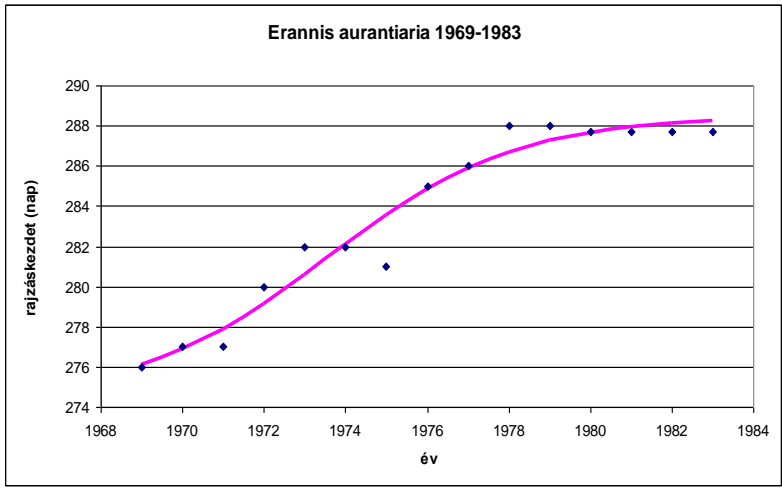

RAJZÁSHOSSZ

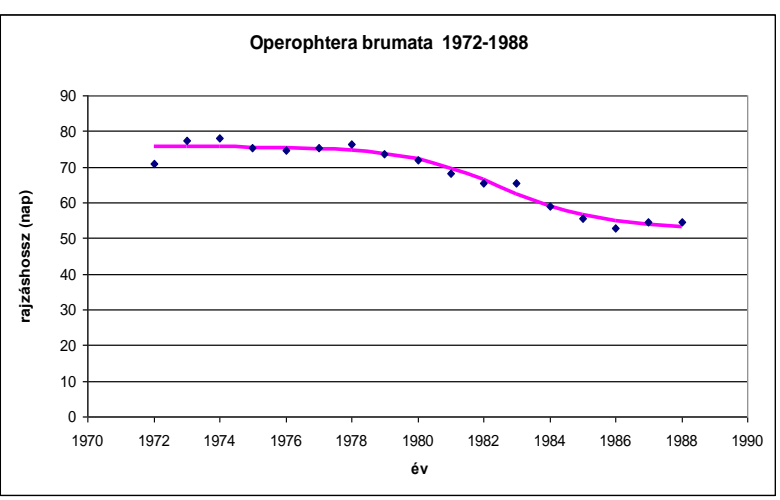

Erannis defoliaria 1972-1988

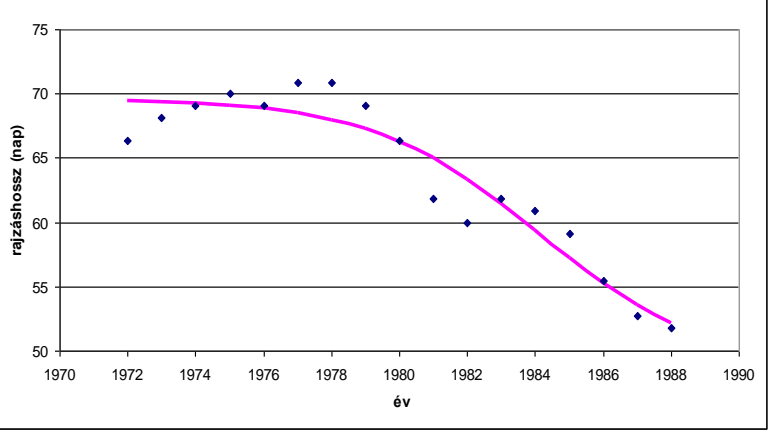

Colotois pennaria $1972-88$

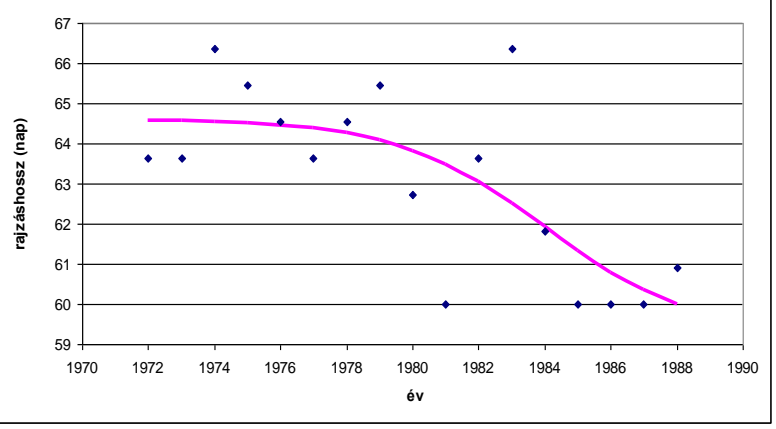

Erannis aurantiaria 1972-1988

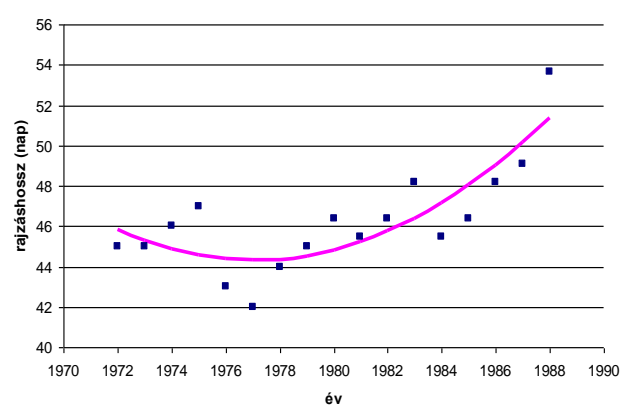

4. ábra. Négy vizsgált kártevö lepkefaj rajzáskezdetének (Julianus nap) és rajzáshosszának (nap) idösora és az illesztett logisztikus, illetve másodfokú modell (1972-1988), Erannis aurantiaria esetében a rajzáskezdetre 19691983 (forrás: a szerzö saját szerkesztése) 
11. táblázat. A logisztikus modell paramétereinek becslései és statisztikai értékelése a rajzáskezdet (Julianus nap) tekintetében a négy kártevö fajnál (1972-1988)

\begin{tabular}{|c|c|c|c|c|c|c|c|}
\hline Faj & & paraméter & $\mathbf{T}$ & SL & $\mathbf{F}$ & SL & $\mathbf{R}^{2}$ \\
\hline \multirow{4}{*}{ Operophtera brumata* } & $\mathrm{p} 1$ & 272,70 & 407,62 & $<0.001$ & \multirow{4}{*}{202135,1} & \multirow{4}{*}{$<0,001$} & \multirow{4}{*}{0,98} \\
\hline & p2 & 292,77 & 218,65 & $<0.001$ & & & \\
\hline & p3 & 0,56 & 5,07 & $<0.001$ & & & \\
\hline & $\mathrm{p} 4$ & 11,11 & 29,01 & $<0.001$ & & & \\
\hline \multirow{4}{*}{ Erannis defoliaria* } & p1 & 267,96 & 184,17 & $<0.001$ & \multirow{4}{*}{113509,1} & \multirow{4}{*}{$<0,001$} & \multirow{4}{*}{0,96} \\
\hline & p2 & 292,31 & 97,15 & $<0.001$ & & & \\
\hline & p3 & 0,39 & 3,45 & $<0.01$ & & & \\
\hline & $\mathrm{p} 4$ & 10,90 & 14,44 & $<0.001$ & & & \\
\hline \multirow{4}{*}{ Colotois pennaria* } & p1 & 259,88 & 215,13 & $<0.001$ & \multirow{4}{*}{373143} & \multirow{4}{*}{$<0,001$} & \multirow{4}{*}{0,93} \\
\hline & $\mathrm{p} 2$ & 268,39 & 342,34 & $<0.001$ & & & \\
\hline & p3 & 0,41 & 2,51 & $<0.05$ & & & \\
\hline & $\mathrm{p} 4$ & 7,85 & 8,61 & $<0.001$ & & & \\
\hline \multirow{4}{*}{ Erannis aurantiaria** } & $\mathrm{p} 1$ & 274,45 & 105,15 & $<0.001$ & \multirow{4}{*}{256614,3} & \multirow{4}{*}{$<0,001$} & \multirow{4}{*}{0,96} \\
\hline & $\mathrm{p} 2$ & 288,47 & 320,87 & $<0.001$ & & & \\
\hline & p3 & 0,44 & 2,75 & $<0.05$ & & & \\
\hline & $\mathrm{p} 4$ & 5,58 & 5,70 & $<0.001$ & & & \\
\hline
\end{tabular}

*1972-1988**1969-1983

12. táblázat. A logisztikus, illetve másodfokú modell paramétereinek becslései és statisztikai értékelése a rajzáshossz (nap) tekintetében a négy kártevö fajnál

\begin{tabular}{|c|c|c|c|c|c|c|c|}
\hline Faj & & Paraméter & $\mathrm{T}$ & SL & $\mathrm{F}$ & SL & $\mathrm{R}^{2}$ \\
\hline \multirow{4}{*}{ Operophtera brumata } & $\mathrm{p} 1$ & 75,59 & 84,08 & $<0.001$ & \multirow{4}{*}{4679,10} & \multirow{4}{*}{$<0.001$} & \multirow{4}{*}{0,96} \\
\hline & $\mathrm{p} 2$ & 52,79 & 27,42 & $<0.001$ & & & \\
\hline & p3 & 0,68 & 3,77 & $<0.01$ & & & \\
\hline & $\mathrm{p} 4$ & 11,57 & 25,87 & $<0.001$ & & & \\
\hline \multirow{4}{*}{ Erannis defoliaria } & $\mathrm{p} 1$ & 69,61 & 52,85 & $<0.001$ & \multirow{4}{*}{3922,37} & \multirow{4}{*}{$<0.001$} & \multirow{4}{*}{0,91} \\
\hline & $\mathrm{p} 2$ & 48,46 & 6,95 & $<0.001$ & & & \\
\hline & p3 & 0,40 & 2,08 & $<0.1$ & & & \\
\hline & $\mathrm{p} 4$ & 13,17 & 7,09 & $<0.001$ & & & \\
\hline \multirow{4}{*}{ Colotois pennaria } & $\mathrm{p} 1$ & 64,62 & 64,68 & $<0.001$ & \multirow{4}{*}{5444,78} & \multirow{4}{*}{$<0.001$} & \multirow{4}{*}{0,51} \\
\hline & $\mathrm{p} 2$ & 59,17 & 11,94 & $<0.001$ & & & \\
\hline & p3 & 0,44 & 0,70 & ns. & & & \\
\hline & $\mathrm{p} 4$ & 13,06 & 2,66 & $<0.05$ & & & \\
\hline \multirow{4}{*}{ Erannis aurantaria* } & $\mathrm{p} 1$ & 46,51 & 36,19 & $<0.001$ & \multirow{4}{*}{15,60} & \multirow{4}{*}{$<0.001$} & \multirow{4}{*}{0,69} \\
\hline & $\mathrm{p} 2$ & $-0,72$ & $-2,20$ & $<0.05$ & & & \\
\hline & p3 & 0,06 & 3,35 & $<0.01$ & & & \\
\hline & $\mathrm{p} 1$ & 46,51 & 36,19 & $<0.001$ & & & \\
\hline
\end{tabular}

*másodfokú modell

ns.: nem szignifikáns 


\subsubsection{Az Operophtera brumata (L.) fajra vonatkozó részletes eredmények és} azok értékelése

A 80-as évektől kezdődően markánsan kirajzolódik, hogy a rajzáskezdet egyre később indult meg, valamint ezzel egy időben a rajzáshossz, megrövidült. A 4. ábrákból kiolvasható hogy a rajzáskezdet egyre jobban kitolódott a 80-as évektől kezdődően, valamint ezzel egy időben a rajzáshossz, pontosabban a fénycsapdák által detektálható rajzás hossza is lecsökkent. A további vizsgálatok eredményei ennek a jelenségnek az időjárási tényezőkben rejlő lehetséges okaira igyekeznek rávilágítani.

Ennek érdekében mind a 17 évből kiemeltünk két-két intervallumot a lepkék lárva (51160. Julianus nap) és imágó (241-330. Julianus nap) alakjának megfelelően.

Az év 51-160. és a 240-330. Julianus napjai közötti intervallumokat dekádokra bontottuk, és a napi minimum, maximum és átlaghőmérsékleti adatokból képeztünk tíznapos átlagokat. Ugyanígy jártunk el a csapadék, valamint a sugárzás napi adataival is, így indikátor-adatbázist hoztunk létre. Ezt követően meghatároztuk a lepkék rajzáskezdetének időpontját és megvizsgáltuk az indikátorok között fennálló lineáris kapcsolat szorosságát.

13. táblázat A rajzáskezdetekkel szignifikáns összefüggöséget mutató indikátorok Pearson-féle korrelációs együttható (r) és szignifikancia értékei

\begin{tabular}{|c|c|c|c|c|}
\hline Indikátorok & Leírás & $\boldsymbol{r}$ & \multicolumn{2}{|c|}{ SL } \\
\hline TMIN5 & Az 51-60. Julianus nap minimumhőmérsékleteinek átlaga $\left({ }^{\circ} \mathrm{C}\right)$ & $-0,519$ & 0,033 & ** \\
\hline TMIN6 & A 61-70. Julianus nap minimumhőmérsékleteinek átlaga $\left({ }^{\circ} \mathrm{C}\right)$ & $-0,535$ & 0,027 & ** \\
\hline TMIN7 & A 71-80. Julianus nap minimumhőmérsékleteinek átlaga $\left({ }^{\circ} \mathrm{C}\right)$ & $-0,522$ & 0,032 & $* *$ \\
\hline TMIN9 & Az 91-100. Julianus nap minimumhőmérsékleteinek átlaga $\left({ }^{\circ} \mathrm{C}\right)$ & 0,469 & 0,057 & * \\
\hline TMIN29 & A 291-300. Julianus nap minimumhőmérsékleteinek átlaga $\left({ }^{\circ} \mathrm{C}\right)$ & 0,480 & 0,051 & $*$ \\
\hline TMIN31 & Az 311-320. Julianus nap minimumhőmérsékleteinek átlaga $\left({ }^{\circ} \mathrm{C}\right)$ & $-0,453$ & 0,068 & * \\
\hline TMAX5 & Az 51-60. Julianus nap maximumhőmérsékleteinek átlaga $\left({ }^{\circ} \mathrm{C}\right)$ & $-0,734$ & 0,001 & $* * *$ \\
\hline TMAX6 & A 61-70. Julianus nap maximumhőmérsékleteinek átlaga $\left({ }^{\circ} \mathrm{C}\right)$ & $-0,586$ & 0,013 & $* *$ \\
\hline TMAX7 & A 71-80. Julianus nap maximumhőmérsékleteinek átlaga $\left({ }^{\circ} \mathrm{C}\right)$ & $-0,639$ & 0,006 & $* * *$ \\
\hline TATL5 & Az 51-60. Julianus nap középhőmérsékleteinek átlaga $\left({ }^{\circ} \mathrm{C}\right)$ & $-0,620$ & 0,008 & $* * *$ \\
\hline TATL6 & A 61-70. Julianus nap középhőmérsékleteinek átlaga $\left({ }^{\circ} \mathrm{C}\right)$ & $-0,569$ & 0,017 & $* *$ \\
\hline TATL7 & A 71-80. Julianus nap középhőmérsékleteinek átlaga $\left({ }^{\circ} \mathrm{C}\right)$ & $-0,573$ & 0,016 & $* *$ \\
\hline TATL29 & A 291-300. Julianus nap középhőmérsékleteinek átlaga $\left({ }^{\circ} \mathrm{C}\right)$ & 0,462 & 0,062 & $*$ \\
\hline RAIN28 & A 281-290. Julianus nap csapadékmennyiségének átlaga (mm) & $-0,476$ & 0,053 & $*$ \\
\hline TMAX567 & Az 51-80. Julianus nap maximumhőmérsékleteinek átlaga $\left({ }^{\circ} \mathrm{C}\right)$ & $-0,760$ & 0,000 & $* * *$ \\
\hline TMIN567 & Az 51-80. Julianus nap minimumhőmérsékleteinek átlaga $\left({ }^{\circ} \mathrm{C}\right)$ & $-0,688$ & 0,002 & $* * *$ \\
\hline TATL567 & A 51-80. Julianus nap középhőmérsékleteinek átlaga $\left({ }^{\circ} \mathrm{C}\right)$ & $-0,716$ & 0,001 & $* * *$ \\
\hline
\end{tabular}

\footnotetext{
$* \mathrm{p}<0,1 * * \mathrm{p}<0,05 * * * \mathrm{p}<0,01$
} 
A rajzáskezdetek a napi időjárási adatokból kiszámolt dekádok átlagaiként meghatározott indikátorok közül 14-gyel (13. táblázat) mutattak szignifikáns korrelációt.

A lárvák aktivitási időszakában mért alacsony tavaszi hőmérséklet kisebb imágó populációkat és látszólag későbbi rajzáskezdetet indukál. Feltételeztük annak a lehetőségét is, hogy ezek az indikátorok nem külön-külön, hanem egymással összefüggésben hatnak, ezért e három dekád maximum-, minimum- és átlaghőmérséklet-indikátorainak az átlagát képeztük (TMAX567, TMIN567, TATL567-tel jelölve). Az összetett indikátorok is szignifikáns korrelációt mutatnak a rajzáskezdettel.

A 28. dekád csapadék-indikátora (RAIN28) közepes erősségű negatív irányú korrelációt mutat a rajzáskezdettel. Az ezt követő dekád minimum- és átlaghőmérséklet-indikátora (TMIN29, TATL29) már pozitív korrelációt mutat a rajzás kezdettel, mely a csapadékot követő hőmérsékletre utal. Elmondható, hogy a nagyobb mennyiségü októberi csapadék, valamint az azt követő hideg/fagyos időjárás jobban elősegíti a rajzás megindulását. A rajzás kezdetét az első fagyok utáni enyhébb időjárás segíti a leginkább, mivel a 31. dekád (november eleje) minimumhőmérsékletének indikátora szignifikáns negatív irányú korrelációjú a rajzáskezdettel.

Mivel kutatásunkat elsősorban a klímaváltozás jövőben várható hatásainak becslésére kívántuk használni, ezért a továbbiakban megkülönböztettünk csapadék-indikátort tartalmazó, illetve azt nem tartalmazó lineáris modelleket. A klímamodellek jövőbeli prognózisainak bizonytalanságai miatt tettük ezt, hiszen a bizonytalanság a csapadékok napi adatait tekintve a legnagyobbak.

A fenti indikátorokat (beleértve a tavaszi dekádokra képzett összetett indikátorokat is) tehát magyarázó változónak tekintve stepwise módszerrel képeztük az

$$
Y=p_{0}+\sum_{i=1}^{n} p_{i} X_{i}+e
$$

alakú lineáris regressziós modelleket (14. táblázat). A klímamodellek legkisebb megbízhatósággal becsülik a csapadék várható változását. A vizsgálatunk során ezért készítettünk csapadék nélküli és csapadék indikátorral is rendelkező modelleket. A csapadék és hőmérséklet indikátorokat tartalmazó modellekbe több hőmérsékleti indikátor is beépíthető lett volna. Mivel a modellbe kevés indikátort tudunk beletenni, ezért összevonással így többnek a hatását be tudtunk rakni, mint például az 5., 6., 7., dekádok indikátoraiból összetett indikátorokat alkottunk TATL567 vagy TMAX567. A 3. és a 4. modell közötti különbség abban áll, hogy ugyan mind a 2 modellben szerepel a csapadék indikátor, de ha beletesszük még az őszi hőmérséklet-indikátort is, akkor jobb modellt kapunk. 
14. táblázat. A többváltozós lineáris regressziós modell paraméterei és statisztikai értékelése

\begin{tabular}{|c|c|c|c|c|c|c|c|}
\hline & & araméter & $\mathbf{T}$ & T_SL & $\mathbf{F}$ & F_SL & $\mathbf{R}^{2}$ \\
\hline \multicolumn{8}{|c|}{ 1. modell (csapadékindikátor nélkül, összetett tavaszi hőmérséklet indikátorral) } \\
\hline \multirow{2}{*}{$\begin{array}{l}\text { CONST, } \\
\text { TMAX567 }\end{array}$} & p0 & 296,44 & 78,57 & $<0,001$ & \multirow{2}{*}{20,57} & \multirow{2}{*}{$<0,001$} & \multirow{2}{*}{0,578} \\
\hline & $\mathrm{p} 1$ & $-0,634$ & $-4,54$ & $<0,001$ & & & \\
\hline \multicolumn{8}{|c|}{ 2. modell (csapadékindikátor nélkül, tavaszi és őszi hőmérséklet indikátorral) } \\
\hline \multirow{3}{*}{$\begin{array}{l}\text { CONST, } \\
\text { TMAX5, } \\
\text { TMIN29 }\end{array}$} & p0 & 280,99 & 60,22 & $<0,001$ & \multirow{3}{*}{14,92} & \multirow{3}{*}{$<0,001$} & \multirow{3}{*}{0,681} \\
\hline & p1 & $-1,72$ & $-4,44$ & $<0,01$ & & & \\
\hline & $\mathrm{p} 2$ & 1,44 & 2,49 & $<0,05$ & & & \\
\hline \multicolumn{8}{|c|}{ 3. modell (őszi csapadékindikátorral, összetett tavaszi hőmérséklet indikátorral) } \\
\hline \multirow{3}{*}{\begin{tabular}{|l|} 
CONST, \\
TATL567, \\
RAIN28
\end{tabular}} & p0 & 292,74 & 112,874 & $<0,001$ & \multirow{3}{*}{14,3} & \multirow{3}{*}{$<0,001$} & \multirow{3}{*}{0,671} \\
\hline & p1 & $-0,67$ & $-4,35$ & $<0,05$ & & & \\
\hline & $\mathrm{p} 2$ & $-1,85$ & $-2,60$ & $<0,05$ & & & \\
\hline \multicolumn{8}{|c|}{ 4. modell (őszi csapadék- és hőmérséklet-indikátorral, összetett tavaszi hőmérséklet indikátorral) } \\
\hline \multirow{4}{*}{$\begin{array}{l}\text { CONST, } \\
\text { TMAX567, } \\
\text { RAIN28, } \\
\text { TATL29 }\end{array}$} & $\mathrm{p} 0$ & 285,33 & 43,42 & $<0,001$ & \multirow{4}{*}{15,16} & \multirow{4}{*}{$<0,001$} & \multirow{4}{*}{0,778} \\
\hline & $\mathrm{p} 1$ & $-0,54$ & $-4,79$ & $<0,001$ & & & \\
\hline & $\mathrm{p} 2$ & $-1,47$ & $-2,39$ & $<0,05$ & & & \\
\hline & p3 & 1,16 & 2,17 & $<0,05$ & & & \\
\hline
\end{tabular}

Az indikátorok nem függetlenek egymástól, ezért indokoltnak láttuk egy fökomponens regressziós modell előállítását is. A változók csökkentése érdekében elvégzett elemzés eredményeképpen három faktorba soroltuk be az indikátorokat (FAKT1, FAKT2, FAKT3), a komponensek az indikátor-változók által hordozott információ 82,2 \%-át magyarázza.

A fökomponens regressziós modell esetén az alábbi indikátorokat vettük figyelembe:

FAKT1 esetében a kora tavaszi, tél végi hőmérsékleti indikátorok, mint TATL567, TMAX567, TMIN567, TMIN9 - azaz a lárvák kikelését megelőző egy hónap hőmérsékleti indikátorait, (február 10. - március 10. középhőmérsékletek, maximumhőmérsékletek, minimumhőmérsékletek és a március végi minimumhőmérsékletek átlagát).

FAKT2 esetében az őszi hőmérsékleti indikátorokat, mint TATL29, TMIN29 - október első felének minimum- és átlaghőmérséklete.

FAKT3 esetében az őszi csapadék és minimumhőmérséklet indikátorokat, mint a RAIN28, TMIN31 - október eleji csapadék és november eleji minimumhőmérsékletek indikátorait.

Ezután az új változókkal is végeztünk többváltozós lineáris regressziót (15. táblázat).

15. táblázat. A fókomponens regressziós modell paraméterei és statisztikai értékelése:

\begin{tabular}{|l|c|c|c|c|c|c|c|}
\hline & & paraméter & T & T_SL & F & F_SL & $R^{2}$ \\
\hline CONST, & $\mathrm{p} 0$ & 280,29 & 333,453 & $<0,001$ & & & \\
\cline { 2 - 5 } FAKT1, & $\mathrm{p} 1$ & $-5,14$ & $-5,936$ & $<0,001$ & & & \\
FAKT2, & $\mathrm{p} 2$ & 2,36 & 2,727 & $<0,05$ & & $<0,001$ & 0,833 \\
\cline { 2 - 5 } & $\mathrm{p} 3$ & $-4,10$ & $-4,732$ & $<0,001$ & & & \\
\hline
\end{tabular}


Mivel a főkomponens-regresszió modellje bizonyult a legsikeresebbnek, ezért a jövőre vonatkozó becsléseinkhez is ezt vettük alapul. A fökomponens regresszióban kapott faktorok értékeit a RegCM3.1 regionális klímamodell 2021-2050-es időszeletre prognosztizált eredményeivel is kiszámoltuk, és becsültük a várható rajzáskezdeteket, illetve eloszlásának várható változását (5. ábra). Ezek különbsége adja a várható eloszlás-változást, ami alapján a 2021-2050-es időszakra vonatkozó becsült rajzáskezdet-eloszlás előállítható.

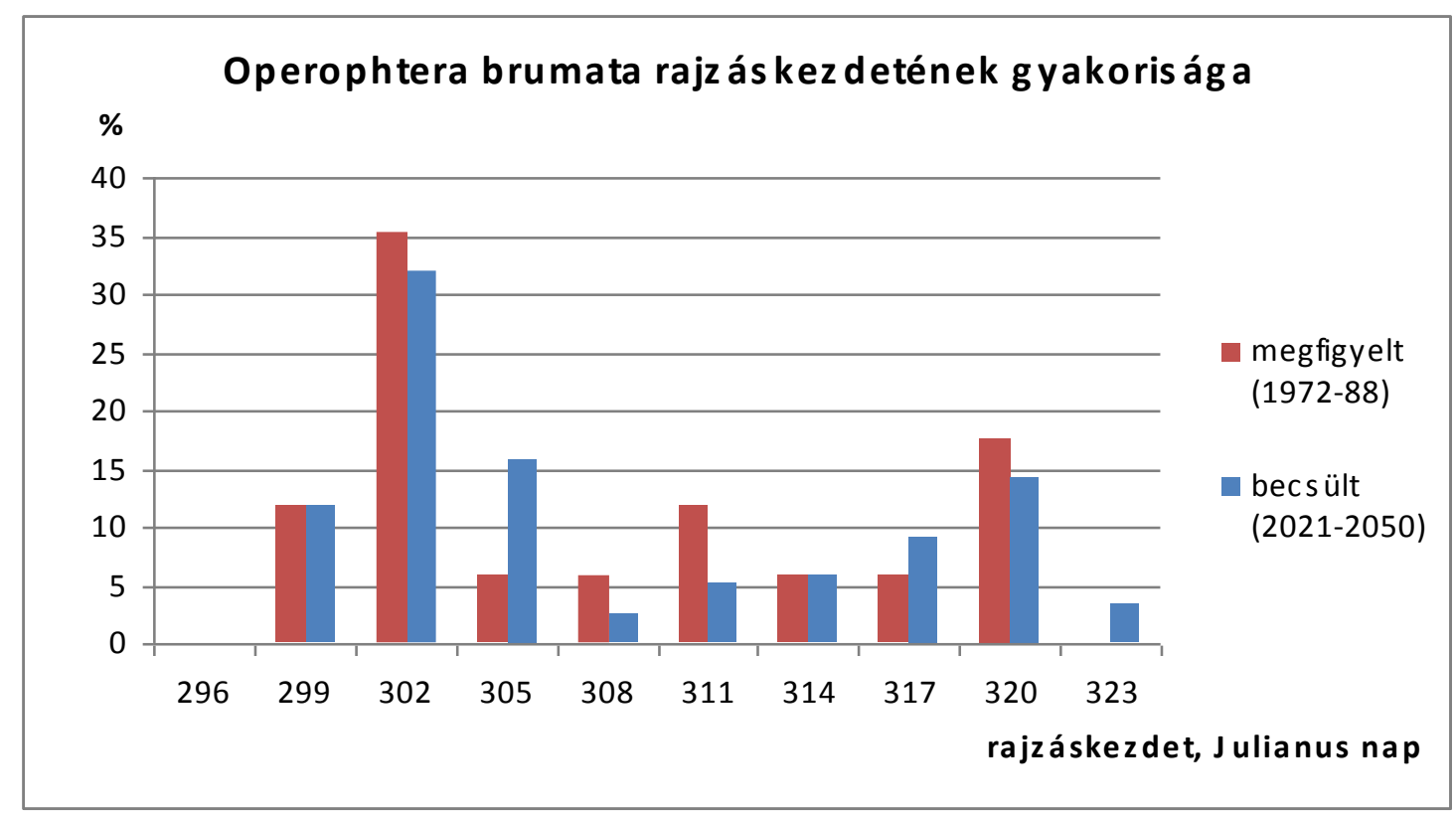

5. ábra A rajzáskezdetek megfigyelt és a RegCM 3.1 modell alapján 2021-2050-re becsült gyakorisága (forrás: a szerzö saját szerkesztése)

Vizsgálat eredménye szerint a megfigyelt 40 év alatt a rajzáskezdetek 299. és 320. Julianus nap közé estek, míg a 2021-2050-es időintervallumra becsült 30 évnyi rajzáskezdetek a 296. és a 326. nap közé estek. A vizsgált két időszak közötti eltérés 9 nap, tehát a legkorábbi és legkésőbbi rajzáskezdetek a vizsgált jövőben 9 nappal térnek el a megfigyelttöl. Az eredményül kapott eloszlásokat megfigyelve láthatjuk, hogy a megfigyelt rajzáskezdetek eloszlása is kétcsúcsú, ám a 2021-2050-es időszakra még több késői rajzáskezdet várható. A rajzáskezdetek várható terjedelme 9 nappal nő a megfigyelthez képest. Az extrém késői (november közepi) rajzáskezdetek gyakorisága várhatóan növekedni fog, ami valószínűleg igen rövid rajzáshosszal párosul majd. 


\subsection{Populációdinamikai modellek}

\subsubsection{Differenciaegyenleten \\ és \\ indikátoranalízisen \\ alapuló populációdinamikai modellek}

\section{Operophtera brumata}

A klímaindikátorok közül 26 áll szignifikáns kapcsolatban az egyedszám alakulással. A Bayes-féle Akaike információs kritérium egyetlen indikátor bevonásakor volt minimális $\left(\mathrm{AIC} \mathrm{B}_{\mathrm{B}}=\right.$ -6,166), ezt tekintettük a legjobb modellnek. Ez az indikátor nem más, mint az ETMAXX8, az előző év 8. dekádjának (márc. 12.- márc. 21.) napi maximumhőmérsékletének maximuma 0,0377 együtthatóval. Az indikátornak az egyedszámmal vett korrelációs értéke szignifikáns $(R=0,37$; $\mathrm{p}<0,05)$

A 6. ábra mutatja a megfigyelt, valamint az alap- és a bővített modell által becsült egyedszámokat. Az alapmodell által becsült egyedszám korrelációja a megfigyelt értékekkel szignifikáns $\left(R_{a}=0,86 ; \mathrm{p}<0,001\right)$, a bővített modell becslésének korrelációja magasabb, szintén szignifikáns $\left(R_{b}=0,91 ; \mathrm{p}<0,001\right)$. A klímaindikátorokkal bővített modell eltartó kapacitása és sebességi tényezője is alacsonyabb az alapmodell értékeihez viszonyítva, viszont a maximális szaporodási ráta értéke közel az ötszöröse. A modell becslésének hibatagjának értéke alacsonyabb, ami pontosabb modellt jelent (16. táblázat).

16. táblázat. Az Operophtera brumata fajra vonatkozó alapmodell és a klímaindikátorral bövített modell föbb paraméterei (1962-2000)

\begin{tabular}{|l|c|c|}
\hline & alapmodell & bövített modell \\
\hline Eltartó kapacitás $(K)$ & 6,4836 & 4,3848 \\
\hline sebességi tényezö $(\theta)$ & 0,0008 & 0,0003 \\
\hline maximális szaporodási ráta $\left(R_{\max }\right)$ & 281,5237 & 1448,5426 \\
\hline AIC ${ }_{\mathrm{B}}$ & $-0,6492$ & $-6,1667$ \\
\hline korrelációs együttható $(R)$ & 0,8602 & 0,9097 \\
\hline a becslés hibája $(R M S E)$ & 0,8286 & 0,6747 \\
\hline
\end{tabular}

A modell meglehetősen jól illeszkedik a megfigyelésekhez, de némely gradációs időszakban alulbecsüli az egyedszámot. 


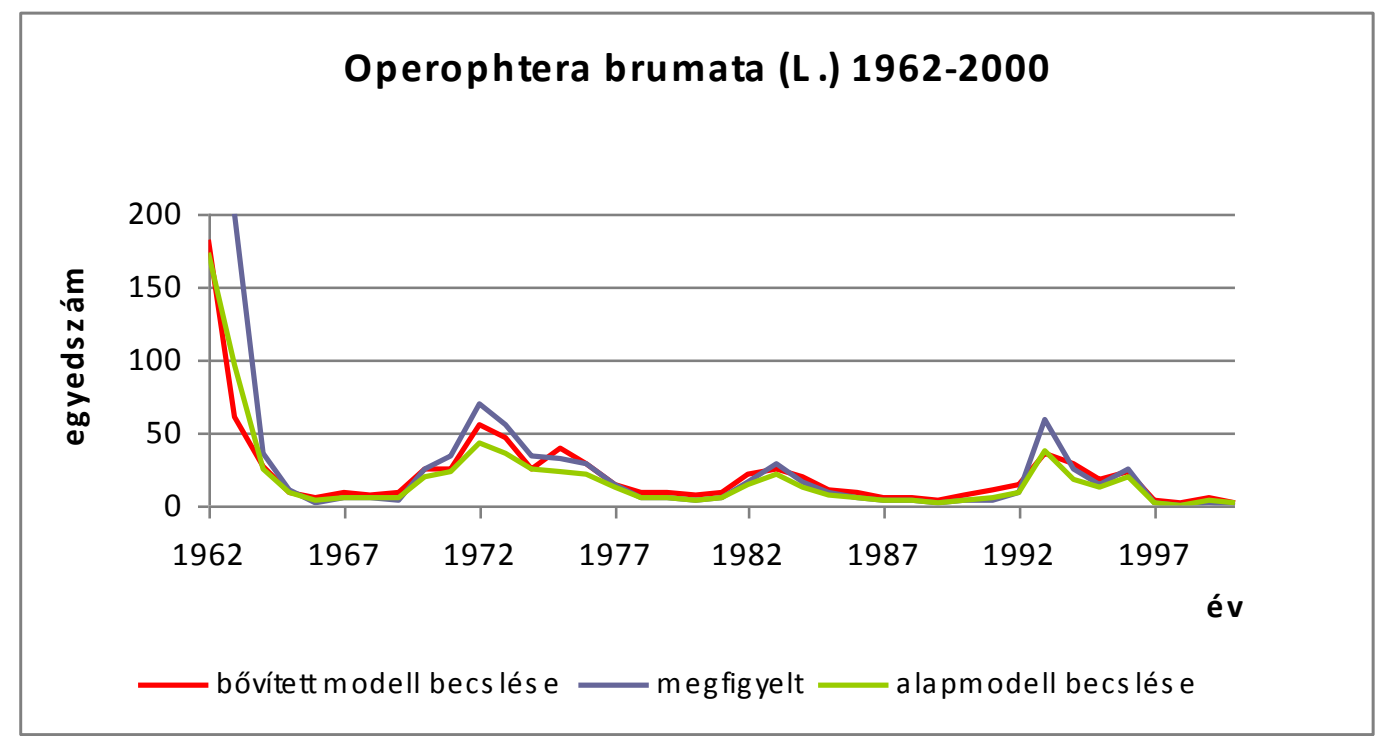

6. ábra Az Operophtera brumata megfigyelt adataiból számított egyedszámok, valamint az alapmodell és a klímaindikátorral bövitett modell becslése (forrás: a szerzö saját szerkesztése)

\section{$\underline{\text { Erannis defoliaria }}$}

Az E. defoliaria esetében 30 indikátort válogattunk le, amelyek szignifikáns összefüggést mutatnak az egyedszámmal, illetve annak változásával.

A Bayes-féle Akaike információs kritérium minimumát az alapmodellünk egyetlen indikátorral, a vizsgált év 10. hónapjának napi minimumhőmérsékleti értékeinek a minimumával való bővítésével értük el $\left(\mathrm{AIC}_{\mathrm{B}}=-11,78\right)$. A MTMINN10 klímaindikátorral $(r=-0,35 ; \mathrm{p}<0,05)$ bővített modell volt a legjobb, melynek együtthatója -0,112.

A 7. ábra mutatja a megfigyelt, valamint a becsült alap- és a bővített modell által becsült egyedszámokat. Az alapmodell által becsült egyedszám korrelációja a megfigyelt értékekkel szignifikáns $\left(R_{a}=0,920 ; \mathrm{p}<0,001\right)$, a bővített modell becslésének korrelációja valamivel magasabb, szintén szignifikáns $\left(R_{b}=0,930 ; \mathrm{p}<0,001\right)$. A klímaindikátorokkal bővített modell eltartó kapacitása magasabb az alapmodell értékeihez viszonyítva, a sebességi tényezők változása oly csekély, hogy az elhanyagolható, viszont a maximális szaporodási ráta értéke alacsonyabb az alapmodell értékénél. A modell becslésének hibatagjának értéke alacsonyabb, ami pontosabb modellt jelent (17. táblázat).

17. táblázat. Az Erannis defoliaria fajra vonatkozó alapmodell és a klímaindikátorral bövített modell föbb paraméterei (1962-2000)

\begin{tabular}{|l|c|c|}
\hline & alapmodell & bővített modell \\
\hline Eltartó kapacitás $(K)$ & 5,1765 & 7,2900 \\
\hline sebességi tényezö $(\theta)$ & 0,0006 & 0,0006 \\
\hline Maximális szaporodási ráta $\left(R_{\max }\right)$ & 673,2240 & 611,8800 \\
\hline AIC & $-11,6050$ & $-11,7770$ \\
\hline korrelációs együttható $(R)$ & 0,9195 & 0,9300 \\
\hline a becslés hibája $(R M S E)$ & 0,6256 & 0,5843 \\
\hline
\end{tabular}


A modell meglehetősen jó becslést ad, az extrém magas gradációt azonban nagy mértékben alulbecsüli.

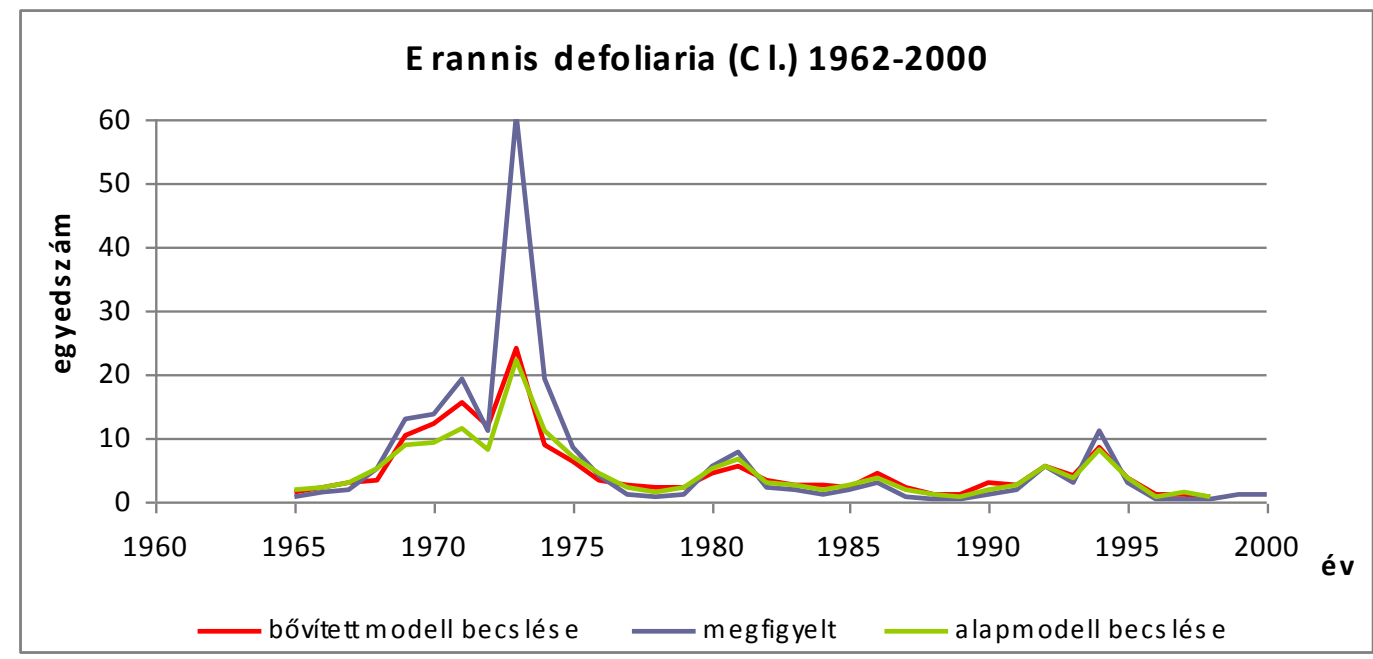

7. ábra Az Erannis defoliaria megfigyelt adataiból számított egyedszámok, valamint az alapmodell és a klímaindikátorral bövitett modell becslése(forrás: a szerzö saját szerkesztése)

\section{Colotois pennaria}

A C. pennaria esetében 11 indikátort válogattunk le, amelyek szignifikáns összefüggést mutattak az egyedszámmal, illetve annak változásával. A modell bővítéséhez ebből hármat használtunk fel az Akaike-féle információs kritérium minimumának $\left(\mathrm{AIC}_{\mathrm{B}}=0,51\right)$ eléréséhez. Ezeket az indikátorokat a 18. táblázat tartalmazza.

18. táblázat A Colotois pennaria esetében leválogatott indikátorok közül a bővített modellbe beválogatott indikátorok Pearson-féle korrelációs együtthatói $(r)$ és szignifikancia értékei

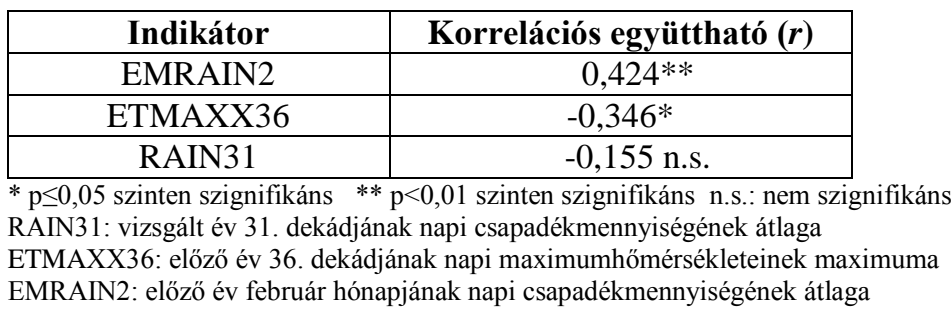

$\mathrm{Az}$ alapmodellünket az előző év februári napi csapadékmennyiségének átlagával (EMRAIN2), az előző év 36. dekádjának napi maximumhőmérsékleteinek maximumával (ETMAXX36) és a vizsgált év 31. dekádjának napi csapadékmennyiségének átlagával (RAIN31) bővítettük. Az együtthatókat a 19. táblázat mutatja.

19. táblázat $\mathrm{A}$ legalacsonyabb $\mathrm{AIC}_{\mathrm{B}}$ értékkel definiált legjobb modell együtthatói

\begin{tabular}{|c|c|c|}
\hline EMRAIN2 & ETMAXX36 & RAIN31 \\
\hline 0,146 & $-0,176$ & $-0,292$ \\
\hline
\end{tabular}


A 8. ábra mutatja a megfigyelt, valamint az alap- és a bővített modell által becsült egyedszámokat. Az alapmodell és a bővített modell korrelációs együtthatója is szignifikáns $\left(R_{a}=\right.$ 0,$451 ; \mathrm{p}<0,001 ;$ illetve $\left.R_{b}=0,87 ; \mathrm{p}<0,001\right)$, a bővített modell jóval nagyobb korrelációs együtthatóval közelíti a megfigyelt értékeket. A klímaindikátorokkal bővített modell eltartó kapacitás értéke jelentősen magasabb, a sebességi tényezője alacsonyabb az alapmodell értékeihez viszonyítva, viszont a maximális szaporodási ráta értéke majdnem a fele. A modell becslésének hibatagjának értéke alacsonyabb, ami pontosabb modellt jelent (20. táblázat).

20. táblázat. A Colotois pennaria fajra vonatkozó alapmodell és a klímaindikátorral bövített modell föbb paraméterei (1962-2000)

\begin{tabular}{|l|c|c|}
\hline & alapmodell & bővített modell \\
\hline eltartó kapacitás $(K)$ & 4,3045 & 703,7000 \\
\hline sebességi tényezö $(\theta)$ & 0,0007 & 0,0004 \\
\hline Maximális szaporodási ráta $\left(R_{\max }\right)$ & 723,3058 & 385,0600 \\
\hline AIC $\mathrm{B}$ & 15,7554 & 0,5140 \\
\hline korrelációs együttható $(R)$ & 0,4514 & 0,8700 \\
\hline a becslés hibája $(R M S E)$ & 1,2618 & 0,6964 \\
\hline
\end{tabular}

Az optimalizálás végrehajtása során a kiugró értékek éveit elhagyva végeztünk újabb modellezést az 1972-2000 közötti évekre. Ez esetben a szignifikáns összefüggést mutató RAIN31-es indikátort, azaz a vizsgált év 31. dekádjának napi csapadékmennyiségének átlagát vontuk be a modellbe $(R=0,492 ; \mathrm{p}<0,001)$. A Bayes-féle Akaike információs kritérium szerint $\left(\mathrm{AIC}_{\mathrm{B}}=-3,48\right)$ a RAIN31 klímaindikátorral bővített modell volt a legjobb, melynek RAIN31 együtthatója 0,093 .

A 9. ábra mutatja a megfigyelt, valamint az alap- és a bővített modell által becsült egyedszámokat. Az alapmodell és a bővített modell korrelációs együtthatója is szignifikáns $\left(R_{a}=0,478 ; \mathrm{p}<0,001 ;\right.$ illetve $\left.R_{b}=0,514 ; \mathrm{p}<0,001\right)$, a bővített korrelációja magasabb. A klímaindikátorokkal bővített modell eltartó kapacitása alacsonyabb az alapmodell értékeihez viszonyítva, a sebességi tényező változása oly csekély, hogy az elhanyagolható, és a maximális szaporodási ráta értéke sem változott számottevően. A modell becslésének hibatagjának értéke valamivel alacsonyabb, ami pontosabb modellt jelent (21. táblázat).

21. táblázat. A Colotois pennaria fajra vonatkozó alapmodell és a klímaindikátorral bövített modell föbb paraméterei (1972-2000)

\begin{tabular}{|l|c|c|}
\hline & alapmodell & bővített modell \\
\hline eltartó kapacitás $(K)$ & 2,9811 & 2,4053 \\
\hline sebességi tényező $(\theta)$ & 0,0007 & 0,0007 \\
\hline Maximális szaporodási ráta $\left(R_{\max }\right)$ & 811,1516 & 812,0976 \\
\hline AIC $_{\mathrm{B}}$ & $-5,5030$ & $-3,4823$ \\
\hline korrelációs együttható $(R)$ & 0,4780 & 0,5139 \\
\hline a becslés hibája $(R M S E)$ & 0,6507 & 0,6355 \\
\hline
\end{tabular}


Az alapmodellnél alig volt jobb bővített modell, illetve ha az indikátorok az 1971-es nagyon kiugró értéket jól magyarázták, akkor azzal együtt a többi évben a becslések torzultak. Amikor a modellt csak 1972-től vizsgáltuk, akkor az alapmodell lett a legjobb.
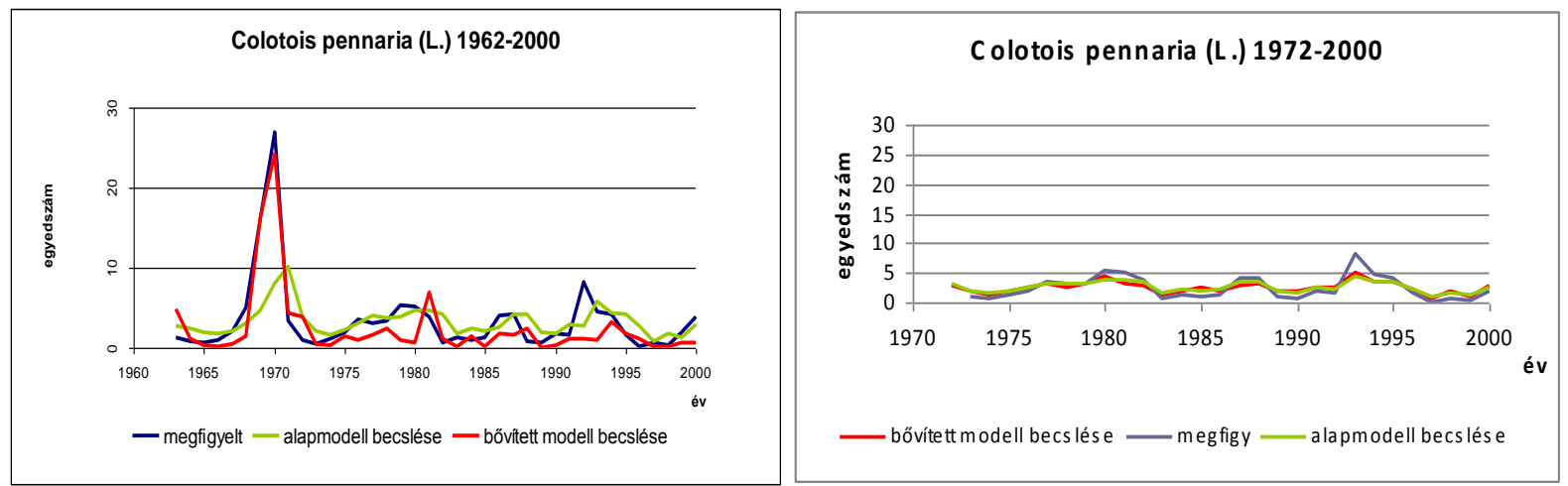

8-9. ábra A Colotois pennaria megfigyelt adataiból számított egyedszámok, valamint az alapmodell és a klimaindikátorral bővitett modell becslése (forrás: a szerző saját szerkesztése)

1971-ben nemcsak a lepkék egyedszáma mutat nagyon kiugró értéket, hanem az indikátorok közül a RAIN31 is (10-11. ábra), mely arra enged következtetni, hogy a 31. dekád csapadék paramétere jelentősen befolyásolta az adott évi gradációt.
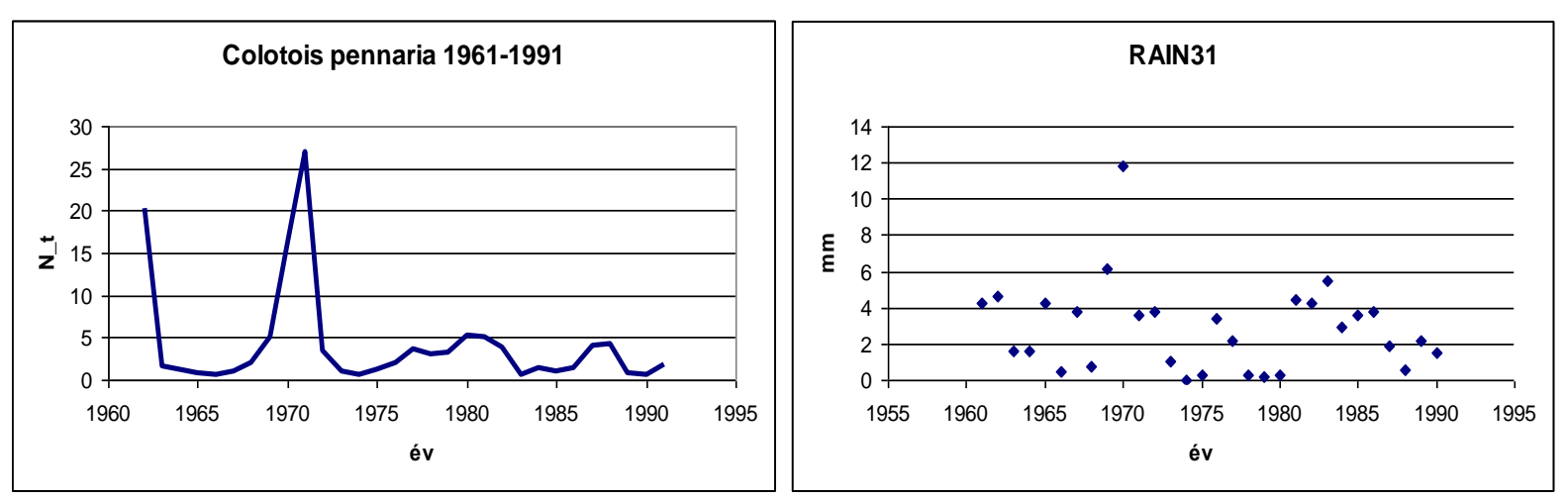

10-11. ábra A Colotois pennaria egyedszám-változása, illetve az október végi - november eleji csapadékmennyiség (mm) 1961 és 1991 között (forrás: a szerzö saját szerkesztése)

\section{Erannis aurantiaria}

Az E. aurantiaria vizsgálatánál 15 indikátor állt szignifikáns összefüggésben az egyedszámmal, illetve annak változásával. A Bayes-féle Akaike információs kritérium egyetlen paraméter, az MRAIN11, azaz a vizsgált év novemberi napi csapadékmennyiségének átlagának 0,356 együtthatóval való bevonásával volt minimális $\left(\mathrm{AIC}_{\mathrm{B}}=-7,28\right)$. A bevont indikátor Pearsonféle korrelációs együtthatója $-0,365,(\mathrm{p}<0,001)$.

A 12. ábra mutatja a megfigyelt, valamint az alap- és a bővített modell által becsült egyedszámokat. Az alapmodell korrelációs együtthatója nem szignifikáns $(\mathrm{p}>0,05)$, de a bővített modellé már igen $\left(R_{b}=0,451 ; \mathrm{p}<0,01\right)$. A megfigyelt időintervallumban e faj egyedszámaira vonatkozó becslések bizonytalanok, a kiugró értékeket (pl. 1983-ban, 1984-ben, 1994-ben) jelentősen alulbecsülték a modellek. A klímaindikátorokkal bővített modell eltartó 
kapacitása és a maximális szaporodási ráta értéke magasabb, a sebességi tényezője alacsonyabb az alapmodell értékeihez viszonyítva. A modell becslésének hibatagjának értéke is alacsonyabb, ami pontosabb modellt jelent (22. táblázat).

22. táblázat. Az Erannis aurantiaria fajra vonatkozó alapmodell és a klímaindikátorral bövített modell föbb paraméterei (1966-2000)

\begin{tabular}{|l|c|c|}
\hline & alapmodell & bővített modell \\
\hline eltartó kapacitás $(K)$ & 2,4852 & 5,9699 \\
\hline sebességi tényezö $(\theta)$ & 0,0011 & 0,0007 \\
\hline Maximális szaporodási ráta $\left(R_{\max }\right)$ & 762,3978 & 954,0656 \\
\hline AIC ${ }_{\mathrm{B}}$ & $-6,5561$ & $-7,2839$ \\
\hline korrelációs együttható $(R)$ & 0,2126 & 0,4514 \\
\hline a becslés hibája $(R M S E)$ & 0,6910 & 0,6310 \\
\hline
\end{tabular}

Ha a modellezést csak 1994-ig végezzük, azaz a 1965-93-ig tartó intervallumra, akkor egy másik indikátort (RAIN31) találtunk, amellyel az alapmodellt becsülve kissé jobb modellt kapunk. Az alapmodellt a vizsgált év 31. dekádjának napi csapadékmennyiségének átlagával, $-0,293$ együtthatóval bővítettük $\left(\mathrm{AIC}_{\mathrm{B}}=-12,94\right)$. Az alapmodell korrelációs együtthatója nem szignifikáns, és bár a bővített modell korrelációja már szignifikáns, $\left(R_{b}=0,660 ; \mathrm{p}<0,001\right)$, a megfigyelt időintervallumon az egyedszámok becslése itt is sok esetben pontatlan (13. ábra). A klímaindikátorokkal bővített modell eltartó kapacitása és sebességi tényezője is magasabb az alapmodell értékeihez viszonyítva, viszont a maximális szaporodási ráta értéke alacsonyabb. A modell becslésének hibatagjának értéke alacsonyabb, ami pontosabb modellt jelent (23. táblázat).

23. táblázat. A Erannis aurantiaria fajra vonatkozó alapmodell és a klímaindikátorral bővített modell föbb paraméterei (1966-1993)

\begin{tabular}{|l|c|c|}
\hline & alapmodell & Bővített modell \\
\hline eltartó kapacitás $(K)$ & 2,4242 & 3,8612 \\
\hline sebességi tényező $(\theta)$ & 0,0011 & 0,0016 \\
\hline Maximális szaporodási ráta $\left(R_{\max }\right)$ & 697,7027 & 379,7749 \\
\hline AIC $\mathrm{B}$ & $-8,7955$ & $-12,9404$ \\
\hline korrelációs együttható $(R)$ & 0,2787 & 0,6602 \\
\hline a becslés hibája $(R M S E)$ & 0,5689 & 0,4449 \\
\hline
\end{tabular}
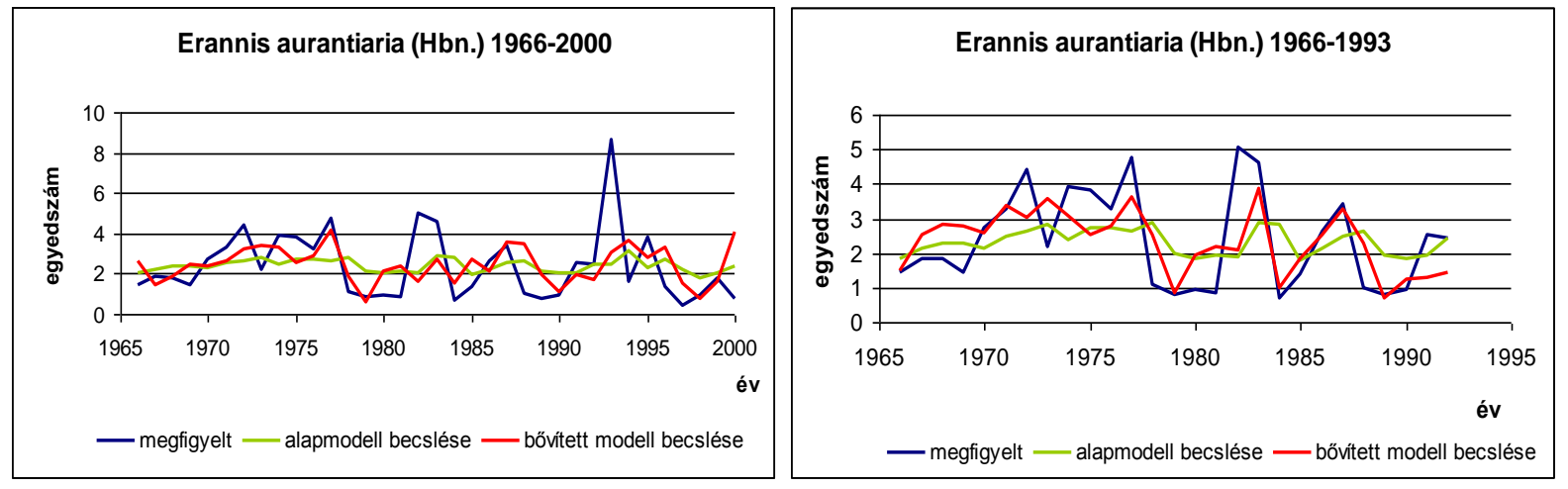

12-13. ábra Az Erannis aurantiaria megfigyelt adataiból számított egyedszámok, valamint az alapmodell és a klímaindikátorral bövitett modell becslése 1966-2000 valamint 1966 és 1993 között

(forrás: a szerzö saját szerkesztése) 


\section{$\underline{\text { Idaea dimidiata }}$}

Az I. dimidiata esetében 18 indikátort válogattunk le, amelyek a szignifikánsak az egyedszámmal, illetve annak változásával, és ezek közül három (24. táblázat) került bele a legjobb bővített modellbe.

24. táblázat Az Idaea dimidiata esetében leválogatott indikátorok közül a bővített modellbe beválogatott indikátorok Pearson-féle korrelációs együtthatói (R) és szignifikancia értékei

\begin{tabular}{|c|c|}
\hline Indikátor & Korrelációs együttható (R) \\
\hline RAIN9 & $0,367 *$ \\
\hline ETMIN18 & $-0,345^{*}$ \\
\hline ETMINN1 & $-0,340^{*}$ \\
\hline
\end{tabular}

Az alapmodellünket a vizsgált év 9. dekádjának napi csapadékmennyiségének átlagával, az előző év 18. dekádjának napi minimumhőmérsékleteinek átlagával és az előző év 1. dekádjának napi minimumhőmérsékleti értékeinek a minimumával bővítettük. A Bayes-féle Akaike-féle információs kritérium szerint $\left(\mathrm{AIC}_{\mathrm{B}}=-25,32\right)$ a már fent nevezett három klímaindikátorral rendelkező modell volt a legjobb, a modellben szereplő együtthatók: 0,114 (RAIN9), -0,01 (ETMIN18), valamint -0,050 (ETMINN1). A 14. ábra mutatja a megfigyelt, valamint az alap- és a bővített modell által becsült egyedszámokat. Az alapmodell és a bővített modell korrelációs együtthatója is szignifikáns $\left(R_{a}=0,767 ; \mathrm{p}<0,001 ;\right.$ illetve $R_{b}=0,89$; $\mathrm{p}<0,001)$. A klímaindikátorokkal bővített modell eltartó kapacitása és sebességi tényezője is jóval alacsonyabb az alapmodell értékeihez viszonyítva, viszont a maximális szaporodási ráta értéke közel a tízszerese. A modell becslésének hibatagjának értéke alacsonyabb, ami pontosabb modellt jelent (25. táblázat).

25. táblázat. Az Idaea dimidiata fajra vonatkozó alapmodell és a klímaindikátorral bővitett modell föbb paraméterei (1962-2000)

\begin{tabular}{|l|c|c|}
\hline & alapmodell & Bővített modell \\
\hline eltartó kapacitás $(K)$ & 1076,3944 & 253,5671 \\
\hline sebességi tényező $(\theta)$ & 0,0008 & 0,0001 \\
\hline Maximális szaporodási ráta $\left(R_{\max }\right)$ & 350,9609 & 3369,1510 \\
\hline AIC $\mathrm{B}$ & $-20,5769$ & $-25,3210$ \\
\hline korrelációs együttható $(R)$ & 0,7666 & 0,8859 \\
\hline a becslés hibája $(R M S E)$ & 0,4971 & 0,3591 \\
\hline
\end{tabular}

A három klímaindikátorral bővített modellben a megfigyelt időintervallumban a becslések jól illeszkednek a megfigyelt értékekre. 


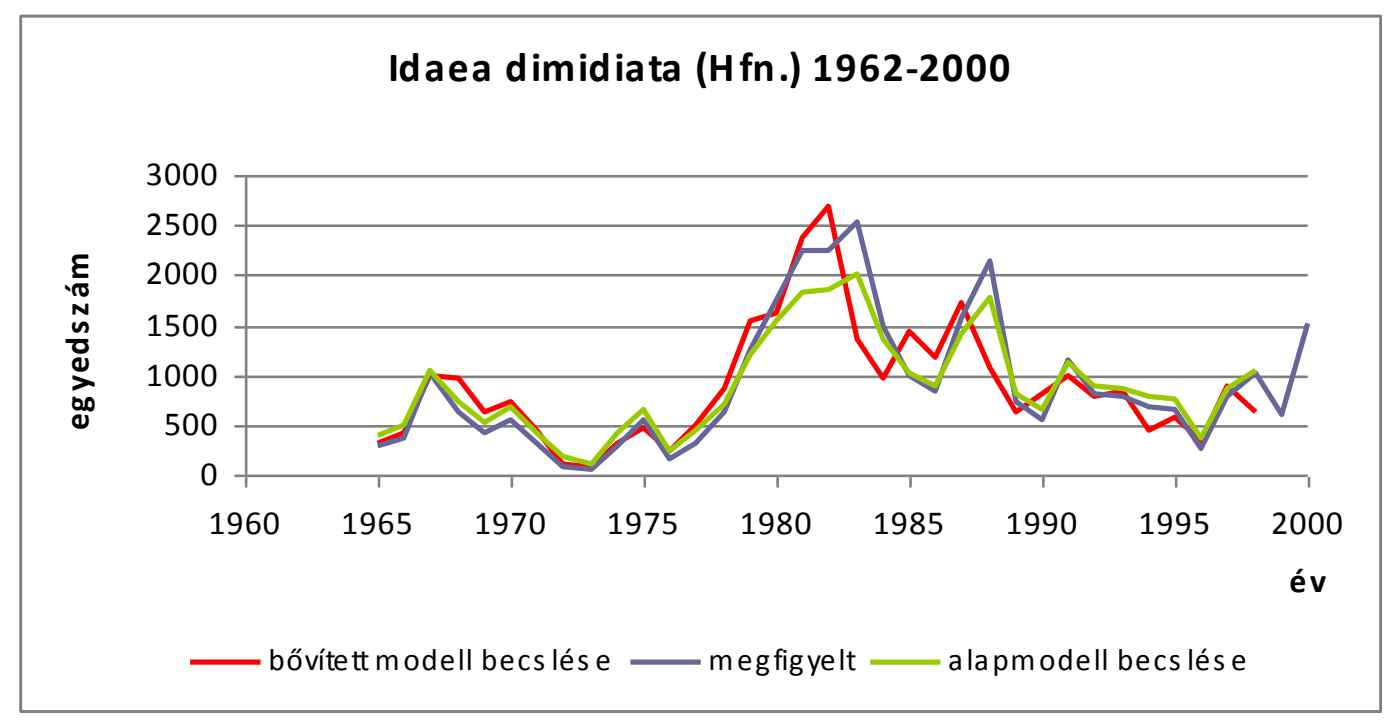

14. ábra Az Idaea dimidiata megfigyelt adataiból számitott egyedszámok, valamint az alapmodell és a klímaindikátorral bővített modell becslése (forrás: a szerző saját szerkesztése)

Ha megnézzük az alábbi ábrákat (15-16. ábra) magyarázatot kapunk a lepke rajzásában 1980 és 1990 között bekövetkezett markáns változásra. Miszerint az 1985-ös rajzásadatok jelentős visszaesést mutatnak az 1983 évihez képest, ezzel párhuzamosan láthatjuk a csapadékindikátor visszaesését olyannyira, hogy 1985-ben ebben a 9. dekádban nem hullott csapadék, valamint a minimumhőmérsékletek minimuma az 1984. évben jelentősen lecsökkent, $\left(-11,7^{\circ} \mathrm{C}\right)$.
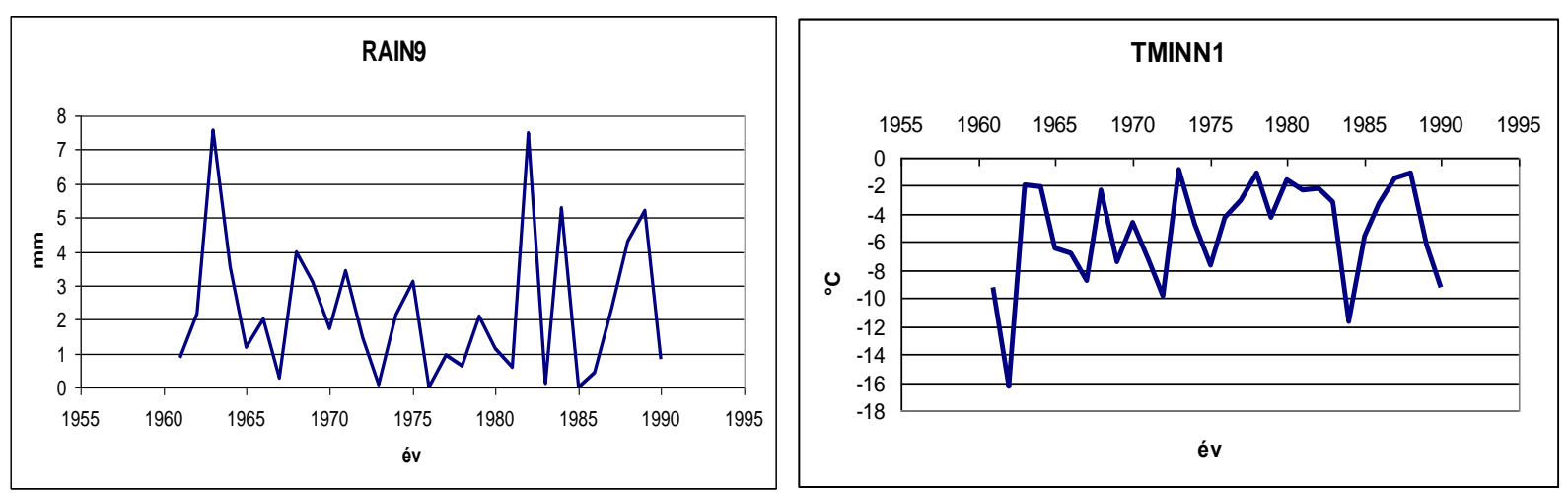

15-16. ábra A március végi csapadék és a január eleji minimumhömérséklet paraméterek értékei 1962-1991-ig

\section{$\underline{\text { Scopula nigropunctata }}$}

A S. nigropunctata esetében 14 indikátort válogattunk le, amelyek szignifikáns kapcsolatban álltak az egyedszámmal, illetve annak változásával. Ezekből eggyel, az előző év 32. dekádjának napi minimumhőmérsékleteinek átlagával (ETMIN32-vel) bővített modell bizonyult a legjobbnak a Bayes-féle Akaike-féle információs kritérium szerint $\left(\mathrm{AIC}_{\mathrm{B}}=-26,65\right)$. Az ETMIN32 indikátor korrelációs együtthatója -0,426 ( $<<0,05)$. E faj esetében azonban az alapmodellünk az Akaike információs kritérium szerint jobb volt $\left(\mathrm{AIC}_{\mathrm{B}}=-27,398\right)$. 
A 17. ábra mutatja a megfigyelt, valamint az alap- és a bővített modell által becsült egyedszámokat. Az alapmodell és a bővített modell korrelációs együtthatója is szignifikáns $\left(R_{a}=0,695 ; \mathrm{p}<0,001 ;\right.$ illetve $\left.R_{b}=0,73 ; \mathrm{p}<0,001\right)$.

$\mathrm{Az}$ elemzés eredményeképpen elmondhatjuk, hogy ez esetben az indikátorokkal nem tudtunk jelentősen javítani az alapmodellen, hiszen az $\mathrm{AIC}_{\mathrm{B}}$ értéke nem lett kisebb, így nincs értelme több változót beletenni a modellbe. A klímaindikátorokkal bővített modell eltartó kapacitása és a maximális szaporodási ráta értéke is magasabb az alapmodell értékeihez viszonyítva, sebességi tényező változása oly csekély, hogy az elhanyagolható. A modell becslésének hibatagjának értéke 0,02-dal csökkent, mely a modell előrejelzési pontosságát nem igazán befolyásolja (26. táblázat).

26. táblázat. A Scopula nigropunctata fajra vonatkozó alapmodell és a klímaindikátorral bövített modell föbb paraméterei (1962-2000)

\begin{tabular}{|l|c|c|}
\hline & alapmodell & bővített modell \\
\hline eltartó kapacitás $(K)$ & 716,8183 & 1004,7519 \\
\hline sebességi tényezö $(\theta)$ & 0,0008 & 0,0008 \\
\hline maximális szaporodási ráta $\left(R_{\max }\right)$ & 542,6733 & 597,1495 \\
\hline AIC $C_{\mathrm{B}}$ & $-27,3979$ & $-26,6525$ \\
\hline korrelációs együttható $(R)$ & 0,6947 & 0,7259 \\
\hline a becslés hibája $(R M S E)$ & 0,4173 & 0,3990 \\
\hline
\end{tabular}

Mindebből arra következtetünk, hogy az alapmodell is elég jó, kivéve az 1981-83 és 1985-86-ös gradációs években, ahol a modellek alulbecsülték az egyedszámokat.

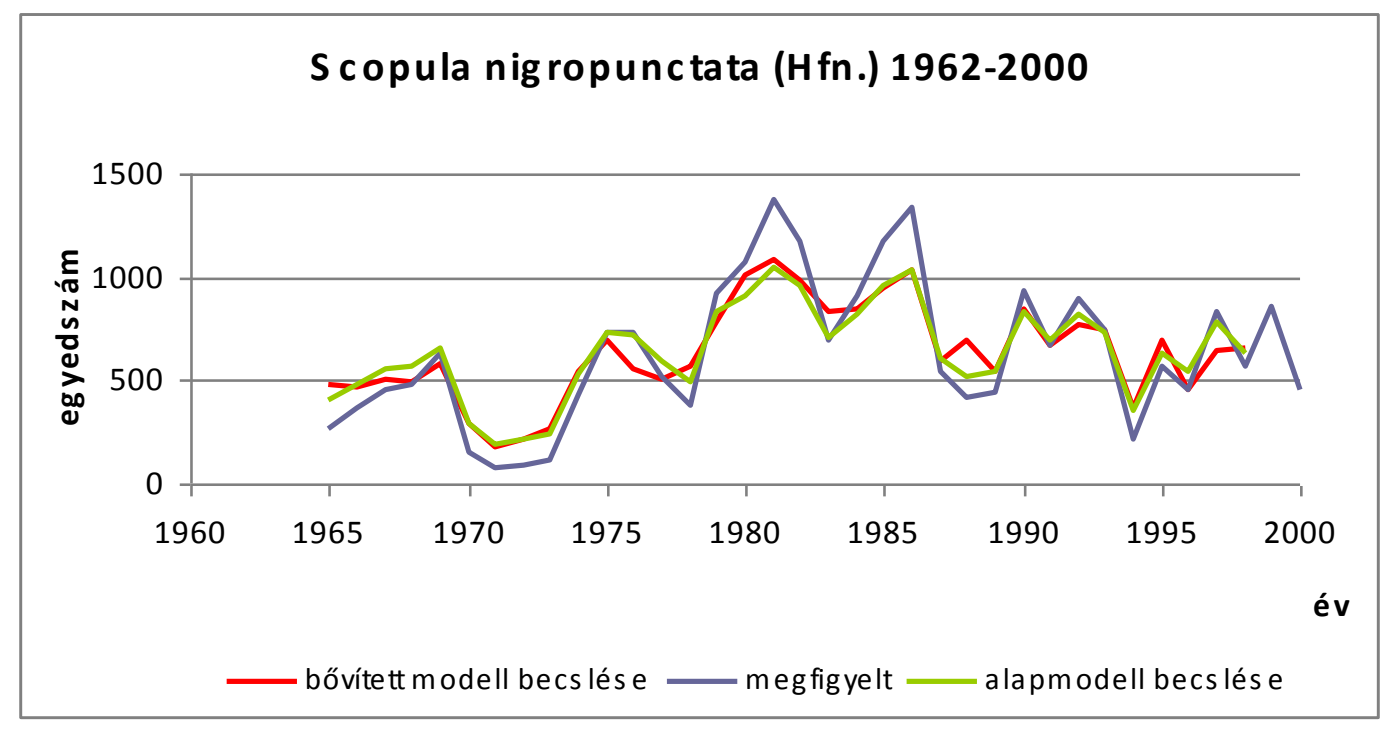

17. ábra A Scopula nigropunctata megfigyelt adataiból számított egyedszámok, valamint az alapmodel és a klímaindikátorral bövitett modell becslése 1962-2000 között (forrás: a szerzö saját szerkesztése)

\section{Pelurga comitata}

A $P$. comitata fajnál 15 indikátor mutatott szignifikáns kapcsolatot az egyedszámmal, illetve annak változásával. Két indikátorral bővítettük a modellt, az előző év 11. dekádjának napi minimumhőmérsékleteinek átlagával (ETMIN11), valamint a vizsgált év áprilisának napi 
csapadékmennyiségének átlagával (MRAIN4). A két változó Pearson-féle korrelációs együtthatója -0,369 (ETMIN11) és -0,366 (MRAIN4), mindkét esetben szignifikáns $(\mathrm{p}<0,05)$. A Bayes-féle Akaike információs kritérium szerinti $\left(\mathrm{AIC}_{\mathrm{B}}=-17,27\right)$ legjobb modell együtthatói 0,021 (ETMIN11) és -0,280 (MRAIN4). A 18. ábra mutatja a megfigyelt, valamint az alap- és a bővített modell által becsült egyedszámokat. Az alapmodell és a bővített modell korrelációs együtthatója is szignifikáns $\left(R_{a}=0,513 ; \mathrm{p}<0,001 ;\right.$ illetve $\left.R_{b}=0,62 ; \mathrm{p}<0,001\right)$. A klímaindikátorokkal bővített modell eltartó kapacitása és a maximális szaporodási ráta értéke is magasabb az alapmodell értékeihez viszonyítva, viszont a sebességi tényező változása oly csekély, hogy az elhanyagolható. A modell becslésének hibatagjának értéke 0,04-dal csökkent, mely a modell előrejelzési pontosságát nem igazán befolyásolja (27. táblázat).

27. táblázat. A Pelurga comitata fajra vonatkozó alapmodell és a klímaindikátorral bövített modell föbb paraméterei

\begin{tabular}{|l|c|c|}
\hline & alapmodell & Bővített modell \\
\hline eltartó kapacitás $(K)$ & 831,3328 & 1713,3081 \\
\hline sebességi tényező $(\theta)$ & 0,0004 & 0,0004 \\
\hline maximális szaporodási ráta $\left(R_{\max }\right)$ & 1468,2662 & 1763,9580 \\
\hline AIC $_{\mathrm{B}}$ & $-18,8419$ & $-17,2739$ \\
\hline korrelációs együttható $(R)$ & 0,5128 & 0,6213 \\
\hline a becslés hibája $(R M S E)$ & 0,5197 & 0,4743 \\
\hline
\end{tabular}

Megállapíthatjuk, hogy a megfigyelt időintervallumban a becslés illeszkedése jó, habár a 80-as években két kiugró értéket a modell jelentősen alábecsült. A bővített modell jobban illeszkedik és pontosabb elörejelzést ad az alapmodellnél.

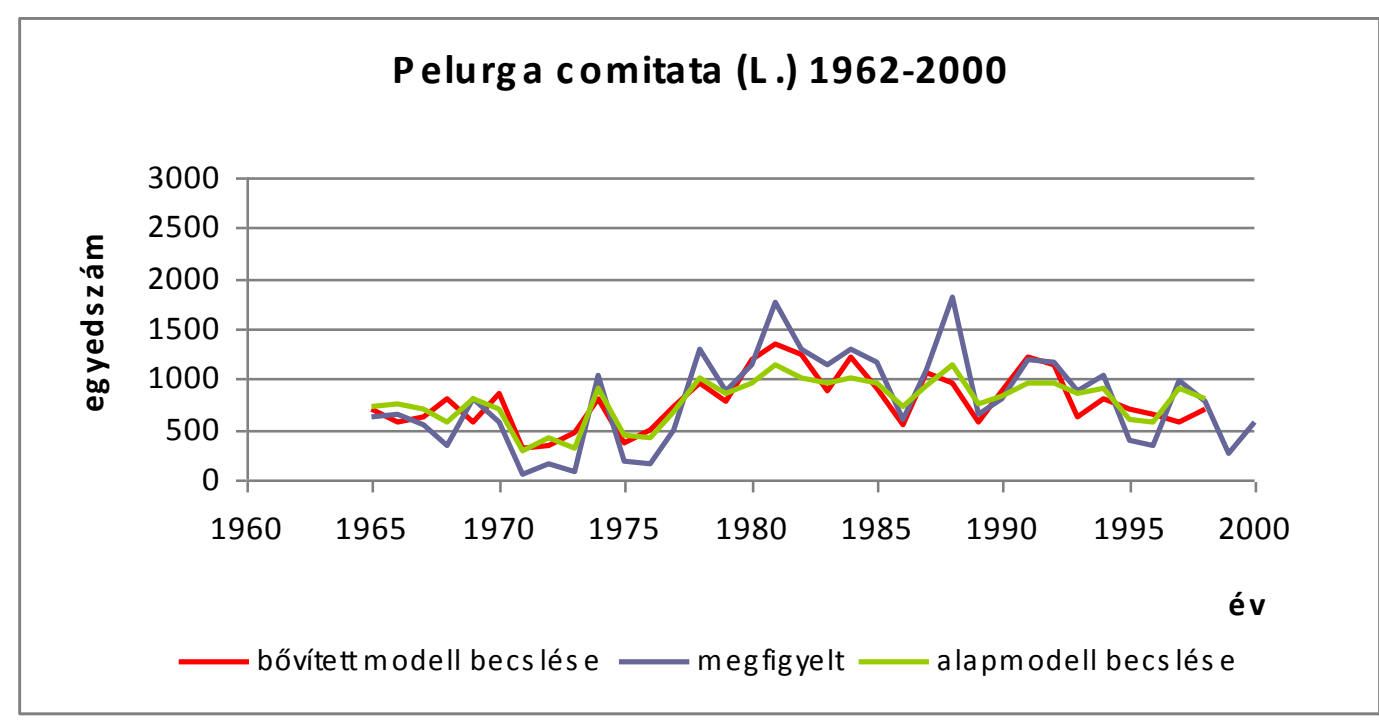

18. ábra A Pelurga comitata megfigyelt adataiból számított egyedszámok, valamint az alapmodell és a klímaindikátorral bővitett modell becslése (forrás: a szerzö saját szerkesztése) 


\section{Eulithis pyraliata}

Az E. pyraliata esetében 13 indikátort választottunk, amelyek szignifikáns kapcsolatban álltak az egyedszámmal, illetve annak változásával, melyek közül 3 került be a legjobb bővített modellbe. Ezeket az indikátorokat a 28. táblázat tartalmazza.

28. táblázat Az Eulithis pyraliata esetében leválogatott indikátorok közül a bővített modellbe beválogatott indikátorok Pearson-féle korrelációs együtthatói (R) és szignifikancia értékei

\begin{tabular}{|c|c|}
\hline Indikátor & Korrelációs együttható (R) \\
\hline ERAIN9 & $0,364 *$ \\
\hline ERAIN3 & $0,377^{*}$ \\
\hline ERAIN34 & $0,379 *$ \\
\hline \multicolumn{2}{|c|}{$\begin{array}{l}\text { *p } \leq 0,05 \text { szinten szignifikáns } \\
\text { ERAIN3: előző év 3. dekádjának napi csapadékmennyiségének átlaga } \\
\text { ERAIN9: előző év 9. dekádjának napi csapadékmennyiségének átlaga } \\
\text { ERAIN34: elöző év } 34 \text {. dekádjának napi csapadékmennyiségének átlaga }\end{array}$} \\
\hline
\end{tabular}

Az alapmodellünket tehát az előző év 3., 9., és 34. dekádjának napi csapadékmennyiségének átlagaival bővítettük, így kaptuk a minimális Bayes-féle Akaike információs kritériumot $\left(\mathrm{AIC}_{\mathrm{B}}=-37,093\right)$. A klímaindikátorok együtthatóit a 29. táblázatban mutatjuk be.

29. táblázat $\mathrm{A}$ legalacsonyabb $\mathrm{AIC}_{\mathrm{B}}$ értékkel definiált legjobb modell együtthatói

\begin{tabular}{|c|c|c|}
\hline ERAIN9 & ERAIN3 & ERAIN34 \\
\hline 0,150 & 0,059 & 0,085 \\
\hline
\end{tabular}

A 19. ábra mutatja a megfigyelt valamint az alap- és a bővített modell által becsült egyedszámokat. Az alapmodell és a bővített modell korrelációs együtthatója is szignifikáns $\left(R_{a}=0,804 ; \mathrm{p}<0,001 ;\right.$ illetve $\left.R_{b}=0,942 ; \mathrm{p}<0,001\right)$. A klímaindikátorokkal bővített modell eltartó kapacitása és sebességi tényezője alacsonyabb, viszont a maximális szaporodási ráta értéke magasabb az alapmodell értékeihez viszonyítva. A modell becslésének hibatagjának értéke alacsonyabb, ami pontosabb modellt jelent (30. táblázat).

30. táblázat. Az Eulithis pyraliata fajra vonatkozó alapmodell és a klímaindikátorral bövített modell föbb paraméterei (1962-2000)

\begin{tabular}{|l|c|c|}
\hline & alapmodell & Bővített modell \\
\hline eltartó kapacitás $(K)$ & 1240,8098 & 210,6271 \\
\hline sebességi tényező $(\theta)$ & 0,0007 & 0,0005 \\
\hline maximális szaporodási ráta $\left(R_{\max }\right)$ & 329,9609 & 585,2014 \\
\hline AIC $\mathrm{B}$ & $-20,4800$ & $-37,0939$ \\
\hline korrelációs együttható $(R)$ & 0,8027 & 0,9421 \\
\hline a becslés hibája $(R M S E)$ & 0,5064 & 0,2847 \\
\hline
\end{tabular}

Az ábrán is látható, hogy mind az alapmodell, mind a bővített modell illeszkedése meglehetősen jó, a bővített modell a kiugró értékeknél is jól becsül. 


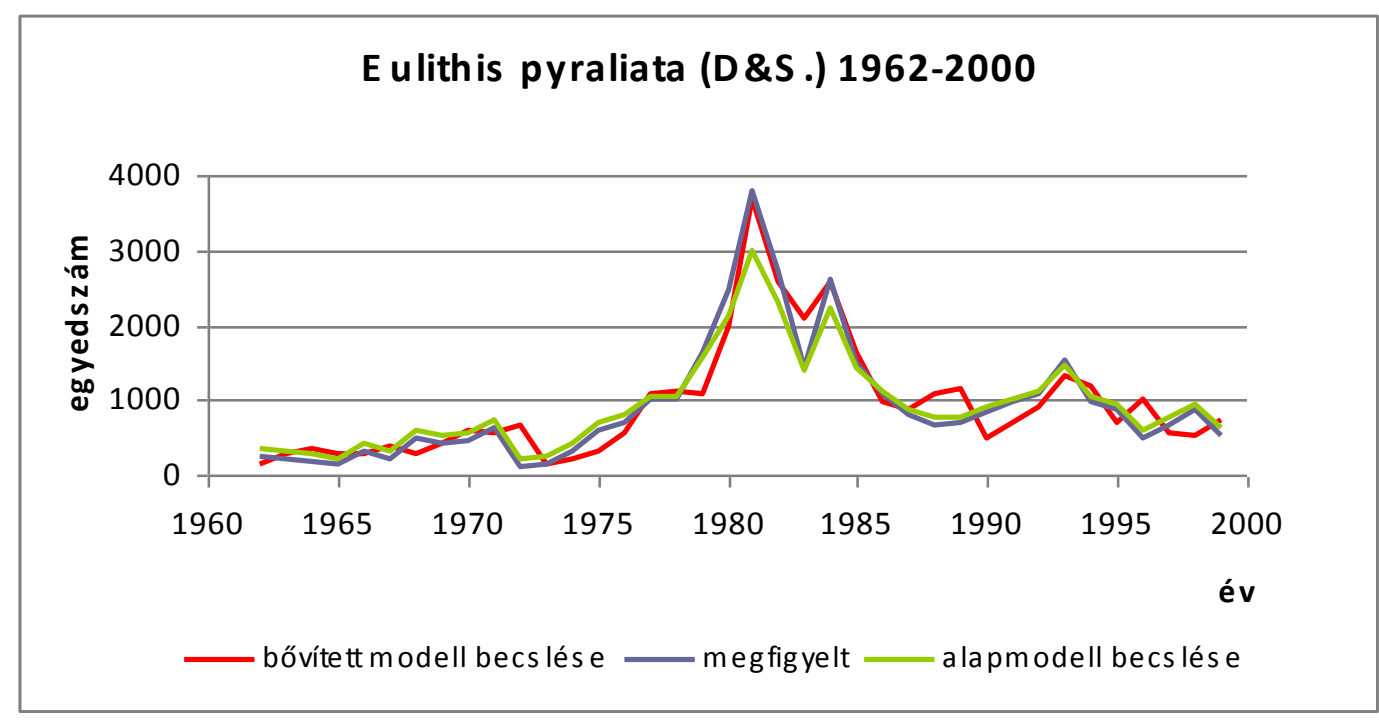

19. ábra Az Eulithis pyraliata megfigyelt adataiból számított egyedszámok, valamint az alapmodell és a klímaindikátorral bővitett modell becslése 1962-2000 között (forrás: a szerzö saját szerkesztése)

\subsubsection{Fökomponens-regressziós modellek}

Az előző fejezetben tárgyalt modellek előállításához olyan indikátorhalmazból válogattunk bele az alapmodellbe további magyarázó változókat, amelynek elemei egymástól sok esetben nem függetlenek. A Bayes-féle Akaike információs kritérium segítségével kerestük azt a legjobban magyarázó modellt, amelynek magyarázó változóinak (és optimalizálandó együtthatóinak) száma a modellt javító erejéhez képest nem nő túlságosan. Ez azonban azt eredményezte, hogy kevés új magyarázó változót tudtunk bevonni a modellbe. Felmerült tehát annak igénye, hogy a változók számát főkomponens analízissel (PCA) csökkentsük olyan új faktorok előállításával, hogy azok a varianciát minél nagyobb hányadban magyarázzák, és emellett függetlenek legyenek. A következőkben az így kapott főkomponens modelleket ismertetjük.

\section{Operophtera brumata}

Az O. brumata esetében az PCA-val 17 fökomponens kaptunk, melyek a teljes variancia 97,4\%-át magyarázzák, ezek közül négy főkomponens mutat szignifikáns lineáris kapcsolatot az egyed számmal, illetve annak változásával. Az alapmodell bővítéséhez azt főkomponenst vettük bele a modellbe, amelynek az RMSE hibáját minimalizálva a legkisebb Bayes-féle Akaike információs kritériummal rendelkező bővített modellt sikerült előállítani. Ez alapján az O. brumata faj esetében egyetlen, mégpedig a PC6-os változót emeltük be a modellbe. 
A PC6 főkomponens a következő indikátorokkal mutat erős korrelációt a magas loadingok alapján:

$\rightarrow$ ETATL8: előző év 8. dekádjának napi középhőmérsékleteinek átlaga

$\rightarrow$ ETMAX8: előző év 8. dekádjának napi maximumhőmérsékleteinek átlaga

$\rightarrow$ ETMIN8: előző év 8. dekádjának napi minimumhőmérsékleteinek átlaga

$\rightarrow$ ETMAXX8: előző év 8. dekádjának napi maximumhőmérsékleteinek maximuma

$\rightarrow$ MRAIN8: vizsgált év 8. hónapjának napi csapadékmennyiségének átlaga

$\rightarrow$ ETMAXX23: előző év 23. dekádjának napi maximumhőmérsékleteinek maximuma

Az alapmodellünknek a PC6 főkomponenssel, 0,245 együtthatóval történt bővítése után a Bayes-féle Akaike-féle információs kritérium szerint $\left(\mathrm{AIC}_{\mathrm{B}}=-7,13\right)$ ez a modell volt a legjobb.

A 20. ábra mutatja a megfigyelt, valamint az alap- és a fökomponenssel bővített modell által becsült egyedszámokat. Az alapmodell és a fökomponenssel bővített modell korrelációs együtthatója is szignifikáns $\left(R_{a}=0,863 ; \mathrm{p}<0,001 ;\right.$ illetve $\left.R_{f b}=0,916 ; \mathrm{p}<0,001\right)$. A klímaindikátorokkal bővített modell eltartó kapacitása és a maximális szaporodási ráta értéke is magasabb, míg a sebességi tényezője alacsonyabb az alapmodell értékeihez viszonyítva. A modell becslésének hibatagjának értéke alacsonyabb, ami pontosabb modellt jelent (31. ábra).

31. táblázat. AZ Operophtera brumatafajra vonatkozó alapmodell és a fókomponenssel bövitett modell föbb paraméterei (1962-2000)

\begin{tabular}{|l|c|c|}
\hline & alapmodell & fókomponenssel bövített modell \\
\hline eltartó kapacitás $(K)$ & 6,4836 & 7,1584 \\
\hline sebességi tényező $(\theta)$ & 0,0008 & 0,0007 \\
\hline maximális szaporodási ráta $\left(R_{\max }\right)$ & 281,5237 & 437,6733 \\
\hline AIC $\mathrm{B}$ & $-0,6492$ & $-7,1316$ \\
\hline korrelációs együttható $(R)$ & 0,8602 & 0,9156 \\
\hline a becslés hibája $(R M S E)$ & 0,8286 & 0,6583 \\
\hline
\end{tabular}

Mind az alapmodell, mind a főkomponenssel bővített modell többnyire jól illeszkedik a megfigyelt egyedszámokra, bár a kiugró értékeket mindkét modell nagyon alulbecsüli, a főkomponenssel bővített modell hibája egyes ilyen esetekben nagyobb is. 


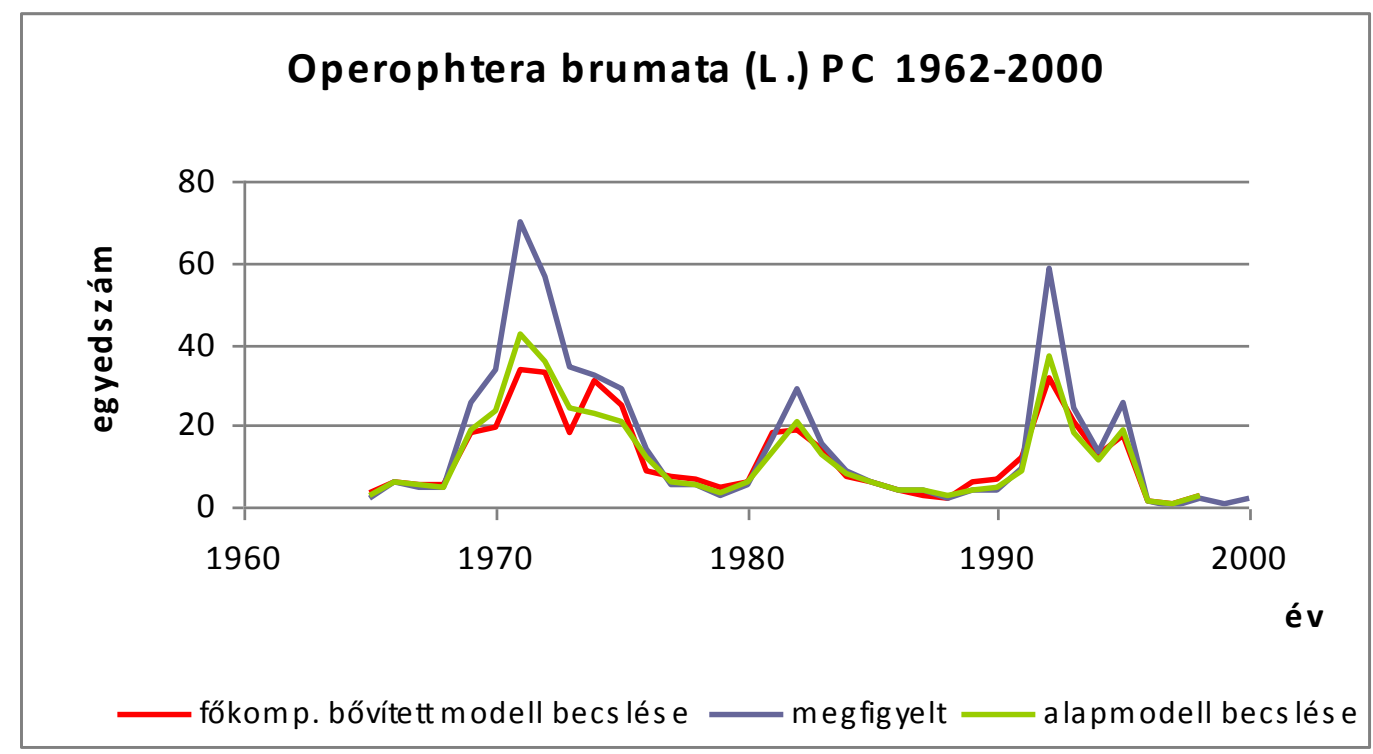

20. ábra Az Operophtera brumata megfigyelt adataiból számitott egyedszám, valamint az alapés a fökomponenssel bövitett modell becslése (forrás: a szerző saját szerkesztése)

\section{$\underline{\text { Erannis defoliaria }}$}

Az E. defoliaria esetében a fökomponens analízis során kapott föfaktorok közül a változók 11 komponenssel mutattak szignifikáns kapcsolatot. A modellbe beillesztést követően, a becslési hiba kiszámítása után két fökomponenst választottunk, melyek együttes bevonásával megkaptuk a megfigyeléshez legjobban illeszkedő modellt. A két fökomponens PC2 $(R=0,272$; $\mathrm{p}<0,1)$ és a PC11 $(R=-0,198 ; \mathrm{SL}=0,225)$.

A modellbe bevett fökomponensek loadingjaik alapján a következő indikátorokkal vannak magas korrelációban:

\section{PC2}

$\rightarrow$ TATL11: vizsgált év 11. dekádjának napi középhőmérsékleteinek átlaga

$\rightarrow$ RAIN31: vizsgált év 31. dekádjának napi csapadékmennyiségének átlaga

$\rightarrow$ RAIN36: vizsgált év 36. dekádjának napi csapadékmennyiségének átlaga

$\rightarrow$ TMAXX23: vizsgált év 23. dekádjának napi maximumhőmérsékleteinek maximuma

$\rightarrow$ MTMAXX8: vizsgált év 8. hónapjának napi maximumhőmérsékleteinek maximuma

$\rightarrow$ MTMINN4: vizsgált év 4. hónapjának napi minimumhőmérsékleteinek minimuma

\section{PC11}

$\rightarrow$ RAIN31: vizsgált év 31. dekádjának napi csapadékmennyiségének átlaga

$\rightarrow$ MTMINN4: vizsgált év 4. hónapjának napi minimumhőmérsékleteinek minimuma

$\rightarrow$ EMRAIN3: előző év 3. hónapjának napi csapadékmennyiségének átlaga 
Az alapmodellünket a PC2 és a PC11 főkomponensekkel történt bővítés után a Bayesféle Akaike-féle információs kritérium szerint $\left(\mathrm{AIC}_{\mathrm{B}}=-13,970\right)$ a legjobbnak találtuk. $\mathrm{A}$ fökomponensek együtthatói 0,240 (PC2) és -0,189 (PC11).

A 21. ábra mutatja a megfigyelt, valamint az alap- és a főkomponenssel bővített modell által becsült egyedszámokat. Az alapmodell és a főkomponenssel bővített modell korrelációs együtthatója is szignifikáns $\left(R_{a}=0,920 ; \mathrm{p}<0,001 ;\right.$ illetve $\left.R_{f b}=0,946 ; \mathrm{p}<0,001\right)$. A klímaindikátorokkal bővített modell eltartó kapacitása és sebességi tényezője is alacsonyabb az alapmodell értékeihez viszonyítva, viszont a maximális szaporodási ráta értéke magasabb. A modell becslésének hibatagjának értéke alacsonyabb, ami pontosabb modellt jelent (32. táblázat).

32. táblázat. Az Erannis defoliaria megfigyelt adataiból készült alapmodell és a fökomponensekkel bővitett modell fóbb paraméterei (1962-2000)

\begin{tabular}{|l|c|c|}
\hline & alapmodell & fökomponenssel bővített modell \\
\hline eltartó kapacitás $(K)$ & 5,1765 & 3,3144 \\
\hline sebességi tényező $(\theta)$ & 0,0006 & 0,0004 \\
\hline maximális szaporodási ráta $\left(R_{\max }\right)$ & 673,2240 & 849,3813 \\
\hline AIC $\mathrm{B}$ & $-11,6050$ & $-13,9702$ \\
\hline korrelációs együttható $(R)$ & 0,9195 & 0,9459 \\
\hline a becslés hibája $(R M S E)$ & 0,6256 & 0,5162 \\
\hline
\end{tabular}

A leválogatott főkomponensekkel jól illeszkedő modellt kaptunk, melynek csak extrém magas egyedszám esetén volt a becslése jóval alacsonyabb a megfigyeltnél.

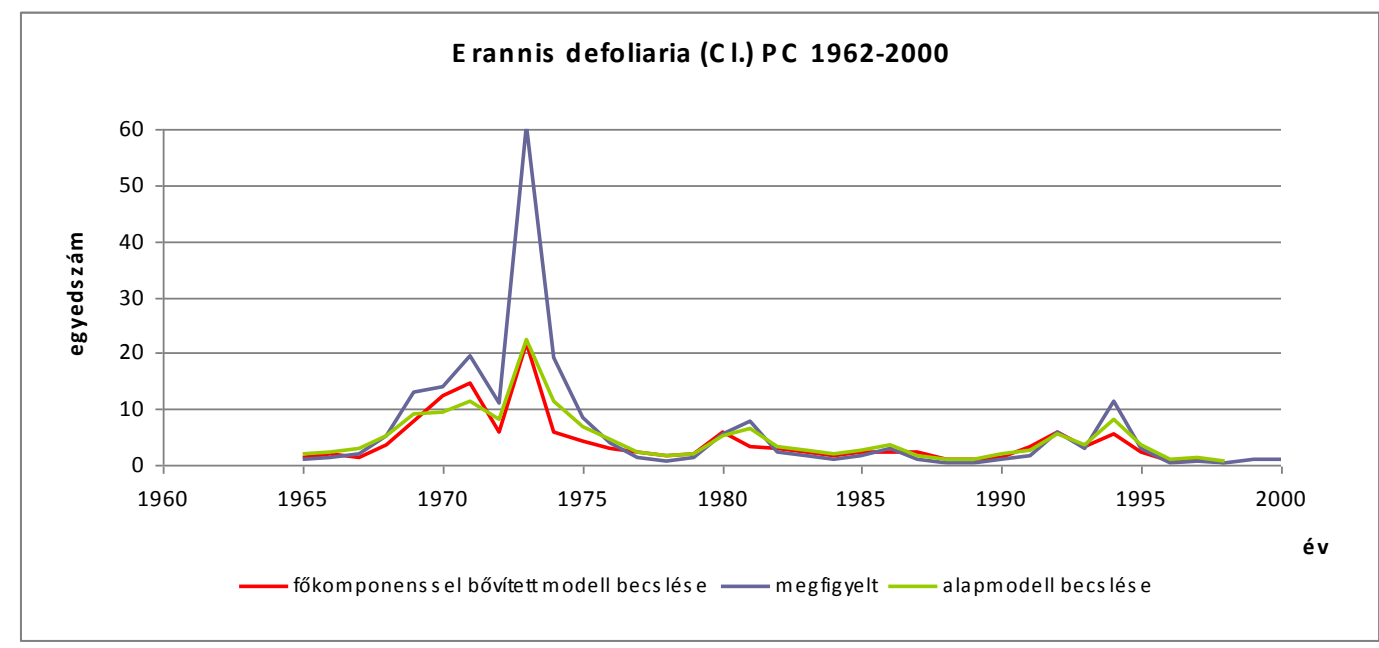

21. ábra Az Erannis defoliaria megfigyelt adataiból számitott egyedszám, valamint az alapés a fökomponensekkel bövitett modell becslése (forrás: a szerzö saját szerkesztése)

\section{Colotois pennaria}

A C. pennaria PCA elemzésének eredményeként az indikátorok lineáris kombinációiból 8 fökomponenst képeztünk. A Bayes-féle Akaike információs kritérium $\left(\mathrm{AIC}_{\mathrm{B}}=0,654\right) 3$ fökomponens, a PC1, PC2 és a PC3 együttes bevonásával mutatta a legkisebb értéket (33. táblázat). 
Táblázat 33. A Colotois pennaria esetében leválogatott fökomponensek közül az egyedszámmal, illetve annak változásával bővített modellbe beválogatott fókomponensek Pearson-féle korrelációs együtthatói (R) és szignifikancia értékei

\begin{tabular}{|c|c|}
\hline Főkomponens & Korrelációs együttható (R) \\
\hline PC1 & $0,273+$ \\
\hline PC2 & $-0,027 *$ \\
\hline PC3 & 0,397 n.s. \\
\hline$+\mathrm{p} \leq 0,1$ szinten szignifikáns $* \mathrm{p} \leq 0,05$ szinten szignifikáns
\end{tabular}

A modellbe bevett főkomponensek loadingjaik alapján a következő indikátorokkal vannak magas korrelációban:

\section{PC1:}

$\rightarrow$ TMIN32: vizsgált év 32. dekádjának napi minimumhőmérsékleteinek átlaga

$\rightarrow$ TMAX11: vizsgált év 11. dekádjának napi maximumhőmérsékleteinek átlaga

$\rightarrow$ ETMAX31: előző év 31. dekádjának napi maximumhőmérsékleteinek átlaga

$\rightarrow$ ETMAXX11: előző év 11. dekádjának napi maximumhőmérsékleteinek maximuma

$\rightarrow$ ETMAXX36: előző év 36. dekádjának napi maximumhőmérsékleteinek maximuma

$\rightarrow$ EMTMAXX4: előző év 4. hónapjának napi maximumhőmérsékleteinek maximuma

$\rightarrow$ EMTMIN11: előző év 11. hónapjának napi minimumhőmérsékleteinek átlaga

$\rightarrow$ EMTMINN12: előző év 12. hónapjának napi minimumhőmérsékleteinek minimuma

\section{PC2:}

$\rightarrow$ TMAX34: vizsgált év 34. dekádjának napi maximumhőmérsékleteinek átlaga

$\rightarrow$ ETATL34: előző év 34. dekádjának napi középhőmérsékleteinek átlaga

$\rightarrow$ ETMAX31: előző év 31. dekádjának napi maximumhőmérsékleteinek átlaga

$\rightarrow$ EMTMAXX4: előző év 4. hónapjának napi maximumhőmérsékleteinek maximuma

$\rightarrow$ EMTMINN12: előző év 12. hónapjának napi minimumhőmérsékleteinek minimuma

\section{PC3:}

$\rightarrow$ ERAIN6: előző év 6. dekádjának napi csapadékmennyiségének átlaga

$\rightarrow$ ERAIN23: előző év 23. dekádjának napi csapadékmennyiségének átlaga

$\rightarrow$ MRAIN8: vizsgált év 8. hónapjának napi csapadékmennyiségének átlaga

$\rightarrow$ EMRAIN2: előző év 2. hónapjának napi csapadékmennyiségének átlaga

A legjobb modell együtthatóit a 34. táblázat mutatja.

34. táblázat $\mathrm{A}$ legalacsonyabb $\mathrm{AIC}_{\mathrm{B}}$ értékkel rendelkező legjobb modell magyarázó változóinak együtthatói

\begin{tabular}{|c|c|c|}
\hline PC1 & PC2 & PC3 \\
\hline 0,637 & 0,130 & 0,433 \\
\hline
\end{tabular}

A 22. ábra mutatja a megfigyelt, valamint az alap- és a főkomponenssel bővített modell által becsült egyedszámokat. Az alapmodell és a fökomponenssel bővített modell korrelációs 
együtthatója is szignifikáns $\left(R_{a}=0,451 ; \mathrm{p}<0,01 ;\right.$ illetve $\left.R_{f b}=0,872 ; \mathrm{p}<0,001\right)$ is. A klímaindikátorokkal bővített modell eltartó kapacitása és sebességi tényezője is alacsonyabb az alapmodell értékeihez viszonyítva, viszont a maximális szaporodási ráta értéke magasabb. A modell becslésének hibatagjának értéke alacsonyabb, ami pontosabb modellt jelent (35. táblázat).

35. táblázat. A Colotois pennaria megfigyelt adataiból készült alapmodell és a fökomponensekkel bövitett modell föbb paraméterei (1962-2000)

\begin{tabular}{|l|c|c|}
\hline & alapmodell & fökomponenssel bövített modell \\
\hline eltartó kapacitás $(K)$ & 4,3045 & 0,8814 \\
\hline sebességi tényezö $(\theta)$ & 0,0007 & 0,0006 \\
\hline maximális szaporodási ráta $\left(R_{\max }\right)$ & 723,3058 & 798,5542 \\
\hline AIC ${ }_{\mathrm{B}}$ & 15,7554 & 0,6540 \\
\hline korrelációs együttható $(R)$ & 0,4514 & 0,8690 \\
\hline a becslés hibája $(R M S E)$ & 1,2618 & 0,6989 \\
\hline
\end{tabular}

Az 1962-2000 között a kiugró értékek éveinek elhagyásával, az 1972-2000 közötti évekre készített modellbe már csak az első főkomponenst, a PC1-et tudtuk bevonni. A modellünk becslése a megfigyeléssel ugyan magasabb korrelációt mutatott $\left(R_{a}=0,478 ; \mathrm{p}<0,01\right.$; illetve $\left.R_{f b}=0,583 ; \mathrm{p}<0,001\right)$ az alapmodellnél kapott Bayes-féle Akaike információs kritériumot nem tudtuk tovább csökkentei $\left(\mathrm{AIC}_{\mathrm{B}}=-5,07 ; \mathrm{AIC}_{\mathrm{B}}=-5,505\right)$. A PC1 fökomponens együtthatója 0,226 .

A 23. ábrán megfigyelhetjük, hogy a főkomponenssel bővített modell az 1973 előtti nagyon kiugró értéket jobban magyarázza, viszont ezzel együtt a többi évre vonatkolzó becsések erősen torzulnak. A bővített modell eltartó kapacitása magasabb, a maximális szaporodási ráta értéke alacsonyabb az alapmodell értékeihez viszonyítva. A sebességi tényező változása oly csekély, hogy az elhanyagolható.A modell becslésének hibatagjának értéke alacsonyabb, ami pontosabb modellt jelent (36. táblázat).

36. táblázat. A Colotois pennaria fajra vonatkozó alapmodell és a a fökomponensekkel bövített modell föbb paraméterei (1972-2000)

\begin{tabular}{|l|c|c|}
\hline & alapmodell & főkomponenssel bővített modell \\
\hline eltartó kapacitás $(K)$ & 2,9811 & 3,3548 \\
\hline sebességi tényezö $(\theta)$ & 0,0007 & 0,0007 \\
\hline maximális szaporodási ráta $\left(R_{\max }\right)$ & 811,1516 & 646,1422 \\
\hline AIC $\mathrm{B}$ & $-5,5030$ & $-5,0681$ \\
\hline korrelációs együttható $(R)$ & 0,4780 & 0,5834 \\
\hline A becslés hibája $(R M S E)$ & 0,6507 & 0,6016 \\
\hline
\end{tabular}

Az 1973-tól elkészített modell az alapmodellel együtt jól illeszkedik a megfigyelésekre. (23. ábra). 

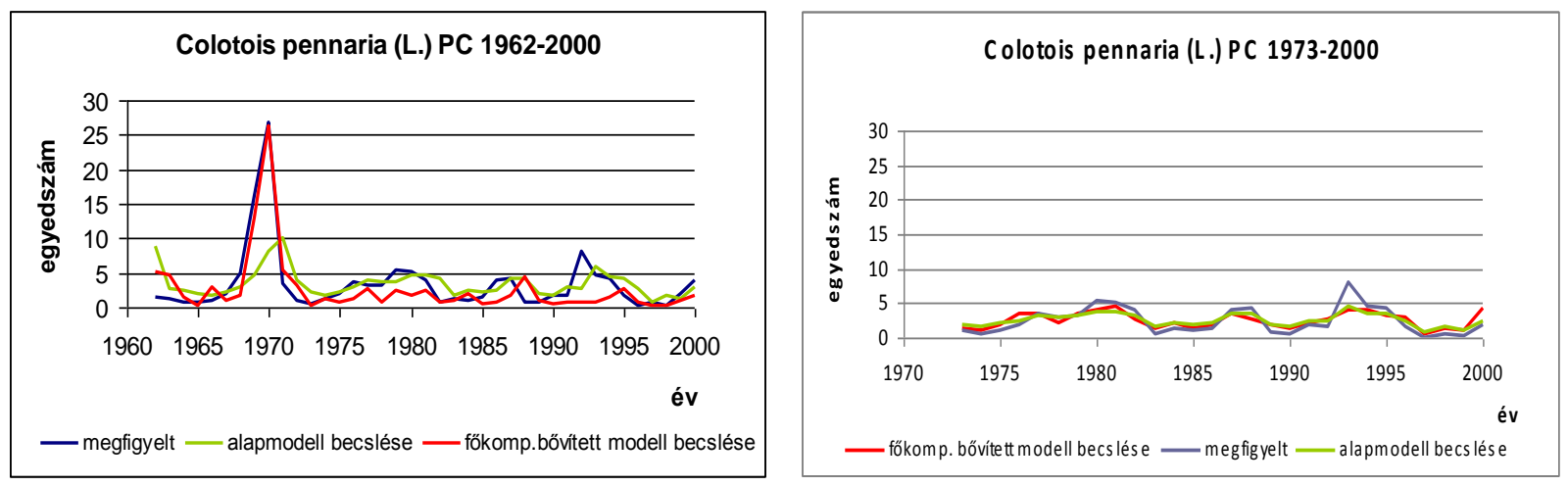

22-23. ábra A Colotois pennaria megfigyelt adataiból számitott egyedszám, valamint az alap-és a fökomponensekkel bővitett modell becslése (forrás: a szerző saját szerkesztése)

\section{$\underline{\text { Erannis aurantiaria }}$}

Az E. aurantiaria 1965-2000 között futtatott főkomponens analízise során a 11 fökomponens közül csupán egy fökomponenst (PC5, együtthatója -0,331) bevonva kaptunk olyan jól illeszkedő modellt, melynek a Bayes-féle Akaike információs kritériuma minimális volt $\left(\mathrm{AIC}_{\mathrm{B}}=-7,66\right)$.

A modellbe bevett PC5 főkomponens loadingjai alapján a következő indikátorokkal van magas korrelációban:

$\rightarrow$ ERAIN36: előző év 36. dekádjának napi csapadékmennyiségének átlaga

$\rightarrow$ MTMIN5: vizsgált év 5. hónapjának napi minimumhőmérsékleteinek átlaga

$\rightarrow$ TMIN14: vizsgált év 14. dekádjának napi minimumhőmérsékleteinek átlaga

A 24. ábra mutatja a megfigyelt, valamint az alap- és a főkomponenssel bővített modell által becsült egyedszámokat. Az alapmodell korrelációs együtthatója nem szignifikáns $\left(R_{a}=0,151 ; \mathrm{p}=0,38\right)$, míg a fókomponenssel bővített modell korrelációs együtthatója szignifikáns $\left(R_{f b}=0,468 ; \mathrm{p}<0,001\right)$. Az ábrán megfigyelt időintervallumban a becslés illszkedése megfelelő, de a kiugró értékeket (pl. 1994-ben) mindkét modell jelentősen alulbecsülte. A klímaindikátorokkal bővített modell eltartó kapacitása és a maximális szaporodási ráta értéke is alacsonyabb az alapmodell értékeihez viszonyítva, viszont sebességi tényező változása oly csekély, hogy az elhanyagolható. A modell becslésének hibatagjának értéke alacsonyabb, ami pontosabb modellt jelent (37. táblázat).

37. táblázat. Az Erannis aurantiaria fajra vonatkozó alapmodell és a fökomponenssel bővitett modell föbb paraméterei (1962-2000)

\begin{tabular}{|l|c|c|}
\hline & alapmodell & fökomponenssel bövített modell \\
\hline eltartó kapacitás $(K)$ & 2,4852 & 2,4174 \\
\hline sebességi tényező $(\theta)$ & 0,0011 & 0,0011 \\
\hline maximális szaporodási ráta $\left(R_{\max }\right)$ & 762,3978 & 657,8019 \\
\hline AIC & $-6,5561$ & $-7,6576$ \\
\hline korrelációs együttható $(R)$ & 0,2126 & 0,4682 \\
\hline a becslés hibája $(R M S E)$ & 0,6910 & 0,6245 \\
\hline
\end{tabular}


Ha a vizsgálatot csak a kiugró értékig végezzük, az 1965-1993-ig tartó intervallumra, akkor is a PC5 főkomponenst tudtuk bevenni a modellbe. E bővített modellnél a Bayes-féle Akaike-féle információs kritérium $\mathrm{AIC}_{\mathrm{B}}=-12,38$ volt. A magyarázó főkomponens együtthatója a $-0,394$. Ebben az esetben csak a bővített modell volt $\left(R_{f b}=0,642 ; \mathrm{p}<0,001\right)$ szignifikáns, az alapmodell nem $\left(R_{a}=0,275 ; \mathrm{p}=0,16\right)$. A klímaindikátorokkal bővített modell eltartó kapacitása és a maximális szaporodási ráta értéke is alacsonyabb az alapmodell értékeihez viszonyítva, viszont a sebességi tényező változása oly csekély, hogy az elhanyagolható. A modell becslésének hibatagjának értéke alacsonyabb, ami pontosabb modellt jelent (38. táblázat).

38. táblázat. Az Erannis aurantiaria fajra vonatkozó alapmodell és a fökomponenssel bövített modell föbb paraméterei (1965-1993)

\begin{tabular}{|l|c|c|}
\hline & alapmodell & fökomponenssel bövített modell \\
\hline eltartó kapacitás $(K)$ & 2,4242 & 2,2678 \\
\hline sebességi tényezó $(\theta)$ & 0,0011 & 0,0011 \\
\hline maximális szaporodási ráta $\left(R_{\max }\right)$ & 697,7027 & 508,6370 \\
\hline AIC $\mathrm{B}_{\mathrm{B}}$ & $-8,7955$ & $-12,3844$ \\
\hline korrelációs együttható $(R)$ & 0,2787 & 0,6416 \\
\hline a becslés hibája $(R M S E)$ & 0,5689 & 0,4538 \\
\hline
\end{tabular}

A 25. ábrán láthatjuk, hogy e fökomponenssel bővített modell jobban illeszkedik a megfigyelésekre, mint az alapmodell.
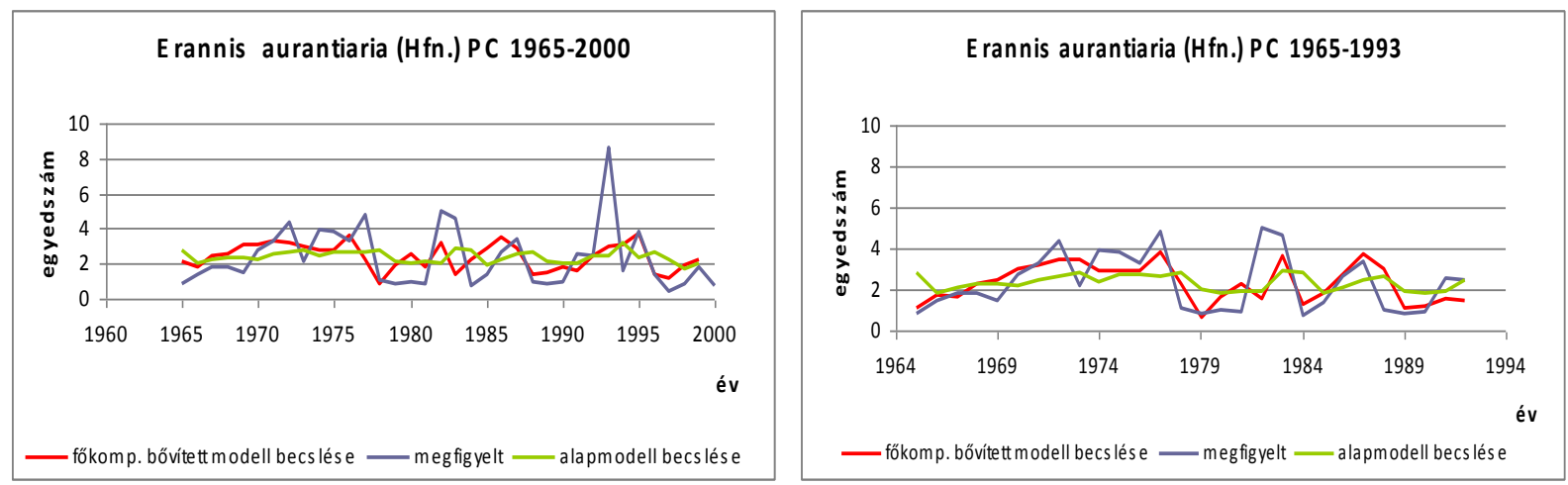

24-25. ábra Az Erannis aurantiaria megfigyelt adataiból számitott egyedszám, valamint az alap- és a fökomponenssel bövitett modell becslése 1965-2000 és 1965-1993 között (forrás: a szerzö saját szerkesztése)

\section{$\underline{\text { Idaea dimidiata }}$}

Az I. dimidiata esetében tíz fökomponenst kaptunk, ezekből kettő, a PC4 és PC7 főkomponens (-0,236 (PC4) és 0,165 (PC7) együtthatókkal való) bevonásával jutottunk a Bayesféle Akaike információs kritérium szerinti legjobb modellhez $\left(\mathrm{AIC}_{\mathrm{B}}=-27,303\right)$.

A PC4, illetve a PC7 fökomponensek loadingjaik alapján a következő indikátorokkal vannak magas korrelációban: 


\section{PC4:}

$\rightarrow$ ERAIN26: előző év 26. dekádjának napi csapadékmennyiségének átlaga

$\rightarrow$ ETMAX31: előző év 31. dekádjának napi maximumhőmérsékleteinek átlaga

$\rightarrow$ EMTMIN4: előző év 4. hónapjának napi minimumhőmérsékleteinek átlaga

$\rightarrow$ ETMIN11: előző év 11. dekádjának napi minimumhőmérsékleteinek átlaga

$\rightarrow$ ETMIN18: előző év 18. dekádjának napi minimumhőmérsékleteinek átlaga

$\rightarrow$ ETMINN1: előző év 1. dekádjának napi minimumhőmérsékleteinek minimuma

\section{PC7:}

$\rightarrow$ RAIN9: vizsgált év 9. dekádjának napi csapadékmennyiségének átlaga

$\rightarrow$ MRAIN3: vizsgált év 3. hónapjának havi csapadékmennyiségének átlaga

A 24. ábra mutatja a megfigyelt, valamint az alap- és a fökomponenssel bővített modell által becsült egyedszámokat. Az alapmodell és a fökomponenssel bővített modell korrelációs együtthatója is szignifikáns $\left(R_{a}=0,767 ; \mathrm{p}<0,001 ; R_{f b}=0,881 ; \mathrm{p}<0,001\right)$. A klímaindikátorokkal bővített modell eltartó kapacitása alacsonyabb, viszont a maximális szaporodási ráta értéke magasabb az alapmodell értékeihez viszonyítva. A sebességi tényező változása oly csekély, hogy az elhanyagolható. A modell becslésének hibatagjának értéke alacsonyabb, ami pontosabb modellt jelent (39. táblázat).

39. táblázat. Az Idaea dimidiata fajra vonatkozó alapmodell és a fökomponensekkel bövített modell föbb paraméterei (1962-2000)

\begin{tabular}{|l|c|c|}
\hline & alapmodell & fökomponenssel bövített modell \\
\hline eltartó kapacitás $(K)$ & 1076,3944 & 806,8467 \\
\hline sebességi tényezö $(\theta)$ & 0,0008 & 0,0008 \\
\hline maximális szaporodási ráta $\left(R_{\max }\right)$ & 350,9609 & 413,5124 \\
\hline $\mathrm{AIC}_{\mathrm{B}}$ & $-20,5769$ & $-27,3038$ \\
\hline korrelációs együttható $(R)$ & 0,7666 & 0,8806 \\
\hline a becslés hibája $(R M S E)$ & 0,4971 & 0,3667 \\
\hline
\end{tabular}

A két főkomponenssel bővített modell becslése meglehetősen jó, a modell jól tükrözi az értékek ingadozásait. 


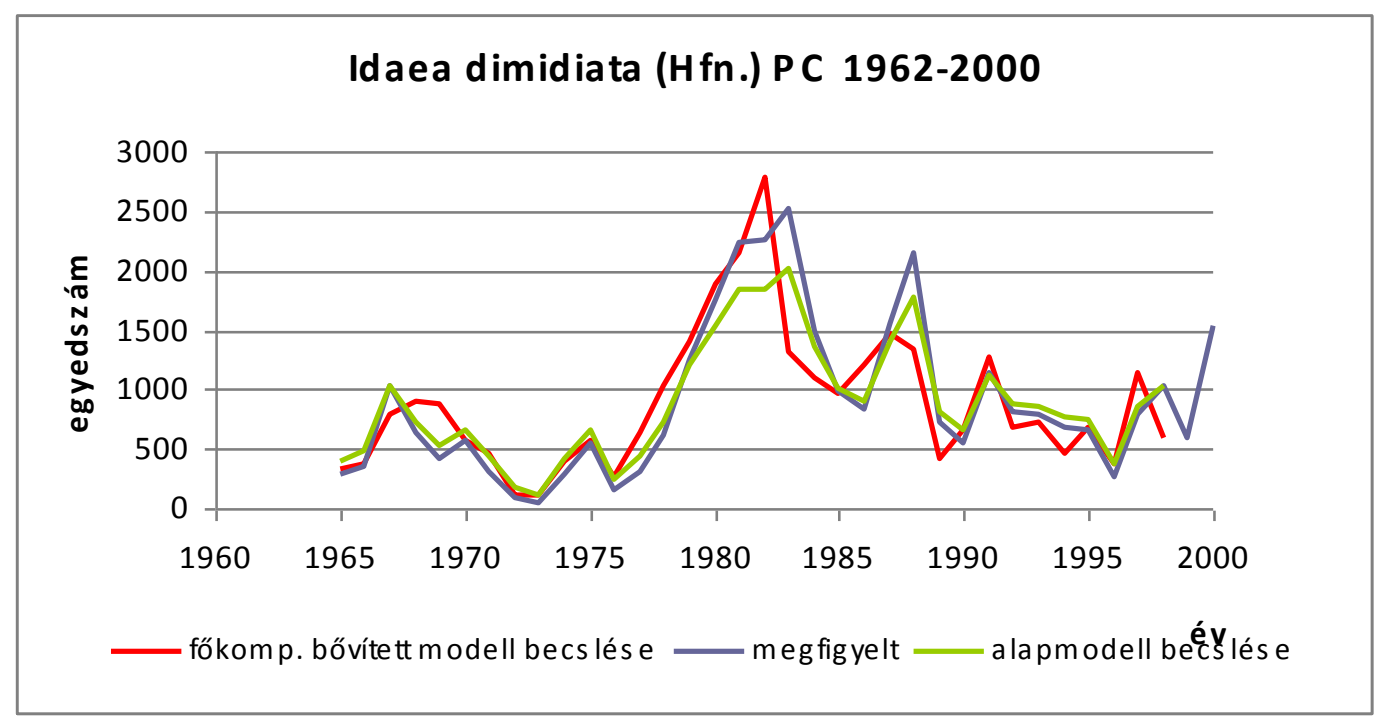

26. ábra Az Idaea dimidiata megfigyelt adataiból számított egyedszám, valamint az alap-és a fökomponensekkel bövitett modell becslése (forrás: a szerzö saját szerkesztése)

\section{$\underline{\text { Scopula nigropunctata }}$}

A S. nigropunctata esetében a PCA analízissel 11 fökomponenst képeztünk, melyekből egy, a PC8 főkomponenssel (együtthatója: -0,162) való kibővítés eredményezett a Bayes-féle Akaike információs kritériumra minimális értéket $\left(\mathrm{AIC}_{\mathrm{B}}=-27,809\right)$.

A modellbe bevett főkomponens loadingjai alapján a következő indikátorokkal van magas korrelációban:

\section{PC8}

$\rightarrow$ RAIN6: vizsgált év 6. dekádjának napi csapadékmennyiségének átlaga

$\rightarrow$ ETMIN18: előző év 18. dekádjának napi minimumhőmérsékleteinek átlaga

$\rightarrow$ ETMIN32: előző év 32. dekádjának napi minimumhőmérsékleteinek átlaga

$\rightarrow$ ETMINN25: előző év 25. dekádjának napi minimumhőmérsékleteinek minimuma

A 27. ábra mutatja a megfigyelt, valamint az alap- és a főkomponenssel bővített modell által becsült egyedszámokat. Az alapmodell és a főkomponenssel bővített modell korrelációs együtthatója is szignifikáns $\left(R_{a}=0,695 ; \mathrm{p}<0,001 ;\right.$ illetve $\left.R_{f b}=0,744 ; \mathrm{p}<0,001\right)$. A klímaindikátorokkal bővített modell eltartó kapacitása alacsonyabb, viszont a maximális szaporodási ráta értéke magasabb az alapmodell értékeihez viszonyítva. A sebességi tényező változása oly csekély, hogy az elhanyagolható. A modellek becsléseinek hibatagjai hasonlóak (40. táblázat). 
40. táblázat. A Scopula nigropunctata fajra vonatkozó alapmodell és a fókomponenssel bővitett modell föbb paraméterei (1962-2000)

\begin{tabular}{|l|c|c|}
\hline & alapmodell & fökomponenssel bővített modell \\
\hline Eltartó kapacitás $(K)$ & 716,8183 & 672,1275 \\
\hline sebességi tényező $(\theta)$ & 0,0008 & 0,0008 \\
\hline maximális szaporodási ráta $\left(R_{\max }\right)$ & 542,6733 & 609,9903 \\
\hline AIC $\mathrm{B}$ & $-27,3979$ & $-27,8093$ \\
\hline korrelációs együttható $(R)$ & 0,6947 & 0,7412 \\
\hline a becslés hibája $(R M S E)$ & 0,4173 & 0,3874 \\
\hline
\end{tabular}

Az alapmodell e fajnál is elég jól illeszkedik, így a főkomponenssel bővített modell csak csekély mértékben volt jobb, a magas kiugró értékeket mindkét modell alulbecsülte.

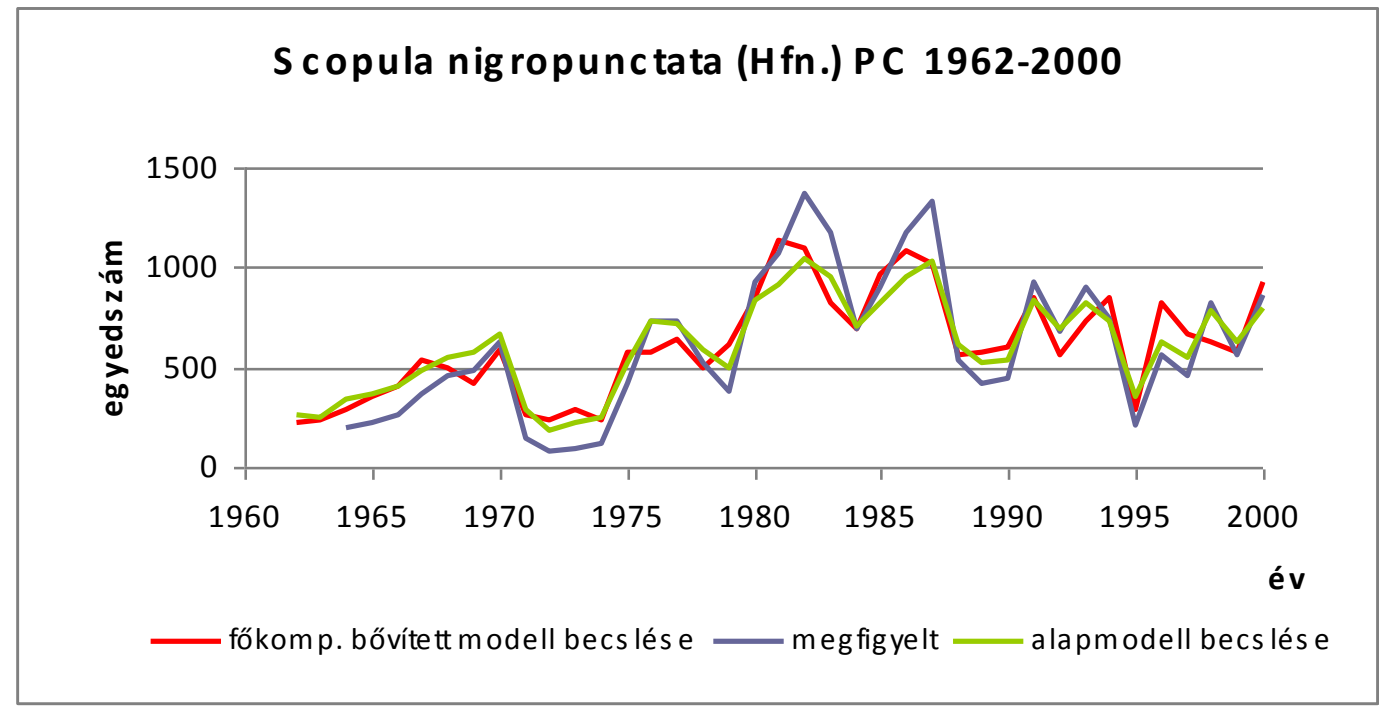

27. ábra A Scopula nigropunctata megfigyelt adataiból számított egyedszám, valamint az alap- és a fókomponenssel bövitett modell becslése (forrás: a szerzö saját szerkesztése)

\section{Pelurga comitata}

A $P$. comitata esetében az indikátorok lineáris kombinációjával 11 fökomponenst alkottunk, ezek közül három főkomponens együttes bevonásával kaptuk a Bayes-féle Akaike információs kritérium szerinti legkedvezőbb modellt ( $\left.\mathrm{AIC}_{\mathrm{B}}=-19,76\right)$, melynek főkomponenseinek együtthatói: -0,177 (PC1), -0,188 (PC8), -0,136 (PC10).

A modellbe bevett fökomponensek loadingjaik alapján a következő indikátorokkal vannak magas korrelációban:

\section{PC1:}

$\rightarrow$ ERAIN3: előző év 3. dekádjának napi csapadékmennyiségének átlaga

$\rightarrow$ ERAIN20: előző év 20. dekádjának napi csapadékmennyiségének átlaga

$\rightarrow$ MTATL4: vizsgált év negyedik hónapjának napi középhőmérsékleteinek átlaga

$\rightarrow$ TMIN11: vizsgált év 11. dekádjának napi minimumhőmérsékleteinek átlaga 
$\rightarrow$ TMIN12: vizsgált év 12. dekádjának napi minimumhőmérsékleteinek átlaga

$\rightarrow$ ETMAXX23: előző év 23. dekádjának napi maximumhőmérsékleteinek maximuma

$\rightarrow$ TMINN8: vizsgált év 8. dekádjának napi minimumhőmérsékleteinek minimuma

$\rightarrow$ ETMINN21: előző év 21. dekádjának napi minimumhőmérsékleteinek minimuma

\section{PC8:}

$\rightarrow$ MRAIN4: vizsgált év negyedik hónapjának napi csapadékmennyiségének átlaga

$\rightarrow$ ERAIN24: előző év 24. dekádjának napi csapadékmennyiségének átlaga

$\rightarrow$ ETMAXX23: előző év 23. dekádjának napi maximumhőmérsékleteinek maximuma

$\rightarrow$ TMAXX31: vizsgált év 31. dekádjának napi maximumhőmérsékleteinek maximuma

$\rightarrow$ TMINN8: vizsgált év 8. dekádjának napi minimumhőmérsékleteinek minimuma

$\rightarrow$ TMINN11: vizsgált év 11. dekádjának napi minimumhőmérsékleteinek minimuma

\section{PC10:}

$\rightarrow$ ETMIN11: előző év 11. dekádjának napi minimumhőmérsékleteinek átlaga

$\rightarrow$ ETMAXX23: előző év 23. dekádjának napi maximumhőmérsékleteinek maximuma

$\rightarrow$ ETMINN1: vizsgált év 1. dekádjának napi minimumhőmérsékleteinek minimuma

$\rightarrow$ ETMINN21: előző év 21. dekádjának napi minimumhőmérsékleteinek minimuma

A 28. ábra mutatja a megfigyelt, valamint az alap- és a főkomponenssel bővített modell által becsült egyedszámokat. Az alapmodell és a főkomponenssel bővített modell korrelációs együtthatója is szignifikáns $\left(R_{a}=0,513 ; \mathrm{p}<0,001 ;\right.$ illetve $\left.R_{f b}=0,729 ; \mathrm{p}<0,001\right)$. A klímaindikátorokkal bővített modell eltartó kapacitása alacsonyabb, viszont a maximális szaporodási ráta értéke magasabb az alapmodell értékeihez viszonyítva. A sebességi tényező változása oly csekély, hogy az elhanyagolható. A modell becslésének hibatagjának értéke alacsonyabb, ami pontosabb modellt jelent (41. táblázat).

41. táblázat. A Pelurga comitata fajra vonatkozó alapmodell és a fökomponensekkel bövített modell föbb paraméterei (1962-2000)

\begin{tabular}{|l|c|c|}
\hline & alapmodell & fökomponenssel bövített modell \\
\hline eltartó kapacitás $(K)$ & 831,3328 & 809,2788 \\
\hline sebességi tényezö $(\theta)$ & 0,0004 & 0,0004 \\
\hline maximális szaporodási ráta $\left(R_{\max }\right)$ & 1468,2662 & 1669,0229 \\
\hline AIC $_{\mathrm{B}}$ & $-18,8419$ & $-19,7608$ \\
\hline korrelációs együttható $(R)$ & 0,5128 & 0,7294 \\
\hline a becslés hibája $(R M S E)$ & 0,5197 & 0,4141 \\
\hline
\end{tabular}




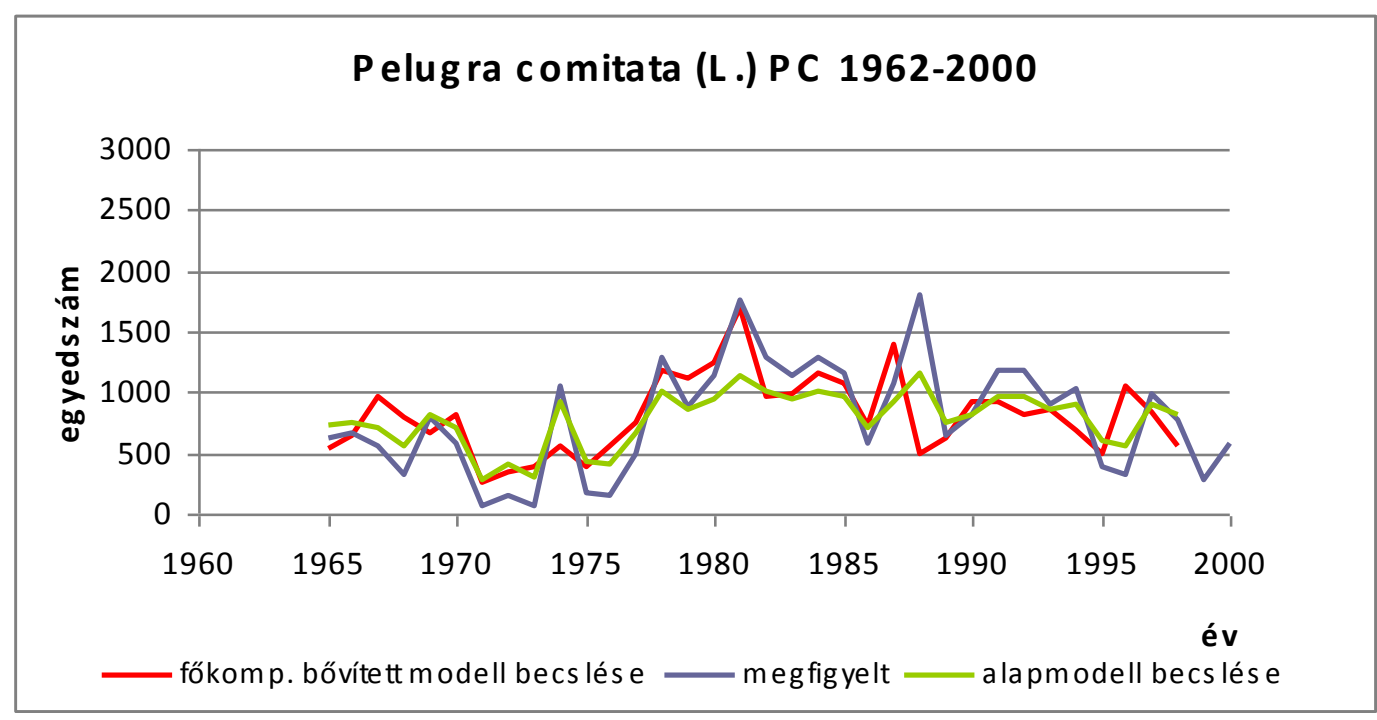

28. ábra A Pelurga comitata megfigyelt adataiból számított egyedszám, valamint az alap- és a fökomponenssel bövitett modell becslése (forrás: a szerzö saját szerkesztése)

\section{Eulithis pyraliata}

Az E. pyraliata esetében a PCA elemzés során 12 fökomponenst állítottunk elő. A modell bővítése során az Akaike kritérium $(-24,326)$ és a becslés hibájának figyelembe vételével, egy 3 fökomponenssel bővített modellt alkalmaztunk $(\mathrm{R}=0,887$; $\mathrm{p}<0,001)$ (42. táblázat).

A modellbe bevett fökomponensek loadingjaik alapján a következő indikátorokkal vannak magas korrelációban:

\section{PC1:}

$\rightarrow$ TMIN32: vizsgált év 32. dekádjának napi minimumhőmérsékleteinek átlaga

$\rightarrow$ TMAXX12: vizsgált év 12. dekádjának napi maximumhőmérsékleteinek maximuma

$\rightarrow$ TMAXX15: vizsgált év 15. dekádjának napi maximumhőmérsékleteinek maximuma

$\rightarrow$ TMAXX27: vizsgált év 27. dekádjának napi maximumhőmérsékleteinek maximuma

$\rightarrow$ ETMAXX12: előző év 12. dekádjának napi maximumhőmérsékleteinek maximuma

$\rightarrow$ MTMIN4: vizsgált év 4. hónapjának napi minimumhőmérsékleteinek átlaga

\section{PC8:}

$\rightarrow$ TMAX37: vizsgált év 37. dekádjának napi maximumhőmérsékleteinek átlaga

$\rightarrow$ ERAIN3: előző év 3. dekádjának napi csapadékmennyiségének átlaga

$\rightarrow$ MRAIN4: vizsgált év 4. hónapjának napi csapadékmennyiségének átlaga

$\rightarrow$ MTMIN4: vizsgált év 4. hónapjának napi minimumhőmérsékleteinek átlaga

\section{PC10:}

$\rightarrow$ RAIN35: vizsgált év 35. dekádjának napi csapadékmennyiségének átlaga

$\rightarrow$ ERAIN34: előző év 34. dekádjának napi csapadékmennyiségének átlaga

$\rightarrow$ TMINN25: vizsgált év 25. dekádjának napi minimumhőmérsékleteinek minimuma 
$\rightarrow$ MRAIN4: vizsgált év 4. hónapjának napi csapadékmennyiségének átlaga

42. táblázat $\mathrm{A}$ legalacsonyabb $\mathrm{AIC}_{\mathrm{B}}$ értékkel definiált legjobb modell együtthatói

\begin{tabular}{|c|c|c|}
\hline PC1 & PC8 & PC10 \\
\hline$-0,096$ & $-0,142$ & 0,101 \\
\hline
\end{tabular}

A 29. ábra mutatja a megfigyelt, valamint az alap- és a fökomponenssel bővített modell által becsült egyedszámokat. Az alapmodell és a főkomponenssel bővített modell korrelációs együtthatója is szignifikáns $\left(R_{a}=0,804 ; \mathrm{p}<0,001 ;\right.$ illetve $\left.R_{f b}=0,887 ; \mathrm{p}<0,001\right)$. A klímaindikátorokkal bővített modell eltartó kapacitása alacsonyabb, viszont a maximális szaporodási ráta értéke magasabb az alapmodell értékeihez viszonyítva. A sebességi tényező változása oly csekély, hogy az elhanyagolható. A modell becslésének hibatagjának értéke alacsonyabb, ami pontosabb modellt jelent (43. táblázat).

43. táblázat. Az Eulithis pyraliata fajra vonatkozó alapmodell és a fökomponensekkel bövitett modell föbb paraméterei (1962-2000)

\begin{tabular}{|l|c|c|}
\hline & alapmodell & fökomponenssel bövített modell \\
\hline eltartó kapacitás $(K)$ & 1240,8098 & 1129,0057 \\
\hline sebességi tényezö $(\theta)$ & 0,0007 & 0,0007 \\
\hline maximális szaporodási ráta $\left(R_{\max }\right)$ & 329,9609 & 454,8332 \\
\hline AIC ${ }_{\mathrm{B}}$ & $-20,4800$ & $-24,3264$ \\
\hline korrelációs együttható $(R)$ & 0,8027 & 0,8867 \\
\hline a becslés hibája $(R M S E)$ & 0,5064 & 0,3937 \\
\hline
\end{tabular}

Itt is megfigyelhető a bővített modell jobb illeszkedése és pontosabb becslése. Meg kell jegyeznem azonban, hogy ennél a fajnál az indikátorokkal bővített modell sokkal jobban illeszkedett, mint a fökomponensekkel bővített modell.

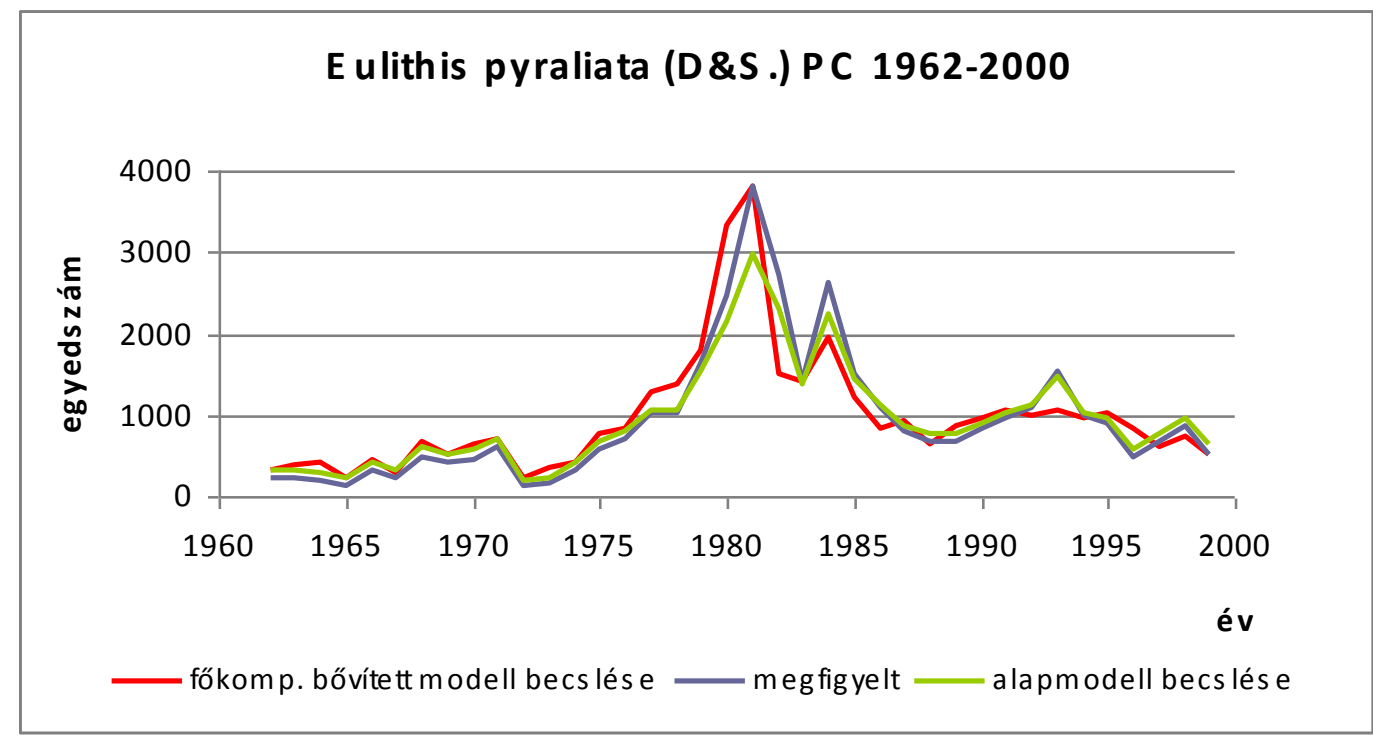

29. ábra Az Eulithis pyraliata megfigyelt adataiból számított egyedszám, valamint az alap- és a fökomponenssel bövített modell becslése (forrás: a szerzö saját szerkesztése) 
Összefoglalva elmondható, hogy a megfigyelt közel 40 éves intervallumra (1962-2000) alkotott modelljeink becslései jónak bizonyultak. A lepkék egyedszáma, illetve annak változása és a különböző klímaindikátorok közötti szignifikáns lineáris kapcsolat alapján az indikátorok vagy azok lineáris kombinációjaként előállított főkomponensek jelentősen javítani tudták az alapmodellt:

- Operophtera brumata esetében az alapmodellt javította a rajzást megelőző év március közepének napi maximumhőmérsékletének maximuma.

- Erannis defoliaria esetében az egyedszám jobb becsléséhez az alapmodellt a rajzást megelőző év februári és márciusi csapadékkal; a december második felének legmagasabb hőmérsékletével, valamint a vizsgált év április közepi átlaghőmérsékletével és áprilisi legalacsonyabb hőmérsékletével, valamint augusztus legmagasabb hőmérsékletével és az október végi-november eleji és december második felének csapadék értékeivel egészítettük ki.

- Colotois pennaria esetében a modellt bővítette a rajzást megelőző év februári csapadéka; április legmagasabb hőmérséklete; az augusztus közepi csapadék; az október véginovember eleji maximumhőmérséklet; a novemberi minimumhőmérséklet; a november végi-december eleji átlaghőmérséklet; a decemberi legalacsonyabb és a december második felének legmagasabb hőmérséklete, valamint a vizsgált év április közepi maximumhőmérséklete; az augusztusi csapadék; november közepének minimumhőmérséklete és a november végi-december eleji maximumhőmérséklet.

- Erannis aurantiaria esetében a rajzás évének október végi és novemberi csapadék értékével javítottuk az alapmodellt.

Az alábbi 4 fajjal kapcsolatban a magyar szakirodalomban semmilyen érdemleges irodalom sincs, amely a klimatikus tényezőkkel, illetve a fajokra gyakorolt hatásával foglalkozna.

- Idaea dimidiata esetében az egyedszám becslését javította a rajzást megelőző év január elejének leghidegebb hőmérséklete; a február eleji, április közepi és június végi minimumhőmérséklet; a szeptember közepi csapadék; az október végi-november eleji maximumhőmérséklet, valamint a vizsgált év március havának csapadék értéke. 
- Scopula nigropunctata esetében az alapmodellt a rajzást megelőző év június végi és november közepi minmumhőmérséklettel; az augusztus végi-szeptember eleji legalacsonyabb hőmérséklettel, valamint a vizsgált év február végi csapadék értékeivel bővítettük.

- Pelurga comitata esetében az egyedszám becslését a rajzást megelőző év január utolsó hetének csapadékával; az április közepi minimumhőmérséklettel; július végének legalacsonyabb hőmérsékletével; az augusztus közepi legmagasabb hőmérséklettel; az augusztus végi csapadékkal; a december közepi minimumhőmérséklettel, valamint a vizsgált év január eleji, március és április közepi legalacsonyabb hőmérsékletével; az április utolsó 3 hetének minimumhőmérsékleteivel; az áprilisi átlaghőmérséklettel és csapadékkal (azaz áprilisi átlag-, minimum-, legalacsonyabb hömérséklet és csapadék indikátorokkal); az október végi november eleji legmagasabb hőmérséklettel javítottuk.

- Eulithis pyraliata esetében az alapmodellt a rajzást megelőző év január végi, március közepi, november végi-december eleji csapadékával; az április végi legmagasabb hőmérséklettel; valamint a vizsgált év áprilisi minimumhőmérsékletével és csapadékával; az április végi, június eleji, szeptember második felében lévő legmagasabb hőmérséklettel; az augusztus végi-szeptember eleji legalacsonyabb hőmérséklettel; a november közepi minimumhőmérséklettel; a december közepi csapadék és a december végi maximumhőmérséklettel bővítettük.

Az időjárási ténezők hatásának összefoglalását a 13. melléklet tartalmazza.

\subsection{A klimatikus indikátoroknak a RegCM3.1 regionális klímamodell becslései alapján előállított értékei és a lepkék megfigyelt és a modellek által becsült egyedszámainak összevetése}

Az OMSz megfigyelt értékei alapján elöállított indikátorok értékeit a RegCM3.1 regionális klímamodell becslései alapján is kiszámoltuk. Arra voltunk kíváncsiak, hogy milyen változást jelez a modell az 1961-1990-es időszakhoz képest a 2021-2050-es és a 2071-2100-as időszakokra. Az indikátor- és főkomponens-analízisben kapott faktorok értékeit a RegCM3.1 regionális klímamodell 1961-1990-es, a 2021-2050-es és a 2071-2100-as időszeletekre 
prognosztizált eredményeivel is kiszámoltuk, és becsültük a várható egyedszámot, illetve eloszlásának várható változását.

Az 1962-2000 időszakban megfigyelt, az 1961-1990-es időszeletre becsült, valamint a jövőben várható klímaindikátor értékek 2021-2050-es és a 2071-2100-as idősorokra vett átlagértékeit találhatjuk a 44. táblázatban.

44. táblázat A fajok klímaindikátorainak átlagai az 1962-2000-es megfigyelt időszakra, illetve a RegCM3.1 regionális klimamodell 1961-1990-es, 2021-2050-es és a 2071-2100-as becsült adataiból számítva az idösorok páronkénti összehasonlításával

\begin{tabular}{|c|c|c|c|c|}
\hline Klimatikus indikátorok & $\begin{array}{l}\text { 1962-2000 } \\
\text { Átlag }\end{array}$ & $\begin{array}{l}\text { 1961-1990 } \\
\text { Átlag }\end{array}$ & $\begin{array}{l}\text { 2021-2050 } \\
\text { Átlag }\end{array}$ & $\begin{array}{c}\text { 2071-2100 } \\
\text { Átlag }\end{array}$ \\
\hline \multicolumn{5}{|l|}{ Operophtera brumata } \\
\hline ETMAXX8 & $15,19 \mathrm{ab}$ & $13,67 \mathrm{a}$ & $14,57 \mathrm{a}$ & $17,24 \mathrm{~b}$ \\
\hline \multicolumn{5}{|l|}{ Erannis defoliaria } \\
\hline MTMINN10 & $0,93 \mathrm{~b}$ & $-0,63 \mathrm{a}$ & $1,03 \mathrm{~b}$ & $5,61 \mathrm{c}$ \\
\hline \multicolumn{5}{|l|}{ Colotois pennaria } \\
\hline RAIN31 & $1,23 \mathrm{a}$ & $2,79 \mathrm{~b}$ & $1,95 \mathrm{ab}$ & $2,46 \mathrm{~b}$ \\
\hline ETMAXX36 & $8,23 \mathrm{a}$ & $8,98 \mathrm{a}$ & $9,68 \mathrm{a}$ & $11,60 \mathrm{~b}$ \\
\hline EMRAIN2 & $1,19 \mathrm{a}$ & $1,81 \mathrm{bc}$ & $1,61 \mathrm{ab}$ & $2,22 \mathrm{c}$ \\
\hline \multicolumn{5}{|l|}{ Erannis aurantiaria } \\
\hline MRAIN11 & $1,81 \mathrm{a}$ & $2,47 \mathrm{~b}$ & $1,96 \mathrm{ab}$ & $2,31 \mathrm{~b}$ \\
\hline \multicolumn{5}{|l|}{ Idaea dimidiata } \\
\hline RAIN9 & $1,13 \mathrm{a}$ & $2,32 \mathrm{c}$ & $1,31 \mathrm{ab}$ & $1,96 \mathrm{~b} \mathrm{c}$ \\
\hline ETMIN18 & $15,79 \mathrm{~b}$ & $13,45 \mathrm{a}$ & $14,06 \mathrm{a}$ & $16,42 \mathrm{c}$ \\
\hline ETMINN1 & $-6,66$ a & $-5,08 \mathrm{ab}$ & $-4,46 b$ & $-1,91 \mathrm{c}$ \\
\hline \multicolumn{5}{|l|}{ Scopula nigropunctata } \\
\hline ETMIN32 & $4,04 \mathrm{a}$ & $3,45 \mathrm{a}$ & $3,39 \mathrm{a}$ & $6,03 \mathrm{~b}$ \\
\hline \multicolumn{5}{|l|}{ Pelurga comitata } \\
\hline ETMIN11 & $6,62 \mathrm{~b}$ & $5,33 \mathrm{a}$ & $7,33 \mathrm{bc}$ & $7,89 \mathrm{c}$ \\
\hline MRAIN4 & $1,43 \mathrm{a}$ & $2,10 \mathrm{~b}$ & $1,88 \mathrm{ab}$ & $2,36 \mathrm{~b}$ \\
\hline \multicolumn{5}{|l|}{ Eulithis pyraliata } \\
\hline ERAIN34 & $1,81 \mathrm{a}$ & $1,36 \mathrm{a}$ & $1,87 \mathrm{a}$ & $2,71 \mathrm{a}$ \\
\hline ERAIN3 & $1,20 \mathrm{a}$ & $1,94 \mathrm{~b}$ & $1,77 \mathrm{ab}$ & $2,39 \mathrm{~b}$ \\
\hline ERAIN9 & $1,11 \mathrm{a}$ & $2,32 \mathrm{~b}$ & $1,35 \mathrm{a}$ & $1,86 \mathrm{ab}$ \\
\hline
\end{tabular}

Az a,b,c,d jelölések a különböző időszeletek várható értékeinek egymással történt t-próbával való összehasonlítás utáni szignifikáns eltérését mutatja a legkisebb értéktől kiindulva.

A vizsgált fajok egyedszám értékeinek számítását a RegCM3.1 regionális klímamodell becsléseire támaszkodva is elvégeztem. Arra kerestem a választ, hogy milyen változást prognosztizál a modell a 2021-2050-es és a 2071-2100-as időszakokra az összehasonlításokhoz használt 1961-1990-es referencia-időszakot figyelembe véve.

A fajoknak rögzített egyedszámmal induló modellek által becsült egyedszámát vizsgáltuk úgy, hogy ha minden év meteorológiai indikátorával, rögzített 10, 50, 100, . 5000, 7000, 9000, 10000 egyedszámmal indítva lefuttatjuk a klímaindikátorral és a főkomponenssel bővített modellt, akkor az mekkora egyedszámot fog becsülni a következő évre, vagyis a különböző évek meteorológiai adatai milyen egyedszám- növekedést, vagy csökkenést eredményezhetnek. Tehát 
egy rögzített egyedszámmal mind a 30 évre vonatkozó indikátorokkal futtattuk a modelleket, így egy-egy rögzített egyedszámra 30-30 egyedszámot kaptunk. ez a 30-30 egyedszám érték arra ad választ, hogy HA ekkora egyedszám van egy évben ÉS ilyenek az időjárási viszonyok, AKKOR milyen egyedszám várható egy év elteltével. Így az egy éves várható egyedszámváltozásra rögzített induló egyedszám mellett számolhatunk minimumot (legkedvezőtlenebb forgatókönyv a rovar számára), maximumot (legkedvezőbb forgatókönyv), átlagot, mediánt, szórást. Amennyiben egy adott induló egyedszámnál magasabb egyedszámot kapunk a következő évre, az a populáció szaporodását, ha kevesebbet, az a populáció megfogyatkozását jelenti adott időjárási viszonyok mellett. Az induló egyedszámmal megegyező számú következő évi populáció az állomány stagnálását fejezi ki, ezt a 31-34. ábráktól kezdődően fekete vonallal jelöltük (identitás függvény). Az induló egyedszámok függvényáben így ábrázolni tudjuk a populáció várható növekedését, fogyatkozását, illetve stagnálását az időszakra becsült várható időjárási viszonyok mellett.

A megfigyelt és a jövőre, valamint a referencia időszakra (az előbbiekben leírt időszeletekre) vonatkozó becsült egyedszámok minimumainak, maximumainak, mediánjainak, szórásainak és átlagainak átlagértékeit klímaindikátorok és a főkomponensek tükrében a 45-46. táblázatban találjuk. 
45. táblázat A fajoknak a rögzített egyedszámmal induló klímaindikátorokkal bövített modellek által becsült egyedszámának statisztikai eredményei (minimum, maximum, medián, szórás, átlag) az 1962-2000-es megfigyelt idöszakra, illetve a RegCM3.1 regionális klimamodell 1961-1990-es, 2021-2050-es és a 2071-2100-as becsült adataiból számítva az idösorok páronkénti összehasonlításával

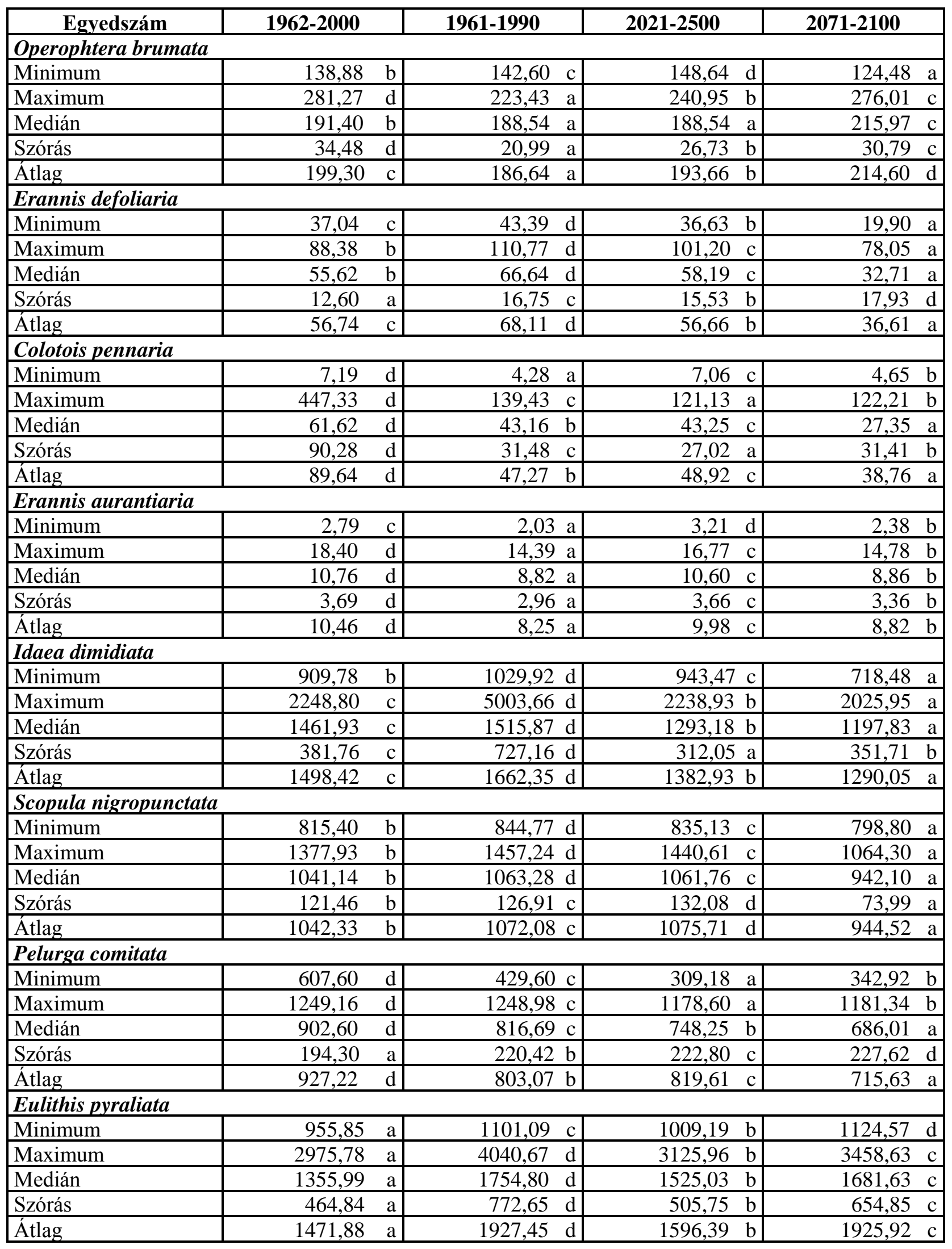


46. táblázat $A$ fajoknak a rögzített egyedszámmal induló fökomponensekkel bövített modellek által becsült egyedszámának statisztikai eredményei (minimum, maximum, medián, szórás, átlag) az 1962-2000-es megfigyelt idöszakra, illetve a RegCM3.1 regionális klímamodell 1961-1990-es, 2021-2050-es és a 2071-2100-as becsült adataiból számítva az idösorok páronkénti összehasonlításával

\begin{tabular}{|c|c|c|c|c|}
\hline Egyedszám & 1962-2000 & $1961-1990$ & $2021-2500$ & 2071-2100 \\
\hline \multicolumn{5}{|c|}{ Operophtera brumata PC } \\
\hline Minimum & $112,90 \mathrm{~b}$ & $121,61 \mathrm{c}$ & $138,26 \mathrm{~d}$ & $97,09 \mathrm{a}$ \\
\hline Maximum & $303,12 \mathrm{~d}$ & $285,31 \mathrm{~b}$ & $294,79 \mathrm{c}$ & $279,62 \mathrm{a}$ \\
\hline Medián & $197,42 \mathrm{~b}$ & $199,32 \mathrm{c}$ & $187,20 \mathrm{a}$ & $210,34 \mathrm{~d}$ \\
\hline Szórás & $47,90 \mathrm{~d}$ & $44,57 \mathrm{c}$ & $44,21 \mathrm{~b}$ & $42,83 \mathrm{a}$ \\
\hline Átlag & $202,94 \mathrm{~d}$ & $202,15 \mathrm{c}$ & $201,70 \mathrm{a}$ & $202,13 \mathrm{~b}$ \\
\hline \multicolumn{5}{|c|}{ Erannis defoliaria $\quad P C$} \\
\hline Minimum & $27,05 \mathrm{c}$ & $26,12 \mathrm{~b}$ & $24,09 \mathrm{a}$ & $30,01 \mathrm{~d}$ \\
\hline Maximum & $95,90 \mathrm{~d}$ & $86,78 \mathrm{c}$ & $67,90 \mathrm{a}$ & $68,06 \mathrm{~b}$ \\
\hline Medián & $50,15 \mathrm{~d}$ & $46,74 \mathrm{a}$ & $47,43 \mathrm{~b}$ & $47,80 \mathrm{c}$ \\
\hline Szórás & $15,49 \mathrm{~d}$ & $13,76 \mathrm{c}$ & $10,33 \mathrm{~b}$ & $8,20 \mathrm{a}$ \\
\hline Átlag & $50,14 \mathrm{~d}$ & $49,70 \mathrm{c}$ & $49,03 \mathrm{~b}$ & $48,59 \mathrm{a}$ \\
\hline \multicolumn{5}{|c|}{ Colotois pennaria $\quad P C$} \\
\hline Minimum & $3,84 \mathrm{a}$ & $6,50 \mathrm{c}$ & $7,20 \mathrm{~d}$ & $4,07 \mathrm{~b}$ \\
\hline Maximum & $107,76 \mathrm{c}$ & $112,72 \mathrm{~d}$ & $52,06 \mathrm{a}$ & $56,87 \mathrm{~b}$ \\
\hline Medián & $18,32 \mathrm{~d}$ & $15,62 \mathrm{~b}$ & $14,56 \mathrm{a}$ & $15,80 \mathrm{c}$ \\
\hline Szórás & $23,06 \mathrm{~d}$ & $19,74 \mathrm{c}$ & $11,83 \mathrm{a}$ & $13,74 \mathrm{~b}$ \\
\hline Átlag & $23,34 \mathrm{~d}$ & $21,00 \mathrm{c}$ & $19,73 \mathrm{a}$ & $20,48 \mathrm{~b}$ \\
\hline \multicolumn{5}{|c|}{ Erannis aurantiaria $\quad P C$} \\
\hline Minimum & $2,79 \mathrm{~b}$ & $4,12 \mathrm{~d}$ & $3,71 \mathrm{c}$ & $1,33 \mathrm{a}$ \\
\hline Maximum & $18,40 \mathrm{~d}$ & $13,42 \mathrm{~b}$ & $14,06 \mathrm{c}$ & $8,96 \mathrm{a}$ \\
\hline Medián & $10,76 \mathrm{~d}$ & $9,17 \mathrm{~b}$ & $9,26 \mathrm{c}$ & 5,17 a \\
\hline Szórás & $3,69 \mathrm{~d}$ & $2,26 \mathrm{~b}$ & $2,50 \mathrm{c}$ & $2,10 a$ \\
\hline Átlag & $10,46 \mathrm{~d}$ & $9,22 \mathrm{c}$ & $9,16 \mathrm{~b}$ & $4,97 \mathrm{a}$ \\
\hline \multicolumn{5}{|c|}{ Idaea dimidiata $\quad P C$} \\
\hline Minimum & 734,81 a & $858,70 \mathrm{~d}$ & $836,87 \mathrm{c}$ & $836,50 \mathrm{~b}$ \\
\hline Maximum & $2296,17 \mathrm{~b}$ & $2558,22 \mathrm{~d}$ & $2184,76 \mathrm{a}$ & $2299,48 \mathrm{c}$ \\
\hline Medián & $1288,04 \mathrm{a}$ & $1360,73 \mathrm{~d}$ & $1303,79 \mathrm{~b}$ & $1338,57 \mathrm{c}$ \\
\hline Szórás & $401,55 \mathrm{~d}$ & 344,82 a & $356,76 \mathrm{~b}$ & $382,78 \mathrm{c}$ \\
\hline Átlag & $1387,19 \mathrm{~d}$ & $1370,04 \mathrm{a}$ & $1375,68 \mathrm{~b}$ & $1379,53 \mathrm{c}$ \\
\hline \multicolumn{5}{|c|}{ Scopula nigropunctata $P C$} \\
\hline Minimum & $774,87 \mathrm{~b}$ & $829,68 \mathrm{~d}$ & $781,33 \mathrm{c}$ & 753,98 a \\
\hline Maximum & $1384,72 \mathrm{c}$ & $1506,06 \mathrm{~d}$ & $1322,34 \quad \mathrm{a}$ & $1378,83 \mathrm{~b}$ \\
\hline Medián & $1010,71 \mathrm{a}$ & $1026,03 \mathrm{~b}$ & $1071,44 \mathrm{~d}$ & $1044,99 \mathrm{c}$ \\
\hline Szórás & $170,76 \mathrm{~d}$ & $145,79 \mathrm{c}$ & 113,89 a & $139,66 \mathrm{~b}$ \\
\hline Átlag & $1053,59 \mathrm{~d}$ & $1049,36 \mathrm{c}$ & 1046,52 a & $1049,11 \mathrm{~b}$ \\
\hline \multicolumn{5}{|c|}{ Pelurga comitata $\quad P C$} \\
\hline Minimum & $445,32 \mathrm{a}$ & $611,78 \mathrm{~b}$ & $632,14 \mathrm{c}$ & $666,02 \mathrm{~d}$ \\
\hline Maximum & $1876,51 \mathrm{~d}$ & $1761,76 \mathrm{c}$ & $1596,46 \mathrm{a}$ & $1602,09 \mathrm{~b}$ \\
\hline Medián & $1010,28 \mathrm{c}$ & 988,14 a & $1021,58 \mathrm{~d}$ & $1004,50 \mathrm{~b}$ \\
\hline Szórás & $295,45 \mathrm{~d}$ & $257,67 \mathrm{~b}$ & $217,41 \mathrm{a}$ & $266,47 \mathrm{c}$ \\
\hline Átlag & $1045,08 \mathrm{~d}$ & $1032,14 \mathrm{~b}$ & $1026,15 \mathrm{a}$ & $1036,25 \mathrm{c}$ \\
\hline Eulithis pyraliata & $P C$ & & & \\
\hline Minimum & $1092,39 \mathrm{~b}$ & $1147,91 \mathrm{~d}$ & $990,72 \mathrm{a}$ & $1103,62 \mathrm{c}$ \\
\hline Maximum & $2603,74 \mathrm{~d}$ & $1978,40 \mathrm{a}$ & $2098,48 \mathrm{~b}$ & $2100,10 \mathrm{c}$ \\
\hline Medián & $1553,54 \mathrm{~d}$ & $1517,19 \mathrm{~b}$ & $1489,41 \mathrm{a}$ & $1538,38 \mathrm{c}$ \\
\hline Szórás & $323,78 \mathrm{~d}$ & $201,83 \mathrm{a}$ & $241,64 \mathrm{c}$ & $223,91 \quad b$ \\
\hline Átlag & $1546,34 \mathrm{~d}$ & 1529,16 a & $1534,34 \mathrm{c}$ & $1531,27 \mathrm{~b}$ \\
\hline
\end{tabular}




\section{Operophtera brumata}

Az indikátorokkal bővített modellben az ETMAXX8 klimatikus indikátor jövőbeli változását figyelembe véve a faj egyedszámait becsültem. A modell a klimatikus indikátorunkban (azaz a rajzást megelőző év március közepi maximumhőmérsékletekben) bekövetkező értékének szignifikáns növekedését jelzi a 2071-2100-as időszeletre a t-próba alapján (30. ábra).

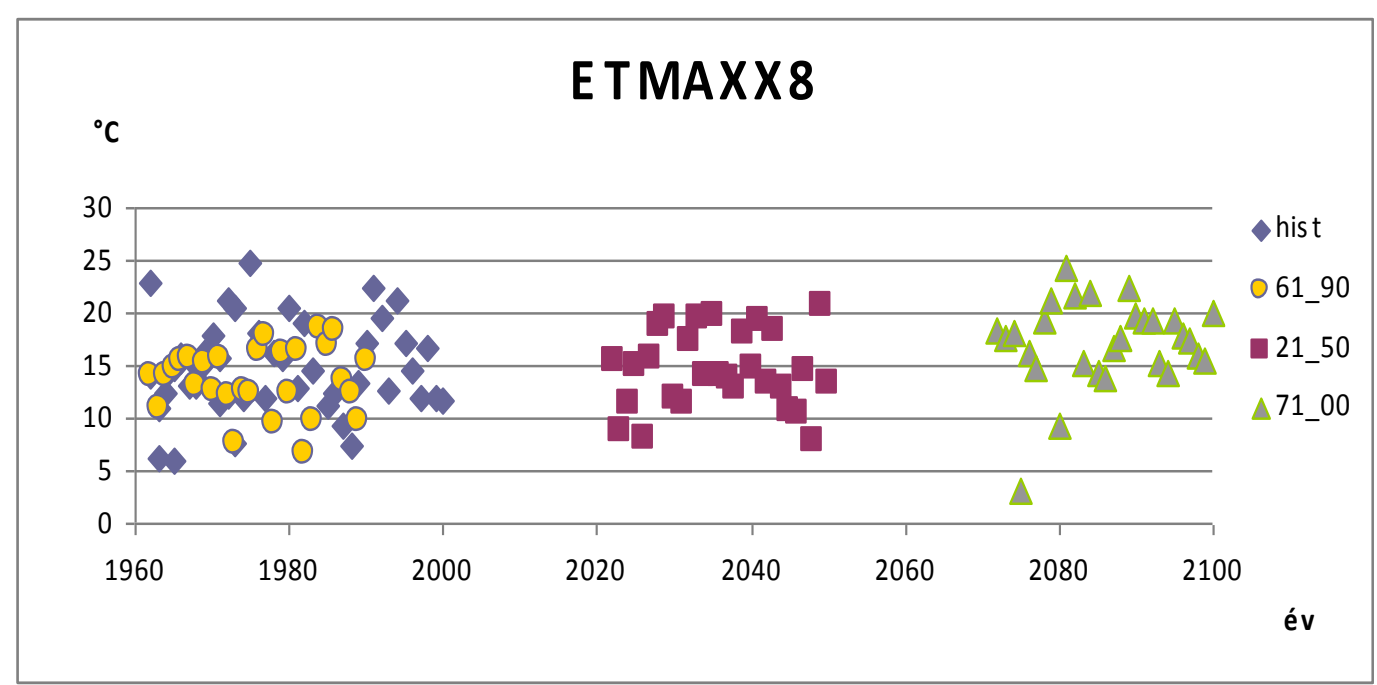

30. ábra Az ETMAXX8 indikátor értékei az 1962-2000-es megfigyelt idöszakra, illetve a RegCM3.1 regionális klímamodell 1961-1990-es, 2021-2050-es és a 2071-2100-as becsült adataiból számítva (forrás: a szerző saját szerkesztése)

Ha a becsült egyedszámok minimum értékeit vesszük figyelembe mindhárom RegCMszerinti időszeletre vonatkozóan, a következő eredményekre jutottam: a bővített modell becslései szignifikáns egyedszám-változást prognosztizálnak, miszerint rövidtávon a jövőben (2021-2050) az egyedszám-emelkedésére számíthatunk. Hosszútávon (2071-2100) azonban csökkenést (31. ábra, 43. táblázat) várhatunk az ETMAXX8 indikátornak a RegCM3.1 által becsült változása mellett.

Ugyanakkor, ha a modell egyedszám-becsléseinek maximum értékeinek becslését tekintjük, akkor a 2021-2050 intervallumra vetített becslések az 1961-1990-es referenciaidőszakhoz képest egyedszám-emelkedést, a 2071-2100-as időszakra vonatkozóan, pedig további szignifikáns emelkedést jeleznek (32. ábra, 43. táblázat). 

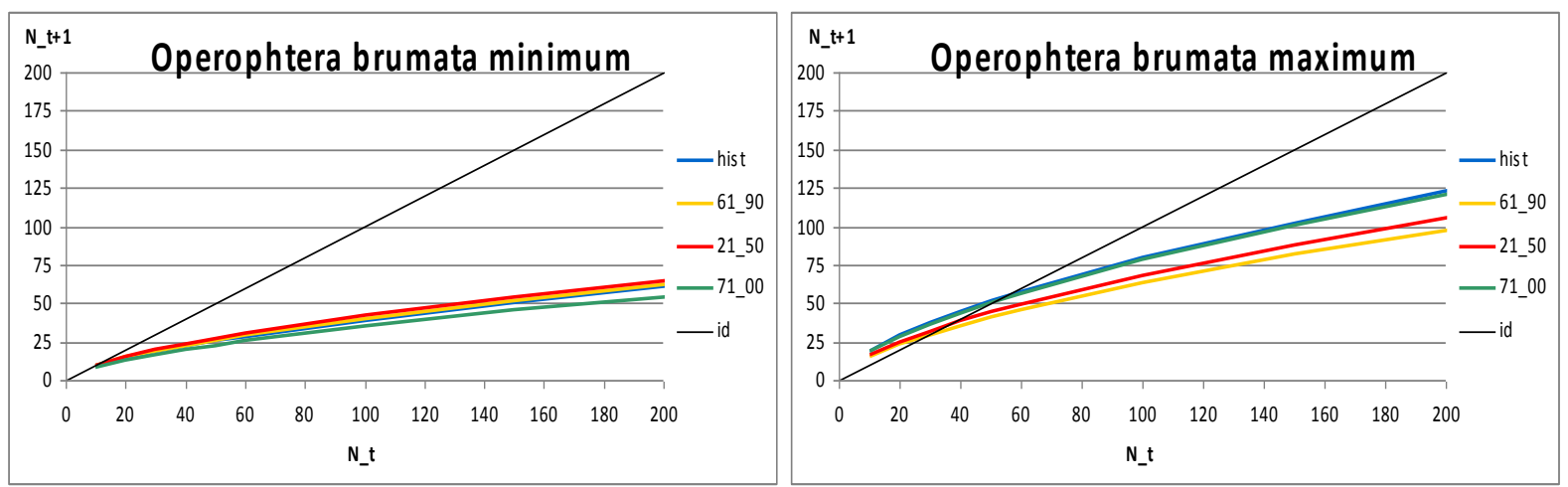

31-32. ábra $A z$ Operophtera brumata rögzített egyedszámmal induló indikátorral bővített modellek által becsült egyedszámának minimum és maximum értékeinek becslése az 1962-2000-es megfigyelt idöszakra, illetve a RegCM3.1 regionális klimamodell 1961-1990-es, 2021-2050-es és a 2071-2100-as idősorai (forrás: a szerző saját szerkesztése)

A főkomponenssel bővített modellel is becslést végeztük a RegCM3.1 regionális klímamodell 1961-1990-es, 2021-2050-es és a 2071-2100-as időszeleteire vetítve. A márciusi hőmérsékleti értékek, az áprilisi és augusztusi maximum hőmérséklet és az augusztusi csapadék jövőbeni alakulása szintén befolyásolhatja a faj egyedszámának alakulását. A faktorral bővített modell által becsült egyedszámok maximum értékeit vizsgálva, alacsony induló egyedszám esetén a következő évi egyedszám közel azonos vagy kis mértékben növekedni fog (33. ábra). Ha alacsony induló egyedszámmal számolunk $(10,20)$ akkor az egyedszám növekedése várható a jövőbeni két időszeletben, de a 2071-2100 között ez a növekedés mértéke kisebb. Ezen induló egyedszámok felett viszont már az induló egyedszámokhoz képest alacsonyabb egyedszám várható a következő évi rajzáskor (34. ábra).
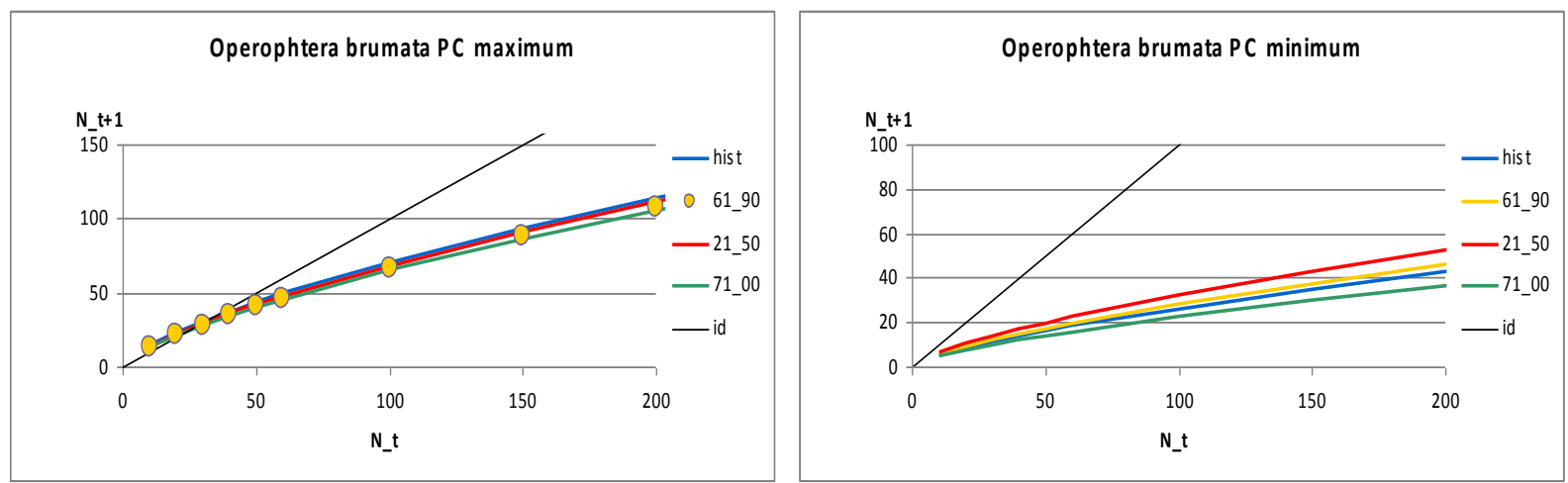

33-34. ábra Az Operophtera brumata rögzitett egyedszámmal induló fökomponenssel bövített modellek által becsült egyedszámának minimum és maximum értékeinek becslése az 1962-2000-es megfigyelt idöszakra, illetve a RegCM3.1 regionális klímamodell 1961-1990-es, 2021-2050-es és a 2071-2100-as idösorok páronkénti összehasonlitásával (forrás: a szerzö saját szerkesztése)

Az ábrán látható sárga pöttyök jelölik vonal helyett az 1961-1990-es időszelet eredményét a könnyebb áttekinthetőség érdekében.

Az identitás egyenes (fekete vonal) jelenti azt, amikor az iinduló egyedszám a következő évre nem változik. Ha az egyenes felett fut a görbe, az az induló egyedszámhoz képest egyedszám-növekedést, ha alatta, akkor egyedszám-csökkenést becsül. 


\section{Erannis defoliaria}

Az indikátorral bővített modell szerint a klimatikus indikátorok jövőbeli változását figyelembe véve a faj egyedszámának becsült minimum és maximum értékei is szignifikáns csökkenést vetítenek elöre mind a 2021-2050-es, mind pedig a 2071-2100-as időszeletre vonatkozóan.

A RegCM3.1 klímamodell az októberi hónapok minimum hőmérsékletére a 1961-1990es időszakra $-0,63^{\circ} \mathrm{C}$-ot becsül $\left.\mathrm{p}<0,001\right)$, a $2021-2050$-es időszakra $1,03{ }^{\circ} \mathrm{C}$-ot $(\mathrm{p}<0,001)$, a 2071-2100-as időszakra már 5,61 ${ }^{\circ} \mathrm{C}$-ot prognosztizál $(\mathrm{p}<0,001)$ (35. ábra). Eszerint az októberi hónapok minimum hőmérsékletének emelkedése várható. Mindez azt feltételezi, hogy az októbertől rajzó, és csak a hideg idő beálltával megjelenő lepkék később tudnak megjelenni, ami a következő évi egyedszám alakulására negatívan hat.

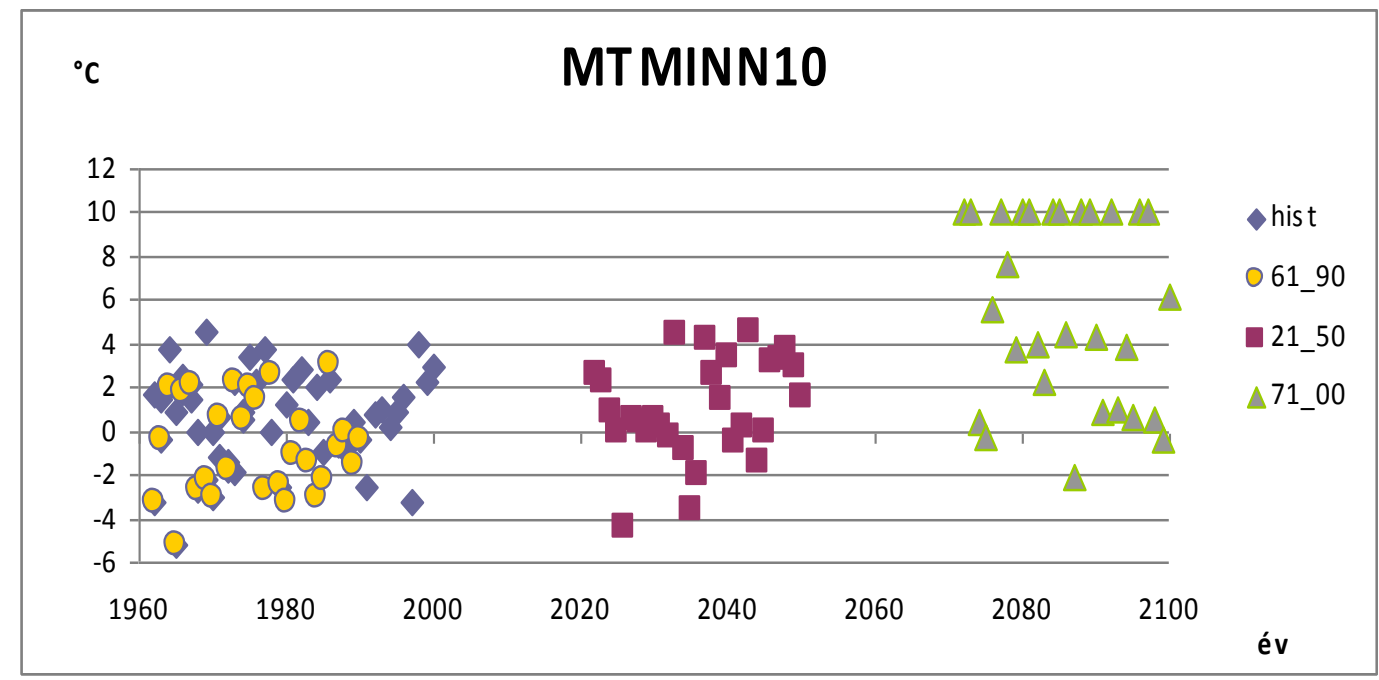

35. ábra Az MTMINN10 indikátor értékei az 1962-2000-es megfigyelt idöszakra, illetve a RegCM3.1 regionális klimamodell 1961-1990-es, 2021-2050-es és a 2071-2100-as becsült adataiból számítva (forrás: a szerzö saját szerkesztése)

Az időszeletek MTMINN10 értékei minden jövőbeli időszeletre vonatkozóan szignifikánsan emelkednek a referenciaidőszakhoz képest $(\mathrm{p}<0,05)$. A 35. ábrán láthatjuk a klimatikus indikátorunk értékének becsült növekedését, amelynek hatására a modell az egyedszámokra vonatkozóan az alábbi becslést adta:

A rögzített egyedszámmal induló modellek által becsült minimum egyedszám értékeit vizsgálva megállapítható, hogy nagyobb egyedszámból indulva a következő évben nagyobb mértékű egyedszám-csökkenés várható (36. ábra). A referencia időszak becsült 43,39 minimum átlag értékéről a 2021-2050-es időszakra a modell már csak 36,63 minimum átlag egyedszám értéket becsül, s további szignifikáns csökkenés várható a 2071-2100-es időszakra becsült 19,90 átlag minimumérték előrevetítésével. 
Ha az induló egyedszám alacsony (40 alatti), akkor a becsült maximum egyedszám növekedése várható a jövőben mindkét időszeletben. A referencia intervallum becslésében az induló egyedszám kb. 40-ig tartó növekedése, a következö évi egyedszám növekedését vonja magával, de kb. 40 induló egyedszám esetén, már következő évtől az induló egyedszámnál kevesebb egyedszámot valószínüsíthetünk. A 2021-2050 időszakra már kevesebb induló egyedszámnál (30) megállapítottam, hogy e induló egyedszám felett az egyedszám a következő évre lecsökken a induló egyedszám alá. Végül 2071-2100 közötti évekre megállapítottam, hogy csak alacsony induló egyedszám (10) esetén nőtt az egyedszám a következő évben, s az e feletti induló egyedszám esetén a következő évben az induló egyedszámnál alacsonyabb egyedszám várható.
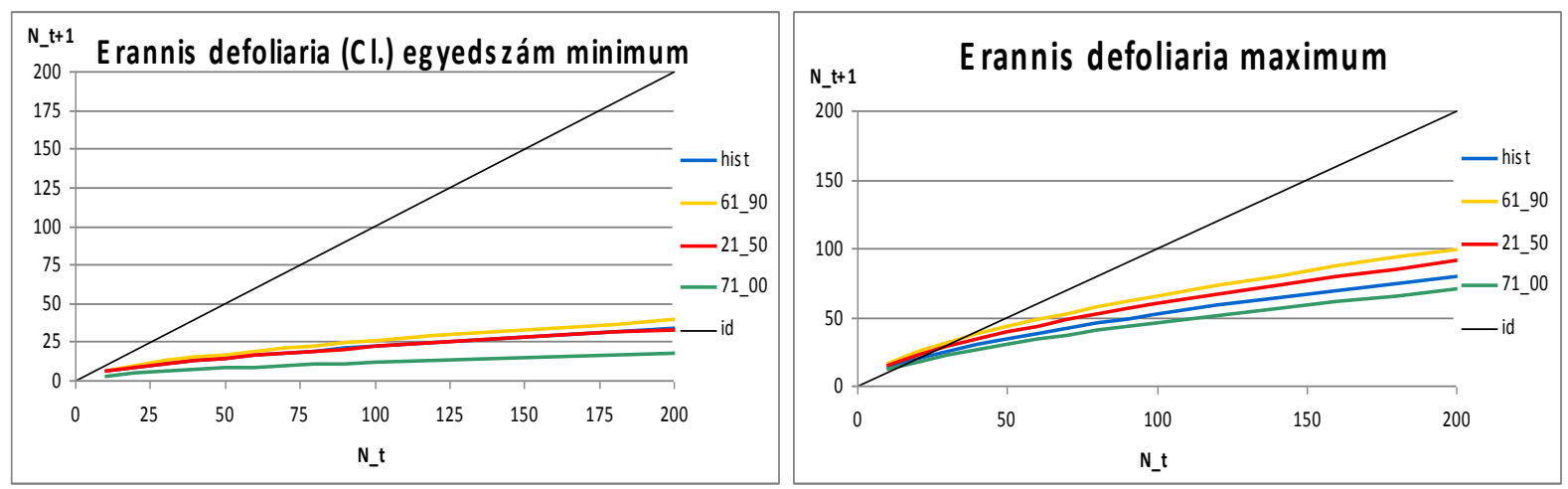

36-37. ábra Az Erannis defoliaria rögzített egyedszámmal induló indikátorral bövített modellek által becsült egyedszámának minimum és maximum értékeinek becslése az 1962-2000-es megfigyelt időszakra, illetve a RegCM3.1 regionális klimamodell 1961-1990-es, 2021-2050-es és a 2071-2100-as idösorai (forrás: a szerzö saját szerkesztése)

A főkomponenssel bővített modellel is elvégeztük a becsléseket 1961-1990-es időszakra, a 2021-2050-es és a 2071-2100-as időszakra vonatkoztatva. A főkomponenssel bővített modell becsült egyedszámainak minimum értékeit figyelembe véve, elmondhatjuk, hogy az induló egyedszámok nagyságától függetlenül minden esetben csökken az egyedszám az előző évi egyedszámhoz képest (38. ábra).

Ha az időszeletekre lebontva vizsgálódunk, a közeli jövőben (2021-2050) az egyedszám csökkenés mértékére nagyobb fokú csökkenést becsülünk, s ezt követően a 2071-2100 időintervallum minimum értékei a referencia időszakra becsült értékek fölé emelkedhetnek. A faktorral bővített modell által becsült egyedszámok maximum értékeit vizsgálva, az alacsony induló egyedszámmal számolva a következező évi egyedszám közel azonos lehet. Ennél magasabb induló egyedszámok esetén mind a 2021-2050-es és mind a 2071-2100-as időszeletben az egyedszám várhatóan kevesebb lesz az előző évi induló egyedszámnál (39. ábra). 

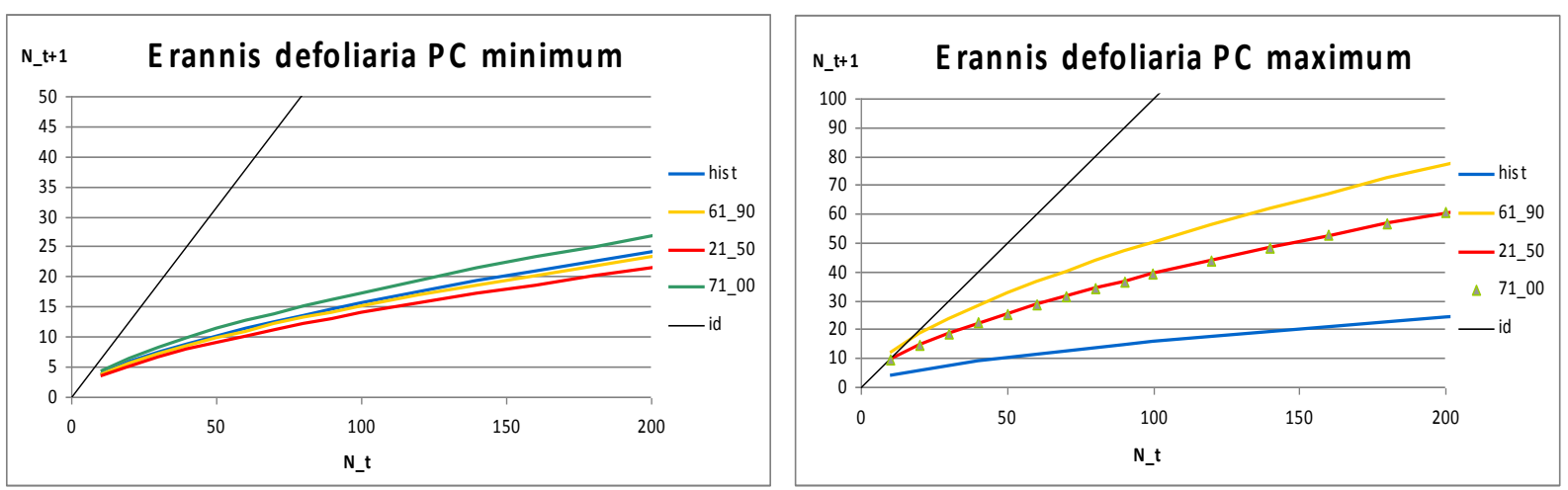

38-39. ábra $A z$ Erannis defoliaria rögzített egyedszámmal induló fökomponenssel bövített modellek által becsült egyedszámának minimum és maximum értékeinek becslése az 1962-2000-es megfigyelt idöszakra, illetve a RegCM3.1 regionális klímamodell 1961-1990-es, 2021-2050-es és a 2071-2100-as idősorai (forrás: a szerző saját szerkesztése)

\section{Colotois pennaria}

A 3 (EMRAIN2, ETMAXX36, RAIN31) indikátorral bővített modellben a klimatikus tényezők jövőbeli becslését figyelembe véve, a rögzített egyedszámmal induló modellek által becsült egyedszámok minimumai hosszútávon nagymértékü egyedszám-csökkenést vetítenek előre az előző évi értékhez viszonyítva. A referencia időintervallumra és a két jövőbeli intervallumra becsült ETMAXX36 eredményei (40. ábra) páronként szignifikánsan eltérnek $(\mathrm{p}<0,05)$ az 1961-1990-es és a 2071-2100-as, valamint 2021-2050-es és 2071-2100-as időszeletek esetében. Az EMRAIN2 (41. ábra) viszont csak a 2021-2050 és 2071-2100 közötti időszeletekben mutatnak szignifikáns eltérést a $t$-próba szerint.
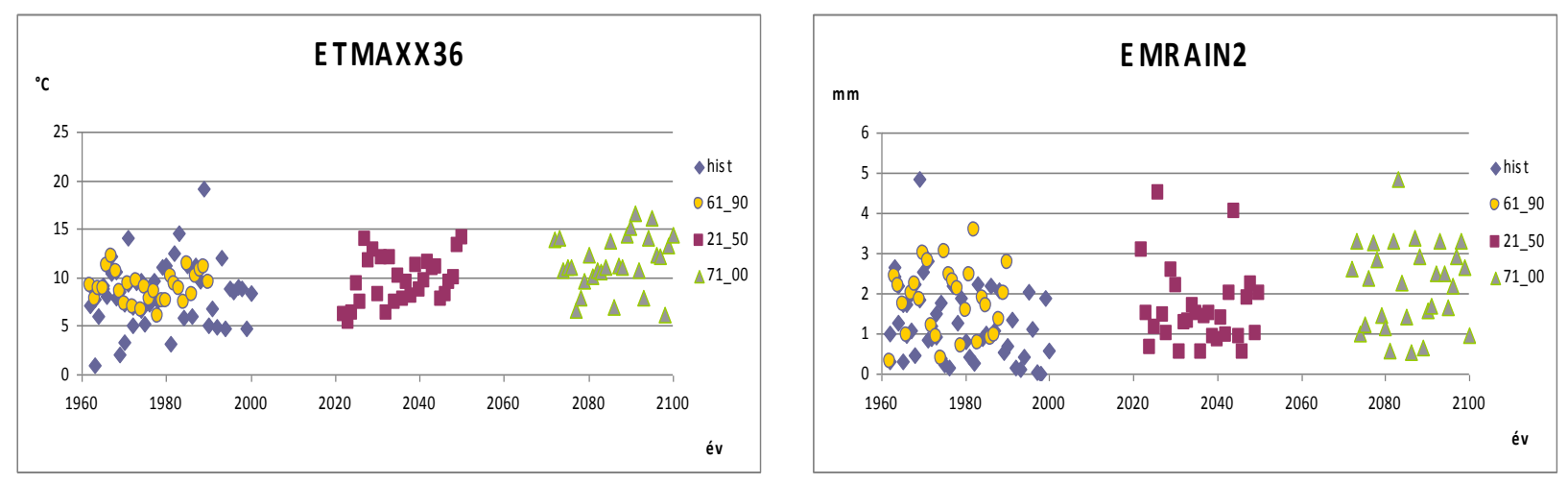

40-41. ábra Az ETMAXX36 és az EMRAIN2 indikátor értékei az 1962-2000-es megfigyelt idöszakra, illetve a RegCM3.1 regionális klímamodell 1961-1990-es, 2021-2050-es és a 2071-2100-as becsült adataiból számítva (forrás: a szerző saját szerkesztése)

Ha a modell által becsült egyedszámok minimumait időszeletenként összehasonlítjuk (42. ábra), akkor a referencia időszakhoz (1961-1990) képest rövidtávon némi emelkedést becsülhetünk, de hosszabb távon (2071-2100) jelentősebb egyedszám-csökkenést jósol a modell. Ha a modell egyedszám-becsléseinek maximum értékeit vizsgáljuk, akkor is csökkenés várható (43. ábra). Az időszeletekre vonatkozó eredmények páronként szignifikánsan eltérnek $(p<0,05)$. 

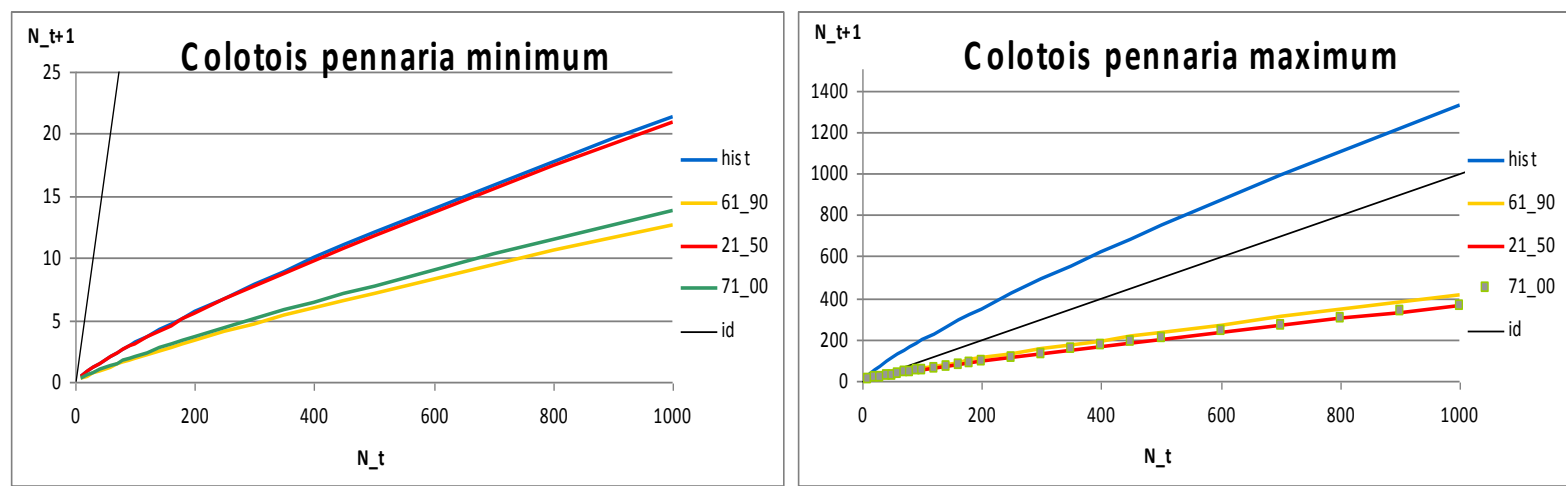

42-43. ábra $A$ Colotois pennaria rögzített egyedszámmal induló indikátorral bövített modellek által becsült egyedszámának minimum és maximum értékeinek becslése az 1962-2000-es megfigyelt idöszakra, illetve a RegCM3.1 regionális klimamodell 1961-1990-es, 2021-2050-es és a 2071-2100-as idősorai (forrás: a szerző saját szerkesztése)

A főkomponenssel bővített modellel is elvégeztük a becsléseket a három időszakra (1961-1990, 2021-2050, 2071-2100) vonatkozóan. A főkomponenssel bővített modell becsült egyedszámainak minimum értékeit figyelembe véve elmondhatjuk, hogy a rögzített induló egyedszámokat változtatva minden esetben csökken a következő évi egyedszám. A következő évi kezdeti becsült értékek csökkenése az alacsonyabb induló egyedszámtól távolodva egyre kisebb mértékủ lehet (44. ábra). Ugyanez a változás fogalmazható meg a 2021-2050-es, és a 2071-2100-as időszelet esetében. Ha az időszeletekre lebontva vizsgálódunk, az adott indulási egyedszámok ismeretében a referenciaidőszakot a 2021-2050 közötti időszakkal összehasonlítva minimálisan nőtt az egyedszám-csökkenés mértéke, a 2021-2050 és a 2071-2100 közötti időintervallumban a csökkenés mértéke a felére zuhanhat.

A faktorral bővített modell egyedszámainak maximum értékeit vizsgálva, első lépésként megállapítjuk, hogy referenciaidőszakban az egyedszámok növekedésével a következő évi becsült egyedszámok magasabbak, de a növekedés üteme mérséklődik (45. ábra). A 2021-2050 időszelet esetén az indulási egyedszámnál kevesebb a következő évben becsült maximális egyedszám. A 2071-2100 időszak esetén csak alacsony induló egyedszám esetében nőhet az egyedszám, nagyobb kezdeti egyedszám értékeknél az azt következő évi egyedszám érteke csökkenését várhatjuk. 

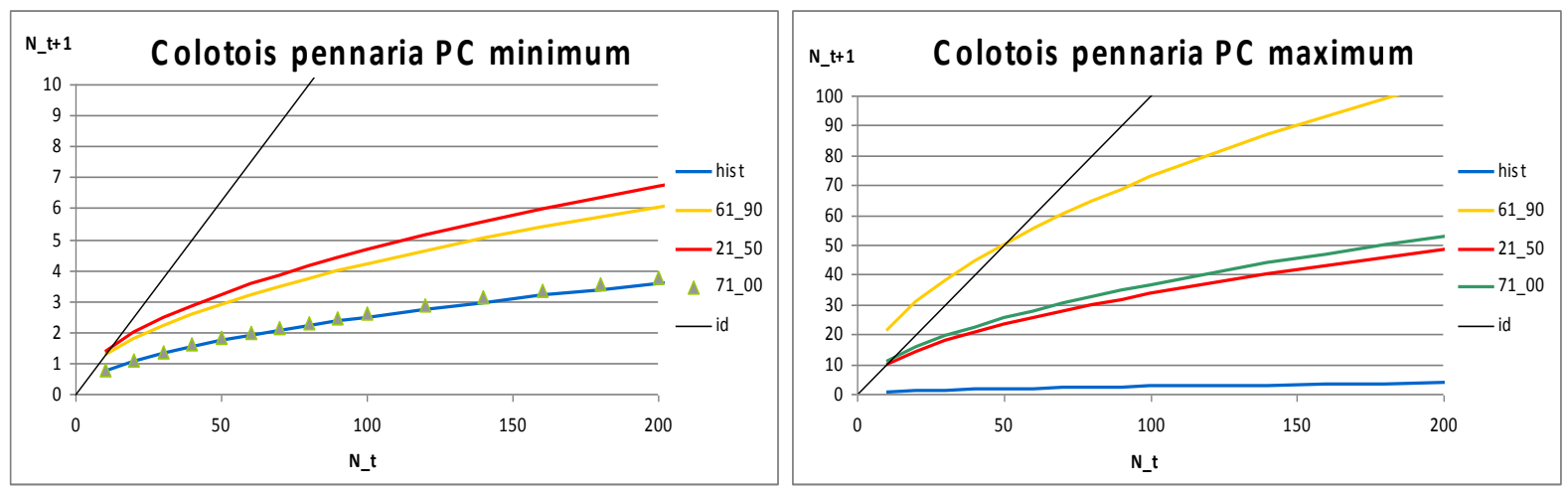

44-45. ábra $A$ Colotois pennaria rögzített egyedszámmal induló fökomponenssel bövített modellek által becsült egyedszámának minimum és maximum értékeinek becslése az 1962-2000-es megfigyelt idöszakra, illetve a RegCM3.1 regionális klimamodell 1961-1990-es, 2021-2050-es és a 2071-2100-as idősorai (forrás: a szerző saját szerkesztése)

\section{Erannis aurantiaria}

Az indikátorral bővített modellben az MRAIN11 klimatikus tényező jövőbeli változását figyelembe véve a faj becsült egyedszám-minimum értékének rövidtávú emelkedésére számíthatunk, de hosszabb távon a csapadék indikátor értékének változása az egyedszám visszaeséséhez vezethet. Vizsgálatom során megállapítottam, hogy a modell a klimatikus indikátorunk magasabb értékeit jósolja, de az időszeletek (1961-1990, 2021-2050, 2071-2100) között nincsen szignifikáns különbség (46. ábra).

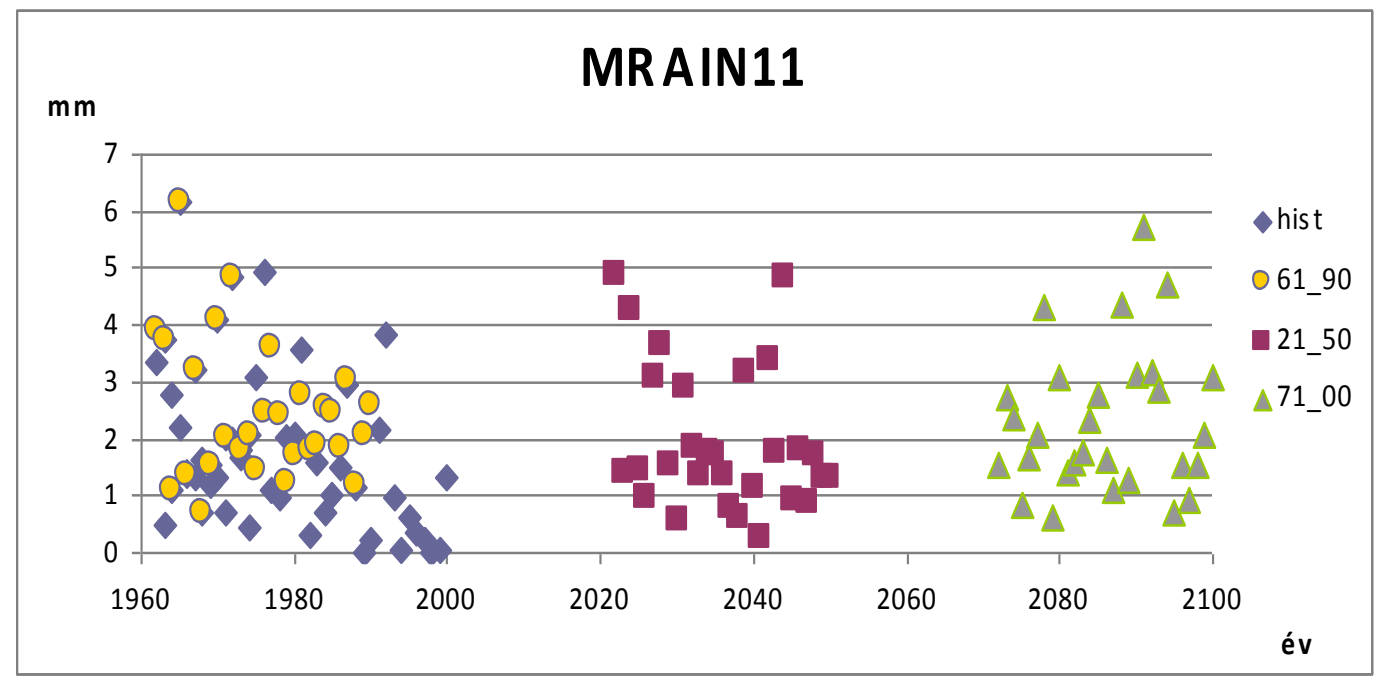

46. ábra Az MRAIN11 indikátor értékei az 1962-2000-es megfigyelt idöszakra, illetve a RegCM3.1 regionális klimamodell 1961-1990-es, 2021-2050-es és a 2071-2100-as becsült adataiból számítva (forrás: a szerzö saját szerkesztése)

Ha becsült egyedszámok minimum és maximum (47-48. ábra) értékeit különböző (rögzített) induló egyedszám esetén vizsgáljuk, összehasonlítva az időszeleteket elmondhatjuk, hogy a bővített modell becslései alapján adott induló egyedszám mellett mind a 2021-2050, mind a 2071-2100-as időszelet esetben alacsonyabb becsült egyedszám várható, rövidtávon (2021- 
2050) kisebb ütemü csökkenést tapasztalhatunk. Az időszeletek becsült egyedszámai páronként szignifikánsan eltérnek $(\mathrm{p}<0,05)$, melyet $t$-próbával igazoltam.
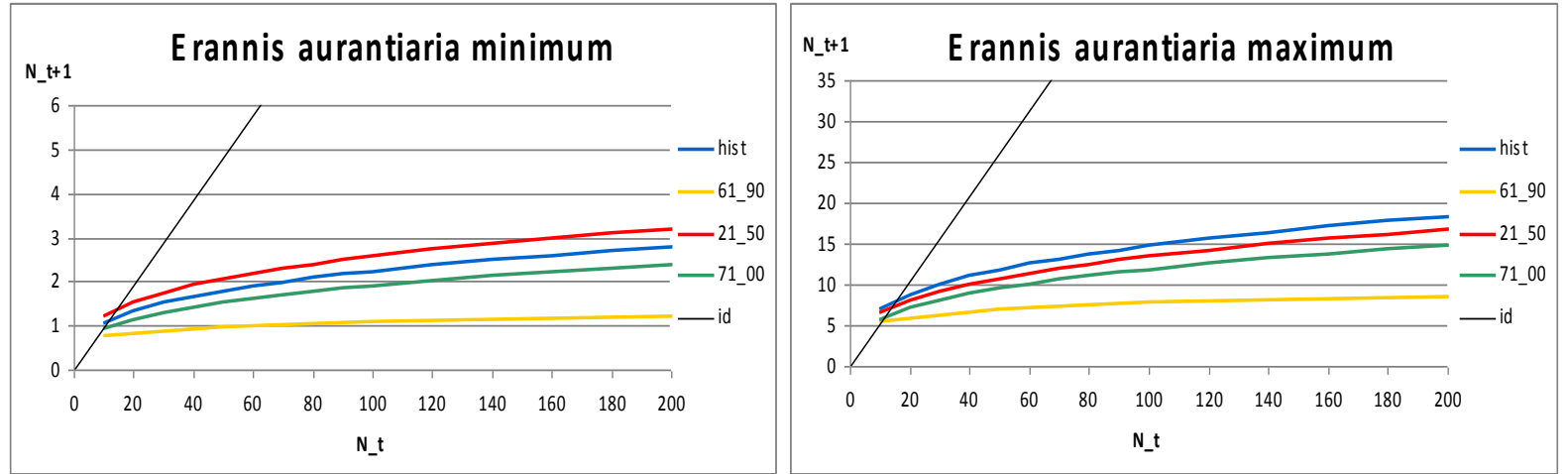

47-48. ábra $A z$ Erannis aurantiaria rögzített egyedszámmal induló indikátorral bövített modellek által becsült egyedszámának minimum és maximum értékeinek becslése az 1962-2000-es megfigyelt idöszakra, illetve a RegCM3.1 regionális klímamodell 1961-1990-es, 2021-2050-es és a 2071-2100-as idösorok páronkénti összehasonlitásával (forrás: a szerzö saját szerkesztése)

A főkomponenssel (49-50. ábra) bővített modellel is elvégeztük az egyedszámbecsléseket a különböző időintervallumokra (referencia időszak, 2021-2050, 2071-2100). A főkomponenssel bővített modell által becsült egyedszámok maximum értékeit vizsgálva a referencia időszakban és a 2021-2050-es és a 2071-2100-as időszeletekben hasonló eredmény várható, mint az indikátorral bővített modellnél.

A főkomponenssel bővített modell által becsült egyedszámok minimum értékeit figyelembe véve is alacsonyabb egyedszámot vetítünk elöre, de a csökkenés mértéke a harmadik időszeletben (2071-2100) nagy mértékben fokozódhat az előző időszakhoz képest. Ha az időszeleteket összehasonlítjuk a becsült egyedszám tükrében, minden esetben ugyanazt a tendenciát kaphatjuk, miszerint a magasabb induló egyedszámok képest egyre alacsonyabb egyedszám várható a következő évi rajzáskor.
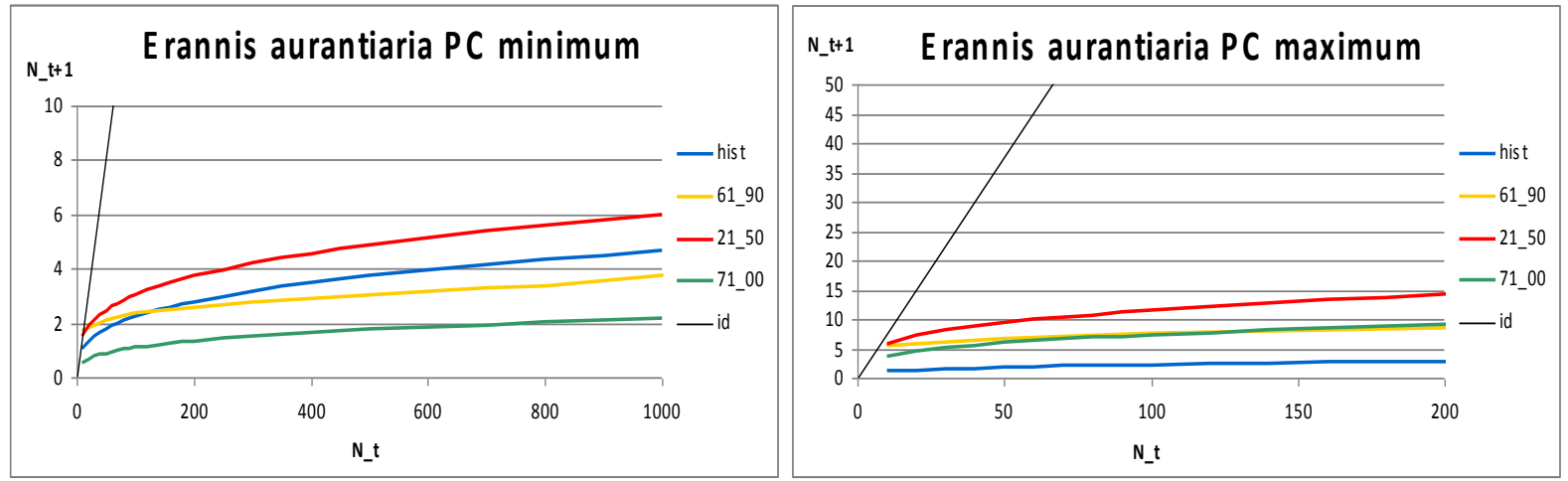

49-50. ábra Az Erannis aurantiaria rögzített egyedszámmal induló fökomponenssel bővített modellek által becsült egyedszámának minimum és maximum értékeinek becslése az 1962-2000-es megfigyelt idöszakra, illetve a RegCM3.1 regionális klimamodell 1961-1990-es, 2021-2050-es és a 2071-2100-as idösorai (forrás: a szerzö saját szerkesztése) 


\section{Idaea dimidiata}

A klímamodell a klimatikus indikátorok (RAIN9, ETMINN1, ETMIN18) értékeinek kismértékü növekedését jósolja (51-52. ábra). A meteorológia tényezők e változása az egyedszám alakulását csak alacsony induló egyedszámnál növeli, a magasabbak esetén már csökkenti. Az egyedszámváltozás a becsült (1961-1990) és az közeljövőbeli idősor (2021-2050) között a RAIN9 esetében szignifikáns ( $\mathrm{p}<0,05)$, míg ETMIN18 és az ETMINN1 esetében az 1961-1990 és 2071-2100, valamint a 2021-2050 és a 2071 és 2100 közötti időszakra becsült várható értékek egymástól szignifikánsan $(\mathrm{p}<0,05)$ eltérnek.
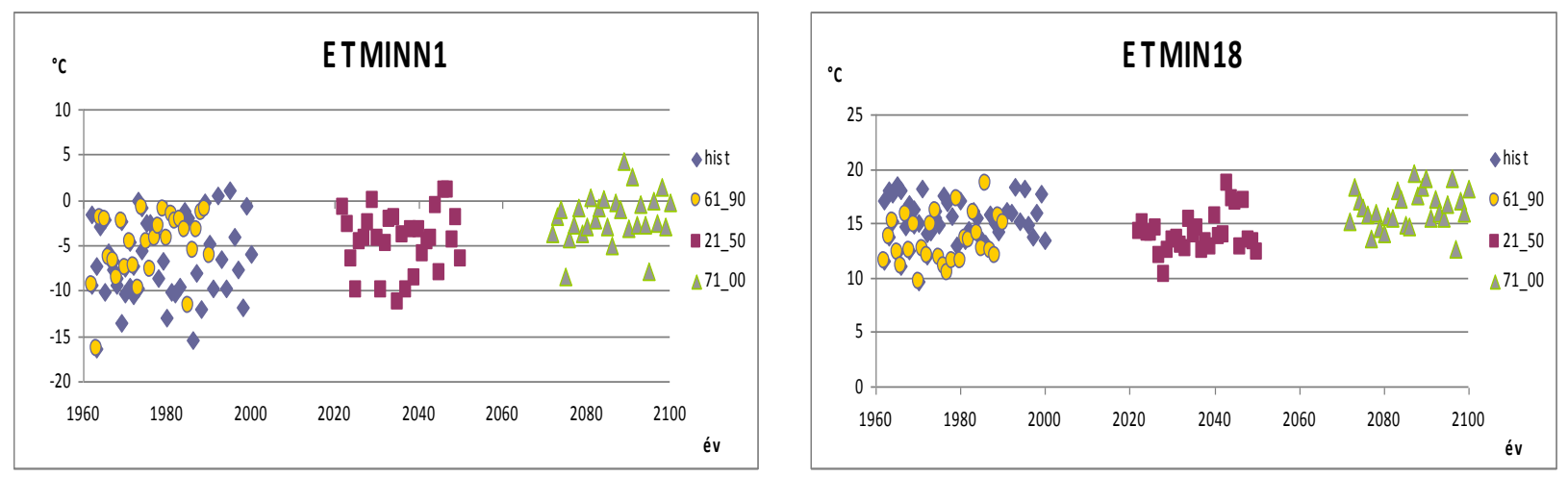

51-52. ábra Az ETMINN1 és ETMIN18 indikátor értékei az 1962-2000-es megfigyelt időszakra, illetve a RegCM3.1 regionális klimamodell 1961-1990-es, 2021-2050-es és a 2071-2100-as becsült adataiból számítva (forrás: a szerzö saját szerkesztése)

Ha a becsült egyedszám minimum értékét tekintjük és a különböző időszeleteket összehasonlítjuk, megállapíthatjuk, hogy 1961-1990-től 2071-2100 időszelet irányába az egyedszám egyre kevésbé emelkedik adott induló egyedszám mellett.

Ha a modell egyedszám-becsléseinek maximum értékeit vizsgáljuk, akkor egyedszámnövekedést várhatunk a referencia időszakban, 2021 és 2050 között, valamint 2071 és 2100 között is. A kezdeti értékek emelésével az egyedszám változást tekintve 2021-2050 időintervallumban mintegy 4000, 2071-2100 időszeletben körülbelül 2500 induló egyedszámig várható az egyedszám növekedése. Ennél magasabb érték esetén egyedszám csökkenésére lehet számítani (53-54. ábra). Az időszeleteket összehasonlítva a távoli jövő felé egyre csökken az egyedszámok növekedésének mértéke. Az időszeletek eredményei páronként szignifikánsan eltérnek $(\mathrm{p}<0,05)$. 

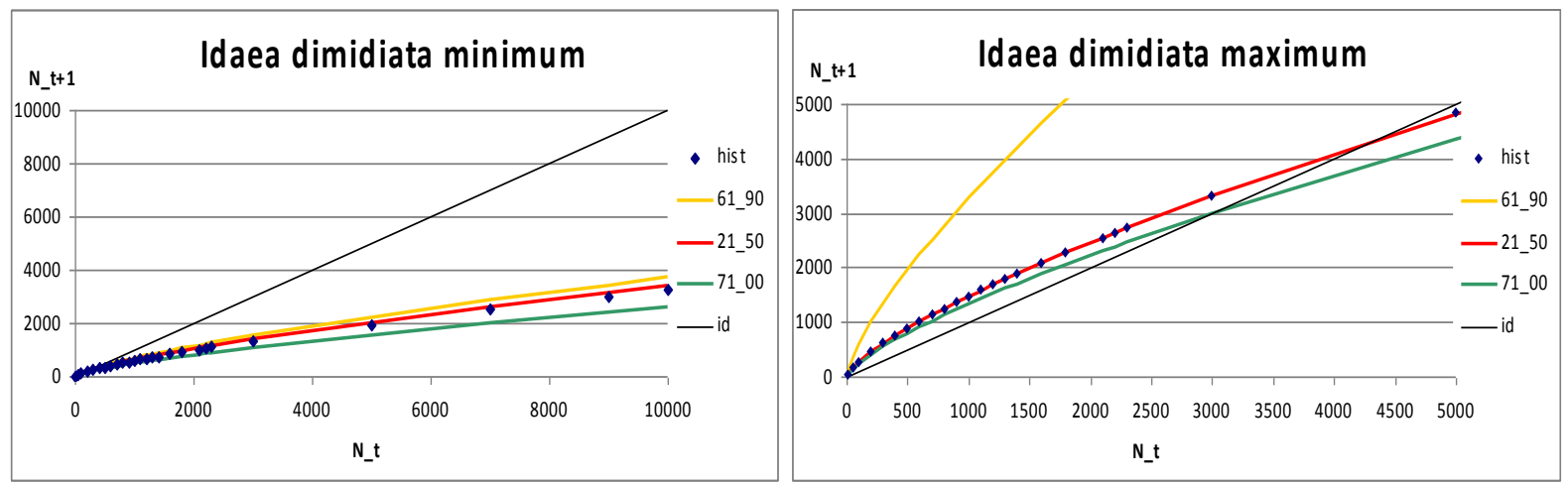

53-54. ábra $A z$ Idaea dimidiata rögzített egyedszámmal induló indikátorral bövített modellek által becsült egyedszámának minimum és maximum értékeinek becslése az 1962-2000-es megfigyelt idöszakra, illetve a RegCM3.1 regionális klimamodell 1961-1990-es, 2021-2050-es és a 2071-2100-as idősorai (forrás: a szerző saját szerkesztése)

A fökomponenssel bővített modellel is elvégeztük a becsléseket a különböző időintervallumokra. A fökomponenssel bővített modell esetén, az egyedszámok minimum értékeinek változása nem számottevő. Megállapítottuk, hogy a referencia időszakban (19611990) kb. 200 induló egyedszámig, míg a másik két időintervallumra (2021-2050, 2071-2100) kb. 150 kezdeti egyedszámig nőhet az egyedszám a következő évben, körülbelül 150 induló egyedszámnál az induló egyedszám a következő évre nem változik, viszont ennél magasabb induló egyedszámnál egyedszám-csökkenést becsül a modell. Az egyedszám-növekedés és az egyedszám-csökkenés mértéke közel azonos, ha összehasonlítom értékét a három vizsgált időszeletben (referencia időszeletben, 2021-2050 között és 2071-2100 között).

A maximum értékeket vizsgálatával kijelenthetjük, hogy a referencia időszakra mintegy 6000 induló egyedszámig számíthattunk volna növekedésre, a későbbi időszeletekben viszont már 3000-4000 kezdeti értéknél következhet be az egyedszám csökkenése az előző évhez képest. $\mathrm{Az}$ egyedszámok alakulását tekintve mindezek ismeretében elmondható, hogy a jövőben a növekedés mértéke ingadozik.
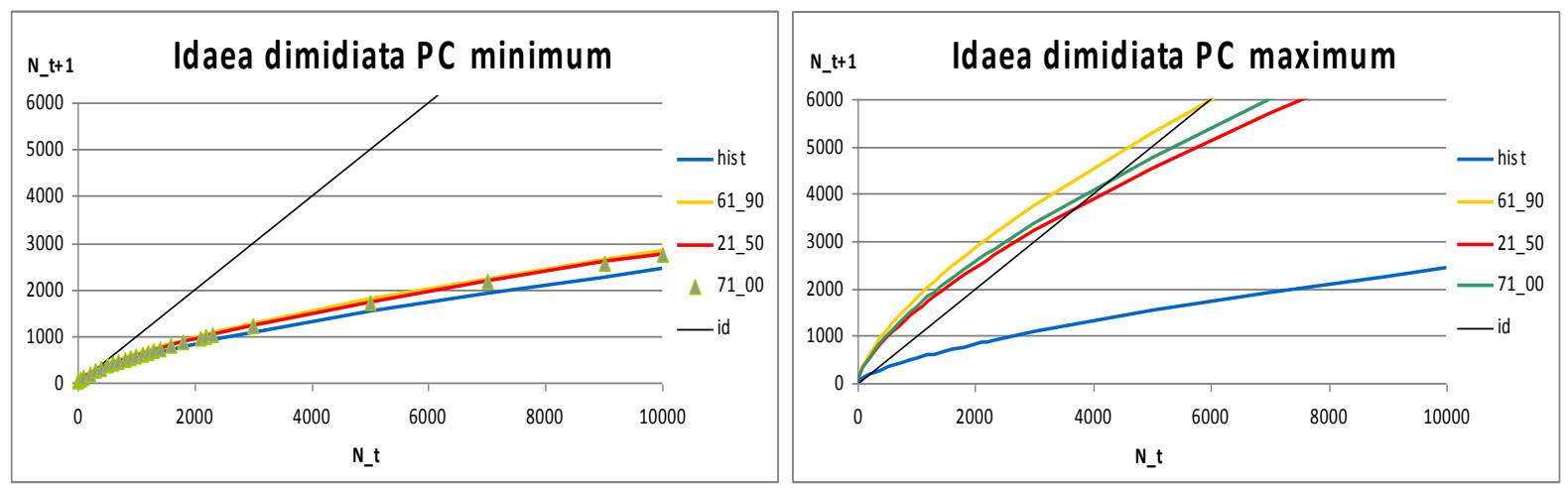

55-56. ábra Az Idaea dimidiata rögzített egyedszámmal induló fökomponenssel bővitett modellek által becsült egyedszámának minimum és maximum értékeinek becslése az 1962-2000-es megfigyelt idöszakra, illetve a RegCM3.1 regionális klímamodell 1961-1990-es, 2021-2050-es és a 2071-2100-as idősorai (forrás: a szerző saját szerkesztése) 


\section{Scopula nigropunctata}

A klimatikus indikátor (ETMIN32) érték a modell becslése alapján magasabb lesz (53. ábra ). A RegCM3.1 klímamodell az előző év november közepi minimumhőmérsékletére a 1961 1990-es időszakra $3,45^{\circ} \mathrm{C}$-ot becsül $(\mathrm{p}<0,001)$, a 2021-2050-es időszakra 3,39 ${ }^{\circ} \mathrm{C}$-ot $(\mathrm{p}<0,001)$, (a referencia-időszak és a 2021-2050-es becslés egymástól nem tér el szignifikánsan, $\mathrm{p}=0,925$ ); a 2071-2100-as időszakra már $6,03{ }^{\circ} \mathrm{C}$-ot prognosztizál $(\mathrm{p}<0,001)$. Az egyedszám-változás különbsége szignifikáns $(\mathrm{p}<0,001)$ a megfigyelt időszakban (1962-2000) és a 2071-2100 időszakára becsült értékekkel. A becsült (1961-1990) és a 2071-2100-as időszelet, valamint a 2021-2050-es és a 2071-2100 között az indikátor változásai szintén szignifikánsak ( $<<0,001)$.

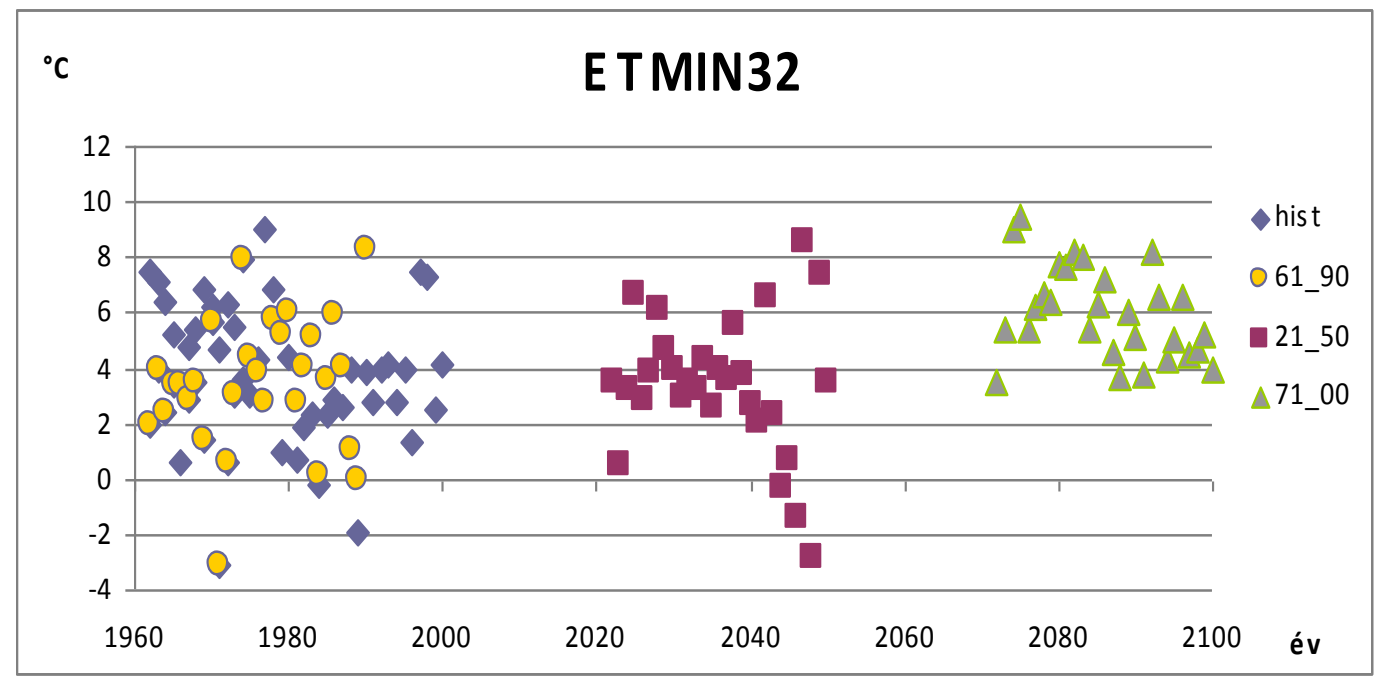

57. ábra Az ETMIN32 indikátor értékei az 1962-2000-es megfigyelt idöszakra, illetve a RegCM3.1 regionális klímamodell 1961-1990-es, 2021-2050-es és a 2071-2100-as becsült adataiból számítva (forrás: a szerzö saját szerkesztése)

Ha becsült egyedszám minimum értékét tekintjük (58. ábra), rövidtávon a referencia időszakkal (1961-1990) megegyezve elmondható, hogy kb. 400 induló egyedszámig a faj következő évi egyedszáma nőhet, ezután viszont csökkenhet. A 2071-2100-as időszeletnél mindez a változás már kb. 350 induló egyedszámnál kialakulhat.

Ha a modell egyedszám-becsléseinek maximum értékeit nézzük (59. ábra), akkor rövidtávon a referencia időszakkal megegyezve elmondható, hogy kb. 1300 induló egyedszámig a faj következő évi egyedszáma magasabb itt is, s ezután alacsonyabb. A 2071-2100-as időszeletnél mindez az egyedszám-növekedés már kb. 800 induló egyedszámnál előkezdődhet. Az időszeletek eredményei páronként szignifikánsan eltérnek $(\mathrm{p}<0,05)$. 

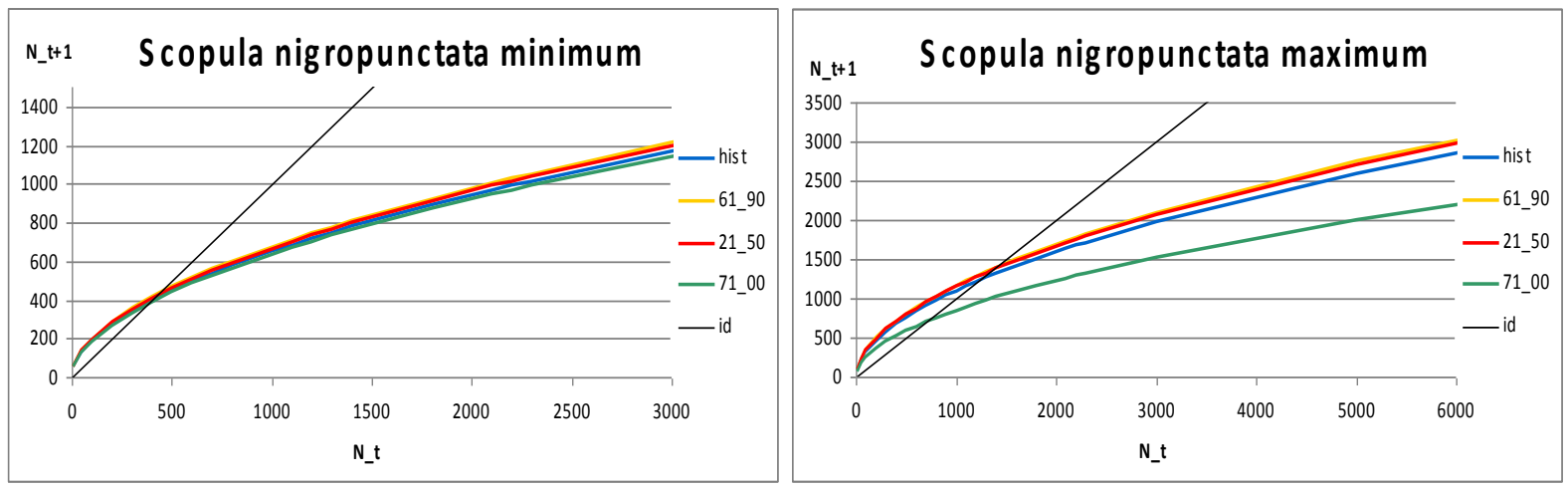

58-59. ábra $A$ Scopula nigropunctata rögzített egyedszámmal induló indikátorral bövített modellek által becsült egyedszámának minimum és maximum értékeinek becslése az 1962-2000-es megfigyelt idöszakra, illetve a RegCM3.1 regionális klímamodell 1961-1990-es, 2021-2050-es és a 2071-2100-as idösorai (forrás: a szerző saját szerkesztése)

A fökomponenssel bővített modellel is elvégeztük a becsléseket a referencia időszakra és a jövő két időszeletére. A főkomponenssel bővített modell esetén, az egyedszámok minimum értékeinek növekedése figyelhető meg a referencia időszakban a kb. 400 induló egyedszámig, majd az alatt kisebb egyedszámokat becsül a modell. A 2021-2050 és 2071-2100 időszeletekre ugyanerre lehet számítani, csak alacsonyabb (kb. 350) induló egyedszámnál (60. ábra). A jövőben az egyedszámok alakulásának változására kisebb mértékben számíthatunk.

A maximum értékeket vizsgálatával kijelenthetjük, hogy a referencia időszakra mintegy 1500 induló egyedszámáig (elérve az eltartó kapacitást) számíthattunk volna növekedésre, a későbbi időszeletekben viszont már 1100-1200 kezdeti értéknél következhet majd be az egyedszám csökkenése az előző évhez képest (61. ábra). Az egyedszámok alakulását tekintve mindezek ismeretében elmondható, hogy a jövőben a növekedés mértéke ingadozhat.
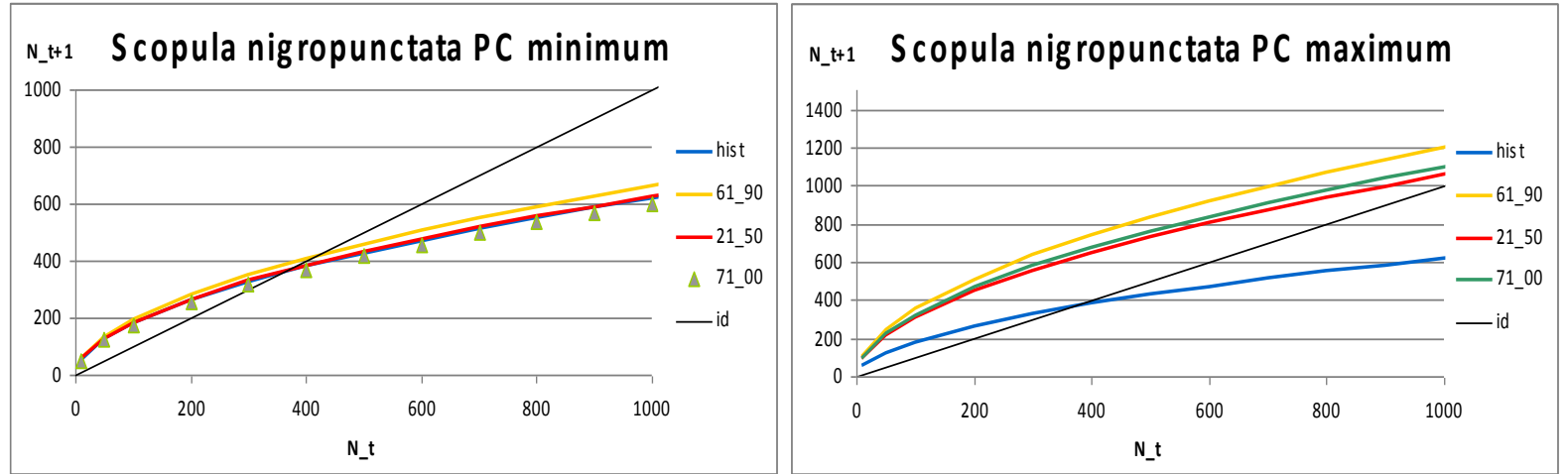

60-61. ábra A Scopula nigropunctata rögzített egyedszámmal induló fökomponenssel bövített modellek által becsült egyedszámának minimum és maximum értékeinek becslése az 1962-2000-es megfigyelt idöszakra, illetve a RegCM3.1 regionális klímamodell 1961-1990-es, 2021-2050-es és a 2071-2100-as idösorai (forrás: a szerzö saját szerkesztése) 


\section{Pelugra comitata}

A RegCM3.1 regionális klímamodell az áprilisi hőmérséklet és csapadék értékek emelkedését jósolja (62-63. ábra). Az indikátorok értékeinek várható növekedése mellett az egyedszámok változásának mértéke ingadozhat a jövőben. A megfigyelt időszakban (1962-2000) a modell becsült indikátorainak értéke a referencia időszakra (1961-1990), valamint a 2071-2100 időszeletre becsülttől szignifikánsan eltérnek $(p<0,05)$. Az ETMIN11 esetében a referencia (1961-190) és a 2021-2050, valamint 1961-1990 és 2071-2100 értékei között szignifikáns különbség van.
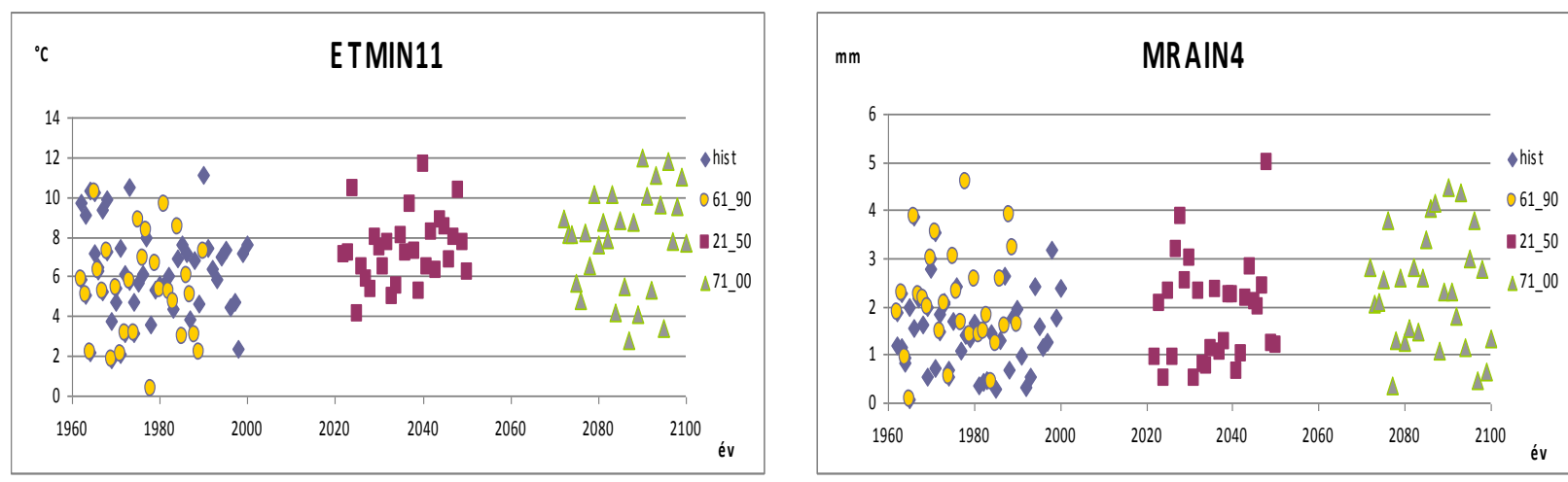

62-63. ábra Az ETMIN11 és az MRAIN4 indikátorok értékei az 1962-2000-es megfigyelt időszakra, illetve a RegCM3.1 regionális klimamodell 1961-1990-es, 2021-2050-es és a 2071-2100-as becsült adataiból számitva (forrás: a szerzö saját szerkesztése)

Ha a modell egyedszám-becslésének minimum értékeit elemezzük, rövidtávon az egyedszám-változás mértéke csökken, majd 2071-2100 időszakban az előzőhöz viszonyítva kismértékben növekedhet. Az egyedszám-változást tekintve mindegyik időszeletre elmondható, hogy kb. 100 induló egyedszám értékig (referencia időszakban 200) egyedszám-növekedést becsül (64. ábra).

Ha a modell egyedszám-becsléseinek maximum értékeit nézzük, akkor elmondhatjuk, hogy a referenciaidőt és a 2021-2050-es idősort összehasonlítva a változás mértéke alacsonyabb, az egyedszám-csökkenés mértéke kisebb, s 2071-2100 időszakban pedig stagnálhat. Az adott egyedszámoknál az 1100-as induló egyedszámok felett a következő évi egyedszámok nem változnak, ezt követően egyedszám-csökkenést várhatunk a jövőben (65. ábra). Az időszeletek eredményei páronként szignifikánsan eltérnek $(\mathrm{p}<0,05)$. 

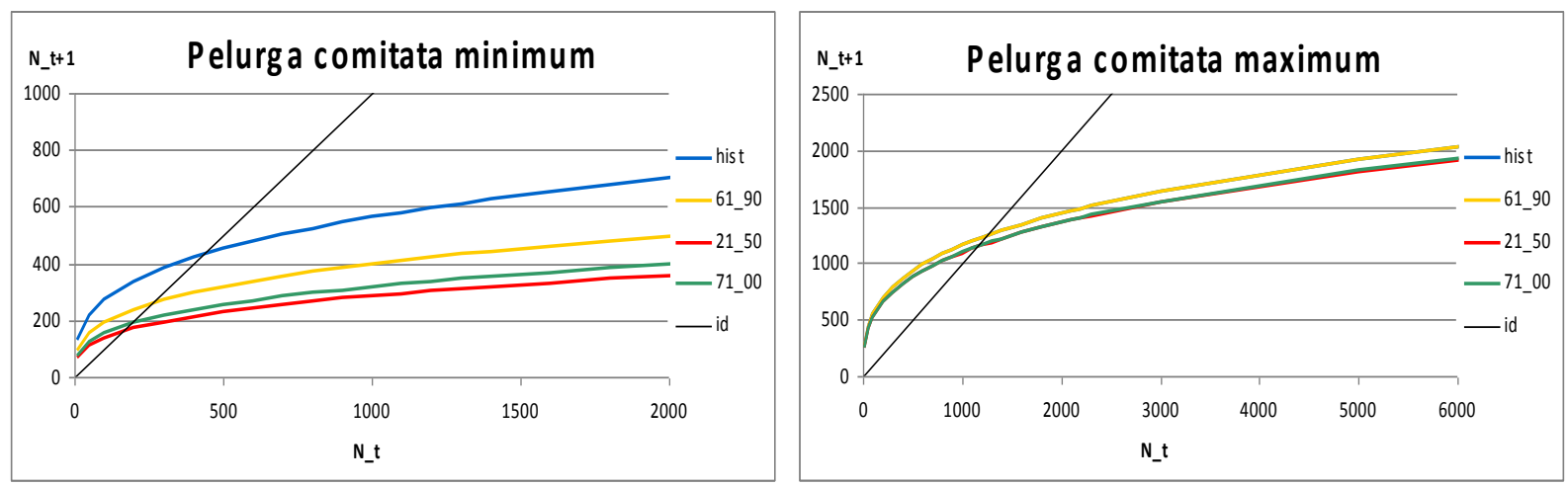

64-65. ábra $A$ Pelurga comitata rögzített egyedszámmal induló indikátorral bővített modellek által becsült egyedszámának minimum és maximum értékeinek becslése az 1962-2000-es megfigyelt idöszakra, illetve a RegCM3.1 regionális klímamodell 1961-1990-es, 2021-2050-es és a 2071-2100-as idösorai (forrás: a szerző saját szerkesztése)

A főkomponenssel bővített modellel is elvégeztük az egyedszám-becsléseket mind a referencia időszakra, 1961-1990-re, mind pedig a 2021-2050-es és a 2071-2100-as időszeletekre. Az így bővített modellnél a különböző időszeletek között nem számíthatunk jelentős változásra. A becsült egyedszám minimum értékét vizsgálva az egyedszám-növekedés várható mintegy 300400 induló egyedszámig, s ezen értéknél stagnálásra, majd ezen érték felett az következő években egyedszám csökkenést jósolunk (66. ábra).

A maximum értékeket vizsgálatával a referencia időszakhoz viszonyítva az egyedszámok $(1248,98)$ alakulásában némi egyedszám-csökkenést becsül a modell a későbbiekben, mind a 2021-2050 között (1178,60), mind a 2071-2100 között (1181,34). Az egyedszám változást tekintve itt is elsősorban növekedésről beszélhetünk, a referenciaidőben az emelkedés 2000 kezdeti értékig valószínűsíthető, míg a 2021-2050 és 2071-2100 időszeletre az induló egyedszám 1700-ra becsülhető, majd ezen értékeket követően egyedszám csökkenésre lehet számítani (67. ábra).
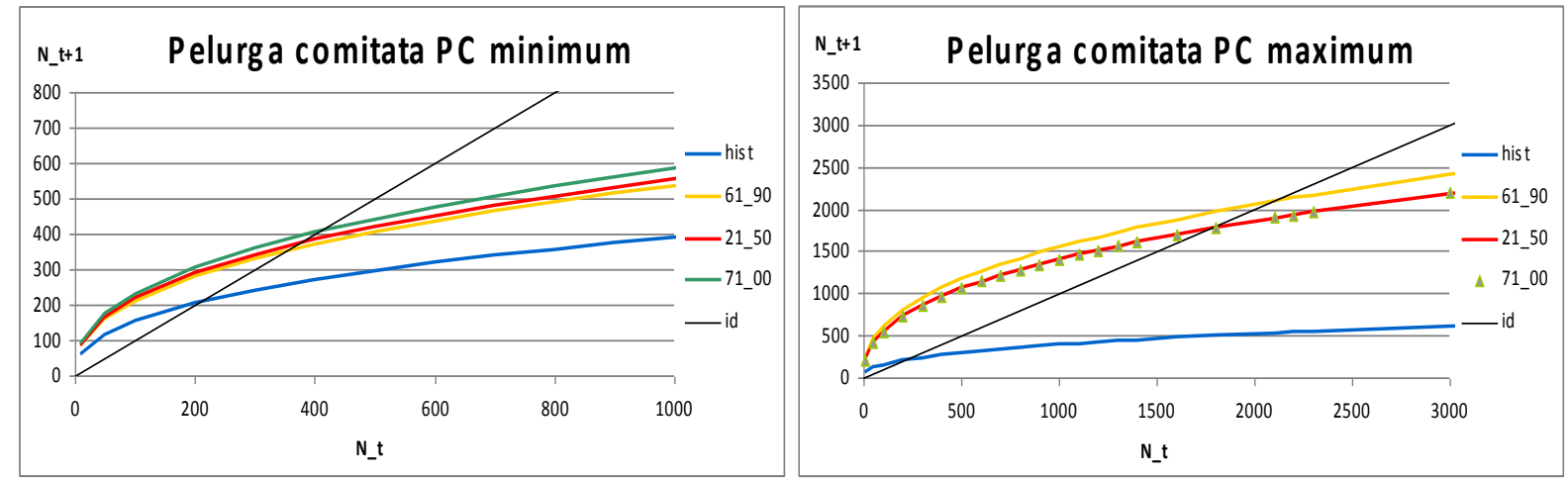

66-67. ábra A Pelurga comitata rögzített egyedszámmal induló fökomponenssel bövített modellek által becsült egyedszámának minimum és maximum értékeinek becslése az 1962-2000-es megfigyelt idöszakra, illetve a RegCM3.1 regionális klimamodell 1961-1990-es, 2021-2050-es és a 2071-2100-as idösorai (forrás: a szerzö saját szerkesztése) 


\section{Eulithis pyraliata}

A jövőben az ERAIN9 klímaindikátor, a márciusi csapadék mennyisége a referencia időszakot (1961-1990) követően 2021-2050 időszakban szignifikánsan csökkenhet (68. ábra). Az indikátor értékeinek csökkenése mellett egyedszám-csökkenést jósol a modell a 2021-2050-es időszeletben.

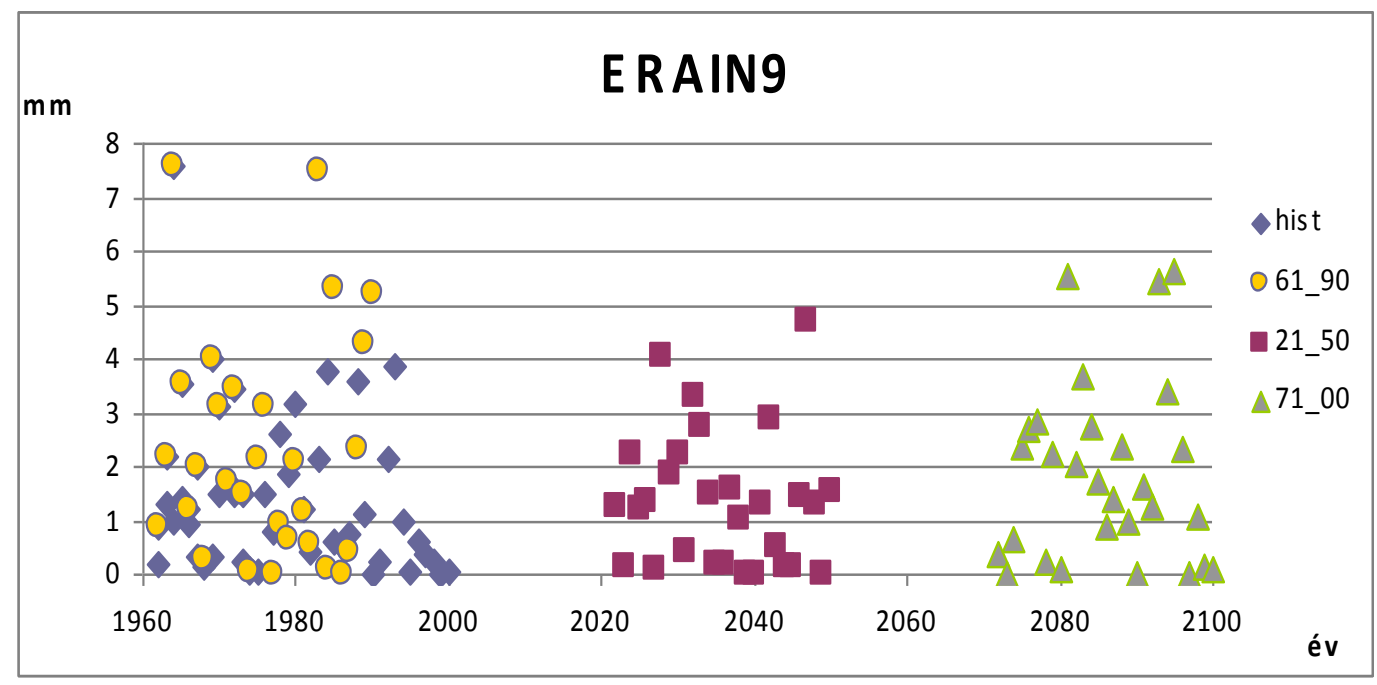

68. ábra Az ERAIN9 indikátor értékei az 1962-2000-es megfigyelt idöszakra, illetve a RegCM3.1 regionális klímamodell 1961-1990-es, 2021-2050-es és a 2071-2100-as becsült adataiból számítva (forrás: a szerzö saját szerkesztése)

Ha a becsült egyedszám minimum értékét nézzük, az egyedszám-változást tekintve mindegyik időszeletre elmondható, hogy kb. 300 induló egyedszámig az egyedszám a következő évben magasabb lehet. Kivételt képez a 2021-2050 időszelet, ahol az az induló egyedszám ameddig az egyedszám növekedhet, alacsonyabb (200), melynek oka a RAIN9 csökkenésével magyarázható (69. ábra).

Ha a modell egyedszám-becsléseinek maximum értékeit tekintjük, az egyedszám értéke a környezet eltartó képességének határáig nőhet, mind a referencia időintervallumban (1961-1990) és mind a két vizsgált 2021-2050-es és a 2071-2100-as jövőbeli időszeletben (70. ábra). Az időszeletek eredményei páronként szignifikánsan eltérnek $(\mathrm{p}<0,05)$. 

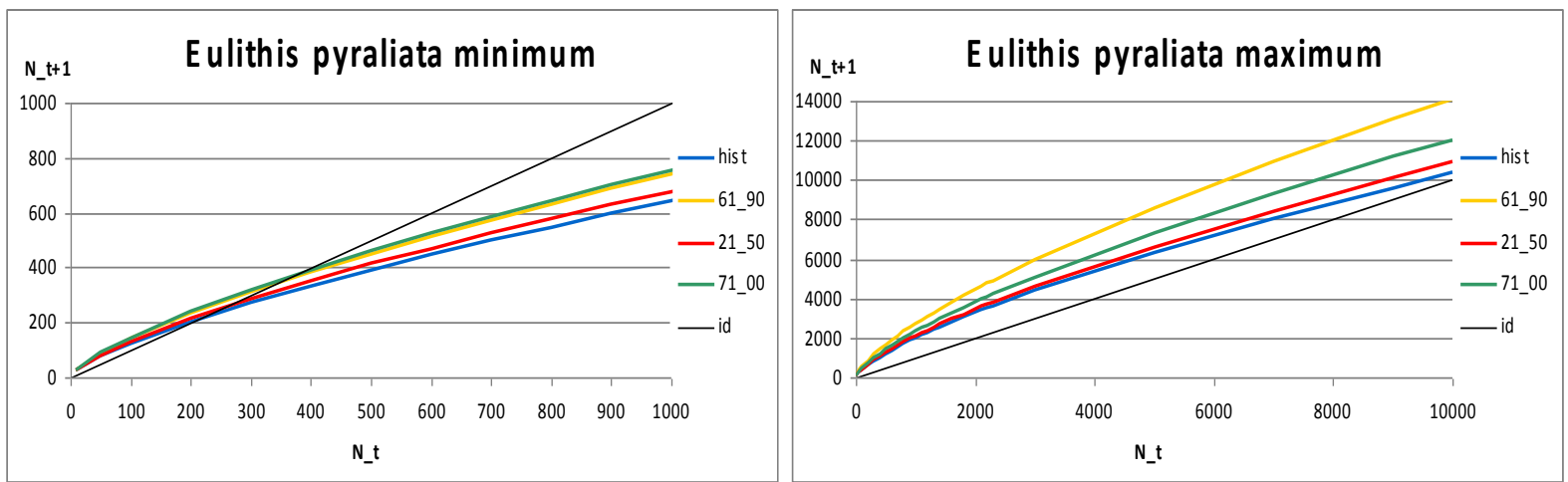

69-70. ábra Az Eulithis pyraliata rögzitett egyedszámmal induló indikátorral bövített modellek által becsült egyedszámának minimum és maximum értékeinek becslése az 1962-2000-es megfigyelt idöszakra, illetve a RegCM3.1 regionális klimamodell 1961-1990-es, 2021-2050-es és a 2071-2100-as idősorai (forrás: a szerző saját szerkesztése)

A fökomponenssel bővített modellel is elvégeztük a becsléseket a három becsült időszeletekre. A becsült egyedszám minimum értékeit tekintve ugyanaz a tendencia figyelhető, meg mint a fent leírt indikátorral bővített modell értékeinek minimumánál (71. ábra).

A becsült egyedszám maximum értékeket vizsgálva, a referencia időszak (1961-1990) az és a jövő két becsült időszeletének (2021-2050, 2071-2100) értékei között szignifikáns változás nem várható az egyedszám változását tekintve. Az adott év 2500-3000 induló egyedszámáig nöhet a következő év egyedeinek száma (72. ábra).
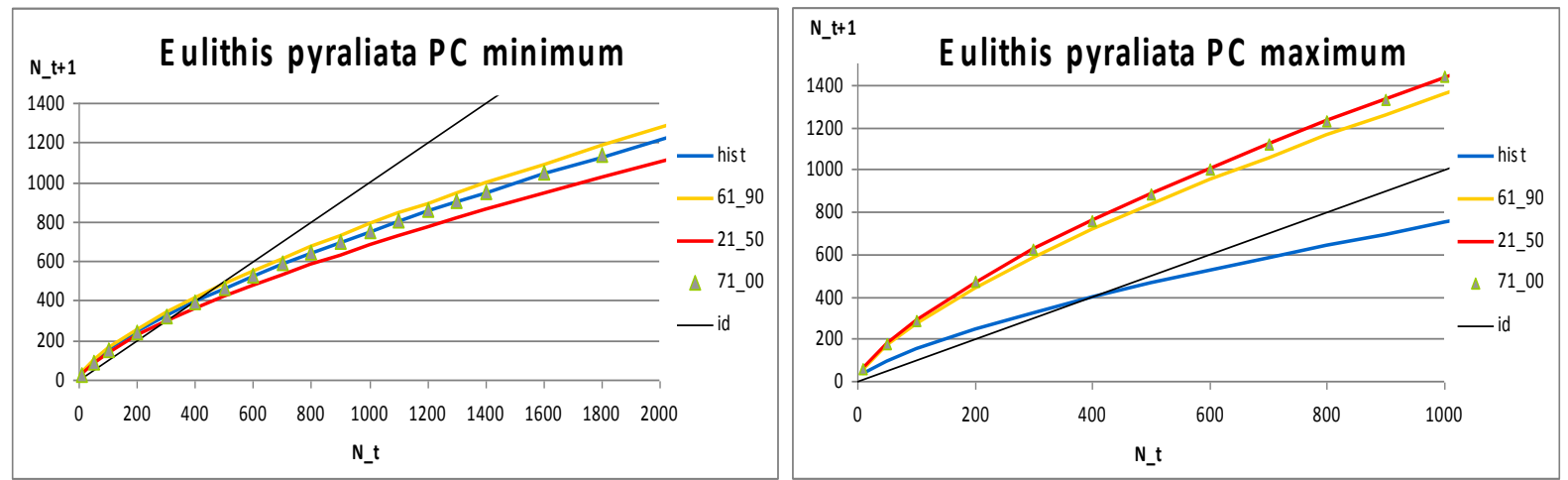

71-72. ábra $A Z$ Eulithis pyraliata rögzített egyedszámmal induló fökomponenssel bövített modellek által becsült egyedszámának minimum és maximum értékeinek becslése az 1962-2000-es megfigyelt idöszakra, illetve a RegCM3.1 regionális klímamodell 1961-1990-es, 2021-2050-es és a 2071-2100-as idösorai (forrás: a szerző saját szerkesztése) 


\subsection{A kutatás új és újszerű tudományos eredményei:}

1. Az 1962 és 2000 közötti időszakban az Országos Erdészeti Fénycsapda-hálózat által begyüjtött lepkeadatokból kiválasztott négy kártevő araszoló faj (O. brumata, $C$. pennaria, E. aurantiaria, E. defoliaria) rajzáskezdetének időbeli alakulását, illetve a rajzáskezdet-rajzáshossz egymással való összefüggését vizsgáltam. A vizsgálatot az 1972-1988-as időintervallumra vonatkozóan a rajzáskezdetre és a rajzás hosszára logisztikus regressziós modellt illesztve, az idő függvényében végeztem el. Megállapítottam, hogy a rajzáskezdet időpontja és a rajzáshossz között szignifikáns lineáris negatív korreláció van. Mind a négy vizsgált lepkefajra elmondható, hogy az imágója minél később jelenik meg, a rajzás ideje úgy lerövidül. Az egyik jelentős kártevőnk, O. brumata esetében megmutattam, hogy a megfigyelt rajzáskezdetek eloszlása a 2021-2050-es időszakra még több késői rajzáskezdet becsül, valamint a rajzáskezdetek várható terjedelme 9 nappal nő a megfigyelthez képest. Az extrém késői (november közepi) rajzáskezdetek gyakorisága várhatóan növekedni fog, ami valószínűleg igen rövid rajzáshosszal párosul majd.

2. A vizsgált nyolc lepkefaj esetében fenológiától függő, fajspecifikus indikátorrendszert dolgoztam ki olyan elemekkel, melyeknek az egyedszámmal, illetve annak változásával szignifikáns összefüggését bizonyítottam.

3. A vizsgált nyolc lepkefaj esetében differenciaegyenleten alapuló egyszerü populációdinamikai modellt írtam fel az egyedszám alakulására, ezt kiegészítve készítettem egy fajspecifikus klimatikus paramétereket is figyelembe vevő populációdinamikai modellt is. Az alapmodell és a klimatikus indikátorokkal bővített kétféle modell becsléseit összehasonlítva megmutattam, hogy az időjárási tényezőket is figyelembe vevő modellek esetén pontosabb eredményt kaptunk. A kutatásba bevont lepkék 40 éves adatsorát elemezve az 1961-2000 közötti időszakra évenként 37 dekádra és 12 hónapra alkotott klímaindikátorokat vizsgálva kimutattam, hogy gátolja az egyedszám-növekedést: az $O$. brumata esetében az előző év március közepi maximumhőmérsékletek emelkedése; az E. defoliaria-nál az októberi minimumhőmérsékletek emelkedése; a $C$. pennaria-nál az vizsgált évet megelőző december közepi maximumhőmérsékletek emelkedése; az E. aurantiaria esetében a novemberi csapadék mennyiségének emelkedése; az I. dimidiata-nál a vizsgált évet 
megelőző január eleji hőmérsékleti minimum, és a június végi minimumhőmérsékleteinek emelkedése; a $S$. nigropunctata esetében az előző év november közepi minimumhőmérséklet emelkedése; a $P$. comitata-nál az áprilisi csapadékértékek és az előző évi április közepi hőmérsékleti minimumok növekedése. Magas egyedszámot eredményezett: a $C$. pennaria esetében az előző év februári; az $I$. dimidiata-nál a március végi; az Eulithis pyraliata esetében az előző évi január, március és november végi nagyobb csapadékmennyiség.

4. A bővített modelleket a RegCM3.1 regionális klímamodell 1961-1990-es referenciaidőszakra, valamint a 2021-2050-re és a 2071-2100-as jövőbeli időszeletekre vonatkozó becsléseivel is futtattam. A klímamodell a klímatényezők 30-30 évre vonatkoztatott becslése szerint az egyedszámok alakulásában a $S$. nigropunctata esetében szignifikáns változás nem várható. A vizsgált fajok közül valószínüleg csupán két fajnak, az Eulithis pyraliata-nak és az átlagértékeket tekintve hosszútávon az O. brumata egyedeinek fog kedvezni a jövő. Ezzel ellentétben a klimatikus viszonyoknak a RegCM3.1 által becsült változása várhatóan kedvezőtlenül befolyásolja az E. aurantiaria, E. defoliaria, I. dimidiata, és $C$. pennaria egyedszámát. Rövidtávon a $P$. comitata egyedszámát is csökkentheti, de ennél a fajnál a becsült egyedszám maximumban stagnálást is prognosztizálhatunk. 


\section{KÖVETKEZTETÉSEK ÉS JAVASLATOK}

Magyarország Európa legsérülékenyebb régiójának határán fekszik, ahol a jelentős hőmérséklet-emelkedés és a csökkenő csapadékmennyiség együttes hatása érződik. A klímaváltozás érzékenyen fogja érinteni hazánk biodiverzitását is (EU Green Paper, 2007).

A Kárpát-medencében valószínűleg a jövőben szárazabbá válik a klíma, ami jelentősen fogja érinteni a rovarvilágot (Czúcz et al., 2007), hiszen a rovarok életére jelentős hatással van a külső környezet. Fejlődésükben nagy szerepet játszik a csapadék és a hőmérséklet, mert ezek a tényezők gyorsíthatják vagy lassíthatják a rovarok életfolyamatait.

Az araszolólepkék populációdinamikai vizsgálatainak kiemelt jelentősége van hazánkban az erdővédelem és a növényvédelem terén, hiszen a vizsgált fajok közül a téliaraszolók a legnagyobb területi tarrágásokat okozó rovarok közé sorolhatók.

A dolgozat anyagát képező nyolc lepkefaj (O. brumata, C. pennaria, E. aurantiaria, E. defoliaria, P. comitata, I. dimidiata, S. nigropunctata, E. pyraliata) vizsgálati eredményeiből a következőket állapítottam meg:

A lepkék rajzáskezdetének időpontja és a rajzáshossz között szignifikáns negatív korrelációt tudtam kimutatni, azaz az imágó minél későbbi megjelenésével, a rajzás ideje lerövidül. Megmutattam, hogy a rajzáskezdetek és rajzáshosszak a vizsgált időszakban logisztikus görbével leírható módon változtak. Továbbá megállapítottam az $O$. brumata esetében a rajzás későbbre tolódását. Eredményemmel megegyező megállapításra jutott korábban Buse és Good (1996) is e faj tekintetében. Más lepkefajnál (Xestia xanthographa) is állapítottak meg későbbi rajzást 20 évnyi adatok elemzése során (Woiwod et al. 1997).

Ezzel ellentétben különböző lepkefajok esetében korábbi rajzást tapasztalt több kutató is: Roy és Spark (2000) a középhőmérséklet évi $1{ }^{\circ} \mathrm{C}$-nyi emelkedése során 2-10 nappal korábban jelenik meg a lepkék zöme a Brit-szigeteken és a rajzáscsúcsuk is ezt követi. Mediterrán klímán élő 23 kaliforniai lepkefaj 31 éves adatsorát vizsgálva Forister és Shapiro (2003) 42 nappallal korábbi megjelenést tapasztaltak. Hasonló eredményekre jutottak a spanyol nagylepkék 15 éves adatsorát vizsgálva, ahol 19 lepkefajból 8 első észlelése korábban történt (Stefanescu et al., 2003); Hollandiában 104 Microlepidoptera fajt vizsgálva 11,6 nappal korábban észlelték az első példányokat 20 éves időintervallumot vizsgálva (Ellis et al., 1997). Ausztráliában a Heteronympha merope lepkével kapcsolatban 65 évnyi adatokat elemezve 10 évenkénti másfél napnyi korábbi rajzáskezdetet állapítottak meg (Kearney et al., 2010). 
Az egynemzedékes araszoló lepkefajok populációdinamikai habitusának leírását differenciaegyenleten és indikátoranalízisen alapuló populációdinamikai modellezéssel (alapmodell) végeztem, s ezután az OMSZ megfigyelt napi adataiból a rovar fenológiai fázisaitól függő klimatikus igényeinek megfelelően az egyedszámmal magas korrelációban álló klimatikus indikátorokat definiáltam, melyek lineáris kombinációit additív tényezőként illesztettem a modellbe. Az alapmodell és a klimatikus indikátorokkal bővített modell becsléseit összehasonlítva megmutattam, hogy az időjárási tényezőket is figyelembe vevő modellek esetén pontosabb eredményt kaptam.

A modelleket az indikátorokból képzett főkomponesekkel mint additív tényezőkkel való bővítésével fejlesztettem. A kutatásba bevont lepkék 40 éves adatsorát elemezve az 1961-2000 közötti időszakra évenként 37 dekádra és 12 hónapra alkotott klímaindikátorokat vizsgálva az alábbi eredményt kaptam:

\section{A, Kártevő téli araszolók:}

A kis téliaraszoló ( $O$. brumata): A klímaindikátorral bővített modellek eredménye alapján megállapítom, hogy az elöző évi március közepi időjárás nagymértékben befolyásolta az egyedszámok alakulását. A korábban publikáltak szerint a késő tavaszi fagyok jelentős lárvapusztulást okozhatnak (Bognár és Huzián, 1979), eredményem szerint a lárva kikelésekor minél magasabb a hőmérséklet, annál nagyobb egyedszám várható a következő évben. Azt a megállapítást, hogy tömegszaporodását a meleg száraz tavaszi időjárás segíti elő, míg a hideg, esős tavaszi időjárás gátolja, e vizsgálat eredménye tehát megerősíti. Továbbá a főkomponenssel bővített modell eredménye alapján megállapítom, hogy az augusztus közepi maximumhőmérséklet szintén pozitív korrelációt mutat az egyedszám-növekedéssel, az augusztusi csapadék pedig gátolja az egyedszám növekedését, mivel értékei negatív korrelációban állnak az egyedszámmal. Leskó és munkatársainak (1999) eredményét, miszerint az $O$. brumata gradációinak kitörését elősegíti a száraz-aszályos klímájú évek, annyiban igazoltam én is, hogy a március közepi hőmérsékleti értékeinek emelkedése elősegíti az egyedszám növekedését, a nagyobb csapadékmennyiségének pedig gátolja a populáció egyedszám-növekedését.

A nagy téliaraszolónál ( $E$. defoliaria) esetében a klímaindikátorral bővített modellek eredménye során elmondható, hogy az október hónap minimumhőmérséklete szignifikáns negatív korrelációt mutat az egyedszámmal. Azokban az években, amikor az októberi 
minimumhőmérsékletek $-1^{\circ} \mathrm{C}$, vagy az alatti értéket mutattak, elősegítette a lepkék egyedszámának növekedését. Ha az októberi minimumhőmérséklet $3^{\circ} \mathrm{C}$, vagy a fölötti érték volt, akkor az egyedszám növekedését gátolta. Továbbá megállapítottam, hogy a faj 1974-es évi kiugró gradációját az előtte lévő évek, pontosabban 1968-tól 1973-ig, alacsony októberi minimumhőmérsékleti értékei is elősegítették. Az 1973-as évi egyedszám visszaesést pedig az adott év októberi minimumhőmérséklet jelentős emelkedése elősegíthette. A modellbe választott két fökomponens vizsgálata során kimutattam, hogy az áprilisi minimumhőmérsékletek, az április közepi átlaghőmérsékletek, az augusztusi maximumhőmérsékletek és az október véginovember eleji csapadék mennyiség pozitív korrelációban áll az egyedszámmal, míg a december mások felében hulló csapadék és az előző év márciusi csapadék mennyiségének alakulása negatív korrelációt mutat az egyedszámmal. Szignifikáns negatív korrelációt állapítottam meg az előző év márciusi csapadékmennyiség és az egyedszám között, ami a márciusban kelö lárvákra van hatással. Megállapítottam, hogy általában azok az évek, amikor október végén november elején a csapadék 3,5 mm felett volt, kedveztek az egyedszám-növekedésnek a következő évben. Viszont az 1971-es és az azt megelőző 3 év ezen időszaka is száraz volt (0-0,1 mm csapadék). 1971-ben a lepkék tömeges elszaporodását figyelhettük meg. Eredményeimmel alátámasztom egyes szakemberek állítását, miszerint a téli araszolók populációszintjét az aszályos évek megnövelik (Leskó et al., 1998; Szentkirályi et al., 1998). Modelleim eredménye alapján elmondható, hogy a melegkedvelő lárvák fejlődését elősegítheti az emelkedő tavaszi hőmérséklet és gátolhatja a márciusi csapadék. A lepkék őszi kikeléséhez, ugyanúgy, mint a kis téliaraszolónál, csapadék szükséges (Tóth, 1999), ezt látszik igazolni eredményeim is, hisz az október végi - november eleji csapadék pozitív korrelációt mutatott az egyedszám alakulásával.

A tollascsápú (téli) araszoló (C. pennaria) a klímaindikátorokkal bővített modellek esetében a faj egyedszámának alakulása és a februári és augusztusi csapadék, áprilisi és novemberi hőmérséklet értékei között pozitív korrelációt találtunk, míg a decemberi hőmérséklettel negatív korreláció áll fenn. Szignifikáns növekedés következett be, amikor az előző év februárja és az október vége - november eleje csapadékos volt. Viszont a lepkék elszaporodását gátolja az előző év december közepének magas hőmérsékleti maximuma. Ezt látszik igazolni az 1971-ben kiugró gradációt követő nagyarányú egyedszám visszaesés (egyedszám és hőmérséklet-változás 1971-ről 1972-re: $26,8 \rightarrow 3,38 ; 14,1^{\circ} \mathrm{C} \rightarrow 5^{\circ} \mathrm{C}$ ). A főkomponensekkel bővített modell vizsgálata esetén a főkomponensekkel szignifikáns kapcsolatban álló indikátorok közül pozitív korrelációt mutatnak a februári és augusztusi csapadék értékek. Ebből arra következtetek, hogy a februári csapadék a lárvák, míg az augusztusi (napi átlag 2 mm-t meghaladó) csapadék az imágók 
kikelését segíti elő. Az imágók kikelésében szerepet játszhat a szeptemberi rajzást megelőző augusztusi csapadék is, mely elősegíti az egyedszám-növekedést.

Az aranysárga téliaraszoló (E. aurantiaria) a klímaindikátorral bővített modell eredménye alapján megállapítottam, hogy a novemberi csapadékmennyiség és az egyedszám között negatív korreláció áll fenn. A novemberi csapadék gátolja az egyedszám-növekedést. A főkomponenssel bővített modell eredménye alapján az egyedszáma és a májusi minimumhőmérséklet, illetve az előző évi december végi csapadék értékek között pozitív korreláció áll fenn. Az enyhe májusi minimumhőmérséklet értékei pozitív hatással lehetnek a lárvák fejlődésére is, elősegítve az egyedszám növekedését. A december második felében hulló csapadék következtében tehát az egyedszám-növekedése valószínűsíthető.

Itt jegyezném meg, hogy eredményeim részben megegyeznek Leskó és munkatársai (1998), valamint Szentkirályi és munkatársai (1998) eredményeivel, miszerint a téli araszolók egyedszáma a meleg-aszályos évben növekszik. Vizsgálatom során ezen állítás az egyes meteorológiai tényezők hatásának időpontjaival kiegészítésre kerültek.

\section{B, A téli araszolókon kívül a „nyári araszolók” fejlődése a tavaszi, legfőképp a márciusi és áprilisi klimatikus elemektől függ:}

A gyakori apróaraszolóval (I. dimidiata) a klímaindikátorokkal bővített modell eredményével kapcsolatban arra a megállapításra jutottam, hogy az egyedszámokkal szignifikáns pozitív korrelációt mutat a március végi csapadék mennyisége, tehát a csapadékos március vége egyedszám-növekedést eredményez. Az előző év június hónap végének minimumhőmérséklete negatív korrelációt mutat, azaz a júniusi meleg éjszakák gátolják az egyedszám-növekedést. Az előző évi január eleji minimum hőmérséklet negatív korrelációt mutat, azaz gátolja az egyedszám-növekedést. Magyarázatot találtam a faj populációjának 1980 és 1990 közötti eredményesebb elszaporodására is. A faj egyedszámának sikerességét az adatok tükrében a bőséges márciusi csapadék eredményezhette, amely pozitív korrelációt mutat az egyedszám növekedésével. A főkomponensekkel bővített modell eredményeképp megállapítottam, hogy a szeptember közepén hulló csapadék elősegíti az egyedszám-növekedést. Az előző év áprilisi minimumhőmérséklet pozitív korrelációt mutat, növekedést eredményezhet az egyedszámban. Továbbá megállapítottam, hogy az előző év október végi-november eleji maximumhőmérsékletek pozitív korrelációt mutatnak az egyedszámmal, ugyanis a novemberig tartó pete stádium végén az enyhe időjárás elősegíti a még ki nem kelt lárvák kikelését. A 
márciusi, a bábozódás idejére eső csapadékparaméter az egyedszámmal pozitív korrelációt mutat. A március végi csapadék meleg tavasz esetén felgyorsíthatja a bebábozódást, viszont a túl sok csapadék a hernyóval együtt a tápnövényt is elpusztíthatja. Szárazság esetében lelassul a hernyó bebábozódása. Az előző évi június végi meleg minimumhőmérséklet kedvezőtlen az előző generáció imágóinak kikelésének, ami a következő évi egyedszámban is megmutatkozhat, ugyanis az előző évi júniusi minimumhőmérséklet és az egyedszám között negatív korreláció van.

A feketepettyes araszoló ( $S$. nigropunctata) a klímaindikátorral bővített modell eredményeiből az a következtetés vonható le, hogy ez a lepke klimatikus szempontból hazánkban érzi jól magát, elterjedési területének nem a szélén, hanem a számára optimális, a nagy mértékben kedvező körülményeket és életfeltételeket nyújtó részén él. Rajzása függ a bábozódási időszakot közvetlen megelőző február végi csapadék paramétertől. Az egyedszám negatív korrelációban van a februári csapadék, az előző év júniusi, szeptemberi és november első felének minimumhőmérsékletével, így ezen paraméterek emelkedése gátolja az egyedszám-növekedést. A szeptember eleji alacsony minimumhőmérséklet véget vethet a rajzásnak. Az előző év őszi időjárása, pontosabban az augusztus végi-szeptember eleji minimumhőmérséklet és a november eleji minimumhőmérséklet is befolyásolja ennek a nedvességkedvelő fajnak a fejlődését, hiszen a meleg, szárazabb időjárás a hernyók pusztulásához vezethet. A S. nigropunctata esetében szignifikáns negatív kapcsolatot mutattam ki az egyedszám és a november eleji minimumhőmérsékletek átlaga között. A főkomponenssel bővített modell esetében magállapítottam, hogy a szeptember eleji magas minimumhőmérséklet szignifikánsan csökkenti az egyedszámot.

A nagy tarkaaraszoló ( $P$. comitata) klímaindikátorokkal bővített modell eredménye alapján a júniusi rajzás függhet az áttelelő báb diapauzája alatti áprilisi csapadék paraméterétől, valamint az előző és vizsgált évi április közepi minimumhőmérsékletektől. E három paraméter és az egyedszám között negatív korreláció van. A csapadék érkezése előbbre, illetve későbbre tolhatja az imágó kikelését. Ez a faj bábként telel, esetenként kétszer is, ugyanis ha nincs elegendő tavaszi csapadék, akkor a bábból nem kelnek ki a lepkék, ám a nagy mennyiségű csapadék sem kedvez nekik. A megfelelő csapadék, ha meg van hozzá a megfelelö hőmérséklet, előbbre is hozhatja a kikelést. Az augusztusi maximumhőmérséklet, illetve a csapadék és az egyedszám között negatív korreláció van. Az előző év augusztusi időjárása is befolyásolja e faj fejlődését, ugyanis, ha az augusztus száraz, a hernyó táplálékául szolgáló gyomvegetáció elszárad, ennek következtében a félkultur környezetben nincs tápláléka a hernyónak, így elpusztul. Az áprilisi 
időjárás szignifikánsan meghatározza ennek a fajnak az egyedszámát, a hőmérséklet emelkedése nem növeli az egyedszámot. A fökomponensekkel bővített modellel eredményéből beláttuk, hogy az alacsony január végi és március végi minimumhőmérséklet nem gátolja az egyedszámnövekedést.

Míg a sárga galajaraszoló (E. pyraliata) a klímaindikátorokkal bővített modell vizsgálata esetén megállapítottam, hogy a faj populációit a hőmérséklet kevésbé befolyásolja viszont a január végi, március végi és november végi - december eleji bőséges csapadék szignifikáns egyedszámnövekedést eredményez. A fökomponensekkel bővített modell eredményeképpen elmondható, hogy mind az áprilisi csapadék, mind az áprilisi minimumhőmérsékletek csökkenése elősegíti az egyedszám-növekedését, azaz közöttük negatív korreláció áll fenn. A májusi lárvák kikelését megelőzően jelentkező hüvös előnyös számukra, egyedszámuk a tavaszi és az előző év tavaszának maximum hőmérsékletével negatív korrelációban áll. A rajzás pedig a június eleji legmagasabb hőmérséklettel hozható összefüggésbe, az egyedszámmal pozitív korrelációban áll. Az őszi minimum hőmérséklet az egyedszámmal negatív korrelációban van. A melegebb ősz peték kiszáradását eredményezhetik, ami a majd kikelő lepkék egyedszámát csökkenti.

Vizsgálataimban egyértelműen igazolható volt, hogy mind a csapadék, mind a hőmérsékleti minimum/maximum értékek szignifikáns kapcsolatot mutattak a rajzással, illetve a lepkék különböző fejlődési szakaszaival. Munkám eredményeként, közel dekádokra bontható pontossággal meghatározhatók azok az időjárási paraméterek, amelyek befolyásolhatják a fajok fejlődését, s ez az információ főleg a kártevők elleni védekezésben fontos.

Brit fénycsapda-adatok vizsgálatával, a lepkék több mint 30 éves fogási értékei alapján Pollard és munkatársai (1995) arra a következtetésre jutottak, hogy a nyári hónapok hőmérsékletének emelkedése egyedszám növekedést eredményezett. Roy és munkatársai (2001) is hasonló eredményre jutottak vizsgálatuk során, ahol 31 vizsgált lepkefajból 28 fajnál növelte a meleg nyár az egyedszámot. Kiváltképp akkor, amikor a vizsgált év száraz, de az azt megelőző év csapadékos volt.

Ehhez részben hasonló eredményekre jutott hazánkban Csóka (1996) is: az 1990-es évek elején az aszályok gyakorisága és mértékének nagysága kiemelkedő szerepet játszott több erdei rovarfaj szokatlan mértékü tömegszaporodásában, hiszen a száraz tél és tavasz által a mortalitási érték jelentősen lecsökkent. Hazai erdészeti kutatások során Leskó és munkatársai (1999) az $O$. brumata hosszú távú (1962-1997) populáció-fluktuációinak elemzése alapján megállapították, hogy a kis téliaraszoló gradációinak kitörését a száraz, aszályos klímájú évek elősegítik. 
Szentkirályi és munkatársai (1998) hosszú távú fénycsapdás elemzésükben lineáris autoregressziós modell segítségével kimutatták (az általam is vizsgált) O. brumata, E. defoliaria, C. pennaria, E. aurantiaria lepkefajok populációszintjét az aszályos évek megnövelik. Leskó és munkatársai (1998b) egy, ugyanezen fajokat érintő, de nem az egyes fajok populációszintjét, hanem az araszoló együttesekre vonatkozó vizsgálat során azt a konklúziót vonták le, miszerint az araszolók populáció-növekedésében, gradációik kialakulásában meghatározó szerepet játszanak az aszályos évek. Míg más irodalomban (Pollard et al., 1997) egyes lepkéknél a szaporodási siker aszályos időjárás általi csökkenéséről olvashatunk.

Negatív populáciodinamikai változásokról is beszámol több kutató:

Roy és munkatársai (2001) a Pieris brassicae regressziós modellezése szerint a nyarak melegedésével kapcsolatban egyedszám csökkenést prognosztizálnak. Amerikai megfigyelések alapján (Roberts et al., 1993, Gray, 1994) a Lymantria dispar populációi összeomlanak azon évek után, ahol a téli meleg napok száma magas volt. A Brit-szigeteken az Arctia caja 30 éves populációdinamikáját vizsgálva 28\%-os egyedszám-csökkenést állapítottak meg (Conrad et al., 2002). Conrad és munkatársai $(2004,2006)$ közel 30 éves adatsorok elemzése során, a több mint 330 lepkefaj mintegy felének csökkent az egyedszáma (71\%-nappali, 66\%-éjjeli), míg erős egyedszám emelkedést csak 6 fajnál tapasztaltak. Salama és munkatársai (2007) 35 évnyi skóciai fogási adatokat elemezve négy vizsgált fajból három nyáron rajzó fajnak az egyedszáma nőtt, míg az ősszel rajzó faj egyedszámában nem tapasztaltak változás.

A dolgozatomban a klímaindikátorok matematikai elvek alapján kerültek kialakításra. A modellbe beillesztett indikátorok föként a lárvák aktivitási periódusában és az imágók rajzásakor mért hőmérsékleti és csapadék értékekből kialakított mutatók közül kerültek ki. Vizsgálatom során több olyan eredmény is született miszerint meghatározó szerepe lehet az előző nemzedék lárvakori időszakának meteorológiai tényezőinek az egyedszámok alakulásában. Ennek a jelenségnek az okát jelenlegi kutatásaim alapján nem tudom megmagyarázni, ezért további vizsgálatokat tartok szükségesnek és folytatni kívánom az erre irányuló kutatásokat a kérdés tisztázása érdekében.

A fent „nyári araszolók”-ként leírt fajokat (nem kártevő fajok) nem vizsgálták populációdinamikai vonatkozásban, így valószínüleg ezek az első adatok ezekre a lepkékre nézve. A magyar szakirodalomban ezekre a fajokra (E. pyraliata, P. comitata, I. dimidiata, S. nigropunctata) semmilyen érdemleges feljegyzés sincs, amely a klimatikus tényezőkkel foglalkozna. 
A RegCM3.1 regionális klímamodell becslései alapján kiszámoltam a klímaindikátorok értékeit. Arra voltam kíváncsi, hogy milyen változást becsül a modell a 2021-2050-es és a 20712100-as időszakokra az 1961-1990-es időszakot tekintve referenciának. Az alapmodellek, az indikátorral bővített modellek, valamint a főkomponensekkel bővített modellek a klimatikus indikátorok jövőbeli változását a RegCM3.1 regionális klímamodell becslései szerint figyelembe véve a fajok egyedszámának becsült minimum és maximum értékeire az alábbi prognózisokat eredményezték:

Operophtera brumata: Rövidtávon a jövőben (2021-2050) az minimális egyedszámok emelkedésére számíthatunk. Hosszútávon (2071-2100) azonban csökkenést várhatunk. A modell egyedszám-becsléseinek maximum értékeit tekintve, a 2021-2050 intervallumra vonatkozó becslések az 1961-1990-es referencia-időszakhoz képest emelkedést, a 2071-2100-as időszakra vonatkozóan pedig további szignifikáns emelkedést jeleznek.

Erannis defoliaria: A faj egyedszámának becsült minimum és maximum értékei is szignifikáns csökkenést vetítenek előre mind a 2021-2050-es, mind pedig a 2071-2100-as időszeletre vonatkozóan.

Colotois pennaria: A modell által becsült egyedszámok minimumait időszeletenként összehasonlítva a referencia időszakhoz (1961-1990) képest rövidtávon némi emelkedést becsülhetünk, de hosszabb távon (2071-2100) jelentősebb egyedszám-csökkenést jósol a modell. A modell egyedszám-becsléseinek maximum értékeit vizsgálva is csökkenés várható.

Erannis aurantiaria: A faj becsült egyedszám-értékeinek minimuma rövidtávon emelkedik, de hosszabb távon a csapadék indikátor értékének változása az egyedszám visszaeséséhez vezethet. A becsült egyedszámok minimum és maximum értékeit összehasonlítva a különböző időszeletekkel elmondhatjuk, hogy a bővített modell becslései alapján adott induló egyedszám mellett a 2071-2100-as időszelet esetben alacsonyabb becsült egyedszám várható, bár rövidtávon (2021-2050) kisebb ütemü növekedést tapasztalhatunk.

Idaea dimidiata: A becsült egyedszám minimum értékét tekintve a különböző időszeleteket összehasonlítjuk, megállapíthatjuk, hogy 1961-1990-től 2071-2100 időszelet irányában az egyedszám egyre kevésbé emelkedik adott induló egyedszám mellett. A modell egyedszámbecsléseinek maximum értékeit vizsgálva egyedszám-csökkenést várhatunk 2021-2050-ig, valamint a 2071 és 2100 közötti időszakra is. Az időszeleteket összehasonlítva a távoli jövő felé egyre csökken az egyedszámok növekedésének mértéke.

Scopula nigropunctata: A becsült egyedszám minimum értékét tekintve, rövidtávon a 20212050-es időszeletben 400 kiinduló egyedszámig a faj következő évi egyedszáma nőhet, ezután viszont csökkenhet. A 2071-2100-as időszeletnél mindez a változás már 350 kiinduló egyedszámnál kialakulhat. A modell egyedszám-becsléseinek maximum értékeit nézve 
rövidtávon elmondható, hogy 1300 kiinduló egyedszámig a faj következő évi egyedszáma magasabb, s ezután alacsonyabb. A 2071-2100-as időszeletnél mindez az egyedszám-növekedés már 800 kiinduló egyedszámnál előkezdődhet. Mindent egybevetve mind a közel-, mind pedig a távolabbi jövő is hátrányosan érinti ezt a fajt.

Pelugra comitata: A modell egyedszám-becslésének minimum értékeit elemezve rövidtávon az egyedszám-csökkenést várhatunk, majd 2071-2100 időszakban az előzőhöz viszonyítva kismértékben növekedhet. Az egyedszám változást tekintve mindegyik időszeletre elmondható, 100 kiindulási egyedszám értékig a modell a következő évre egyedszám-növekedést becsül. A modell egyedszám-becsléseinek maximum értékeit nézve elmondhatom, hogy a 2021-2050-es idősort az egyedszám-csökkenés, s 2071-2100 időszakot a stagnálás jellemezheti.

Eulithis pyraliata: A becsült egyedszám értékét nézve mindegyik időszeletre elmondható, az egyedszám minimuma a következő időszakra várhatóan csökken. A modell egyedszámbecsléseinek maximum értékeit tekintjük, az egyedszám értéke nőhet mind a két vizsgált 20212050-es és a 2071-2100-as jövőbeli időszeletre vonatkozóan.

Tehát a klímamodell adott időjárás és klímatényezők 30-30 évre vonatkozó becslése szerint a becsült egyedszámok értékei alapján rövidtávon az O. brumata, C. pennaria, E. aurantiaria és az $E$. pyraliata esetében várható egyedszám-növekedés, míg $E$. defoliaria és $P$. comitata esetében egyedszám-csökkenésre számíthatunk. Hosszútávon egyedszám-csökkenés prognosztizálható az Erannis fajok esetében, míg egyedszám-növekedés az E. pyraliata esetében. A $S$. nigropunctata, $P$. comitata és $I$. dimidiata esetében szignifikáns változás nem várható, tehát e fajok populációjának alakulását hosszú távon várhatóan nem befolyásolja jelentősen a klímaváltozás. A vizsgált fajok közül valószínűleg csupán egy fajnak lesz előnyös a klímaváltozás, azaz várhatóan kedvezni fog a jövő az E. pyraliata-nak. Ezzel ellentétben a változások várhatóan kedvezőtlenül érintik az E. aurantiaria fajt, de a modellünk becslése alapján meg fogják sínyleni a klíma változását és $C$. pennaria fajok egyedei is. 


\section{7. ÖSSZEFOGLALÁS}

A XXI. század legnagyobb kihívása a klímaváltozás. A magyarországi éghajlat tendenciái és a valószínüsíthető változások egyaránt a hőmérséklet- és csapadékviszonyok várható kedvezőtlen változására hívják fel a figyelmet.

A különböző rovarfajok rajzásának ideje és időtartama eltérő, ezért az állandóan változó környezeti hatások különböző módon befolyásolják a rovarok repülését. A rovarok repülési aktivitását számos más abiotikus tényező mellett, az időjárás, ezen belül legfőképpen a hőmérséklet és a csapadék befolyásolja. Az araszolólepkék populációdinamikai vizsgálatainak a feljegyzett kártételek alapján kiemelt jelentősége van a növényvédelemben mind az erdők, mind pedig a gyümölcsfák védelmének kutatásai terén.

A vizsgálathoz az Országos Erdészeti Fénycsapdahálózat gyüjtési eredményeiből az 1962 és 2000 közötti, nyolc araszolólepke rajzási adatait használtam. Vizsgálatom a rajzáskezdet és a rajzáshossz közti összefüggéseket, valamint ezek időbeli változását regressziós modellekkel írtam le.

Az egynemzedékes araszoló lepkefajok populációdinamikai habitusának leírását differenciaegyenleten alapuló populációdinamikai modellezéssel végeztem, s ezután az OMSZ megfigyelt napi adataiból a rovar fenológiai fázisaitól függő klimatikus igényeinek megfelelően az egyedszámmal magas korrelációban álló klimatikus indikátorokat definiáltam, melyek lineáris kombinációit additív tényezőként illesztettem a modellbe. A modelleket az indikátorokból képzett főkomponesekkel mint additív tényezőkkel való bővítésével fejlesztettem. A kutatásba bevont lepkék 40 éves adatsorát elemezve fajspecifikus megállapításokat tettem az egyedszámnak a klimatikus indikátoroktól függő változásaira.

A modelleket a RegCM3.1 regionális klímamodell becslésével is futtattam az 1961-1990es referenciaidőszakra, valamint a 2021-2050, illetve a 2071-2100 prognózisokra vonatkozóan. A kapott eredményeket statisztikai módszerekkel összehasonlítottam, és ez alapján elemeztem a jövőben várható változásokat a vizsgált fajtákra vonatkozóan.

Az eredmények a növényvédelmi prognosztika számára is fontosak lehetnek a kártevők elleni védekezésben, de a kutatás további folytatásának lehetőségeként ezen modelleket a továbbiakban védett vagy ritka, valamint kártevő lepkék, rovarok populációdinamikai karakterének, illetve ezek jövőbeli várható változásának feltárására is alkalmazhatjuk. 


\section{SUMMARY}

Climate change is the greatest challenge in the 21 st century. Both the tendencies of climate of Hungary and the probable changes are calling attention to the unfavourable changes of temperature and rainfall relations.

The time and period of swarming of different insects are divergent, thus the constantly changing environmental effects influence the flight of insects in a different way. The flight activity of insects is influenced by numerous other abiotic facts, mainly by the weather depending first of all on the temperature and precipitation. According to the recorded damage, the population dynamic inspection of geometrid moths is significantly important in plant protection, that is, in the research field of protection of forests and fruit trees.

As for the investigation, we used the swarming data of eight geometrid moths from the collected results from 1962 to 2000 of Hungarian Forestry Light Trap Network. We also examined the connection between the beginning and length of swarming as well as the temporal changes of these that were described by regression models.

The description of population dynamic habit of univoltine geometrid moths was made by population dynamic modelling based on differential equations. Then from the observed daily data of the Hungarian Meteorological Service (OMSZ), in accordance to the climatic demands of the insects depending on its phenology phases, we defined climatic indicators with high correlation to the abundance. The climatic indicators were integrated into the model as additive factors. The models were developed further by additive factors of independent linear combinations of the climatic indicators created by principal component analysis. As a result of the analysis of the 40-year-long data of the moths involved in the research, we have made specific findings about the occurred changes of abundance due to climatic indicators.

The models were then run by the estimations of regional climate model RegCM3.1 of the reference period 1961-1990, moreover of the future time intervals 2021-2050 and 2071-2100. We compared the results statistically and analysed the predictable changes in the future relating to species.

Our results can serve as important information in pest control of plant protection. There are several remained directions to further studies both towards specification and generalization sense. These developed models are useful tools in the characterisation of population dynamics of other insects as well with the aim to learn future expectations and manage climate dependent risk. 


\section{KÖSZÖNETNYILVÁNÍTÁS}

Ezúton szeretnék köszönetet mondani mindazon személyeknek, szervezeteknek és intézményeknek, akik hozzájárultak disszertációm elkészítéséhez, valamint köszönettel tartozom mindazoknak, akik a dolgozat elkészítését megelőző kutatómunkám során segítségemre voltak.

Első helyen hálás tisztelettel szeretném megköszönni témavezetőmnek, Dr. Ladányi Mártának, hogy szárnyai alá vett, s munkámat mindvégig figyelemmel kísérte, egyengette és maximálisan segítette. Köszönöm emberi és szakmai támogatását, tanácsait, a belém vetett bizalmát és türelmét.

Tisztelettel szeretném megköszönni Dr. Mészáros Zoltán professzor úrnak, hogy doktori munkámat messzemenőkig támogatta, segített a fajok kiválasztásánál és értékes szakmai tanácsaival kutatói pályafutásom kezdete óta mindvégig támogatott.

Köszönettel tartozom a tanszék egykori vezetőjének, Harnos Zsolt (†) akadémikus úrnak támogatásáért és bizalmáért, továbbá Dr. Hufnagel Leventének önzetlen segítségéért és matematikai statisztikai útmutatásaiért.

Dr. Puskás Jánosnak, aki kezdetben irányt mutatott tudományos érdeklődésemnek, majd doktori tanulmányaim és disszertációm készítése során mindvégig mederben tartotta gondolataimat, valamint, hogy átsegített a dolgozat írása közben adódó nehézségeimen.

Köszönöm Dr. Nowinszky Lászlónak, hogy a szombathelyi kutatómühely keretein belül segítette tudományos munkámat.

Köszönetet mondok Dr. Csóka Györgynek, Dr. Hirka Anikónak, Szabóky Csabának és az ERTI további munkatársainak, a dolgozathoz nélkülözhetetlen adatokért, valamint a Fóti Boglárka Alapítványnak, Petrányi Gergőnek, Rébányai-Reser Lászlónak, Fazekas Imrének a lepkékkel kapcsolatos szakmai segítségért.

Köszönöm a BCE KeTK Biometria és Agrárinformatikai Tanszék munkatársainak, hogy segítségükkel, észrevételeikkel elősegítették a dolgozatom kialakítását.

Hálával tartozom szüleimnek $(\dagger)$ a belém vetett bizalmukért és korai halálukig tartó biztatásukért, valamint egykori szomszédunknak, Dr. Bozai Józsefnek (†), hogy bevezetett a fénycsapdázás rejtelmeibe Becehegyen.

Végezetül hálásan köszönöm Telerovszky Valériának és Boncsér Erzsébetnek, hogy a doktori képzésem alatt maximális segítséget nyújtottak mindennemü adminisztratív, dokumentációs és pályázati ügyben.

A munkámat a Jedlik Ányos Ösztöndíj támogatta. A disszertációmmal kapcsolatos kutatásokat a TÁMOP-4.2.4.A/2-11/1-2012-0001 azonosító számú Nemzeti Kiválóság Program - Hazai hallgatói, illetve kutatói személyi támogatást biztosító rendszer kidolgozása és müködtetése konvergencia program címü kiemelt projekt keretében zajlott. A projekt az Európai Unió támogatásával, az Európai Szociális Alap társfinanszírozásával valósul meg. 


\section{IRODALOMJEGYZÉK}

[1] Adem, J. (1965): Experiments aiming at monthly and seasonal numerical weather prediction. Monthly Weather Review, 93: 495-503.

[2] Aukema, B.H., Werner, R.A., Haberkern, K.E, Illman, B.L., Clayton, M.K., Raffa, K.F. (2006): Quantifying sources of variation and frequency of fungi associated with spruce beetles: Implications for hypothesis testing and sampling methodology in bark beetle-symbiont relationships. Forest Ecology and Management, 217: 187-202.

[3] Ayres, M.P., Lombardero, M.J. (2000): Assessing the consequences of global change for forest disturbance from herbivores and pathogens. The Science of The Total Evironment, 262(3): 263-286.

[4] Bartholy J., Csima G., Horányi A., Hunyady A., Pieczka I., Pongrácz R., Torma Cs., Szépszó G. (2009b): Regional climate models for the Carpathian basin: validation and preliminary results for the future. EGU2009-12509. Geophysical Research Abstarct, 11, 12509. CD-ROM. EGU General Assembly 2009.

[5] Bartholy J., Pongrácz R., Torma Cs. (2010): A Kárpát-medencében 2021-2050-re várható regionális éghajlatváltozás RegCM-szimulációk alapján. „KLÍMA-21” Füzetek, 60: 3-13.

[6] Bartholy J., Pongrácz R., Torma Cs., Hunyady A. (2006a): A regionális klímaváltozás becslése a Kárpát-medence térségére. VAHAVA-zárókonferencia. In: LÁNG I., JOLÁNKAI M., CSETE L. (szerk.): A globális klímaváltozás: hazai hatások és válaszok. KvVM-MTA “VAHAVA” project. Budapest. Akaprint CD-ROM. 5.

[7] Bartholy J., Pongrácz R., Torma Cs., Hunyady A. (2006b): A PRECIS regionális klímamodell és adaptálása az ELTE Meteorológiai Tanszékén. In: WEIDINGER T. (szerk.): XXXI. Meteorológiai Tudományos Napok - Az éghajlat regionális módosulásának objektív becslését megalapozó klímadinamikai kutatások. Budapest: Országos Meteorológiai Szolgálat, 99-114.

[8] Bartholy J., Pongrácz R., Torma Cs., Pieczka I., Kardos P., Hunyady A. (2009a): Analysis of regional climate change modelling experiments for the Carpathian basin. International Journal of Global Warming, 1(1-2-3): 238-252.

[9] Bazykin, A.D., Berezovskaya, F.S., Isaev, A.S., Khlebopros, R.G. (1997): Dynamics of Forest Insect Density: Bifurcation Approach. Journal of Theoretical. Biology, 186(3): 267-278.

[10] Bergmann, A. (1955): Die Grosschmetterlinge Mitterdeutschlands. Band 5/1. Spanner. Jena, Urania-Verlag GmbH. 483. 
[11] Berryman, A.A. (1999): Principles of population dynamics and their application. Stanley Thornes Publishers, Cheltenham, UK

[12] Bianchi, F.J., Werf, J.A., van der W. (2004): Model evaluation of the function of prey in non-crop habitats for biological control by ladybeetles in agricultural landscapes. Ecological Modelling, 171(1-2): 177-193.

[13] Bjørnstad, O.N., Peltonen, M., Liebhold, A.M., Baltensweiler, W. (2002): Waves of larch budmoth outbreaks in the European Alps. Science, 298(5595): 1020-1023.

[14] Bognár S., Huzián L. (1979): Növényvédelmi állattan. Budapest, Mezőgazdasági Kiadó. 557. ISBN: 963-230-074-2

[15] Borhidi A. (2004): Az éghajlatváltozás biológiai és társadalmi hatásairól. Forrás: http://mta.hu/data/cikk/12/69/41/cikk_126941/10._Okologia,_biodiverzitas,_kornyez etvedelem/Eghajlatvaltozas.pdf. [Letöltve: 2012. október 2. ]

[16] Brandts, W.A.M., Longtin, A., Trainor, L.E.H. (2001): Two-category Model of Task Allocation with Application to Ant Societies. Bulletin of Matematical Biology, 63(6): 1125-1161.

[17] Buse, A., Dury, S.J., Woodburn, R.J.W., Perrins, C.M., Good, J.E.G. (1999): Effects of elevated temperature on multi-species interactions: the case of Pedunculate Oak, Winter Moth and Tits. FunctionalEcology, 13(1): 74-82.

[18] Buse, A., Good, J.E.G. (1996): Synchronization of larval emergence in winter moth (Operophtera brumata L.) and budburst in pedunculate oak (Quercus robur L.) under simulated climate change. Ecological Entomology, 21: 335-343.

[19] Buse, A., Good, J.E.G., Dury, S.J., Perrins, C.M. (1998): Effects of elevated temperature and carbon dioxid on the nutritional quality of leaves of oak (Quercus robur L.) as food for the winter moth (Operophtera brumata L.). Functional Ecology, 12: 742749.

[20] Bylund, H. (1999): Climate and the population dynamics of two insect outbreak species int he north. Ecology Bull. 47: 54-62.

[21] Čamprag, D. (2011). Impact of climate to appearance of field crop pests in Vojvodina [Serbia] during 2001-2020 [ie 2010]. Plant Doctor, 39(4): 425-433.

[22] Cannell, M.G.R., Grace, J., Booth, A. (1989): Possible impacts of climatic warming on trees and forests in the United Kingdom: A review. Forestry, 62: 337-364.

[23] Castañera, M.B., Aparicio, J.P., Gürtler, R.E., (2003): A stage-structured stochastic model of the population dynamics of Triatoma infestans, the main vector of Chagas disease. Ecological Modelling, 162(1-2): 33-53. 
[24] Collins, W.D., Bitz, C.M., Blackmon, M.L. et al. (2006): The Community Climate System Model Version 3 (CCSM3). Journal of. Climate, 19(11): 2122-2143.

[25] Conrad, K.F. Warren, M.S., Fox, R., Parson, M., Woiwod, I.P. (2006): Rapid declines of common widespread British moths provide evidence of an insect biodiversity crisis. Biological Conservation, 132: 279-291.

[26] Conrad, K.F., Woiwod, I.P., Parson, M., Fox, R., Warren, M.S. (2004): Long-term population ternds in widespread British moths. Journal of Insect Conservation, 8: 119-136.

[27] Conrad, K.F., Woiwod, I.P., Perry, J. N., (2002): Long-term decline in abundance and dsitribution of the garden tiger moth (Arctia caja) in Great Britain. Biological Conservation, 106: 329-337.

[28] Coops, N.C., Waring, R.H., Law, B.E. (2005): Assessing the past and future distribution and productivity of ponderosa pine in the Pacific Northwest using a process model, 3-PG. Ecological Modelling, 183(1): 107-124.

[29] Cooter; E.J. (1990): The Impact of Climate Change on Continuous Corn Production in the Southern USA. Climate Change, 16: 53-82.

[30] Cormont, A., Jochem, R., Malinowska, A.H., Verboom, J., Wallis deVries, M.F., Opdam, P.F.M. (2012): Can phenological shifts compensate for adverse effects of climate change on butterfly metapopulation viability? Ecological Modelling, 227: 72-81.

[31] Crozier, L., Dwyer, G. (2006): Combining Population Dynamic and Ecophysiological Models to Predict Climate-Induced Insect Range Shifts. The American Naturalist, 167(6): 853-866.

[32] Czúcz B., Kröel-Dulay Gy., Rédei T., Botta-Dukát Z., Molnár Zs. (2007): Éghajlatváltozás és biológiai sokféleség. Kutatási jelentés. MTA ÖBKI. 278.

[33] Csima G., Horányi, A. (2008): Validation of the ALADIN-Climate regional climate model at the Hungarian Meteorological Service. Idöjárás, 112: 155-177.

[34] Csóka Gy. (1994): Hernyókárok a magyarországi tölgyesekben 1961-1993 között. Növényvédelem, 30(6): 263-268.

[35] Csóka Gy. (1995): Increasing damage trend of some forest insect in Hungary: an indication of climate changes? IUFRO XX. World Congress Abstracts of Invited Papers: 181-182.

[36] Csóka Gy. (1995): Lepkehernyók. Budapest. Agroinform Kiadó és Nyomda Kft. 151. ISBN: 963-502-614-5

[37] Csóka Gy. (1996): Aszályos évek - fokozódó rovarkárok erdeinkben. Növényvédelem, 32(11): 545-551. 
[38] Csóka Gy. (2006): Aszályos évek - fokozódó rovarkárok erdeinkben. Növényvédelem, 32(11): 545-551.

[39] Csóka Gy., Hirka, A. (2009): Gyapjaslepke (Lymantria dispar L.) legutóbbi tömegszaporodása Magyarországon. Növényvédelem, 45(4): 196-201.

[40] de Wit, C.T., Goudriaan, J. (1974): Simulation of Ecological Processes. Simulation Monographs 4. PUDOC, Wageningen. 175.

[41] de Wit, C.T., van Keulen, H. (1972): Simulation of transport processes in Soils. Simulation Monographs 1. PUDOC, Wageningen. 100.

[42] Dennis, R.L.H., Shreeve, T.G. (1991): Climatic change and the British butterfly fauna: opportunities and constraints. Biology Conservation, 55: 1-16.

[43] Devictor, V., Swaay, C.V., Brereton, T. et al. (2012): Differences in the climatic debts of birds and butterflies at a continental scale. Nature Climate Change, 2: 121-124. http://www.nature.com/nclimate/journal/v2/n2/full/nclimate1347.html

[44] Di Pasquale, C, Jacobi C.M. (1998): Dynamics of pollination: A model of insectmediated pollen transfer in self-incompatible plants. Ecological Modelling, 109(1): 25-34.

[45] Dickinson, R.E., Errico, R.M., Giorgi, F., Bates, G.T. (1989): A regional climate model for the western United States. Climatic Change, 15: 383-422.

[46] Dufresne, J.-L., Friedlingstein, P., Berthelot, M., Bopp, L., Ciais, P., Fairhead, L., Le Treut, H., Monfray, P. (2002): On the magnitude of positive feedback between future climate change and the carbon cycle. Geophysical Research Letters, 29(14), 10.1029/2001GL013777,

[47] Dury, S.J., Good, J.E.G., Perrins, C.M., Buse, A., Kaye, T. (1998): The effects of increasing $\mathrm{CO} 2$ and temperature on oak leaf palatability and the implications for herbivorous insects. Global Change Biology, 4: 55-62.

[48] Ellis, W.N, Donner, J.H, Kuchlein, J.H. (1997): Recent shifts in phenology of Microlepidoptera, related to climatic change (Lepidoptera). Entomologische Berichten (Amsterdam), 57: 66-72.

[49] EU Green Paper (2007): Green Paper from the commission to the council, the European Parliament, the European Economic and Social committee and the committee of the Regions - adapting to climate change in Europe - options for eu action. Commission of the European Communities http://eur-lex.europa.eu/LexUriServ/site/en/com/2007/ com2007_0354en01.pdf

[50] Fajčik, J. (2003): Die Schmetterlinge Mittel- und Nordeuropas, Bratislava, ER-PRINT, 172. ISBN: 80-968566-3-4 
[51] FAO (2006): Livestock's Long Shadow - Environmental Issues and Options. ftp://ftp.fao.org/docrep/fao/010/a0701e/a0701e00.pdf (PDF)

[52] Farrow, R.A. (1991): Implications of potential global warming on agricultural pests in Australia. EPPO Bulletin, 21: 683-696.

[53] Ferenczy A., Eppich B., Varga R.D., Bíró I., Kovács A., Petrányi G., Hirka A., Szabóki Cs., Isépy I., Priszter Sz., Türei D., Gimesi L., Garamvölgyi Á., Homoródi R., Hufnagel L. (2010): Comparative analysis of the relationship between phenological phenomena and meteorological indicators based on insect and plant monitoring. Applied Ecology and Environmental Research 8(4): 367-376.

[54] Flinn, P.W., Hagstrum, D.W., Reed, C., Phillips, T.W. (2004): Simulation model of Rhyzopertha dominica population dinamics in concrete gran bins. Journal of Stored Products Research, 40(1): 39-45.

[55] Foley, J.A., Prentice, I.C., Ramankutty, N., Levis, S., Pollard, D., Sitch, S., Haxeltine, A. (1996): An integrated biosphere model of land surface processes, terrestrial carbon balance, and vegetation dynamics. Global Biogeochemical Cycles, 10: 603-628.

[56] Forister, M.L., Shapiro, A.M. (2003): Climatic trends and advancing spring flight of butterfl ies in lowland California. Global Change Biology, 9(7): 1130-1135.

[57] Forrest, J., Miller-Rushing, A.J. (2010): Toward a synthetic understanding of the role of phenology in ecology and evolution. Philosophical Transactions of the Royal Society B-Biological Sciences, 365(1555): 3101-3112.

[58] Friedlingstein, P., Dufresne, J.-L. Cox, P.M., Rayner, P. (2003): How positive is the feedback between climate change and the carbon cycle? Tellus B, 55(2): 692-700.

[59] Fry, C. (2008): A klímaváltozás. Budapest, Totem Plusz Könyvkiadó. 208. ISBN: 9635903542

[60] Führer E., Mátyás Cs. (2005a): A klímaváltozás hatása a hazai erdők szénmegkötő képességére és stabilitására. Magyar Tudomány, 7: 837-840.

[61] Führer E., Mátyás Cs. (2005b): Erdőgazdálkodás és klímabizonytalanság. „,Agro - 21 ” Füzetek, 41: 124-128

[62] Führer E., Mátyás Cs. (2006): A klímaváltozás hatása a hazai erdőtakaróra. „Agro-21” Füzetek, 48: 34-38

[63] Gienapp, P., Hemerik, L., Visser, M.E. (2005): A new statistical tool to predict phenology under climate change scenarios. Global Change Biology, 11(4): 600-606.

[64] Gilpin, M.E., Ayala, F.J. (1973): Global models of growth and competition. Proceedings of the National Academy of Sciences of the United States of America, 70: 3590-3593. 
[65] Gimesi L., Hufnagel L. (2010): The possibilities of biodiversity monitoring based on hungarian light trap networks 1. Applied Ecology and Environmental Research, 8(3): 223-239.

[66] Giorgi, F. (1989): Twodimensional simulations of possible mesoscale effects of nuclear war fires. Journal of Geophysical Research, 94: 1127-1144.

[67] Giorgi, F., Marinucci, M.R., Bates, G.T., Decanio, G. (1993): Development of a second generation regional climate model (RegCM2). Part II: Convective processes and assimilation of lateral boundary Conditions. Monthly Weather Review, 121: 28142832.

[68] Glavendekić, M. (2010): Parasitoids and hyperparasitoids of Erannis defoliaria Cl. (Lepidoptera, Geometridae) in oak forests. Sumarski list br. 7-8. CXXXIV, 403- 410.

[69] Godfray, H.C.J., Briggs, C.J. (1995): The population dynamics of pathogens that control insect outbreaks. Journal of Theoretical Biology, 176(1): 125-136.

[70] Gordon, C., Cooper, C., Senior, C.A., Banks, H., Gregory, J.M., Johns, T.C., Mitchell, J.F.B., Wood, R.A. (2000): "The simulation of SST, sea ice extents and ocean heat transports in a version of the Hadley Centre coupled model without flux adjustments" Climate Dynamics, 16(2-3): 147-168. doi:10.1007/s003820050010 http://www. citeulike.org/user/KarinaWilliams/article/3855412

[71] Gordon, H.B., O’Farrell, S.P., Collier, M.A., Dix, M.R., Rotstayn, L.D., Kowalczyk, E.A., Hirst, A.C., Watterson, I.G. (2010): The CSIRO Mk3.5 Climate Model. Technical Report, The Centre for Australian Weather and Climate Research, 21: 62.

[72] Goudriaan, J. (1977): Crop micrometeorology: a simulation study. Simulation Monographs. Wageningen. Center for Agricultural Publishing and Documentation. 257. ISBN 90-220-06 14-X.

[73] Gray, D.R. (1994): Gypsy moth development - a model of phenological events. PhD dissertacion. Virginia Polytechnic Institute and State University, Blacksburg, VA.

[74] Grodzinski, B., Schmidt, J.M., Watts, B., Taylor, J., Bates, S., Dixon, M.A., Staines, H. (1999): Regulating plant/insect interactions using CO2 enrichment in model ecosystems. Advances in Space Research, 24(3): 281-291.

[75] Gross, P., Hawkins, B.A., Cornell, H.V., Hosmane, B. (2005): Focusing on targets: an alternative approach to the problem of predicting outcomes in classical biological control of insect pests. Basic \& Applied Ecology, 6:571-584.

[76] Győrfi J. (1957): Erdészeti rovartan. Budapest. Akadémiai Kiadó. 670. 
[77] Hagen, S.B., Jepsen, J.U., Ims, R.A., Yoccoz, N.G. (2007): Shifting altitudinal distribution of outbreak zones of winter moth Operophtera brumata in sub-arctic birch forest: a response to recent climate warming? Ecography, 30(2): 299-307.

[78] Harnos Zs., Gaál M., Hufnagel L. (2008): Klímaváltozásról mindenkinek. Budapest, ADUPRINT Kiadó és Nyomda Kft. 199. ISBN:978-963-503-384-3

[79] Harnos Zs., Ladányi M. (2005): Biometria agrártudományi alkalmazásokkal. Budapesti Corvinus Egyetem. Aula Kiadó, Budapest. 335.

[80] Harrington, R.H., Woiwod, I.P. (1995): Insect crop pests and the changing climate. Weather, 50: 200-208.

[81] Harrison, P., Butterfield, R. (1998): Modelling climate change impacts on wheat, grapevine and potato In: Europe. Fifth CLIVARA Workshop Meeting Summary, Florence, Italy, 13-17.

[82] Harrison, P., Butterfield, R.E., Downing, T.E. (eds) (1995): Céimate Change and Agriculture in Europe. Assessment of impacts and adaptation. Reseach Report, 9. Oxford: Environmental Change Unit, University of Oxford. 414.

[83] Harvell, C.D., Mitchell, C.E., Ward, J.R., Altizer, S., Dobson, A.P., Ostfeld, R.S., Samuel, M.D. (2002): Climate warming and disease risks for terrestrial and marine biota. Science, 296: 2158-2162.

[84] Hasumi, H., Emori, S. (eds.) (2004): K-1 Model Developers (2004), K-1 coupled model (MIROC) description, K-1 Technical Report 1. Center for Climate System Research, University of Tokyo, Japan. 34.

[85] Hedden. R.L. (1989): Global climate change: implications for silviculture and pest management. The Station, 74: 555-562.

[86] Heinz, K.M., Nelson, J.M. (1996): Interspecifictions among Natural Enemies of Bemisiain an Inundative Biological Conrol Program. Biological Control, 6(3): 384393.

[87] Hernández-Zul, M.I., Quijano-Carranza, J.A., Yáñez-López, R., Ocampo-Velázquez, R.V., Torres-Pacheco, I., Guevara-González, R.G., Castro-Ramírez, A.E. (2013): Dynamic Simulation Model of Central American Locust Schistocerca piceifrons (Orthoptera: Acrididae). Florida Entomologist, 96(4):1274-1283.

[88] Hickling, R., Roy, D.B., Hill, J.K., Jarvis, A., Thomas, C.D. (2005): A northward shift of range margins in Brithis Odonata. Global Change Biology, 11: 502-506.

[89] Hickling, R., Roy, D.B., Hill, J.K., Fox, R., Thomas, C.D. (2006): The distributions of a wide range of taxonomic groups are expanding polewards. Global Change Biology 12: 450:455. 
[90] Hluchý, M. (1990). Changes in the composition and abundance of selected families of Lepidoptera inhabiting the Pavlovské vrchy Hills during the 20th century. Acta Entomologica Bohemoslovaca, 87(4): 278-289.

[91] Hönisch, B., Aidgwell, A., Schmidt, D.N. et aj. (2012): The Geological Record of Ocean Acidification. Science, 335(6072): 1058-1063.

[92] Hufnagel L., Kúti Zs., Hlaszny E., Reiczigel Zs., Molnár M., Homoródi R., Flórián N., Gergócs V., Türei D., Ladányi M. (2012): A klímaváltozás közösségökológiai hatásának elemzései. 7-24. In: SZENTELEKI, K. és SZILÁGYI, K. (Szerk.): Fenntartható fejlődés, élhető régió, élhető települési táj (3). Budapesti Corvinus Egyetem. 216.

[93] Huzsvai L. (2008): Környezet- és természetvédelem ismeretkörben. www.tankonyvtar.hu letöltve 2012. október 23.

[94] Huzsvai L. (2011): Kutatói pályára felkészítő akadémiai ismereten alapuló tananyagfejlesztés - Környezet- és természetvédelem ismeretkörben. Debreceni Egyetem Agrár- és Gazdálkodástudományok Centruma. www.tankonyvtar.hu/ en/... /0032_kornyezetved_termved_kutatoi.pdf

[95] IPCC (2007): Climate Change 2007: The Physical Science Basis. Contribution of Working Group I to the Fourth Assessment Report of the IPCC. (S. Solomon, D. Qin, M. Manning, Z. Chen, M. Marquis, K.B. Averyt, M. Tignor, H.L. Miller, szerk.) Intergovernmental Panel on Climate Change, Cambridge University Press, Cambridge, UK and New York, NY. 996. (http://www.ippc.ch)

[96] IUCN (2012): IUCN Red List Categories and Criteria: Version 3.1. Second edition. Gland, Switzerland and Cambridge, UK: IUCN. iv + 32pp.

[97] Jepsen, J.U., Hagen, S.B., Ims, R.A., Yoccoz, N.G. (2008): Climate change and outbreaks of the geometrids Operophtera brumata and Epirrita autumnata in subarctic birch forest: evidence of a recent outbreak range expansion. Journal of Animal Ecology, 77: 257-264.

[98] Joint science academies' statement: The science of climate change (ASP). Royal Society, 2001. május 17. (Hozzáférés: 2007. április 1.) „The work of the Intergovernmental Panel on Climate Change (IPCC) represents the consensus of the international scientific community on climate change science".

[99] Jones, J.W., Bowen, H.D., Bradley, J.R., Stinner, R.E., Sowell, R.S. (1975): The boll weevil (Coleoptera: Curculionidae) feeding process: A simulation model. Ecological Modelling, 1(4): 289-302. 
[100] Joos, F., Plattner, G.-K., Stocker, T.F., Marchal, O., Schmittner, A. (1999): Global warming and marine carbon cycle feedbacks on future atmospheric CO2. Science, 284: 464-467.

[101] Kádár F., Szentkirályi F. (1997): Effects of climatic variations on long-term fluctuation patterns of ground beetles (Coleoptera, Carabidae) collected by light trapping in Hungary. Acta Phytopathologica et Entomologica Hungarica, 32: 185-203.

[102] Karafyllidis, I. (1988): A model for the influence of the greenhouse effect on insect and microorganism geographical distribution and population dynamics. Biosystems, 45(1): 1-10.

[103] Kawamoto, H., Sinha, R.N., Muir, W.E. (1992): Cömputer smulation modelling for stored-grain pest management. Journal of Stored Products Research, 28(2): 139-145.

[104] Kearney, M.R., Briscoe, N.J., Karoly, D.J., Porter, W.P., Norgate, M., Sunnucks, P. (2010): Early emergence in a butterfly causally linked to anthropogenic warming. Biology Letters, doi: 10.1098/rsbl.2010.0053

[105] Kenny, G.J., Harrison, P.A., Parry, M.L., Porter, J.R. (1993): The efects of climate change on agriculture and horticulture in Europe. European Journal of Agronomy, 2(4): 243-246.

[106] Kertész Á. (2001): A globális klímaváltozás természetföldrajza. Budapest, Holnap Kiadó Kft. 142. ISBN: 9789633464557

[107] Kindlmann, P., Dixon, A.F.G. (1996): Population dynamics of a tree-dwelling aphid: individuals to populations. Ecological Modelling, 89(1-3): 23-30.

[108] Klok, C.J., Crown, S.L. (2001): Critical thermal limits, temperature tolerance and water balance of a sub-Antarctic kelp fly, Paractora dreuxi (Diptera: Helcomyzidae). Journal of Insect Physiology, 47(1): 95-109.

[109] Koch, M. (1961): Wir Bestimmen Schmetterlinge 4. Band. Neumann Verlag Radebeul. Leipzig. 263.

[110] Kovács L. (1962): A növényvédelmi fénycsapdák 1961. évi eredményeiböl. 12. Növényv. Tud. Ért. 135-137.

[111] Kovács L. (1965): Araszolólepkék I. - Geometridae I. - In: KASZAB (ed.) Fauna Hungariae XVI/8. Budapest, Akadémiai Kiadó, 55.

[112] Kozár F, Szentkirályi F, Kádár F, Bernáth B. (2004): Éghajlatváltozás és a rovarok. “AGRO-21” Füzetek, 33: 49-64.

[113] Krcmar, S., Merdic, E. (1991): The areal enlargement of the species of Colias erate Esp. 1804 (Lepidoptera; Pieridae) in Southeast Europe. Abstract, ECE/SIEEC, Gödöllő, 120. 
[114] Kula, E. (2002): The population and seasonal dynamics of weevils developing in the soil of birch stands. Ecology Survey and Management of Forest Insects, 33.

[115] Ladányi M. (2006): Folyamatszemléleti lehetőségek az agro-szisztémák modellezésében. Doktori $(\mathrm{PhD})$ értekezés, Budapesti Corvinus Egyetem.

[116] Ladányi M., Hufnagel L. (2006): The effect of climate change ont he population of sycamore lace bug (Corythuca ciliata, SAY, Tingidae Heteroptera)based on a simulation model with phenological response. Applied Ecology and Environmental Research 4(2): 85-112.

[117] Lakatos M., Szentimrey T., Bihari Z. (2011): Application of gridded daily data series for calculation of extreme temperature and precipitation indices in Hungary. Időjárás, 115: 99-109.

[118] Láng I., Csete L., Jolánkai M. (2007): A globális klímaváltozás: hazai hatások és válaszok. A VAHAVA jelentés. Budapest, Szaktudás Kiadó Ház, 220. ISBN:9639736177

[119] Leskó K., Szabóky Cs., Tóth J. (1998): Az erdővédelmi figyelö-jelzőszolgálati rendszer története 1961-1998. Erdészeti Tudományos Intézet Kiadványai. 8: 1-64.

[120] Leskó K., Szentkirályi F., Kádár F. (1997): A gyürüszövő (Malocosoma neustria L.) hosszú-távú (1962-1996) populáció-ingadozásai Magyarországon. Erdészeti Kutatások, 86-87: 207-220.

[121] Leskó K., Szentkirályi F., Kádár F. (1998): Araszoló lepkefajok fluktuáció-mintázatának elemzése hosszú távú (1961-1997) magyarországi fényvsapdázási és kártételi idősorokon. Erdészeti Kutatások, 88: 319-334.

[122] Leskó K., Szentkirályi F., Kádár F. (1999): A kis téli araszoló (Operophtera brumata L.) hosszú-távú (1962-1997) populáció-fluktuációinak jellemzése az erdészeti fényvsapda-hálózat mintavételei alapján. Erdészeti Kutatások, 89: 169-182.

[123] Leskó K., Szentkirályi F., Kádár, F. (1994): Gyapjaslepke (Lymantria dispar L.) populációk fluktuációs mintázatai 1963-1993 közötti időszakban Magyarországon. Erdészeti Kutatások, 84: 163-176.

[124] Leskó K., Szentkirályi F., Kádár, F. (1995): Aranyfarkú szövőlepke (Euproctis chrysorrhoea L.) magyarországi populációinak hosszú-távú fluktuációs mintázatai. Erdészeti Kutatások, 85: 169-184.

[125] Letho, T.E. (2003): The number of Lepidoptera species new to Finland is growing. Baptria, 28: 16-22.

[126] Logan, J.A., Regniere, J., Powell, J.A. (2003): Assessing the impacts of global warming on forest pest dynamics. Frontiers in Ecology and the Environment, 1(3): 130-137. 
[127] Marsula, R., Wissel, C. (1994): Insect pest control by a spatial barrier. Ecological Modelling, 75-76: 203-211.

[128] Martinat, P.J. (1987): The role of climatic variation and weather in forest insect outbreaks. In: BARBOSA P. et al. (eds): Insect outbreaks. San Diego. Academic Press, 241-268.

[129] Matter, S.F. (2003): Modeling the density-area relationship in a dynamic landscape: an examination for the beetle Tetraopes tetraophthalmus and a generalized model. Ecological Modelling, 169(1): 103-117.

[130] Mattson, W.J., Haack, R.A. (1987). Role of drought in outbreaks of plant-eating insects. BioScience, 37(2): 110.

[131] Mátyás Cs. (2004): A természetes növénytakaró, az erdő klímaérzékenysége. Természet Világa 135.(II.): 70-73.

[132] Mátyás Cs., Czimber K. (2004): A zonális erdőhatár klímaérzékenysége Magyarországon - előzetes eredmények. In: MÁTYÁS CS., VÍG P. (szerk.): IV. Erdő és Klíma Kötet, NymE, Sopron, 35-44.

[133] McGuffie, K., Henderson-Sellers, A. (2001): Forty Years of Numerical Climate Modelling, In: International Journal of Climatology, 21. (PDF)

[134] McLaughlin, J.F. (2002): Climate change hastens population extinctions. Proceedings of the National Academy of Sciences, 6070-6074. Portable Document Format (2002)04-30

[135] Meehl, G.A., Washington, W.M., Collins, W.D., Arblaster, J.M., Hu, A., Buja, L.E., Strand, W.G. , Teng, H. (2005): „How Much More Global Warming and Sea Level Rise”. Science, 307: 1769-1772. http://www.geo.utexas.edu/courses/387h/PAPERS/ meehl2005. pdf (letöltés: 2007. február 11.)

[136] Mészáros E. (1993): Légkörtan. Veszprém, Veszprémi Egyetemi Kiadó, 120.

[137] Mészáros Z. (1993a): Kis téliaraszoló (Operophthera brumata Linné) 584-589. pp. In: JERMY T., BALÁZS K. (szerk.): A növényvédelmi állattan kézikönyve 4/B. Budapest, Akadémiai Kiadó. 830. ISBN: 9630557401

[138] Mészáros Z. (1993b): Tollacsápú araszoló (Colotois pennaria Linné) 570-572 pp. In: JERMY T., BALÁZS, K. (szerk.): A növényvédelmi állattan kézikönyve 4/B. Budapest, Akadémiai Kiadó. 830. ISBN: 9630557401

[139] Mészáros Z. (2007): Lepkék-Lepidoptera 78. p. In: HALTRICH, A. (szerk.): Növényvédelmi állattan Gyakorlati jegyzet. Budapest, BCE KeTK Rovartani Tanszék. 120. p. 
[140] Mills, N.J., Getz, W.M. (1996): Modelling the biological control of insect pests: a review of host-parasitoid models. Ecological Modelling, 92(2-3): 121-143.

[141] Moon, Y., Kim, J. (2007): Efficient moving average transform-based subsequence matching algorithms in time-series databases. Information Sciences, 177: 5415-5431.

[142] Moss, R.H., Edmonds, J.A., Hibbard, K.A. et al. (2010): The next generation of scenarios for climate change research and assessment. Nature, 463: 747-756.

[143] Mutshinda, C.M., O’Hara, R.B., Woiwod, I.P. (2011): A multispecies perspective on ecological impacts of climatic forcing. Journal of Animal Ecology 80: 101-107.

[144] Münnich Á., Nagy Á., Abari K. (2006): Többváltozós statisztika pszichiológus hallgatók számára. Bölcsész Konzorcium. Debrecen. ISBN: 9639704040 http://psycho. unideb.hu/statisztika

[145] Myers, H.J., Cory, S.J. (2013): Population Cycles in Forest Lepidoptera Revisited. Annual Review Ecology Evolution and Systematics 44: 565-592.

[146] Nakicenovic, N., Swart, R., (szerk.) (2000): Emissions Scenarios. A Special Report of IPCC Working Group III, Cambridge, Cambridge University Press, UK. 570. p.

[147] Naresh, K.M. (2005): Marketingkutatás, Akadémiai Kiadó, 905. p. ISBN: 9630583070

[148] Nelder, J.A. (1961): The fitting of a generalization of the logistic curve. Biometrics, 17: 89-110.

[149] Nowinszky L. (2003): A fénycsapdázás kézikönyve. Szombathely, Savaria University Press. 272. p. ISBN:9639639438146

[150] Paoletti, M.G., Pimentel, D., Stinner, B.R., Stinner, D. (1992): Agroecosystem biodiversity: matching production and conservation biology. Agriculture, Ecosystems and Environment, 40(1-4): 3-21.

[151] Parmesan, C. (1996): Climate and species' range. Nature, 382: 765-766.

[152] Parmesan, C., Ryrholm, N., Stefanescu, C. et al. (1999): Poleward shifts in geographical ranges of butterfly species associated with regional warming. Nature, 399: 579-583.

[153] Parmesan, C., Yohe, G. (2003): A globally coherent fingerprint of climate change impacts across natural systems. Nature, 421: 37-43.

[154] Passioura, J.B. (1973): Sense and nonsense in crop simulation. Journal of the Australian Institute of Agricultural Science, 39: 181-183.

[155] Permesan, C. (1996): Climate and species' range. Nature, 382: 765-766.

[156] Permesan, C. (2006): Ecological and Evolutionary Responses to Recent Climate Change. (PDF). Annual Review of Ecology, Evolution, and Systematics, 37: 637-669. http://www.annualreviews.org/doi/abs/10.1146/annurev.ecolsys.37.091305.110100 Letöltés ideje: 2008. március 30. 
[157] Permesan, C., Ryrholm, N., Stefanescu, C. (1999): Poleward shift sin geographical ranges of butterfly species associated with regional warming. Nature, 399: 579-583.

[158] Peters, R.L. (1990): Effects of global warming on forests. Forest Ecology and Management, 35: 13-33.

[159] Petrányi G., Hufnagel L., Horváth L. (2007): A klímaváltozás és a biodíverzitás kapcsolata - földrajzi analógiai esettanulmány az európai lepkefaunára. „Klíma-21” Füzetek, 50: 62-69.

[160] Phillips, N.A. (1956): The general circulation of the atmosphere: a numerical experiment. Quarterly Journal of the Royal Meteorological Society, 82: 123-164.

[161] Pie, M.R., Rosengaus, R.B., Traniello, J.F.A. (2004): Nest architecture, activity pattern, worker density and the dynamics of disease transmission in social insects. Journal of Theoretical Biology, 226(1): 45-51.

[162] Pieczka I., Bartholy J., Pongrácz R., Hunyady A. (2008): Analysis of expected climate change in the Carpathian Basin using a dynamical climate model. NAA'08: Fourth International Conference on Numerical Analysis and Applications - Abstracts. (eds: Vulkov, L., Angelova, I., Kandilarov, J., Koleva, M.) University of Rousse, Bulgaria. 32.

[163] Pollard, E., Greatorex-Davies, J.N., Thomas, J.A. (1997): Drought reduces breeding success of the butterfly Aglais urticae. Ecological Entomology, 22: 315-318.

[164] Pollard, E., Moss D., Yates, T.J. (1995): Population trends of common British butterflies at monitored sites. Journal of Applied Ecology, 32: 9-16.

[165] Pollard, E., Yates, T.J. (1993): Monitoring Butterflies for Ecology and Conservation. London, Chapman \& Hall. 274. p. ISBN: 0412634600

[166] Pongrácz R., Bartholy J. (2010): A globális felmelegedés. A klímaváltozás tendenciái, területi különbségek, globális felmelegedés. In: TÖRÖ (szerk.): Az éghajlatváltozás hatásai az emberi szervezetre. Budapest, Medicina. 266. p. ISBN: 978-963-226$281-9$

[167] Porter, J.H., Parry, M.L., Carter, T.R. (1991): The potential effects of climatic change on agricultural insect pests. Agricultural and Forest Meteorology, 57: 221-240.

[168] Potting, R.P.J., Perry, J.N., Powell, W. (2005): Insect behavioural ecology and other factors affecting the control efficacy of agro-ecosystem diversification strategies. Ecological Modelling, 182(2): 199-216.

[169] Powell, J.A., Logan , J.A. (2005): Insect seaaonality: circe map analysis of temperaturedriven life cycles. Theoretical Population Biology, 67(3): 161-179. 
[170] Prentice, I.C., Farquhar, G.D., Fasham, M.J.R. et al. (2001): The Carbon Cycle and Atmospheric Carbon Dioxide. 183-237. pp. Chapter 3 in: Houghton, J.T., Ding, Y., Griggs, D.J., Noguer, M., Van der Linden, P.J., Dai, X., Maskell, K., Johnson, C.A. (eds.): Climate Change 2001: The Scientific Basis. Contribution of Working Group I to the Third Assessment Report of the Intergovernmental Panel on Climate Change. Cambridge University Press.

[171] Radchuk, V., Turlure, C., Schtickzelle, N. (2013): Each life stage matters: the importance of assessing the response to climate change over the complete life cycle in butterflies. Journal of Animal Ecology, 82: 275-285.

[172] Raffy, M., Tran, A. (2005): On the dynamics of flying insects population controlled by large scale information. Theoretical Population Biology, 68(2): 91-104.

[173] Rasgon, J.L., Scott, T.W. (2004): Impact of population age structure on Wolbachia transgene driver efficacy: Ecological complex factors and release of geneticallymodified mosquitoes. Insect Biochemistry and Molecular Biology, 34(7): 707-713.

[174] Rausher, M.D. (1985): Variability for host preference in insect populations: Mechanistic and evolutionary models. Journal of Insect Physiology, 31(11): 873-889.

[175] Reichart G. (1950): Újszerű védekezés az araszolóhernyók ellen. Kert és Szőlő, 2(16): 1415.

[176] Reichart G. (1955): Téli nagy araszolópille élete és kártétele (Erannis defoliaria). Kert és Szölö, 4(11): 26.

[177] Reichart G. (1993a): Nagy téliaraszoló (Erannis defoliaria Clerck). 558-566. p. In: JERMY T., BALÁZS K. (szerk.): A növényvédelmi állattan kézikönyve 4/B. Budapest, Akadémiai Kiadó. 830. p. ISBN: 9630557401

[178] Reichart G. (1993b): Aranysárga téliaraszoló (Erannis aurantiaria Hübner). 566-568 p. In: JERMY T., BALÁZS K. (szerk.): A növényvédelmi állattan kézikönyve 4/B. Budapest, Akadémiai Kiadó. 830. p. ISBN: 9630557401

[179] Reichholf-Riehm, H. (1996): Lepkék. Budapest, Magyar Könyvklub. 287. p. ISBN: 9635482930

[180] Richards, F.J. (1959): A flexible growth function for empirical use. Journal of Experimental Botany, 10: 290-300.

[181] Ricker, W.E., (1954): Stock and recruitment. Journal of the Fisheries Research Board of Canada, 115: 559-623.

[182] Roberts, E.A., Ravlin, F.W., Fleischer, S.J. (1993): Spatial data representation for integrated pest management programs. American Entomologist, 39(17): 92-108. 
[183] Roeckner, E., Arpe, K. (1995): AMIP-Experiments with the new Max Planck Institute model ECHAM4. Proceedings of the First International AMIP Scientific Conference, Monterey, California, USA, 15-19 May 1995, WCRP-92, WMP/TD-No. 732, 307-312.

[184] Roeckner, E., Bauml, G., Bonaventura, L. et al. (2003): The atmospheric general circulation model ECHAM-5: Part 1. Hamburg, Max-Planck-Insitut für Meteorologie. Technical Report, 349.

[185] Roy, D.B., Rothery, P., Moss, D., Pollard, E., Thomas, J.A. (2001): Butterfly numbers and waether: predicting historical trends in abundance and the future effects of climate change. Journal of Animal Ecology, 70: 201-217.

[186] Roy, D.B., Sparks, T.H. (2000): Phenology of British butterflies and climate change. Global Change Biology, 6(4): 407-416.

[187] Rubtsov, V.V. (1983): Mathematical model for development of leaf-eating insects (oak leaf roller taken as an example). Ecological Modelling, 18(3-4): 269-289.

[188] Salama, N.K.G., Knowler, J.T., Adams C.E. (2007): Increasing abundance and diversity int he month assemblage of east Loch Lomondside, Scotland over a 35 year period. Journal of Insect Conservation, 11: 151-156.

[189] Salvadori, C., Maresi, G. (2008): Forest health situation in Trentino, Italy. Forstschutz Aktuell, 44: 21-22.

[190] Sarmiento, J.L., Hughes, T.M.C., Stouffer, R.J., Manabe, S. (1998): Simulated response of the ocean carbon cycle to antropogenic climate warming. Nature, 393: 245-249.

[191] Sawyer, A.J., Haynes, D.L. (1985): Simulating the spatiotemporal dynamics of the cereal leaf beetle in a regional crop system. Ecological Modelling, 30(1-2): 83-104.

[192] Schwarz, G. (1978): Estimating the dimension of a model. Annals of Statistics, 6: 461464.

[193] Schwerdtfeger, F. (1979): Ökologie der Tiere, Bd. II: Demökologie. 2. Aufl. Verlag Paul Parey. Hamburg und Berlin.

[194] Semenov, M.A., Porter, J.R. (1995): Non-linearities in climate change impact assessments. Journal of Biogeography, 22: 597-600.

[195] Semenov, M.A., Porter, J.R., Delecolle, R. (1993): Simulation of the effects of climatic change on the growth and development of wheat in the UK and France. European Journal of Agronomy, 2(4): 293-304.

[196] Settele, J., Kudrna, O., Harpke, A. et al. (2008): Climatic Risk Atlas of European Butterflies, Biorisk 1. Sofia, Pensoft Publishers, 710 pp. ISBN 978-954-642-454-9 
[197] Shaffer, P.L., Gold, H.J. (1985): A simulation model of population dynamics of the codling moth, Cydia pomonella. Ecological Modelling, 30(3-4): 247-274.

[198] Shelford, R. (1913): Orthoptères. Blattides, Mantides et Phasmides. Mission du Service Géographique de L'Armée pour la Mesure d'un Arc de Méridien Equatorial en Amérique du Sud sous le contrôle scientifique de L'Académie des Sciences 18991906. 10(1): 57-62.

[199] Siegenthaler, U., Stocker, T.F., Monnin, E., Lüthi, D., Schwander, J., Stauffer, B., JeanMarc T.F., Fischer, H., Masson-Delmotte, V., Jouzel, J. (2005): Stable Carbon Cycle-Climate Relationship During the Late Pleistocene. Science, 310: 1313-1317.

[200] Sipkay Cs., Drégelyi-Kiss Á., Horváth L., Garmvölgyi Á., Tihamér Keve K., Hufnagel L. (2010): Community ecological effects of climate change. In: SIMARD, S.W., AUSTIN, M.E. (Ed.) Climate Change and Variability Sciyo. 139-162. p. ISBN: 978-953-307-144-2

[201] Sparks, T.H. (1999): Phenology and the changing pattern of bird migration in Britain. International Journal of Biometeorology, 42: 134-138.

[202] Sparks, T.H., Carey, P.D. (1995): The response of species to climate over two centuries: an analysis of the Marsham phenological record 1736-1947. Journal of Ecology, 83: 321-329.

[203] Sparks, T.H., Yates, T.J. (1997): The effect of spring temperature on the appearance dates of British butterflies 1883-1993. Ecography, 20: 368-374.

[204] Stefanescu, C., Penuelas, J., Filella, I. (2003): Effects of climatic change on the phenology of butterfl ies in the Northwest Mediterranean Basin. Global Change Biology, 9 (10): 1494-1506.

[205] Szabóky Cs., Csóka Gy. (2008): A püpökladányi Farkassziget lepkéi. Budapest, Erdészeti Tudományos Intézet. 136 p. ISBN 978-963-7349-34-8

[206] Szalai S., Bihari Z., Lakatos M., Szentimrey T. (2005): Magyarország éghajlatának néhány jellemzője 1901-től napjainkig. OMSZ.

[207] Szanyi Sz. (2011): Vándorló és terjedő nagylepkefajok (Lepidoptera, Macroheterocera) Kárpátalján. Acta Beregsasiensis, X.(1): 179-183.

[208] Szentkirályi F., Leskó K. (2007): Lepkék. 65-88. pp. In: CZÚCZ B, KRÖEL-DULAY GY., RÉDEI T., BOTTA-DUKÁT Z., MOLNÁR ZS. (szerk.): Éghajlatváltozás és biológiai sokféleség - elemzések az adaptációs stratégia tudományos megalapozásához. Kutatási jelentés. MTA ÖBKI. 278. p. 
[209] Szentkirályi F., Leskó K., Kádár F. (1995): Jeleznek-e klímaváltozást a fénycsapdás rovargyüjtések? 171-177. p. In: TAR K. és mtsi (szerk.): I. Erdö és klíma Konferencia Kötet. Debrecen

[210] Szentkirályi F., Leskó K., Kádár F. (1998): Aszályos évek hatása a rovarpopulációk hosszútávú fluktuációs mintázatára. 94-98. pp. In: TAR K. és mtsi (szerk.): II. Erdö és klíma Konferencia Kötet. Debrecen

[211] Szépszó G., Bartholy J., Csima G., Horányi A., Hunyady A., Pieczka I., Pongrácz R., Torma CS. (2008): Validation of different regional climate models over the Carpathian Basin. EMS8/ECAC7 Abstracts, 5, EMS2008-A-00645.

[212] Szépszó G., Bölöni G., Horányi A., Szűcs M., (2013): A numerikus időjárási modellek felépítése: tér- és időskála, adatasszimiláció, diszkretizáció, parametrizációk, valószínűségi előrejelzések, éghajlati modellezés. In: WEIDINGER T., GYÖNGYÖSI A. Z (szerk.): Alkalmazott számszerü elörejelzés. elektronikus egyetemi jegyzet. (PDF)

[213] Szépszó G., Horányi, A. (2008): Transient simulation of the REMO regional climate model and its evaluation over Hungary. Időjárás, 112: 213-232.

[214] Szontagh P. (1977): Tölgykárosító araszoló fajok (Geometridae) gradációs viszonyai Magyarországon. Folia Entomologica Hungarica, 30(1): 173-192.

[215] Szontagh P. (1980): Gradationverhältnisse der eichenschädlicher Geometriden Arten in Ungarn. Prace Muzea V, Hradcy Kralove. 257-259.

[216] Szőcs G. (1976): A kis téliaraszoló (Operophtera brumata L.) életmódja. Állattani Közlemények, 83: 237-238.

[217] Szücs E. (1972): Hasonlóság és modell, Müszaki Kiadó, Budapest 299. p.

[218] Szücs E. (1990): Rendszer és modell I-II. Tankönyvkiadó, Budapest 290. p.

[219] Tchuenche, J.M. (2005): An Age-Structured Model with Delay Mortality. BioSystems, 81(3): 255-260.

[220] Thorpe, G.R. (1997): Modelling ecosystems in ventilated conical bottomed farm grain silos. Ecological Modelling, 94(2-3): 255-286.

[221] Thorpe, G.R., Cuff, W.R., Longstaff, B.C. (1982): Control of Sitophilus oryzae (L.) infestations of stored wheat: An ecosyste model of the use of aeration. Ecological Modelling, 15(4): 331-351.

[222] Tomescu, R., Netoiu, C. (2006): Control of the Broad Leave's Mains Defoliators in Romania in 2005. Proceedings of IUFRO Working Party 7.03.10 Workshop on „Metodology of Forest Insect and Disease Survey in Central Europe”, (CD), Federal 
Research \& Training Centre for Forests, Natural Hayards \& Landscape, Gmunden Austria, $263-270$.

[223] Torma Cs. (2011): Átlagos és szélsőséges hőmérsékleti és csapadék viszonyok modellezése a Kárpát-medencére a XXI. századra a RegCM regionális klímamodell alkalmazásával. Doktori Értekezés (PhD) http://teo.elte.hu/minosites/ertekezes2011/ torma_cs_zs.pdf letöltve: 2012. szeptember 30 .

[224] Torma Cs., Bartholy J., Pongracz R., Barcza Z., Coppola, E., Giorgi, F. (2008): Adaptation and validation of the RegCM3 climate model for the Carpathian Basin. Időjárás, 112(3-4): 233-247.

[225] Torma Cs., Coppola, E., Giorgi, F., Bartholy J., Pongrácz R. (2011): Validation of a high resolution version of the regional climate model RegCM3 over the Carpathian Basin. Journal of Hydrometeorology, 12(1): 84-100.

[226] Tóth J. (1999): Erdészeti rovartan. Budapest, Agroinform Kiadó. 480. p. ISBN: 963502696 X

[227] Törő K. (szerk.) (2010): Az éghajlatváltozás hatásai az emberi szervezetre. Budapest, Medicina Könyvkiadó Rt., 266. p. ISBN: 978-963-226-281-9

[228] Trenberth, K.E., (1992): Coupled Climate System Modelling. Cambridge. Cambridge University Press. 788. p. ISBN: 0521432316

[229] Turkheimer, F.E., Hinz, R., Cunningham, V.J. (2003): On the undecidability among kinetic models: from model selection to model averaging. Journal of Cerebral Blood Flow \& Metabolism, 23: 490-498.

[230] Tyndall, J. (1862): On Radiation through the Earth's Atmosphere. Philosophical Magazine, 4(25): 200-206.

[231] Ulanowicz, R.E. (1983): Identifying the structure of cycling in ecosystems. Mathematical Biosciences, 65: 219-237.

[232] Ulanowicz, R.E., Wolff, W.F. (1991): Ecosystem flow networks: Loaded dice? Mathematical Biosciences, 103: 45-68.

[233] Varga Z., Ronkay L., Bálint Zs., László M., Peregovits, L. (2004): A magyar állatvilág fajjegyzéke. 3. kötet. Nagylepkék. [Checklist of the fauna of Hungary. 3. Macrolepidoptera.] - Magyar Természettudományi Múzeum, Budapest, 111.

[234] Velichko, A.A., Borisova, O.K., Zelikson, E.M., Faure, H., Adams, J.M., Branchu, P., Fauredenard, L. (1993): Greenhouse Warming and the Eurasian Biota - Are There Any Lessons From the Past. Global and Planetary Change, 7(1-3): 51-67.

[235] Verhulst, P.F. (1838): Notice sur la loi logistique de la population suit dans son accrossement. Correspondence Mathématique et Physique, 10: 113-121. 
[236] Visser, M.E., Holleman, L.J.M. (2001): Warmer springs disrupt the synchrony of oak and wintermoth phenology. Proceedings of the Royal Society of London Series B, 268: 289-294.

[237] Visser, M.E., Holleman, L.J.M., Gienapp, P. (2006): Shifts in caterpillar biomass phenology due to climate change and its impact on the breeding biology of an insectivorous bird. Oecologia, 147: 164-172.

[238] Volney, W.J.A., Fleming, R.A. (2000): Climate change and impacts of boreal forest insects. Agriculture Ecosystems and Environment, 82: 283-294.

[239] Vörös G. (2002): A globális felmelegedés és a klímaingadozás hatása néhány rovarkártevőre, valamint leküzdésük lehetőségei. PhD értekezés. Keszthely, 196.p.

[240] Wagner, T.L., Gagne, J.A., Sharpe, P.J.H., Coulson, R.N. (1984): A biophysical model of southern pine beetle, Dendroctonus frontalis Zimmermann (Coleoptera: Scolytidae), development. Ecological Modelling, 21(1-2): 125-147.

[241] Walther, G.R., Post, E., Convey, P., Menzel, A., Parmesan, C., Beebee, T.J.C., Fromentin, J.M., Hoegh-Guldberg, O.H., Bairlein, F. (2002): Ecological responses to recent climate change. Nature, 416: 389-395.

[242] Walther, G-R., Post, E., Convey, P., Menzel, A., Parmesan, C., Beebee, T.J.C., Fromentin, J-M., Hoegh-Guldberg, O., Bairlein, F. (2002): Ecological response to recent climate change. Nature, 416: 389-395.

[243] Waring, G.L., Price, P.W. (1990): Plant water stress and gall formation (Cecidomyiidae: Asphondylia spp.) on creosote bush. Ecological Entomology, 15: 87-95.

[244] Warrick, R.A., Gifford, R., Parry, M.L. (1986): "CO2, climate change and agriculture", In: BOLIN, B., DOOS, B.R., JAGER, J., WARRICK, R.A. (eds): John Wiley and Sons, (SCOPE 29), The Creenhouse Effect, Climatic Change and Ecosystems, Chichester, UK 393-473.

[245] Webb, T., Wigley, T.M.L. (1985): "What past climates can tell us about a warmer world.” In: MacCRACKEN, M.C., LUTHER, F.M. (Eds.): Projecting the Climatic Effects of Increasing Carbon Dioxide, Washington, D.C., United States Department of Energy, 237-257.

[246] Weise, T. (2009): Global Optimization Algorithms: Theory and Application. E-book. http://www.it-weise.de/projects/book.pdf

[247] White, K.A.J., Wilson, K. (1999): Modelling density-dependent resistance in insectpathogen interactions. Theoretical Population Biology, 56 (2): 163-181.

[248] Williams, D.W, Liebhold, A.M. (1995): Forest defoliators and climatic change: Potential changes in spatial distribution of outbreaks of western spruce budworm 
(Lepidoptera: Tortricidae) and gypsy moth (Lepidoptera: Lymantriidae). Environmental Entomology, 24: 2-9.

[249] Woiwod, I.P. (1997): Detecting the effects of climate change on Lepidoptera. Journal of Insect Conservation, 1: 149-158.

[250] Zeng, N., Qian, H., Munoz, E., Iacono, R. (2004): How strong is carbon cycle-climate feedback under global warming? Geophysical Research Letters, 31: 201-203.

\section{Elektronikus forrásmegjelölések:}

[251] http://www.iucn.org/about/work/programmes/species/our_work/the_iucn_red_list/

[252] http://www.met.hu/eghajlat/eghajlatvaltozas/eghajlatvaltozas_okai/ letöltve: 2012. szeptember 21.

[253] http://www.pik-potsdam.de/ 
RÖVIDÍTÉSEK JEGYZÉKE

AOGCM - Atmosphere-Ocean General Circulation Model

FAO - Az Egyesült Nemzetek Élelmezésügyi és Mezőgazdasági Szervezete, angolul Food and Agriculture Organization of the United Nations

IPCC - Éghajlat-változási Kormányközi Testület, angolul International Panel of Climate Change

IUCN - A Természetvédelmi Világszövetség (angolul World Conservation Union vagy International Union for Conservation of Nature and Natural Resources

NCAR - National Center for Atmospheric Research

PIK - A PIK Intézet Potsdam Institut für Klimatfolgen-Forschung = az Éghajlati Hatások Potsdami Intézete

ppm - A szén-dioxid-koncentráció mérésére nemzetközileg egységesen használt mértékegység. A ppm jelentése parts per million, magyarul rész a millióban. 1 ppm $=10$ - 6 


\section{MELLÉKLETEK JEGYZÉKE}

M1. Az j-edik hónap napi középhőmérsékleteinek átlaga (MTATLt_j)

M2. A j-edik hónap napi minimumhőmérsékleteinek átlaga (MTMIN $t \_j$ )

M3. A j-edik hónap napi maximumhömérsékleteinek átlaga (MTMAXt_j)

M4. A j-edik hónap napi csapadékmennyiségének átlaga (MRAIN $t_{-} j$ )

M5. A j-edik hónap napi minimumhőmérsékleteinek minimuma (MTMINNt_j)

M6. A j-edik hónap napi maximumhőmérsékleteinek maximuma (MTMAXX $t_{-} j$ )

M7. Az i-edik dekád napi középhőmérsékleteinek átlaga (TATLt_i)

M8. Az $i$-edik dekád napi minimumhőmérsékleteinek átlaga (TMIN $t \_i$ )

M9. Az i-edik dekád napi maximumhőmérsékleteinek átlaga (TMAXt_i)

M10. Az i-edik dekád napi csapadékmennyiségének átlaga (RAINt_i)

M11. Az $i$-edik dekád napi minimumhőmérsékleteinek minimuma (TMINN $t$ _ $i$ )

M12. Az i-edik dekád napi maximumhömérsékleteinek maximuma (TMAXXt_i).

M13. A klimatikus indikátorok fajonkénti értékelése 


\section{MELLÉKLETEK}

M1. Az j-edik hónap napi középhőmérsékleteinek átlaga (MTATLt_j)

\begin{tabular}{|c|l|c|}
\hline KÓD & \multicolumn{1}{|c|}{ Indikátor } & Intervallum \\
\hline MTATL1 & vizsgált év 1. hónapjának napi középhőmérsékleteinek átlaga & január \\
\hline MTATL2 & vizsgált év 2. hónapjának napi középhőmérsékleteinek átlaga & február \\
\hline MTATL3 & vizsgált év 3. hónapjának napi középhőmérsékleteinek átlaga & március \\
\hline MTATL4 & vizsgált év 4. hónapjának napi középhőmérsékleteinek átlaga & április \\
\hline MTATL5 & vizsgált év 5. hónapjának napi középhőmérsékleteinek átlaga & május \\
\hline MTATL6 & vizsgált év 6. hónapjának napi középhőmérsékleteinek átlaga & június \\
\hline MTATL7 & vizsgált év 7. hónapjának napi középhőmérsékleteinek átlaga & július \\
\hline MTATL8 & vizsgált év 8. hónapjának napi középhőmérsékleteinek átlaga & augusztus \\
\hline MTATL9 & vizsgált év 9. hónapjának napi középhőmérsékleteinek átlaga & szeptember \\
\hline MTATL10 & vizsgált év 10. hónapjának napi középhőmérsékleteinek átlaga & október \\
\hline MTATL11 & vizsgált év 11. hónapjának napi középhőmérsékleteinek átlaga & november \\
\hline MTATL12 & vizsgált év 12. hónapjának napi középhőmérsékleteinek átlaga & december \\
\hline EMTATLj & előző év $j$. hónapjának napi középhőmérsékleteinek átlaga & \\
\hline
\end{tabular}

M2. A j-edik hónap napi minimumhőmérsékleteinek átlaga (MTMINt_j)

\begin{tabular}{|c|l|c|}
\hline KÓD & \multicolumn{1}{|c|}{ Indikátor } & intervallum \\
\hline MTMIN1 & vizsgált év 1. hónapjának napi minimumhőmérsékleteinek átlaga & január \\
\hline MTMIN2 & vizsgált év 2. hónapjának napi minimumhőmérsékleteinek átlaga & február \\
\hline MTMIN3 & vizsgált év 3. hónapjának napi minimumhőmérsékleteinek átlaga & március \\
\hline MTMIN4 & vizsgált év 4. hónapjának napi minimumhőmérsékleteinek átlaga & április \\
\hline MTMIN5 & vizsgált év 5. hónapjának napi minimumhőmérsékleteinek átlaga & május \\
\hline MTMIN6 & vizsgált év 6. hónapjának napi minimumhőmérsékleteinek átlaga & június \\
\hline MTMIN7 & vizsgált év 7. hónapjának napi minimumhőmérsékleteinek átlaga & július \\
\hline MTMIN8 & vizsgált év 8. hónapjának napi minimumhőmérsékleteinek átlaga & augusztus \\
\hline MTMIN9 & vizsgált év 9. hónapjának napi minimumhőmérsékleteinek átlaga & szeptember \\
\hline MTMIN10 & vizsgált év 10. hónapjának napi minimumhőmérsékleteinek átlaga & október \\
\hline MTMIN11 & vizsgált év 11. hónapjának napi minimumhőmérsékleteinek átlaga & november \\
\hline MTMIN12 & vizsgált év 12. hónapjának napi minimumhőmérsékleteinek átlaga & december \\
\hline EMTMINj & előző év $j$. hónapjának napi minimumhőmérsékleteinek átlaga & \\
\hline
\end{tabular}


M3. A j-edik hónap napi maximumhőmérsékleteinek átlaga (MTMAXt_j)

\begin{tabular}{|c|l|c|}
\hline KÓD & \multicolumn{1}{|c|}{ Indikátor } & Intervallum \\
\hline MTMAX1 & vizsgált év 1. hónapjának napi maximumhőmérsékleteinek átlaga & január \\
\hline MTMAX2 & vizsgált év 2. hónapjának napi maximumhőmérsékleteinek átlaga & február \\
\hline MTMAX3 & vizsgált év 3. hónapjának napi maximumhőmérsékleteinek átlaga & március \\
\hline MTMAX4 & vizsgált év 4. hónapjának napi maximumhőmérsékleteinek átlaga & április \\
\hline MTMAX5 & vizsgált év 5. hónapjának napi maximumhőmérsékleteinek átlaga & május \\
\hline MTMAX6 & vizsgált év 6. hónapjának napi maximumhőmérsékleteinek átlaga & június \\
\hline MTMAX7 & vizsgált év 7. hónapjának napi maximumhőmérsékleteinek átlaga & július \\
\hline MTMAX8 & vizsgált év 8. hónapjának napi maximumhőmérsékleteinek átlaga & augusztus \\
\hline MTMAX9 & vizsgált év 9. hónapjának napi maximumhőmérsékleteinek átlaga & szeptember \\
\hline MTMAX10 & vizsgált év 10. hónapjának napi maximumhőmérsékleteinek átlaga & október \\
\hline MTMAX11 & vizsgált év 11. hónapjának napi maximumhőmérsékleteinek átlaga & november \\
\hline MTMAX12 & vizsgált év 12. hónapjának napi maximumhőmérsékleteinek átlaga & december \\
\hline EMTMAXj & előző év $j$. hónapjának napi maximumhőmérsékleteinek átlaga & \\
\hline
\end{tabular}

M4. A j-edik hónap napi csapadékmennyiségének átlaga (MRAINt_j)

\begin{tabular}{|c|l|c|}
\hline KÓD & \multicolumn{1}{|c|}{ Indikátor } & Intervallum \\
\hline MRAIN1 & vizsgált év 1. hónapjának napi csapadékmennyiségének átlaga & január \\
\hline MRAIN2 & vizsgált év 2. hónapjának napi csapadékmennyiségének átlaga & február \\
\hline MRAIN3 & vizsgált év 3. hónapjának napi csapadékmennyiségének átlaga & március \\
\hline MRAIN4 & vizsgált év 4. hónapjának napi csapadékmennyiségének átlaga & április \\
\hline MRAIN5 & vizsgált év 5. hónapjának napi csapadékmennyiségének átlaga & május \\
\hline MRAIN6 & vizsgált év 6. hónapjának napi csapadékmennyiségének átlaga & június \\
\hline MRAIN7 & vizsgált év 7. hónapjának napi csapadékmennyiségének átlaga & július \\
\hline MRAIN8 & vizsgált év 8. hónapjának napi csapadékmennyiségének átlaga & augusztus \\
\hline MRAIN9 & vizsgált év 9. hónapjának napi csapadékmennyiségének átlaga & szeptember \\
\hline MRAIN10 & vizsgált év 10. hónapjának napi csapadékmennyiségének átlaga & október \\
\hline MRAIN11 & vizsgált év 11. hónapjának napi csapadékmennyiségének átlaga & november \\
\hline MRAIN12 & vizsgált év 12. hónapjának napi csapadékmennyiségének átlaga & december \\
\hline EMRAIN $j$ & előző év $j$. hónapjának napi csapadékmennyiségének átlaga & \\
\hline
\end{tabular}


M5. A j-edik hónap napi minimumhőmérsékleteinek minimuma (MTMINN $t \_j$ )

\begin{tabular}{|c|l|c|}
\hline \multicolumn{1}{|c|}{ KÓD } & \multicolumn{1}{|c|}{ Indikátor } & Intervallum \\
\hline MTMINN1 & vizsgált év 1. hónapjának napi minimumhőmérsékletének minimuma & Január \\
\hline MTMINN2 & vizsgált év 2. hónapjának napi minimumhőmérsékletének minimuma & Február \\
\hline MTMINN3 & vizsgált év 3. hónapjának napi minimumhőmérsékletének minimuma & Március \\
\hline MTMINN4 & vizsgált év 4. hónapjának napi minimumhőmérsékletének minimuma & Április \\
\hline MTMINN5 & vizsgált év 5. hónapjának napi minimumhőmérsékletének minimuma & Május \\
\hline MTMINN6 & vizsgált év 6. hónapjának napi minimumhőmérsékletének minimuma & Június \\
\hline MTMINN7 & vizsgált év 7. hónapjának napi minimumhőmérsékletének minimuma & Július \\
\hline MTMINN8 & vizsgált év 8. hónapjának napi minimumhőmérsékletének minimuma & Augusztus \\
\hline MTMINN9 & vizsgált év 9. hónapjának napi minimumhőmérsékletének minimuma & Szeptember \\
\hline MTMINN10 & vizsgált év 10. hónapjának napi minimumhőmérsékletének minimuma & Október \\
\hline MTMINN11 & vizsgált év 11. hónapjának napi minimumhőmérsékletének minimuma & November \\
\hline MTMINN12 & vizsgált év 12. hónapjának napi minimumhőmérsékletének minimuma & December \\
\hline EMTMINNj & előző év $j$. hónapjának napi minimumhőmérsékletének minimuma & \\
\hline
\end{tabular}

M6. A j-edik hónap napi maximumhőmérsékleteinek maximuma (MTMAXXt_j)

\begin{tabular}{|c|l|c|}
\hline KÓD & \multicolumn{1}{|c|}{ Indikátor } & Intervallum \\
\hline MTMAXX1 & vizsgált év 1. hónapjának napi maximumhőmérsékletének maximuma & január \\
\hline MTMAXX2 & vizsgált év 2. hónapjának napi maximumhőmérsékletének maximuma & február \\
\hline MTMAXX3 & vizsgált év 3. hónapjának napi maximumhőmérsékletének maximuma & március \\
\hline MTMAXX4 & vizsgált év 4. hónapjának napi maximumhőmérsékletének maximuma & április \\
\hline MTMAXX5 & vizsgált év 5. hónapjának napi maximumhőmérsékletének maximuma & május \\
\hline MTMAXX6 & vizsgált év 6. hónapjának napi maximumhőmérsékletének maximuma & június \\
\hline MTMAXX7 & vizsgált év 7. hónapjának napi maximumhőmérsékletének maximuma & július \\
\hline MTMAXX8 & vizsgált év 8. hónapjának napi maximumhőmérsékletének maximuma & augusztus \\
\hline MTMAXX9 & vizsgált év 9. hónapjának napi maximumhőmérsékletének maximuma & szeptember \\
\hline MTMAXX10 & vizsgáltt év 10. hónapjának napi maximumhőmérsékletének maximuma & október \\
\hline MTMAXX11 & vizsgált év 11. hónapjának napi maximumhőmérsékletének maximuma & november \\
\hline MTMAXX12 & vizsgált év 12. hónapjának napi maximumhőmérsékletének maximuma & december \\
\hline EMTMAXXj & előző év j. hónapjának napi maximumhőmérsékletének maximuma & \\
\hline
\end{tabular}


M7. Az i-edik dekád napi középhőmérsékleteinek átlaga (TATLt_i)

\begin{tabular}{|c|c|c|c|}
\hline KÓD & Indikátor & Intervallum & $\begin{array}{c}\text { intervalluma } \\
\text { (szőkóév) }\end{array}$ \\
\hline TATL1 & vizsgált év 1. dekádjának napi középhőmérsékleteinek átlaga & jan. 1.- jan. 10. & jan. 1.- jan. 10 . \\
\hline TATL2 & vizsgált év 2. dekádjának napi középhőmérsékleteinek átlaga & jan. 11.- jan. 20. & jan. 11.- jan. 20. \\
\hline TATL3 & vizsgált év 3. dekádjának napi középhőmérsékleteinek átlaga & jan. 21.- jan. 30. & jan. 21.- jan. 30. \\
\hline TATL4 & vizsgált év 4. dekádjának napi középhőmérsékleteinek átlaga & jan.31.- febr. 9. & jan.31.- febr. 9. \\
\hline TATL5 & vizsgált év 5. dekádjának napi középhőmérsékleteinek átlaga & febr.10.- febr.19. & febr.10.- febr.19. \\
\hline TATL6 & vizsgált év 6. dekádjának napi középhőmérsékleteinek átlaga & febr.20.- márc. 1. & febr.20.- febr.29. \\
\hline TATL7 & vizsgált év 7. dekádjának napi középhőmérsékleteinek átlaga & márc. 2.- márc. 11. & márc. 1.- márc. 10. \\
\hline TATL8 & vizsgált év 8. dekádjának napi középhőmérsékleteinek átlaga & márc. 12.- márc. 21. & márc. 11.- márc. 20. \\
\hline TATL9 & vizsgált év 9. dekádjának napi középhőmérsékleteinek átlaga & márc. 22.- márc. 31. & márc. 21.- márc. 30. \\
\hline TATL10 & vizsgált év 10. dekádjának napi középhőmérsékleteinek átlaga & ápr. 1. - ápr. 10. & márc. 31. - ápr. 9. \\
\hline TATL11 & vizsgált év 11. dekádjának napi középhőmérsékleteinek átlaga & ápr. 11. - ápr. 20. & ápr. 10. - ápr. 19. \\
\hline TATL12 & vizsgált év 12. dekádjának napi középhőmérsékleteinek átlaga & ápr. 21. - ápr. 30. & ápr. 20. - ápr. 29. \\
\hline TATL13 & vizsgált év 13. dekádjának napi középhőmérsékleteinek átlaga & máj. 1. - máj. 10. & ápr. 30. - máj. 9. \\
\hline TATL14 & vizsgált év 14. dekádjának napi középhőmérsékleteinek átlaga & máj. 11. - máj. 20. & máj. 10. - máj. 19. \\
\hline TATL15 & vizsgált év 15. dekádjának napi középhőmérsékleteinek átlaga & máj. 21. - máj. 30. & máj. 20. - máj. 29. \\
\hline TATL16 & vizsgált év 16. dekádjának napi középhőmérsékleteinek átlaga & máj. 31. - jún. 9. & máj. 30. - jún. 8. \\
\hline TATL17 & vizsgált év 17. dekádjának napi középhőmérsékleteinek átlaga & jún. 10. - jún. 19. & jún. 9. - jún. 18. \\
\hline TATL18 & vizsgált év 18. dekádjának napi középhőmérsékleteinek átlaga & jún. 20. - jún. 29. & jún. 19. - jún. 28. \\
\hline TATL19 & vizsgált év 19. dekádjának napi középhőmérsékleteinek átlaga & jún. 30. - júl. 9. & jún. 29. - júl. 8. \\
\hline TATL20 & vizsgált év 20. dekádjának napi középhőmérsékleteinek átlaga & júl. 10. - júl. 19. & júl. 9. - júl. 18. \\
\hline TATL21 & vizsgált év 21. dekádjának napi középhőmérsékleteinek átlaga & júl. 20. - júl. 29. & júl. 19. - júl. 28. \\
\hline TATL22 & vizsgált év 22. dekádjának napi középhőmérsékleteinek átlaga & júl. 30. -aug. 8 . & júl. 29. -aug. 7. \\
\hline TATL23 & vizsgált év 23. dekádjának napi középhőmérsékleteinek átlaga & aug. 9. - aug. 18. & aug. 8. - aug. 17. \\
\hline TATL24 & vizsgált év 24. dekádjának napi középhőmérsékleteinek átlaga & aug. 19. - aug. 28. & aug. 18. - aug. 27. \\
\hline TATL25 & vizsgált év 25. dekádjának napi középhőmérsékleteinek átlaga & aug. 29. - szept. 7. & aug. 28. - szept. 6. \\
\hline TATL26 & vizsgált év 26. dekádjának napi középhőmérsékleteinek átlaga & szept. 8. - szept. 17. & szept. 7. - szept. 16. \\
\hline TATL27 & vizsgált év 27. dekádjának napi középhőmérsékleteinek átlaga & szept. 18. - szept. 27. & szept. 17. - szept. 26. \\
\hline TATL28 & vizsgált év 28. dekádjának napi középhőmérsékleteinek átlaga & szept. 28. - okt. 7. & szept. 27. - okt. 6. \\
\hline TATL29 & vizsgált év 29. dekádjának napi középhőmérsékleteinek átlaga & okt. 8. - okt. 17. & okt. 7. - okt. 16. \\
\hline TATL30 & vizsgált év 30. dekádjának napi középhőmérsékleteinek átlaga & okt. 18. - okt. 27. & okt. 17. - okt. 26. \\
\hline TATL31 & vizsgált év 31. dekádjának napi középhőmérsékleteinek átlaga & okt. $28 .-$ nov. 6. & okt. 27. - nov. 5. \\
\hline TATL32 & vizsgált év 32. dekádjának napi középhőmérsékleteinek átlaga & nov. 7. - nov. 16. & nov. 6. - nov. 15. \\
\hline TATL33 & vizsgált év 33. dekádjának napi középhőmérsékleteinek átlaga & nov. 17. - nov. 26. & nov. 16. - nov. 25. \\
\hline TATL34 & vizsgált év 34. dekádjának napi középhőmérsékleteinek átlaga & nov. 27. - dec. 6. & nov. 26. - dec. 5. \\
\hline TATL35 & vizsgált év 35. dekádjának napi középhőmérsékleteinek átlaga & dec. 7. - dec. 16. & dec. 6. - dec. 15. \\
\hline TATL36 & vizsgált év 36. dekádjának napi középhőmérsékleteinek átlaga & dec. $17 .-$ dec. 26. & dec. $16 .-$ dec. 25. \\
\hline TATL37 & vizsgált év 37. dekádjának napi középhőmérsékleteinek átlaga & dec. 27. - dec. 31 . & dec. 26. - dec. 31 . \\
\hline ETATLi & előző év $i$. dekádjának napi középhőmérsékleteinek átlaga & & \\
\hline
\end{tabular}


M8. Az i-edik dekád napi minimumhőmérsékleteinek átlaga (TMINt_i)

\begin{tabular}{|c|c|c|c|}
\hline KÓD & Indikátor & Intervallum & $\begin{array}{c}\text { intervalluma } \\
\text { (szőkóév) }\end{array}$ \\
\hline TMIN1 & vizsgált év 1. dekádjának napi minimumhőmérsékleteinek átlaga & jan. 1.- jan. 10. & jan. 1.- jan. 10 . \\
\hline TMIN2 & vizsgált év 2. dekádjának napi minimumhőmérsékleteinek átlaga & jan. 11.- jan. 20. & jan. 11.- jan. 20. \\
\hline TMIN3 & vizsgált év 3. dekádjának napi minimumhőmérsékleteinek átlaga & jan. 21.- jan. 30. & jan. 21.- jan. 30. \\
\hline TMIN4 & vizsgált év 4. dekádjának napi minimumhőmérsékleteinek átlaga & jan.31.- febr. 9. & jan.31.- febr. 9. \\
\hline TMIN5 & vizsgált év 5. dekádjának napi minimumhőmérsékleteinek átlaga & febr.10.- febr.19. & febr.10.- febr.19. \\
\hline TMIN6 & vizsgált év 6. dekádjának napi minimumhőmérsékleteinek átlaga & febr.20.- márc. 1. & febr.20.- febr.29. \\
\hline TMIN7 & vizsgált év 7. dekádjának napi minimumhőmérsékleteinek átlaga & márc. 2.- márc. 11. & márc. 1.- márc. 10. \\
\hline TMIN8 & vizsgált év 8. dekádjának napi minimumhőmérsékleteinek átlaga & márc. 12.- márc. 21. & márc. 11.- márc. 20. \\
\hline TMIN9 & vizsgált év 9. dekádjának napi minimumhőmérsékleteinek átlaga & márc. 22.- márc. 31. & márc. 21.- márc. 30. \\
\hline TMIN10 & vizsgált év 10. dekádjának napi minimumhőmérsékleteinek átlaga & ápr. 1. - ápr. 10. & márc. 31. - ápr. 9. \\
\hline TMIN11 & vizsgált év 11. dekádjának napi minimumhőmérsékleteinek átlaga & ápr. 11. - ápr. 20. & ápr. 10. - ápr. 19. \\
\hline TMIN12 & vizsgált év 12. dekádjának napi minimumhőmérsékleteinek átlaga & ápr. 21. - ápr. 30. & ápr. 20. - ápr. 29. \\
\hline TMIN13 & vizsgált év 13. dekádjának napi minimumhőmérsékleteinek átlaga & máj. 1. - máj. 10. & ápr. 30. - máj. 9. \\
\hline TMIN14 & vizsgált év 14. dekádjának napi minimumhőmérsékleteinek átlaga & máj. 11. - máj. 20. & máj. 10. - máj. 19. \\
\hline TMIN15 & vizsgált év 15. dekádjának napi minimumhőmérsékleteinek átlaga & máj. 21. - máj. 30. & máj. 20. - máj. 29. \\
\hline TMIN16 & vizsgált év 16. dekádjának napi minimumhőmérsékleteinek átlaga & máj. 31. - jún. 9. & máj. 30. - jún. 8. \\
\hline TMIN17 & vizsgált év 17. dekádjának napi minimumhőmérsékleteinek átlaga & jún. 10. - jún. 19. & jún. 9. - jún. 18. \\
\hline TMIN18 & vizsgált év 18. dekádjának napi minimumhőmérsékleteinek átlaga & jún. 20. - jún. 29. & jún. 19. - jún. 28. \\
\hline TMIN19 & vizsgált év 19. dekádjának napi minimumhőmérsékleteinek átlaga & jún. 30. - júl. 9. & jún. 29. - júl. 8. \\
\hline TMIN20 & vizsgált év 20. dekádjának napi minimumhőmérsékleteinek átlaga & júl. 10. - júl. 19. & júl. 9. - júl. 18. \\
\hline TMIN21 & vizsgált év 21. dekádjának napi minimumhőmérsékleteinek átlaga & júl. 20. - júl. 29. & júl. 19. - júl. 28. \\
\hline TMIN22 & vizsgált év 22. dekádjának napi minimumhőmérsékleteinek átlaga & júl. 30. -aug. 8 . & júl. 29. -aug. 7. \\
\hline TMIN23 & vizsgált év 23. dekádjának napi minimumhőmérsékleteinek átlaga & aug. 9. - aug. 18. & aug. 8. - aug. 17. \\
\hline TMIN24 & vizsgált év 24. dekádjának napi minimumhőmérsékleteinek átlaga & aug. 19. - aug. 28. & aug. 18. - aug. 27. \\
\hline TMIN25 & vizsgált év 25. dekádjának napi minimumhőmérsékleteinek átlaga & aug. 29. - szept. 7. & aug. 28. - szept. 6. \\
\hline TMIN26 & vizsgált év 26. dekádjának napi minimumhőmérsékleteinek átlaga & szept. 8. - szept. 17. & szept. 7. - szept. 16. \\
\hline TMIN27 & vizsgált év 27. dekádjának napi minimumhőmérsékleteinek átlaga & szept. 18. - szept. 27. & szept. 17. - szept. 26. \\
\hline TMIN28 & vizsgált év 28. dekádjának napi minimumhőmérsékleteinek átlaga & szept. 28. - okt. 7. & szept. 27. - okt. 6. \\
\hline TMIN29 & vizsgált év 29. dekádjának napi minimumhőmérsékleteinek átlaga & okt. 8. - okt. 17. & okt. 7. - okt. 16. \\
\hline TMIN30 & vizsgált év 30. dekádjának napi minimumhőmérsékleteinek átlaga & okt. 18. - okt. 27. & okt. 17. - okt. 26. \\
\hline TMIN31 & vizsgált év 31. dekádjának napi minimumhőmérsékleteinek átlaga & okt. $28 .-$ nov. 6. & okt. 27. - nov. 5. \\
\hline TMIN32 & vizsgált év 32. dekádjának napi minimumhőmérsékleteinek átlaga & nov. 7. - nov. 16. & nov. 6. - nov. 15. \\
\hline TMIN33 & vizsgált év 33. dekádjának napi minimumhőmérsékleteinek átlaga & nov. 17. - nov. 26. & nov. 16. - nov. 25. \\
\hline TMIN34 & vizsgált év 34. dekádjának napi minimumhőmérsékleteinek átlaga & nov. 27. - dec. 6. & nov. 26. - dec. 5. \\
\hline TMIN35 & vizsgált év 35. dekádjának napi minimumhőmérsékleteinek átlaga & dec. 7. - dec. 16. & dec. 6. - dec. 15. \\
\hline TMIN36 & vizsgált év 36. dekádjának napi minimumhőmérsékleteinek átlaga & dec. $17 .-$ dec. 26. & dec. $16 .-$ dec. 25. \\
\hline TMIN37 & vizsgált év 37. dekádjának napi minimumhőmérsékleteinek átlaga & dec. 27. - dec. 31 . & dec. 26. - dec. 31 . \\
\hline ETMIN $i$ & előző év $i$. dekádjának napi minimumhőmérsékleteinek átlaga & & \\
\hline
\end{tabular}


M9. Az i-edik dekád napi maximumhőmérsékleteinek átlaga (TMAXt_i)

\begin{tabular}{|c|c|c|c|}
\hline KÓD & Indikátor & Intervallum & $\begin{array}{c}\text { Intervalluma } \\
\text { (szőkóév) }\end{array}$ \\
\hline TMAX1 & vizsgált év 1. dekádjának napi maximumhőmérsékleteinek átlaga & jan. 1.- jan. 10. & jan. 1.- jan. 10. \\
\hline TMAX2 & vizsgált év 2. dekádjának napi maximumhőmérsékleteinek átlaga & jan. 11.- jan. 20. & jan. 11.- jan. 20. \\
\hline TMAX3 & vizsgált év 3. dekádjának napi maximumhőmérsékleteinek átlaga & jan. 21.- jan. 30. & jan. 21.- jan. 30. \\
\hline TMAX4 & vizsgált év 4. dekádjának napi maximumhőmérsékleteinek átlaga & jan.31.- febr. 9. & jan.31.- febr. 9. \\
\hline TMAX5 & vizsgált év 5. dekádjának napi maximumhőmérsékleteinek átlaga & febr.10.- febr.19. & febr.10.- febr.19. \\
\hline TMAX6 & vizsgált év 6. dekádjának napi maximumhőmérsékleteinek átlaga & febr.20.- márc. 1. & febr.20.- febr.29. \\
\hline TMAX7 & vizsgált év 7. dekádjának napi maximumhőmérsékleteinek átlaga & márc. 2.- márc. 11. & márc. 1.- márc. 10. \\
\hline TMAX8 & vizsgált év 8. dekádjának napi maximumhőmérsékleteinek átlaga & márc. 12.- márc. 21. & márc. 11.- márc. 20. \\
\hline TMAX9 & vizsgált év 9. dekádjának napi maximumhőmérsékleteinek átlaga & márc. 22.- márc. 31. & márc. 21.- márc. 30. \\
\hline TMAX10 & vizsgált év 10. dekádjának napi maximumhőmérsékleteinek átlaga & ápr. 1. - ápr. 10. & márc. 31. - ápr. 9. \\
\hline TMAX11 & vizsgált év 11. dekádjának napi maximumhőmérsékleteinek átlaga & ápr. 11. - ápr. 20. & ápr. 10. - ápr. 19. \\
\hline TMAX12 & vizsgált év 12. dekádjának napi maximumhőmérsékleteinek átlaga & ápr. 21. - ápr. 30. & ápr. 20. - ápr. 29. \\
\hline TMAX13 & vizsgált év 13. dekádjának napi maximumhőmérsékleteinek átlaga & máj. 1. - máj. 10. & ápr. 30. - máj. 9. \\
\hline TMAX14 & vizsgált év 14. dekádjának napi maximumhőmérsékleteinek átlaga & máj. 11. - máj. 20. & máj. 10. - máj. 19. \\
\hline TMAX15 & vizsgált év 15. dekádjának napi maximumhőmérsékleteinek átlaga & máj. 21. - máj. 30. & máj. 20. - máj. 29. \\
\hline TMAX16 & vizsgált év 16. dekádjának napi maximumhőmérsékleteinek átlaga & máj. 31. - jún. 9. & máj. 30. - jún. 8. \\
\hline TMAX17 & vizsgált év 17. dekádjának napi maximumhőmérsékleteinek átlaga & jún. 10. - jún. 19. & jún. 9. - jún. 18. \\
\hline TMAX18 & vizsgált év 18. dekádjának napi maximumhőmérsékleteinek átlaga & jún. 20. - jún. 29. & jún. 19. - jún. 28. \\
\hline TMAX19 & vizsgált év 19. dekádjának napi maximumhőmérsékleteinek átlaga & jún. 30. - júl. 9. & jún. 29. - júl. 8. \\
\hline TMAX20 & vizsgált év 20. dekádjának napi maximumhőmérsékleteinek átlaga & júl. 10. - júl. 19. & júl. 9. - júl. 18. \\
\hline TMAX21 & vizsgált év 21. dekádjának napi maximumhőmérsékleteinek átlaga & júl. 20. - júl. 29. & júl. 19. - júl. 28. \\
\hline TMAX22 & vizsgált év 22. dekádjának napi maximumhőmérsékleteinek átlaga & júl. 30. -aug. 8 . & júl. 29. -aug. 7. \\
\hline TMAX23 & vizsgált év 23. dekádjának napi maximumhőmérsékleteinek átlaga & aug. 9. - aug. 18. & aug. 8. - aug. 17. \\
\hline TMAX24 & vizsgált év 24. dekádjának napi maximumhőmérsékleteinek átlaga & aug. 19. - aug. 28. & aug. 18. - aug. 27. \\
\hline TMAX25 & vizsgált év 25. dekádjának napi maximumhőmérsékleteinek átlaga & aug. 29. - szept. 7. & aug. 28. - szept. 6. \\
\hline TMAX26 & vizsgált év 26. dekádjának napi maximumhőmérsékleteinek átlaga & szept. 8. - szept. 17. & szept. 7. - szept. 16. \\
\hline TMAX27 & vizsgált év 27. dekádjának napi maximumhőmérsékleteinek átlaga & szept. 18. - szept. 27. & szept. 17. - szept. 26. \\
\hline TMAX28 & vizsgált év 28. dekádjának napi maximumhőmérsékleteinek átlaga & szept. 28. - okt. 7. & szept. 27. - okt. 6. \\
\hline TMAX29 & vizsgált év 29. dekádjának napi maximumhőmérsékleteinek átlaga & okt. 8. - okt. 17. & okt. 7. - okt. 16. \\
\hline TMAX30 & vizsgált év 30. dekádjának napi maximumhőmérsékleteinek átlaga & okt. 18. - okt. 27. & okt. 17. - okt. 26. \\
\hline TMAX31 & vizsgált év 31. dekádjának napi maximumhőmérsékleteinek átlaga & okt. 28 . - nov. 6. & okt. 27. - nov. 5. \\
\hline TMAX32 & vizsgált év 32. dekádjának napi maximumhőmérsékleteinek átlaga & nov. 7. - nov. 16. & nov. 6. - nov. 15. \\
\hline TMAX33 & vizsgált év 33. dekádjának napi maximumhőmérsékleteinek átlaga & nov. 17. - nov. 26. & nov. 16. - nov. 25. \\
\hline TMAX34 & vizsgált év 34. dekádjának napi maximumhőmérsékleteinek átlaga & nov. 27. - dec. 6. & nov. 26. - dec. 5 . \\
\hline TMAX35 & vizsgált év 35. dekádjának napi maximumhőmérsékleteinek átlaga & dec. 7. - dec. 16. & dec. $6 .-$ dec. 15. \\
\hline TMAX36 & vizsgált év 36. dekádjának napi maximumhőmérsékleteinek átlaga & dec. 17. - dec. 26. & dec. 16. - dec. 25. \\
\hline TMAX37 & vizsgált év 37. dekádjának napi maximumhőmérsékleteinek átlaga & dec. 27. - dec. 31 & dec. 26. - dec. 31. \\
\hline ETMAXi & dekádjának napi maximumhőmérsékleteinek átlaga & & \\
\hline
\end{tabular}


M10. Az i-edik dekád napi csapadékmennyiségének átlaga (RAINt_i)

\begin{tabular}{|c|c|c|c|}
\hline KÓD & Indikátor & Intervallum & $\begin{array}{c}\text { Intervalluma } \\
\text { (szőkóév) }\end{array}$ \\
\hline RAIN1 & vizsgált év 1. dekádjának napi csapadékmennyiségének átlaga & jan. 1.- jan. 10. & jan. 1.- jan. 10. \\
\hline RAIN2 & vizsgált év 2. dekádjának napi csapadékmennyiségének átlaga & jan. 11.- jan. 20. & jan. 11.- jan. 20. \\
\hline RAIN3 & vizsgált év 3. dekádjának napi csapadékmennyiségének átlaga & jan. 21.- jan. 30. & jan. 21.- jan. 30. \\
\hline RAIN4 & vizsgált év 4. dekádjának napi csapadékmennyiségének átlaga & jan.31.- febr. 9. & jan.31.- febr. 9. \\
\hline RAIN5 & vizsgált év 5. dekádjának napi csapadékmennyiségének átlaga & febr.10.- febr.19. & febr.10.- febr.19. \\
\hline RAIN6 & vizsgált év 6. dekádjának napi csapadékmennyiségének átlaga & febr.20.- márc. 1. & febr.20.- febr.29. \\
\hline RAIN7 & vizsgált év 7. dekádjának napi csapadékmennyiségének átlaga & márc. 2.- márc. 11. & márc. 1.- márc. 10. \\
\hline RAIN8 & vizsgált év 8. dekádjának napi csapadékmennyiségének átlaga & márc. 12.- márc. 21. & márc. 11.- márc. 20. \\
\hline RAIN9 & vizsgált év 9. dekádjának napi csapadékmennyiségének átlaga & márc. 22.- márc. 31. & márc. 21.- márc. 30. \\
\hline RAIN10 & vizsgált év 10. dekádjának napi csapadékmennyiségének átlaga & ápr. 1. - ápr. 10. & márc. 31 . - ápr. 9. \\
\hline RAIN11 & vizsgált év 11. dekádjának napi csapadékmennyiségének átlaga & ápr. 11. - ápr. 20. & ápr. 10. - ápr. 19. \\
\hline RAIN12 & vizsgált év 12. dekádjának napi csapadékmennyiségének átlaga & ápr. 21. - ápr. 30. & ápr. 20. - ápr. 29. \\
\hline RAIN13 & vizsgált év 13. dekádjának napi csapadékmennyiségének átlaga & máj. 1. - máj. 10. & ápr. 30. - máj. 9. \\
\hline RAIN14 & vizsgált év 14. dekádjának napi csapadékmennyiségének átlaga & máj. 11. - máj. 20. & máj. 10. - máj. 19. \\
\hline RAIN15 & vizsgált év 15. dekádjának napi csapadékmennyiségének átlaga & máj. 21. - máj. 30. & máj. 20. - máj. 29. \\
\hline RAIN16 & vizsgált év 16. dekádjának napi csapadékmennyiségének átlaga & máj. 31. - jún. 9. & máj. 30. - jún. 8. \\
\hline RAIN17 & vizsgált év 17. dekádjának napi csapadékmennyiségének átlaga & jún. 10. - jún. 19. & jún. 9. - jún. 18. \\
\hline RAIN18 & vizsgált év 18. dekádjának napi csapadékmennyiségének átlaga & jún. 20. - jún. 29. & jún. 19. - jún. 28. \\
\hline RAIN19 & vizsgált év 19. dekádjának napi csapadékmennyiségének átlaga & jún. 30. - júl. 9. & jún. 29. - júl. 8. \\
\hline RAIN20 & vizsgált év 20. dekádjának napi csapadékmennyiségének átlaga & júl. 10. - júl. 19. & júl. 9. - júl. 18. \\
\hline RAIN21 & vizsgált év 21. dekádjának napi csapadékmennyiségének átlaga & júl. 20. - júl. 29. & júl. 19. - júl. 28. \\
\hline RAIN22 & vizsgált év 22. dekádjának napi csapadékmennyiségének átlaga & júl. 30. -aug. 8 . & júl. 29. -aug. 7. \\
\hline RAIN23 & vizsgált év 23. dekádjának napi csapadékmennyiségének átlaga & aug. 9. - aug. 18. & aug. 8. - aug. 17. \\
\hline RAIN24 & vizsgált év 24. dekádjának napi csapadékmennyiségének átlaga & aug. 19. - aug. 28. & aug. 18. - aug. 27. \\
\hline RAIN25 & vizsgált év 25. dekádjának napi csapadékmennyiségének átlaga & aug. 29. - szept. 7. & aug. 28. - szept. 6. \\
\hline RAIN26 & vizsgált év 26. dekádjának napi csapadékmennyiségének átlaga & szept. 8. - szept. 17. & szept. 7. - szept. 16. \\
\hline RAIN27 & vizsgált év 27. dekádjának napi csapadékmennyiségének átlaga & szept. 18. - szept. 27. & szept. 17. - szept. 26. \\
\hline RAIN28 & vizsgált év 28. dekádjának napi csapadékmennyiségének átlaga & szept. 28. - okt. 7. & szept. 27. - okt. 6. \\
\hline RAIN29 & vizsgált év 29. dekádjának napi csapadékmennyiségének átlaga & okt. 8. - okt. 17. & okt. 7. - okt. 16. \\
\hline RAIN30 & vizsgált év 30. dekádjának napi csapadékmennyiségének átlaga & okt. 18. - okt. 27. & okt. 17. - okt. 26. \\
\hline RAIN31 & vizsgált év 31. dekádjának napi csapadékmennyiségének átlaga & okt. 28 . - nov. 6. & okt. 27. - nov. 5. \\
\hline RAIN32 & vizsgált év 32. dekádjának napi csapadékmennyiségének átlaga & nov. 7. - nov. 16. & nov. 6. - nov. 15. \\
\hline RAIN33 & vizsgált év 33. dekádjának napi csapadékmennyiségének átlaga & nov. 17. - nov. 26. & nov. $16 .-$ nov. 25. \\
\hline RAIN34 & vizsgált év 34. dekádjának napi csapadékmennyiségének átlaga & nov. 27. - dec. 6. & nov. 26. - dec. 5. \\
\hline RAIN35 & vizsgált év 35. dekádjának napi csapadékmennyiségének átlaga & dec. 7. - dec. 16. & dec. 6. - dec. 15. \\
\hline RAIN36 & vizsgált év 36. dekádjának napi csapadékmennyiségének átlaga & dec. 17. - dec. 26. & dec. $16 .-$ dec. 25. \\
\hline RAIN37 & vizsgált év 37. dekádjának napi csapadékmennyiségének átlaga & dec. 27. - dec. 31. & dec. 26. - dec. 31 . \\
\hline ERAIN $i$ & előző év $i$. dekádjának napi csapadékmennyiségének átlaga & & \\
\hline
\end{tabular}


M11. Az i-edik dekád napi minimumhőmérsékleteinek minimuma (TMINNt_i)

\begin{tabular}{|c|c|c|c|}
\hline KÓD & Indikátor & Intervallum & $\begin{array}{c}\text { Intervalluma } \\
\text { (szőkóév) }\end{array}$ \\
\hline TMINN1 & vizsgált év 1. dekádjának napi minimumhőmérsékletének minimuma & Jan. 1.- jan. 10. & jan. 1.- jan. 10. \\
\hline TMINN2 & vizsgált év 2. dekádjának napi minimumhőmérsékletének minimuma & jan. 11.- jan. 20. & jan. 11.- jan. 20. \\
\hline TMINN3 & vizsgált év 3. dekádjának napi minimumhőmérsékletének minimuma & jan. 21.- jan. 30. & jan. 21.- jan. 30. \\
\hline TMINN4 & vizsgált év 4. dekádjának napi minimumhőmérsékletének minimuma & jan.31.- febr. 9. & jan.31.- febr. 9. \\
\hline TMINN5 & vizsgált év 5. dekádjának napi minimumhőmérsékletének minimuma & Febr.10.- febr.19. & febr.10.- febr.19. \\
\hline TMINN6 & vizsgált év 6. dekádjának napi minimumhőmérsékletének minimuma & febr.20.- márc. 1. & febr.20.- febr.29. \\
\hline TMINN7 & vizsgált év 7. dekádjának napi minimumhőmérsékletének minimuma & Márc. 2.- márc. 11. & márc. 1.- márc. 10. \\
\hline TMINN8 & vizsgált év 8. dekádjának napi minimumhőmérsékletének minimuma & márc. 12.- márc. 21. & márc. 11.- márc. 20. \\
\hline TMINN9 & vizsgált év 9. dekádjának napi minimumhőmérsékletének minimuma & márc. 22.- márc. 31. & márc. 21.- márc. 30. \\
\hline TMINN10 & vizsgált év 10. dekádjának napi minimumhőmérsékletének minimuma & ápr. 1. - ápr. 10. & márc. 31. - ápr. 9. \\
\hline TMINN11 & vizsgált év 11. dekádjának napi minimumhőmérsékletének minimuma & ápr. 11. - ápr. 20. & ápr. 10. - ápr. 19. \\
\hline TMINN12 & vizsgált év 12. dekádjának napi minimumhőmérsékletének minimuma & ápr. 21. - ápr. 30. & ápr. 20. - ápr. 29. \\
\hline TMINN13 & vizsgált év 13. dekádjának napi minimumhőmérsékletének minimuma & máj. 1. - máj. 10. & ápr. 30. - máj. 9. \\
\hline TMINN14 & vizsgált év 14. dekádjának napi minimumhőmérsékletének minimuma & máj. 11. - máj. 20. & máj. 10. - máj. 19. \\
\hline TMINN15 & vizsgált év 15. dekádjának napi minimumhőmérsékletének minimuma & máj. 21. - máj. 30. & máj. 20. - máj. 29. \\
\hline TMINN16 & vizsgált év 16. dekádjának napi minimumhőmérsékletének minimuma & máj. 31. - jún. 9. & máj. 30. - jún. 8. \\
\hline TMINN17 & vizsgált év 17. dekádjának napi minimumhőmérsékletének minimuma & jún. 10. - jún. 19. & jún. 9. - jún. 18. \\
\hline TMINN18 & vizsgált év 18. dekádjának napi minimumhőmérsékletének minimuma & jún. 20. - jún. 29. & jún. 19. - jún. 28. \\
\hline TMINN19 & vizsgált év 19. dekádjának napi minimumhőmérsékletének minimuma & jún. $30 .-$ júl. 9. & jún. 29. - júl. 8. \\
\hline TMINN20 & vizsgált év 20. dekádjának napi minimumhőmérsékletének minimuma & júl. 10. - júl. 19. & júl. 9. - júl. 18. \\
\hline TMINN21 & vizsgált év 21. dekádjának napi minimumhőmérsékletének minimuma & júl. 20. - júl. 29. & júl. 19. - júl. 28. \\
\hline TMINN22 & vizsgált év 22. dekádjának napi minimumhőmérsékletének minimuma & júl. 30. -aug. 8. & júl. 29. -aug. 7. \\
\hline TMINN23 & vizsgált év 23. dekádjának napi minimumhőmérsékletének minimuma & aug. 9. - aug. 18. & aug. 8. - aug. 17. \\
\hline TMINN24 & vizsgált év 24. dekádjának napi minimumhőmérsékletének minimuma & aug. 19. - aug. 28. & aug. 18. - aug. 27. \\
\hline TMINN25 & vizsgált év 25. dekádjának napi minimumhőmérsékletének minimuma & aug. 29. - szept. 7. & aug. 28. - szept. 6. \\
\hline TMINN26 & vizsgált év 26. dekádjának napi minimumhőmérsékletének minimuma & szept. 8. - szept. 17. & szept. 7. - szept. 16. \\
\hline TMINN27 & vizsgált év 27. dekádjának napi minimumhőmérsékletének minimuma & szept. 18. - szept. 27. & szept.17. - szept. 26. \\
\hline TMINN28 & vizsgált év 28. dekádjának napi minimumhőmérsékletének minimuma & szept. 28. - okt. 7. & szept. 27. - okt. 6. \\
\hline TMINN29 & vizsgált év 29. dekádjának napi minimumhőmérsékletének minimuma & okt. 8. - okt. 17. & okt. 7. - okt. 16. \\
\hline TMINN30 & vizsgált év 30. dekádjának napi minimumhőmérsékletének minimuma & okt. 18. - okt. 27. & okt. 17. - okt. 26. \\
\hline TMINN31 & vizsgált év 31. dekádjának napi minimumhőmérsékletének minimuma & okt. $28 .-$ nov. 6. & okt. 27. - nov. 5. \\
\hline TMINN32 & vizsgált év 32. dekádjának napi minimumhőmérsékletének minimuma & nov. 7. - nov. 16. & nov. 6. - nov. 15. \\
\hline TMINN33 & vizsgált év 33. dekádjának napi minimumhőmérsékletének minimuma & nov. $17 .-$ nov. 26. & nov. 16. - nov. 25. \\
\hline TMINN34 & vizsgált év 34. dekádjának napi minimumhőmérsékletének minimuma & nov. $27 .-$ dec. 6. & nov. 26. - dec. 5. \\
\hline TMINN35 & vizsgált év 35. dekádjának napi minimumhőmérsékletének minimuma & dec. 7. - dec. 16. & dec. 6. - dec. 15. \\
\hline TMINN36 & vizsgált év 36. dekádjának napi minimumhőmérsékletének minimuma & dec. $17 .-$ dec. 26. & dec. 16. - dec. 25. \\
\hline TMINN37 & vizsgált év 37. dekádjának napi minimumhőmérsékletének minimuma & dec. $27 .-$ dec. 31 & dec. 26. - dec. 31. \\
\hline ETMINNi & Előző év $i$. dekádjának napi minimumhőmérsékletének minimuma & & \\
\hline
\end{tabular}


M12. Az i-edik dekád napi maximumhömérsékleteinek maximuma (TMAXXt_i).

\begin{tabular}{|c|c|c|c|}
\hline KÓD & Indikátor & Intervallum & $\begin{array}{c}\begin{array}{c}\text { Intervalluma } \\
\text { (szőkőév) }\end{array} \\
\end{array}$ \\
\hline TMAXX1 & vizsgált év 1. dekádjának napi maximumhőmérsékletének maximuma & jan. 1.- jan. 10. & jan. 1.- jan. 10 . \\
\hline TMAXX2 & vizsgált év 2. dekádjának napi maximumhőmérsékletének maximuma & jan. 11.- jan. 20. & jan. 11.- jan. 20. \\
\hline TMAXX3 & vizsgált év 3. dekádjának napi maximumhőmérsékletének maximuma & jan. 21.- jan. 30. & jan. 21.- jan. 30. \\
\hline TMAXX4 & vizsgált év 4. dekádjának napi maximumhőmérsékletének maximuma & jan.31.- febr. 9. & jan.31.- febr. 9. \\
\hline TMAXX5 & vizsgált év 5. dekádjának napi maximumhőmérsékletének maximuma & febr.10.- febr.19. & febr.10.- febr.19. \\
\hline TMAXX6 & vizsgált év 6. dekádjának napi maximumhőmérsékletének maximuma & febr.20.- márc. 1. & febr.20.- febr.29. \\
\hline TMAXX7 & vizsgált év 7. dekádjának napi maximumhőmérsékletének maximuma & márc. 2.- márc. 11. & márc. 1.- márc. 10. \\
\hline TMAXX8 & vizsgált év 8. dekádjának napi maximumhőmérsékletének maximuma & márc. 12.- márc. 21. & márc. 11.- márc. 20. \\
\hline TMAXX9 & vizsgált év 9. dekádjának napi maximumhőmérsékletének maximuma & márc. 22.- márc. 31. & márc. 21.- márc. 30. \\
\hline TMAXX10 & vizsgált év 10. dekádjának napi maximumhőmérsékletének maximuma & ápr. 1. - ápr. 10. & márc. 31. - ápr. 9. \\
\hline TMAXX11 & vizsgált év 11. dekádjának napi maximumhőmérsékletének maximuma & ápr. 11. - ápr. 20. & ápr. 10. - ápr. 19. \\
\hline TMAXX12 & vizsgált év 12. dekádjának napi maximumhőmérsékletének maximuma & ápr. 21. - ápr. 30. & ápr. 20. - ápr. 29. \\
\hline TMAXX13 & vizsgált év 13. dekádjának napi maximumhőmérsékletének maximuma & máj. 1. - máj. 10. & ápr. 30. - máj. 9. \\
\hline TMAXX14 & vizsgált év 14. dekádjának napi maximumhőmérsékletének maximuma & máj. 11. - máj. 20. & máj. 10. - máj. 19. \\
\hline TMAXX15 & vizsgált év 15. dekádjának napi maximumhőmérsékletének maximuma & máj. 21. - máj. 30. & máj. 20. - máj. 29. \\
\hline TMAXX16 & vizsgált év 16. dekádjának napi maximumhőmérsékletének maximuma & máj. 31. - jún. 9. & máj. 30. - jún. 8. \\
\hline TMAXX17 & vizsgált év 17. dekádjának napi maximumhőmérsékletének maximuma & jún. 10. - jún. 19. & jún. 9. - jún. 18. \\
\hline TMAXX18 & vizsgált év 18. dekádjának napi maximumhőmérsékletének maximuma & jún. 20. - jún. 29. & jún. 19. - jún. 28. \\
\hline TMAXX19 & vizsgált év 19. dekádjának napi maximumhőmérsékletének maximuma & jún. 30. - júl. 9. & jún. 29. - júl. 8. \\
\hline TMAXX20 & vizsgált év 20. dekádjának napi maximumhőmérsékletének maximuma & júl. 10. - júl. 19. & júl. 9. - júl. 18. \\
\hline TMAXX21 & vizsgált év 21. dekádjának napi maximumhőmérsékletének maximuma & júl. 20. - júl. 29. & júl. 19. - júl. 28. \\
\hline TMAXX22 & vizsgált év 22. dekádjának napi maximumhőmérsékletének maximuma & júl. 30. -aug. 8. & júl. 29. -aug. 7. \\
\hline TMAXX23 & vizsgált év 23. dekádjának napi maximumhőmérsékletének maximuma & aug. 9. - aug. 18. & aug. 8. - aug. 17. \\
\hline TMAXX24 & vizsgált év 24. dekádjának napi maximumhőmérsékletének maximuma & aug. 19. - aug. 28. & aug. 18. - aug. 27. \\
\hline TMAXX25 & vizsgált év 25. dekádjának napi maximumhőmérsékletének maximuma & aug. 29. - szept. 7. & aug. 28. - szept. 6. \\
\hline TMAXX26 & vizsgált év 26. dekádjának napi maximumhőmérsékletének maximuma & szept. 8. - szept. 17. & szept. 7. - szept. 16. \\
\hline TMAXX27 & vizsgált év 27. dekádjának napi maximumhőmérsékletének maximuma & szept. 18.- szept. 27. & szept.17. - szept. 26. \\
\hline TMAXX28 & vizsgált év 28. dekádjának napi maximumhőmérsékletének maximuma & szept. 28 . - okt. 7. & szept. 27. - okt. 6. \\
\hline TMAXX29 & vizsgált év 29. dekádjának napi maximumhőmérsékletének maximuma & okt. $8 .-$ okt. 17. & okt. 7. - okt. 16. \\
\hline TMAXX30 & vizsgált év 30. dekádjának napi maximumhőmérsékletének maximuma & okt. 18. - okt. 27. & okt. 17. - okt. 26. \\
\hline TMAXX31 & vizsgált év 31. dekádjának napi maximumhőmérsékletének maximuma & okt. $28 .-$ nov. 6. & okt. 27. - nov. 5. \\
\hline TMAXX32 & vizsgált év 32. dekádjának napi maximumhőmérsékletének maximuma & nov. 7. - nov. 16. & nov. 6. - nov. 15. \\
\hline TMAXX33 & vizsgált év 33. dekádjának napi maximumhőmérsékletének maximuma & nov. 17. - nov. 26. & nov. $16 .-$ nov. 25. \\
\hline TMAXX34 & vizsgált év 34. dekádjának napi maximumhőmérsékletének maximuma & nov. 27. - dec. 6. & nov. 26. - dec. 5. \\
\hline TMAXX35 & vizsgált év 35. dekádjának napi maximumhőmérsékletének maximuma & dec. $7 .-$ dec. 16 . & dec. 6. - dec. 15. \\
\hline TMAXX36 & vizsgált év 36. dekádjának napi maximumhőmérsékletének maximuma & dec. 17. - dec. 26. & dec. $16 .-$ dec. 25. \\
\hline TMAXX37 & vizsgált év 37. dekádjának napi maximumhőmérsékletének maximuma & dec. 27. - dec. 31. & dec. 26. - dec. 31. \\
\hline ETMAXXi & előző év $i$. dekádjának napi maximumhőmérsékletének maximuma & & \\
\hline
\end{tabular}


M13. A klimatikus indikátorok fajonkénti értékelése

\begin{tabular}{|l|c|c|c|}
\hline \multicolumn{3}{|c|}{ Operophtera. brumata } \\
\hline \multicolumn{2}{|c|}{ klimatikus változása } & egyedszám növekedés \\
\hline & & elösegíti & gátolja \\
\hline $\begin{array}{l}\text { elözö évi márciusi közepi maximumhömérséklet } \\
\text { ETMAXX8 (márc. 12-21.) }\end{array}$ & $\uparrow$ & $*$ & \\
\hline $\begin{array}{l}\text { előző évi augusztus közepi maximumhőmérséklet } \\
\text { ETMAXX23 }\end{array}$ & $\uparrow$ & $*$ & \\
\hline augusztusi csapadék MRAIN8 & $\uparrow$ & & $*$ \\
\hline $\begin{array}{l}\text { előzö évi márciusi közepi hőmérséklet } \\
\text { ETATL8, ETMAX8, ETMIN8 }\end{array}$ & $\uparrow$ & $*$ & \\
\hline
\end{tabular}

\begin{tabular}{|c|c|c|c|}
\hline \multicolumn{4}{|l|}{ Erannis defoliaria } \\
\hline & klimatikus változása & \multicolumn{2}{|c|}{ egyedszám növekedés } \\
\hline & & elősegíti & gátolja \\
\hline októberi minimumhőmérséklet MTMINN10 & $3^{\circ} \mathrm{C}<$ & & * \\
\hline októberi minimumhőmérséklet MTMINN10 & $=<-1^{\circ} \mathrm{C}$ & * & \\
\hline áprilisi minimumhőmérséklet MTMINN4 & $\uparrow$ & $*$ & \\
\hline áprilisi középhőmérséklet TATL11 & $\uparrow$ & $*$ & \\
\hline $\begin{array}{lll}\text { augusztusi } & \text { maximumhömérséklet } & \text { MTMAXX8, } \\
T M A X X 23 & & \end{array}$ & $\uparrow$ & * & \\
\hline december 2. felének csapadéka RAIN36 & $\uparrow$ & & $*$ \\
\hline előző évi márciusi csapadék EMRAIN3 & $\uparrow$ & & * \\
\hline október végi/november eleji csapadék RAIN3I & $\uparrow$ & $*$ & \\
\hline október végi/november eleji csapadék RAIN31 & $3,5 \mathrm{~mm}<$ & $*$ & \\
\hline
\end{tabular}

\begin{tabular}{|c|c|c|c|}
\hline \multicolumn{4}{|l|}{ Colotois pennaria } \\
\hline & klimatikus változása & \multicolumn{2}{|c|}{ egyedszám növekedés } \\
\hline & & elősegíti & gátolja \\
\hline előző évi februári csapadék EMRAIN2, ERAIN6, & $\uparrow$ & $*$ & \\
\hline augusztusi csapadék MRAIN8 & $\uparrow$ & $*$ & \\
\hline $\begin{array}{l}\text { előző és adott évi áprilisi hőmérséklet } \\
E T M A X X 11, T M A X 11,\end{array}$ & $\uparrow$ & * & \\
\hline $\begin{array}{l}\text { előző és adott évi novemberi hőmérséklet } \\
\text { ETMIN11, TMIN32 }\end{array}$ & $\uparrow$ & $*$ & \\
\hline elöző évi decemberi hőmérséklet ETMAXX36 & $\uparrow$ & & $*$ \\
\hline $\begin{array}{l}\text { előző évi október végi - november eleji csapadék } \\
\text { ETMAX31 }\end{array}$ & $\uparrow$ & $*$ & \\
\hline $\begin{array}{l}\text { elöző évi december közepi maximumhőmérséklet } \\
\text { ETMAXX36 }\end{array}$ & $\uparrow$ & & $*$ \\
\hline előző évi augusztus közepi csapadék ERAIN23 & $\uparrow$ & $*$ & \\
\hline
\end{tabular}

\begin{tabular}{|l|c|c|c|}
\hline \multicolumn{5}{|l|}{ Erannis aurantiaria } \\
\hline & klimatikus változása & egyedszám növekedés \\
\hline & & elösegíti & gátolja \\
\hline novemberi csapadék MRAIN11 & $\uparrow$ & & $*$ \\
\hline májusi minimumhőmérséklet MTMIN5, TMIN14 & $\uparrow$ & $*$ & \\
\hline előző évi december végi csapadék ERAIN36 & $\uparrow$ & $*$ & \\
\hline
\end{tabular}




\begin{tabular}{|l|c|c|c|}
\hline \multicolumn{5}{|l|}{ Idaea dimidiata } \\
\hline \multicolumn{2}{|c|}{ klimatikus változása } & \multicolumn{2}{c|}{ egyedszám növekedés } \\
\hline & & elösegíti & gátolja \\
\hline március végi csapadék RAIN9, MRAIN3 & $\uparrow$ & $*$ & \\
\hline márciusi csapadék & $\uparrow \uparrow$ & & $*$ \\
\hline szeptember közepi csapadék ERAIN26 & $\uparrow$ & $*$ & \\
\hline $\begin{array}{l}\text { előzó áprilisi minimumhómérséklet ETMIN11, } \\
\text { EMTMIN4 }\end{array}$ & $\uparrow$ & $*$ & \\
\hline $\begin{array}{l}\text { előző évi október végi - november eleji } \\
\text { maximumhőmérséklet ETMAX31 }\end{array}$ & $\uparrow$ & $*$ & \\
\hline előző évi júniusi végi minimumhőmérséklet ETMIN18 & $\uparrow$ & & $*$ \\
\hline elöző évi január eleji minimumhömérséklet ETMINN1 & $\uparrow$ & & $*$ \\
\hline
\end{tabular}

\begin{tabular}{|l|c|c|c|}
\hline \multicolumn{3}{|l|}{ Scopula nigropunctata } \\
\hline & klimatikus változása & \multicolumn{2}{c|}{ egyedszám növekedés } \\
\hline & & elősegíti & gátolja \\
\hline februári végi csapadék RAIN6 & $\uparrow$ & & $*$ \\
\hline előző évi júniusi minimumhőmérséklet ETMIN18 & $\uparrow$ & & $*$ \\
\hline $\begin{array}{l}\text { előző évi szeptember eleji minimumhőmérséklet } \\
\text { ETMIN25 }\end{array}$ & $\uparrow$ & & $*$ \\
\hline $\begin{array}{l}\text { előző évi november első feli minimumhőmérséklet } \\
\text { ETMIN32 }\end{array}$ & $\uparrow$ & & $*$ \\
\hline
\end{tabular}

\begin{tabular}{|c|c|c|c|}
\hline \multicolumn{4}{|l|}{ Pelurga comitata } \\
\hline & klimatikus változása & \multicolumn{2}{|c|}{ egyedszám növekedés } \\
\hline & & elösegíti & gátolja \\
\hline áprilisi csapadék MRAIN4 & 个个 & & $*$ \\
\hline áprilisi csapadék MRAIN4 & $\uparrow$ & $*$ & \\
\hline $\begin{array}{l}\text { előző évi április közepi minimumhőmérséklet } \\
\text { ETMIN11 }\end{array}$ & $\uparrow$ & & $*$ \\
\hline $\begin{array}{lcc}\text { elözö évi } & \text { augusztusi } & \text { maximumhőmérséklet } \\
\text { ETMAXX23 } & & \\
\end{array}$ & 个 & & $*$ \\
\hline előző évi július közepi csapadék ERAIN2O & $\uparrow$ & & $*$ \\
\hline elöző évi augusztusi csapadék ERAIN24 & $\mathbf{0}$ & & $*$ \\
\hline áprilisi hőmérséklet MTATL4, TMINI2, & $\uparrow$ & $\neq$ & \\
\hline január végi minimumhömérséklet ERAIN3 & $\uparrow$ & & $*$ \\
\hline március végi minimumhőmérséklet TMINN8 & $\uparrow$ & & $\not \neq$ \\
\hline előző évi július végi minimumhőmérséklet ETMINN21 & 个 & $*$ & \\
\hline
\end{tabular}

\begin{tabular}{|c|c|c|c|}
\hline \multicolumn{4}{|l|}{ Eulithis pyraliata } \\
\hline & klimatikus változása & \multicolumn{2}{|c|}{ egyedszám növekedés } \\
\hline & & elősegíti & gátolja \\
\hline előző évi január végi csapadék ERAIN3 & 个 & $*$ & \\
\hline előzö évi március végi csapadék ERAIN9 & $\uparrow$ & * & \\
\hline $\begin{array}{l}\text { elözö évi november végi - december eleji csapadék } \\
\text { ERAIN34, RAIN35 }\end{array}$ & 个 & $*$ & \\
\hline áprillisi csapadék MRAIN4 & $\downarrow$ & $*$ & \\
\hline áprilisi minimumhőmérséklet MTMIN4 & $\downarrow$ & $*$ & \\
\hline $\begin{array}{l}\text { elözö tavaszi maximumhömérséklet } \\
\text { ETMAXX12, TMAXX15 }\end{array}$ & $\uparrow$ & & $*$ \\
\hline szeptemberi öszi minimumhőmérséklet TMINN25 & $\uparrow$ & & $*$ \\
\hline
\end{tabular}

